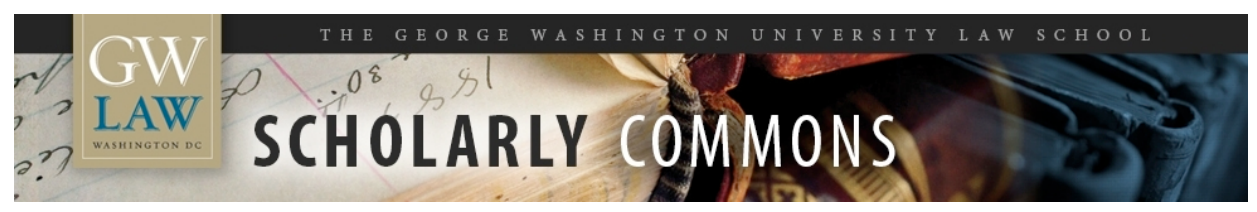

\title{
Subsidiarity and Self-Interest: Federalism at the European Court of Justice
}

\section{Edward T. Swaine}

George Washington University Law School, eswaine@law.gwu.edu

Follow this and additional works at: https://scholarship.law.gwu.edu/faculty_publications

Part of the Law Commons

\section{Recommended Citation}

Harvard International Law Journal, Vol. 41, No. 1, Winter 2000

This Article is brought to you for free and open access by the Faculty Scholarship at Scholarly Commons. It has been accepted for inclusion in GW Law Faculty Publications \& Other Works by an authorized administrator of Scholarly Commons. For more information, please contact spagel@law.gwu.edu. 
Volume 41, Number 1, Winter 2000

\title{
Subsidiarity and Self-Interest: Federalism at the European Court of Justice
}

\author{
Edward T. Swaine*
}

\section{INTRODUCTION}

The problems of federalism are both profound and urgently practical. No one is entirely sure what the term "federalism" means, ${ }^{1}$ or why it is desirable. ${ }^{2}$ Almost everyone, however, appreciates the

* Assistant Professor of Legal Studies, The Wharton School, University of Pennsylvania. A.B., Harvard, 1985; J.D., Yale, 1989. Research for this Article was begun at the Centre for Advanced Legal Studies at the Katholieke Universiteit Leuven, and I would like to thank staffs at the C.A.L.S. and the University of Pennsylvania Law School for their assistance. I received valuable comments at a Wharton faculty workshop, and from Richard Shell and Eric Orts on an earlier draft.

1. See Ivo D. Duchacek, Comparative Federalism: An Agenda for Additional Research, in Constitutional Design and Power-Sharing in the Post-Modern Epoch 23 (Daniel J. Elazar ed., 1991) (noting that "students of federalism remain severely handicapped in their search for explanations by their failure to agree on what federalism is"); see also Frederick K. Lister, The European Union, the United Nations, and the Revival of Confederal Governance 19 (1996) (observing that the estimated number of federal systems ranges from 4 to 44); Ingolf Pernice, Harmonization of Legislation in Federal Systems: Constitutional, Federal, and Subsidiarity Aspects, in Harmonization of Legislation in Federal Systems: Constitutional, Federal and Subsidiarity Aspects-The European Union and the United States of Amerika Compared 13 (Ingolf Pernice ed., 1996) (noting that as of 1984, some 497 different adjectives had already been employed before the term "federalism" in the scholarly liter ature).

This Article employs the term broadly to facilitate comparison. See Koen Lenaerts, Constitutionalism and the Many Faces of Federalism, 38 Am. J. Comp. L. 205, 263 (1990) ("Federalism is present whenever a divided sovereign is guaranteed by a national or supranational constitution and umpired by the supreme court of the common legal order."); see also Koen Lenaerts, Federalism: Essential Concepts in Evolution-The Case of the European Union, 21 Fordham Int'l L.J. 746, 747-52 (1998); Larry Kramer, Understanding Federalism, 47 Vand. L. Rev. 1485, 1488 n.5 (1994).

2. See David L. Shapiro, Federalism: A Dialogue 34-58 (1995) (summarizing case to be made for strong national authority); $i d$. at $75-106$ (case for preserving state authority); Barry Friedman, Valuing Federalism, 82 Minn. L. Rev. 317, 378-412 (1997); see also Gerald L. Neuman, Subsidiarity, Harmonization, and Their Values: Convergence and Divergence in Europe and the United States, 2 Colum. J. Eur. L. 573, 574-76 (1996) (distinguishing between virtues of federalism in U.S. and European contexts). Compare, e.g., George A. Bermann, Taking Subsidiarity Seriously: Federalism in the European Community and the United States, 94 Colum. L. Rev. 331, 339-43 (1994) (summarizing values potentially promoted by subsidiarity), and Robert P. Inman \& David L. Rubinfeld, Subsidiarity and the European Union 2-13 (NBER Working Paper 6556, May 1998) (same), and Kramer, supra note 1, with 
risks involved when a central government accretes power, or when local governments refuse to enforce federal law-commonly, when the law applies to the rights of individuals against those governments themselves.

The profound and practical dimensions of federalism are closely interwoven in the European Community. ${ }^{3}$ This interplay of power between the Community and its Member States, as George Bermann observed, has "fostered a remarkable renewal of interest in the problems of American federalism." 4 The American problem, however, lies in developing meaningful and stable safeguards against encroachment by the federal government. ${ }^{5}$ For the Community, on the other hand, the relative absence of an independent federal check on Member States raises the question of whether it can be described as a federal system in the ${ }^{a}$ rst place. ${ }^{6}$ Revealingly,

A.E. Dick Howard, The Values of Federalism, 1 New Eur. L. Rev. 143, 156-60 (1993) (noting drawbacks to localism), and Edward L. Rubin \& Malcolm Feeley, Federalism: Some Notes on a National Neurosis, 41 UCLA L. Rev. 903 (1994) (questioning U.S. pursuit of federalism), and Edward L. Rubin, Henry J. Miller Lecture Series and Symposium: "New Frontiers of Federalism": The Fundamentality and Irrelevance of Federalism, 13 Ga. St. U. L. Rev. 1009, 1009 (1997) (same).

3. In keeping with the prevailing practice and the ordinary scope of the Court of Justice's jurisdiction, this Article will refer to "Community" or "EC" law, rather than "European Union" or "EU" law, notwithstanding the formation of the European Union in 1992. The Court of Justice, for its part, continues to be known as the Court of Justice of the European Communities.

4. George A. Bermann, European Community Law from a U.S. Perspective, 4 Tul. J. Int'l \& Comp. L. 1, 5 (1995); for a small sample, see, for example, Paul Dubinsky, The Essential Function of Federal Courts: The European Union and the United States Compared, $42 \mathrm{Am}$. J. Comp. L. 295 (1994); Denis J. Edwards, Fearing Federalism's Failure: Subsidiarity in the European Union, 44 Am. J. Comp. L. 537 (1996); Barry Friedman, Federalism's Future in the Global Village, 47 Vand. L. Rev. 1441 (1994); Lord Mackenzie-Stuart, Problems of the European Community -Transatlantic Parallels, 36 Int'l \& Comp. L.Q. 183 (1987); G. Fredrico Mancini, The Making of a Constitution for Europe, 26 Common Mkt. L. Rev. 595, 595-96 (1989); Pernice, supra note 1, at 17, 19; Eric Stein, On Divided-Power Systems: Adventures in Comparative Law, 1983/1 Legal Issues of Eur. Integration 27 (1983); W. Gary Vause, The Subsidiarity Principle in European Union Law-American Federalism Compared, 27 Case W. Res. J. Int'1 L. 61 (1995). The way was forged by 1-3 Mauro Cappelletti et al., Integration Through Law: Europe and the American Federal Experience (1985-1988).

5. See Garcia v. San Antonio Metro. Transit Auth., 469 U.S. 528 (1985) (overruling National League of Cities v. Usery, 426 U.S. 833 (1976) (overruling Maryland v. Wirtz, 392 U.S. $183(1968)))$.

6. See, e.g., Diarmuid Rossa Phelan, Revolt or Revolution: The Constitutional Boundaries of the European Community 160-62 (1997) (citing characteristics of European legal federalism); Jacques Pelkmans, Governing European Union: From Pre-Federal to Federal Economic Integration?, in Rethinking Federalism: Citizens, Markets, and Governments in a Changing World (Karen Knopp, et al. eds., 1995) (concluding that "[t]he present European Union is still only half-way along the path to federalism"); Thomas C. Fischer \& Stephen C. Neff, Some American Thoughts About European "Federalism", 44 Int'l \& Comp. L.Q. 904, 905-06 (1995); Lenaerts, Federalism: Essential Concepts, supra note 1, at 746-51 (concluding that "the essential aspect of federalism, namely the balance of sovereignty between the central authority and the component entities, may be said to be present"); Thomas Merrill, A New Age of Federalism?, 1 Green Bag 2d 153, 154 (1998) (concluding that "impartial observers" would agree that Community "is at least headed [toward federalism]"); see 
while the American notion of federalism is often associated with states' rights, European critics not infrequently use the " $F$ " word to connote centralization. ${ }^{7}$

This contrast is apparent in the Community's approach to the practical problem of applying federal law against Member States. Much like in the United States, the European Court of Justice has generally held that Member States charged with enforcing Community law may determine their own rules, so long as they do not defeat or discriminate against Community rights. ${ }^{8}$ But the European approach diverges from the American approach when it comes to punishing Member States for the breach of Community rules. Following its seminal decision in Francovich v. Italy, ${ }^{9}$ the Court has held Member States liable for breaching Community law in a variety of circumstances-most notably, for their failure to implement directives ${ }^{10}$ when that failure allows one private party to commit wrongs against another. ${ }^{11}$ Francovich is widely celebrated for hav-

also Deborah Z. Cass, The Word That Saves Maastricht? The Principle of Subsidiarity and the Division of Powers within the European Community, 29 Common Mkt. L. Rev. 1107, 1109 \& nn.3, 5 (1992) (surveying diverse views). As Professor Hartley has observed, the most compelling argument is the fact that " $[\mathrm{t}] \mathrm{he}$ decisions of the Community derive their binding force from the fact that they are taken by organs endowed with the appropriate power by the Treaties - the constitution of the Community - and not because they have been agreed to by Member States." T.C. Hartley, The Foundations of European Community Law 10 (4th ed. 1994).

7. Drafters of the Maastricht Treaty were forced to avoid what was dubbed the "F" word because of persistent disagreement between the British, who thought the term connoted greater centralization, and those on the continent, who felt to the contrary. See Pernice, supra note 1, at 22; T. Koopmans, Federalism: The Wrong Debate, 29 Common Mkt. L. Rev. 1047 (1992); see also Fischer \& Neff, supra note 6 (addressing British objections). Maastricht did not end the dispute. The Bundesverfassungsgericht Germany's constitutional court, $₫$ scribed the Community as a union of states, or confederation, rather than a federation, in af ${ }^{a}$ rming the legality of the Maastricht Treaty. See Case 2BvR 2134/92 \& 2159/92, Brunner v. European Union Treaty (The Maastricht Decision), [1994] 1 C.M.L.R. 57, 89-91 (1994).

8. See Case 33/76, Rewe-Zentral- ${ }^{a}$ nanz eG v. Landwirtschaftskammer für das Saarland, 1976 E.C.R. 1989, [1977] 1 C.M.L.R. 533 (1976) [hereinafter Rewe-Zentral-"anan; see also Howlett v. Rose, 496 U.S. 356, 369-74 (1990); FERC v. Mississippi, 456 U.S. 742, 776 n.1 (1982) (O'Connor, J., dissenting).

9. Cases C-6/90 \& C-9/90, Francovich v. Italy, 1991 E.C.R. I-5357, [1993] 2 C.M.L.R. 66 (1991) [hereinafter Francovich].

10. See Treaty Establishing the European Community, art. 249 (ex art. 189), Nov. 10, 1997, O.J. (C 340) 173 (1997) [hereinafter EC Treaty] (describing Community forms of legislation). For purposes of this Article, references to the EC Treaty should also be taken to include the predecessor EEC Treaty, as amended by the Single European Act, unless otherwise indicated. Treaty Establishing the European Economic Community, Mar. 25, 1957, 298 U.N.T.S. 11, 1973 Gr. Brit. T.S. No. 1 (Cmd. 5179-II), as amended by Single European Act, 1987 O.J. (L 169) 1, [1987] 2 C.M.L.R. 741 (1987), in Treaties Establishing the European Communities (EC Off'l Pub. Off. 1987).

11. The liability rule initially declared in Francovich has been applied to the adoption by Member States of legislation inconsistent with the Treaty, and the failure to amend legislation previously deemed inconsistent, see Case C-302/97, Konle v. Republic of Austria 1999 ECJ CELEX LEXIS 1924 (Eur. Ct. Justice, June 1, 1999); Cases C-46/93 \& C-48/93, Brasserie du Pêcheur SA v. Federal Republic of Germany and Regina v. Secretary of State for Transport, ex parte Factortame Ltd., 1996 E.C.R. I-1029, [1996] 1 C.M.L.R. 889 (1996) [hereinafter 
ing made strides toward a European federalism founded on the vindication of individual rights. ${ }^{12}$ Increasingly it can be said that for every Community right there is a remedy, but only against Member States.

Brasserie du Pêcheur, or Factortame III, as relevant]; the refusal by a government minister to take administrative action required by the Treaty, see Case C-5/94, Regina v. Ministry of Agriculture, Fisheries and Foreign Affairs, ex parte Hedley Lomas (Ireland) Ltd., 1996 E.C.R. I-2553, [1996] 2 C.M.L.R. 391 (1996) [hereinafter Hedley Lomas]; the incorrect implementation into domestic law of a Community directive, see Case C-140/97, Rechberger v. Republic of Austria, 1999 ECJ CELEX LEXIS 1882 (Eur. Ct. Justice, June 15, 1999); Case C-319/96, Brinkmann Tabakfabriken v. Skatteministeriet, [1998] 3 C.M.L.R. 673; Case C-127/95, Norbrook Laboratories Ltd. v. Ministry of Agriculture, Fisheries of Food, 1998 E.C.R. I-1531, [1998] 3 C.M.L.R. 809 (1998); Case C-2/94, Denkavit Internationaal BV v. Kamer Van Koophandel En Fabrieken Voor Middengelderland, 1996 E.C.R. I-5063, [1996] 3 C.M.L.R. 504 (1996); Case C-66/95, Regina v. Secretary of State for Social Security, ex parte Sutton, 1997 E.C.R. I-2163, [1997] 2 C.M.L.R. 382 (1997); Case C-392/93, Regina v. H.M. Treasury ex parte British Telecommunications PLC, 1996 E.C.R. I-1631, [1996] 2 C.M.L.R. 217 (1996); Case C-334/92, Miret v. Fondo de Garatin Salarial, 1993 E.C.R. I6911, [1995] 2 C.M.L.R. 49 (1993); the failure to implement, or belated implementation of, a directive, see Cases C-178-179 \& C-188-190/94, Dillenkofer v. Germany, 1996 E.C.R. I4845, [1996] 3 C.M.L.R. 469 (1996); and the belated implementation of a directive combined, potentially, with liability for failure properly to implement, see Case C-373/95, Maso v. Instituto Nazionale Della Prevedenza Sociale (INPS) \& Italy, 1997 E.C.R. I-4051, [1997] 3 C.M.L.R. 1244 (1997); Case C-261/95, Palmisani v. INPS, 1997 E.C.R. I-4025, [1997] 3 C.M.L.R. 1356 (1997); Case C-94-95/95, Bonifaci v. INPS, 1997 E.C.R. I-3969, [1998] 1 C.M.L.R. 257 (1997). The Court has also suggested the alternative remedy of state liability in a number of cases raising other issues. See Case C-111/97, EvoBus Austria GmbH v. Niederosterreichische Verkehrsorganisations GmbH (Novog), 1998 ECJ CELEX LEXIS 6434, II 21 (Eur. Ct. Justice, Sept. 24, 1998) (in the event that national law cannot be interpreted so as to conform with Community law, state may be liable); Cases C-192/95 to C218/95, Société Comateb v. Directeur Général des Douanes et Droits Indirect, 1997 E.C.R. I165, II 34, [1997] 2 C.M.L.R. 649, II 34 (1997) (traders prevented from recovering charges levied contrary to Community law may recover on state liability grounds); Case C-242/95, GT-Link A/S v. Danske Statsbaner DSB, 1997 E.C.R. I-4449, II 60 [1997] 5 C.M.L.R. 601, II 60 (1997) (same); Case C-90/96, Petrie v. Università degli studi di Verona, [1998] 1 C.M.L.R. 711 (although foreign language assistants could not be barred by nationality equirements from participating in competitions for tenured posts, they must meet other eligibility requirements, and may in any event seek compensation for injury in accord with state liability principles); Case C-97/96, Daihatsu Verband deutscher Daihatsu-Handler eV v. Daihatsu Deutschland GmbH, 1997 E.C.R. I-6843, II 25 (although failure to implement drective properly does not give rise to liability between private parties, party suffering injury may seek compensation from state).

12. See, e.g., Koen Lenaerts, Federalism and Rights in the European Community, in Federalism and Rights 139, 146-47 (Ellis Katz \& G. Alan Tarr eds., 1996). The rule could also be explained, however, as consistent with the Community's identity as a supra-national organization, given the principle of state responsibility's roots in international law. See Denis F. Waelbroeck, Treaty Violations and Liability of Member States and the European Community: Convergence or Divergence?, in 2 Institutional Dynamics of European Integration: Essays in Honour of Henry G. Schermers 467 \& n.19 (Deirdre Curtin \& Ton Heukels eds., 1994) (citing Chorzów Factory (Ger. v. Pol.), 1928 P.C.I.J. (ser. A) No. 17 (Sept. 13), pp. 46-48); Opinion of Advocate General Tesauro, Joined Cases C-46/93 \& C-48/93, Brasserie du Pêcheur, 1996 E.C.R. I-1029, I[ 38, [1996] 1 C.M.L.R. 889, II 38 (1996); cf. Philip Allott, State Responsibility and the Unmaking of International Law, 29 Harv. Int'l L.J. 1 (1988) (lamenting absence of progress in de $\mathrm{a}^{\mathrm{n}}$ ing binding rights and obligations of international law). 
This principle of individual rights stands in stark contrast to the strongest vestiges of U.S. constitutional federalism, including the doctrines barring federal commandeering ${ }^{13}$ and protecting state sovereign immunity. ${ }^{14}$ It also seems to be on a collision course with subsidiarity, a Community constitutional principle of new and potentially enormous signi ${ }^{a}$ cance. ${ }^{15}$ Codia $^{a}$ in the Maastricht Treaty shortly after Francovich was decided, subsidiarity requires Community institutions to defer to Member States unless a Community action is demonstrably superior-or, to quote Article 5 (ex art. 3b), "only if and insofar as the objectives of the proposed action cannot be sufaciently achieved by Member States and can[,] therefore, by reason of the scale or effects of the proposed action, be better achieved by the Community." " Subsidiarity is a critical reaction not only to the gradual shift in legislative authority from the Member States-dominated Council to more autonomous Community institutions, ${ }^{17}$ but also to the Court of Justice's expansive interpretation of

13. See New York v. United States, 505 U.S. 144 (1992) (holding that "take title" provisions of Low-Level Radioactive Waste Policy Amendments Act of 1985 unconstitutionally require states either to legislate pursuant to congressional direction or to implement administrative solutions); see also Printz v. United States, 521 U.S. 898 (1997) (holding that interim provisions of Brady Act requiring local law enforcement of ${ }^{a}$ cers to conduct background checks violate constitutional principle of "dual sovereignty"). Justice Breyer's dissent in Printz invoked Community directives in arguing in favor of permitting Congressional direction of state and local of ${ }^{\mathrm{a}}$ cials (though he tactfully omitted mention of Francovich liability). Printz, 521 U.S. at 976-77 (Breyer, J., dissenting). Justice Scalia, for the majority, would have none of it: "[w]e think such comparative analysis inappropriate ... . The fact is that our federalism is not Europe's." 521 U.S. at 921 n.11.

14. See Richard B. Stewart, Environmental Law in the United States and the European Community: Spillovers, Cooperation, Rivalry, Institutions, 1992 U. Chi. L. Forum 41, 72; see, e.g., Seminole Tribe of Florida v. Florida, 517 U.S. 44 (1996) (overruling Pennsylvania v. Union Gas, 491 U.S. 1 (1989), in holding that Congress may not abrogate state immunity when legislating pursuant to Indian Commerce Clause).

15. See Speech by Sir Leon Brittan, Vice-President of the European Communities, Subsidiarity in the Constitution of the European Community, Robert Schuman Lecture, European University Institute, June 11, 1992, in Europe Doc. No. 1786 ("I predict that Article 3b of the Treaty"-incorporating subsidiarity-"will prove to be one of the most important modia ${ }^{a}$ cations to the Community's constitution since 1957."); cf. Bermann, supra note 2, at 332 (noting that subsidiarity principle has "dominated discussions of European federalism for over " ve years").

16. EC Treaty art. 5 (ex art. 3b). Subsidiarity was originally incorporated in Article 3b of the EC Treaty following Maastricht, but following ratia cation of the Amsterdam Treaty in 1999 was renumbered as Article 5. For ease of reference, I will refer to the post-Amsterdam numbering scheme throughout, but indicate the former number of Treaty provisions as appropriate (e.g., "Article 5 (ex art. 3b)"). The Amsterdam Treaty also clariaed the meaning of subsidiarity and proportionality principles via an important protocol. See Protocol on the Application of the Principles of Subsidiarity and Proportionality, Treaty of Amsterdam amending the Treaty on European Union, the Treaties establishing the European Communities and certain related acts, 1997 O.J. (C 340) 1 [hereinafter Amsterdam Protocol and Amsterdam Treaty, as appropriate]. In 1998, a prominent British supporter of the EU called for a new treaty centered on the subsidiarity principle to further protect the sovereignty of Member States. See Patrick Hennessy, Hurd Calls for New EU Treaty to Protect the Nation State, Evening Standard (London), June 17, 1998, at 19.

17. In particular, through the development of qualiaed-majority voting and a role for the 
Community powers against the apparent interest of Member States. ${ }^{18}$ Subsidiarity thus seems akin to American concerns about limiting federal intervention ${ }^{19}$ and, as such, attracts keen interest on this side of the Atlantic as well. ${ }^{20}$

The question I wish to address is this: in light of subsidiarity, how can the state liability principle announced in Francovich remain standing? Scholars have addressed both subsidiarity and state liability at great length. ${ }^{21}$ But while many have asked whether compliance by the Community's legislative institutions with subsidiarity is subject to judicial review, ${ }^{22}$ few have considered subsidiarity's

European Parliament. See Koen Lenaerts, The Principle of Subsidiarity and the Environment in the European Union: Keeping the Balance of Federalism, 17 Fordham Int'l L.J. 846, 84651 (1994).

18. See, e.g., Bermann, supra note 2, at 400-03; George A. Bermann, Subsidiarity and the European Community, 17 Hastings Int'l \& Comp. L. Rev. 97, 101-03 (1993); Ian Ward, The Best of All Possible Worlds? Maastricht and the United Kingdom, 5 Ind. Int'l \& Comp. L.J. 75, 92-96 (1994). The degree to which the Court is genuinely independent of Member State preferences is a matter of dispute. But according to Professors Keohane and Hoffmann, "of all Community institutions, the Court has gone farthest in limiting national autonomy, by asserting the principles of superiority of Community law and of the obligation of member states to implement binding national acts consistent with Community directives.” Robert O. Keohane \& Stanley Hoffmann, Institutional Change in Europe in the 1980s in The New European Community: Decisionmaking and Institutional Change 1, 11-12 (Robert O. Keohane \& Stanley Hoffmann eds., 1991).

19. Most scholars consider subsidiarity more appropriate to a nascent than to a developed federalism. See Bermann, supra note 2, at 456 (concluding that subsidiarity seems a comparatively "crude" approach to federalism, but one appropriate "for a polity that is still seeking to establish its basic federal-state equilibrium, rather than merely to preserve it"); see also George A. Bermann, Subsidiarity as a Principle of U.S. Constitutional Law, 42 Am. J. Comp. L. 555 (supp. 1994); David P. Currie, Subsidiarity, 1 Green Bag 2d 359, 360 (1998) ("Subsidiarity, in short, was an American principle long before either the European Community or the Federal Republic of Germany was established."); Lord Mackenzie-Stuart, Assessment of the Views Expressed and Introduction to a Panel Discussion, in Subsidiarity: The Challenge of Change 38 (European Inst. of Pub. Admin., Proceedings of the Jacques Delors Colloquium, 1991) (citing practices of colonial America, and framing of U.S. Constitution, as true precedent for European subsidiarity). But see Stephen Gardbaum, Rethinking Constitutional Federalism, 74 Tex. L. Rev. 795, 831-36 (1996) (arguing that congressional power of preemption and power to regulate local activities, if properly rooted in Necessary and Proper Clause, must be justia ed in subsidiarity-like analysis).

20. See, e.g., Clayton P. Gillette, The Exercise of Trumps by Decentralized Governments, 83 Va. L. Rev. 1347, 1367-69 (1997); Richard L. Revesz, Federalism and Environmental Regulation: Lessons for the European Union and the International Community, 83 Va. L. Rev. 1331, 1340-41 (1997).

21. Francovich "has been the subject of so much comment as to require apology for any more." Carol Harlow, Francovich and the Problem of the Disobedient State, 2 Eur. L.J. 199, 199 (1996); see also Roberto Caranta, Judicial Protection Against Member States: A New Jus Commune Takes Shape, 32 Common Mkt. L. Rev. 703, 709 (1995) (noting that Francovich "has spurred a massive literature almost without precedent"). Subsidiarity has kept pace. See Gráinne de Búrca, The Principle of Subsidiarity and the Court of Justice as an Institutional Actor, 36 J. Common Mkt. Stud. 217, 218 (1998). The reproductive effects of combining these phenomena are beyond the scope of this Art icle.

22. See, e.g., Bermann, supra note 2, at 390-95; Daniel G. Partan, The Justiciability of Subsidiarity, in The State of the European Union: Building a European Polity? ch. 3 (Carolyn Rhodes \& Sonia Mazey eds., 1995); A.G. Toth, Is Subsidiarity Justiciable?, 19 Eur. L. Rev. 268 (1994). The British Government presented a memorandum to the 1996 intergovernmen- 
relevance to the Court of Justice's jurisprudence, let alone its application to Francovich. ${ }^{23}$ George Bermann has suggested that subsidiarity may not be applicable at all to settled constitutional principles, ${ }^{24}$ and certainly many would consider Francovich, which I use to signify both the original judgment and its progeny, to be among those principles. ${ }^{25}$ Gráinne de Búrca suggests that the Court's decisions may require closer scrutiny for their consistency with subsid iarity, but she does not suggest that it is obligatory, nor elaborate on how it might be applied. ${ }^{26}$ Finally, some scholars suggest that if subsidiarity were to apply to judicial decision-making, Francovich would not survive - calling the relevance of subsidiarity to the judiciary, ${ }^{27}$ or the authority of Francovich, ${ }^{28}$ into doubt.

tal conference urging that the Court of Justice be expressly tasked with applying subsidiarity in interpreting Community legislation. See The European Court of Justice, Memorandum by the United Kingdom for the Inter-Governmental Conference (July 1996), <http://europa.eu.int/en/agenda/ igc-home/ms-doc/state-uk/courtjus.htm> [hereinafter U.K. Memorandum]. But the proposal was not incorporated in the Amsterdam Treaty. See The Treaty of Amsterdam: Text and Commentary 104 (Andrew Duff ed., 1997); Karen J. Alter, Who Are the "Masters of the Treaty"?: European Governments and the Court of Justice, 52 Int'l Org 120, 140-41 (1998).

23. See de Búrca, supra note 21, at 220 ("Despite the fact that so much has been written about subsidiarity, the discussion has been almost exclusively in relation to its possible impact upon the conduct of the political institutions. Apart from considering its use by the Court in reviewing the other institutions, the debate has only rarely touched upon the impact of subsidiarity on the Court's exercise of its own powers."); see, e.g., Lenaerts, supra note 12, at 146 (suggesting, following discussion of the Court and its protection of rights in a federal system, that the political process may ${ }^{a}$ nd the appropriate balance via Article 5 (ex art. 3b)) cf. Jason Coppel, Rights, Duties and the End of Marshall, 57 Mod. L. Rev. 859, 876 (1994) (raising, and rejecting, argument that extending horizontal direct effect to directives might, by assimilating directives to regulations, con ${ }^{\circ}$ ict with subsidiarity); Opinion of Advocate General Jacobs, Case C-430 \& C-431/93, van Schijndel v. Stichting Pensioenfonds voor Fysiotherapeuten, 1995 E.C.R. I-4705, 4715-16, [1996] 1 C.M.L.R. 801 (1995) [hereinafter van Schinjndel] (were national procedural rules always to yield to Community law, "[i]t could be regarded as infringing the principle of proportionality and, in a broad sense, the principle of subsidiarity ...”).

24. See Bermann, supra note 2, at 402.

25. "There can be little doubt that the judgments of the European Court of Justice establishing Member State liability for breach of Community law are among the most important that the Court has ever delivered." Jack Beatson \& Takis Tridimas, Introduction, in New Directions in European Public Law 1, 4 (Jack Beatson \& Takis Tridimas eds., 1998). Francovich itself is re exively described as a "landmark" (e.g., Paul Spink, Contravening EC Law: The Liability of the Member State, 48 N. Ireland L.Q. 111 (1997)) or "watershed" decision (e.g., Malcolm Ross, Beyond Francovich, 56 Mod. L. Rev. 55, 55 (1993)) de ${ }^{a}$ ning a new era of judicial protection. To avoid implying that the principle was novel, though, it is often remarked in the same breath that it has been presaged since the dawn of the Community. See infra note 150

26. See, e.g., de Búrca, supra note 21, at 234 ("[The Court] should seek a way of addressing the complex concerns which underpin the subsidiarity principle when it chooses a particular policy direction in interpreting an open-ended Treaty provision."). Professor Bermann also suggests that the Court should apply a subsidiarity analysis to its interpretation of Treaty provisions concerning, for example, free movement, largely "because it is a good way for the Court to demonstrate its own belief that subsidiarity matters." Bermann, supra note 2, at 401 .

27. See Waelbroeck, supra note 12, at 468 ("[T] he key idea behind the wide powers given 
This Article calls for the Court of Justice to apply subsidiarity to its own doctrine, using Francovich as an exemplar for what may be a considerably broader undertaking. ${ }^{29}$ As explored below, judicial subsidiarity-that is, the Court's evaluation pursuant to Article 5 of the need for and scope of Community law-is not only indicated, but required, by the EC Treaty. It does not necessarily follow, however, that state liability is contrary to the Treaty. Focusing on perhaps the most original and revolutionary aspect of the Francovich jurisprudence ${ }^{30}$ - state liability for failure properly to implement directives ${ }^{31}$-I argue that judicial subsidiarity undermines the Court's dominant justi ${ }^{\mathrm{a}}$ cation for state liability, the vindication of Community-law rights. But I proceed to demonstrate that an institutional theory of subsidiarity, informed by the interests of states in

to the national judges," in particular by Francovich, "is not any sort of 'subsidiarity' principle... but the reinforcement of the Community legal system by involving national judges in the decision-making process, increasing their powers, and ensuring greater ef ${ }^{a} c i e n c y$, if necessary, by a certain degree of harmonization of their powers."); cf. C.N. Kakouris, Do Member States Possess Judicial Procedural “Autonomy”? , 34 Common Mkt. L. Rev. 1389 (1997) (arguing that recent judicial developments con ${ }^{\mathrm{a}} \mathrm{rm}$ that there never has been any principle of judicial procedural autonomy, but that national procedures are instead essentially interstitial in nature).

28. See Harlow, supra note 21, at 224 (treating Member States as Community agents to be disciplined by state liability is "unhelpful," "insulting," and "sits uncomfortably with the Maastricht subsidiarity principle and ands no counterpart in the jurisprudence of federal courts"); Angela Ward, Effective Sanctions in EC Law: A Moving Boundary in the Division of Competence, 1 Eur. L.J. 205, 205-06 (1995) (noting, in contrast to mounting emphasis on pushing lawmaking authority to Member States, the "anomalous development ... in this climate of delegation with the somewhat wavering and confused attempts by the Court of Justice to elevate the rules on remedies for breach of Community law to the level of Community judicial regulation"). Of course, many would argue that Francovich is sustainable tecause it is compelled by the Treaty. See, e.g., Alan Dashwood, The Human Rights Opinion of the ECJ and Its Constitutional Implications 23 (Cambridge Centre for European Legal Studies, Occasional Paper No. 1, 1996) (suggesting that Francovich is consistent with judicial restraint and the spirit of the Maastricht Treaty).

29. This Article applies judicial subsidiarity to just one doctrine - namely, state liability for the non-implementation of directives-but much of the analysis suggests that it is both incumbent upon the Court, and appropriate, to apply judicial subsidiarity more broadly, particularly within the law of remedies. As the discussion in Part II indicates, however, judicial subsidiarity may be inappropriate in other contexts, such as where the Treaty may fairly be said to dictate the outcome. Accordingly, this analysis should be extended with caution.

30. Francovich is thought to have been instrumental in inaugurating a "third generation" of Community law focusing on secondary law rather than Treaty obligations. See Deirdre Curtin \& Kamiel Mortelmans, Application and Enforcement of Community Law by Member States: Actors in Search of a Third Generation Script, in Institutional Dynamics of European Integration: Essays in Honour of Henry G. Schermers, supra note 12, at 433.

31. Community non-compliance can be described in a dizzying variety of ways. See, e.g., Curtin \& Mortelmans, supra note 30, at 427-29; Francis Snyder, The Effectiveness of European Community Law: Institutions, Processes, Tools and Techniques, 56 Mod. L. Rev. 19, 24-27 (1993). As employed here, non-implementation refers to a Member State's failure to "transpose" a directive properly into national law, whether that consists of failing to do so on time, doing it incorrectly, or failing to do it at all. Much of the analysis, however, will also bear on cases in which a Member State has implemented the directive, but fails to enforce it. 
a federal system, redeems the Francovich holding by placing it on a new and sturdier foundation. ${ }^{32}$

Part I begins by describing the core principles governing the relation between Community and Member State law. It then discusses how Community law regarding national and Community law remedies evolved from a focus on maintaining supremacy and avoiding self-dealing toward a preoccupation with vindicating individual rights. This complex background is indispensable to understanding the context in which Francovich emerged, and shows how Community law both anticipated and betrayed subsidiarity even before the Maastrich Treaty embraced it.

Because there is at present no theory or practice of judicial subsidiarity, the principal task is to develop one. Part II describes the legal basis, feasibility, and scope of judicial subsidiarity and explores how this principle relates to the issue of Community remedies. I argue that the Court of Justice is obliged to heed judicial subsidiarity, together with its kindred principle of proportionality, in formulating remedial rules for Community law. Though this approach will prove challenging, it offers concrete advantages over the Court's present approach, which provides an incoherent basis for determining when it is necessary or appropriate to displace mtional law.

Finally, Part III examines how Francovich fares. The prevailing rationale for state liability emphasizes the importance of affording judicial protection to aggrieved individuals, but this justi ${ }^{\mathrm{a}}$ cation is neither compatible with subsidiarity nor consistent with existing doctrine. I then rehabilitate state liability by explaining how it solves collective action problems pertaining to the formulation and enforcement of Community legislation. Put simply, Member States, which are the indispensable players in the Community political process, have strong incentives to renege on their legislative agreements by failing to implement Community directives. Knowing this, they may be tempted to surrender authority to Community institutions and to enact legislation that reduces the prospect of cheating by decreasing discretion. State liability offers a decentralized enforcement mechanism that may, if properly developed, balance compliance and discretion in ways that will promote the Community's distinctive brand of federalism.

32. As will become clear, this Article connes itself to assessing whether Member State liability is consistent with subsidiarity, and does not examine in detail the analytically prior question of whether the judgment has an adequate legal foundation. As explained below, however, it is necessary to determine whether the Court's rule is compelled-in the strongest sense - by the Treaty, since in that case the question of subsidiarity would be moot. 


\section{THE DEVELOPING LAW OF COMMUNITY REMEDIES}

\section{A. The Core of Community Law}

Though the EC Treaty de ${ }^{a}$ es easy characterization, ${ }^{33}$ the legal order of the European Community is suffused with the tensions characteristic of a federal system. The Treaty deanes the respective powers of the Community institutions and Member States, but fails to place much in the way of formal limits on Community power. ${ }^{34}$ Instead, both extraordinary ${ }^{35}$ and ordinary $^{36}$ processes of legal

33. In the archetypal experience of federalism, the Treaty of Rome began as a conventional international treaty but evolved into something more of a constitution. See Case 26/62, Algemene Transport-en Expedetie Onderneming van Gend en Loos NV v. Nederlands Administratie der Belastingen, 1963 E.C.R. 1, 12, [1963] 2 C.M.L.R. 105, 129 (1963) [hereinafter Van Gend en Loos] (describing Community as a "new order of international law"); see also Case 294/83, Parti Ecologiste "Les Verts" v. European Parliament, 1986 E.C.R. 1339, 1339, [1987] 2 C.M.L.R. 343, 343 (1986) (characterizing the Treaty as a "basic constitutional charter"); Opinion 1/91 (Re. The Draft Treaty on a European Economic Area), 1991 E.C.R. I-6079, I[ 21, [1992] 1 C.M.L.R. 245, I[21 (1991) ("[T] form of an international agreement, nonetheless constitutes the constitutional charter of a Community based on the rule of law."); George Bermann et al., Cases and Materials on European Community Law 30 (1993) (inquiring whether "it would be fair to conclude that the EEC Treaty takes the form of an international agreement, enjoys the status of a constit ut tion and performs the function of legislation").

34. See John Temple Lang, European Community Constitutional Law: The Division of Powers Between the Community and Member States, 39 N. Ireland L.Q. 209, (concluding that there are no clear legal limits on Community authority); Lenaerts, Constitutionalism, supra note 1, at 220; Theodor Schilling, A New Dimension of Subsidiarity: Subsidiarity as a Rule and a Principle, 14 Y.B. Eur. L. 203, 234 (1994) (same); J.H.H. Weiler \& Nicolas J.S. Lockhart, Taking Rights Seriously: The European Court of Justice and its Fundamental Rights Jurisprudence - Part I 32 Common Mkt. L. Rev. 51, 64 (1995) (same); cf. Alan Dashwood, The Limits of European Community Powers, 21 Eur. L. Rev. 113 (1996). An important loophole is Article 308, which enables Community action on a more expansive basis, at least when no more speciac basis for legislation may be found. See EC Treaty art. 308 (ex art. 235). Whatever the nominal limits imposed by the Treaty, it seems clear that as a practical matter the Community's swathe is considerably wider. See Stephen Weatherill, Law and Integration in the European Union 38 (1995).

35. The Treaty remained amenable to signia ${ }^{\mathrm{a}}$ cant change, in part through Intergovernmental Conferences (IGCs). See George A. Bermann, The European Intergovernmental Conference: An American Perspective, 25 Syracuse J. Int'l L. \& Com. 61 (1998). In being revised, the Treaty is often custom-tailored to accommodate strongly held national positions. See, e.g., Curtin \& Mortelmans, supra note 30, at 454 n.156 (citing examples from Maastricht Treaty); Sally Langrish, The Treaty of Amsterdam: Selected Highlights, 23 Eur. L. Rev. 3, 5-7 (1998) (citing examples from Amsterdam Treaty).

36. Legislation requires the approval of the Council of Ministers, which is composed of one ministerial-level representative from each Member State authorized to commit the government of that Member State. See EC Treaty art. 203 (ex art. 146). The Treaty's requirement of unanimous agreement by the Council in the most important areas of Community authority, together with a tradition of permitting a "political" veto by a single Member State, gave each Member State an extraordinary amount of control over Community action. See Bermann, supra note 2 , at $353 \& \mathrm{nn} .83-85$. This control was diminished by provisions in the Maastricht Treaty permitting qualiaed-majority decisions in a number of areas, and by the erosion of the traditional political veto. See Bermann, supra note 33, at 54-55. The Single European Act also enhanced the relative authority of the European Parliament by permitting it (through the "co-operation procedure") to reject a common position adopted by a qualiaed majority of the Council, in which case the Council can adopt the original proposal only by unanimity. See 
change, as well as the execution and judicial enforcement of Community law, ${ }^{37}$ depend on Member States and their institutions, thereby placing a political constraint on Community institutions' ambitions. The Treaty's mechanisms for legislating are particularly distinctive.

Member States are heavily involved in promulgating both regulations and directives, but their role in implementation varies. For regulations, Member States must create an environment in which the legislation can operate, ${ }^{38}$ but need take no formal action, and are ordinarily prohibited from doing so. ${ }^{39}$ In contrast, the entire premise of the directive is to vest Member States with discretion. ${ }^{40}$ Directives provide a legislative template, then require that Member States bring Community law into being within their borders by adopting speci ${ }^{\mathrm{a}} \mathrm{c}$ implementing legislation-or by amending existing legislation in order to accommodate changes wrought by the directivewithin a speci ${ }^{\mathrm{a}} \mathrm{c}$ period of time. ${ }^{41}$ According to Article 249 (ex art. 189) of the EC Treaty, directives are "binding, as to the result to be achieved, upon each Member State to which it is addressed, but shall leave to the national authorities the choice of form and methods." ${ }^{2}$ However, this latitude as to choices and methods is not sac-

EC Treaty art. 252 (ex art. 189c); see also Weatherill, supra note 34, at 73. The Maastricht Treaty further added the "co-decision" procedure, in which Parliament has the right to exercise what might be considered a legislative veto. See EC Treaty art. 251 (ex art. 189b). The Amsterdam Treaty has substantially expanded the application of this procedure, thereby increasing - if not achieving - the rationalization of Community legislative procedures. See Lenaerts, Federalism: Essential Concepts in Evolution, supra note 1, at 760-65.

37. See Koen Lenaerts, Some Reflections on the Separation of Powers in the European Community, 28 Common Mkt. L. Rev. 11, 14-15 (1991).

38. See Curtin \& Mortelmans, supra note 30 , at 429 .

39. See EC Treaty art. 249 (ex art. 189) (providing that a regulation "shall have general application," and "shall be binding in its entirety and directly applicable in all Member States"). Indeed, Member States are foreclosed from adopting measures to implement regulations unless required to do so by the regulation in question or necessitated by some aspect of their national legal systems. See Mark Brealey \& Mark Hoskins, Remedies in E.C. Law 6 (1994) (citing cases); Hartley, supra note 6, at 216 (citing tachograph regulation); Mark Hoskins, Tilting the Balance: Supremacy and National Procedural Rules, 21 Eur. L. Rev. 365, 368-69, nn.27-28 (1996) (citing cases).

40. See, e.g., Stephen Weatherill, Beyond Preemption? Shared Competence and Constitutional Change in the European Community, in Legal Issues of the Maastricht Treaty 21 (David O'Keefe \& Patrick Twomey eds., 1994) ("The very nature of Directives as such is to yield a certain differentiated integration, through their (not always timeous) transposition into national law in accordance with national techniques ... ..). See Hartley, supra note 6, at 215-16; Nicholas Green, Directives, Equity and the Protection of Individual Rights, 9 Eur. L. Rev. 295, 300-02 (1984); and Hoskins, supra note 39, at 368-69, for skeptical assessments of whether this distinguishes regulations and directives in practice.

41. Member States are sometimes able to rely on existing legislation so long as that legislation guarantees the full application of the directive. See, e.g., Case 29/84, Commission v. Germany, 1985 E.C.R. I-1661, II 23, [1986] 3 C.M.L.R. 579 (1985).

42. EC Treaty art. 249 (ex art. 189). As the language of article 249 indicates, directives need not be addressed to all Member States-arguably another means of enhancing their discretion). See Paul Craig, Directives: Direct Effect, Indirect Effect and the Construction of 
rosanct, ${ }^{43}$ and may be constrained by Treaty provision ${ }^{44}$ or simply by the prescriptiveness of the directives themselves. ${ }^{45}$

Both regulations and directives are reinforced by principles designed to establish a common Community legal system. Supremacy, the most basic and pervasive principle of Community law's primacy, is conspicuously absent from the Treaty, but was nevertheless discovered by the Court of Justice. ${ }^{46}$ Accordingly, all binding instruments of Community law (including, but not limited to, the Treaty, regulations, and directives ${ }^{47}$ ) prevail over national laws of any type, including national constitutions, ${ }^{48}$ and must be respected by all Member State instit utions. ${ }^{49}$

National Legislation, 22 Eur. L. Rev. 519, 521 (1997).

43. A few commentators take the position that Article 249 limits the Community's ability to use the directive to detail an exhaustive set of rules with no leeway or accommodation of varying national preferences or practices. See Secha Prechal, Directives in European Co mmunity Law: A Study of Directives and Their Enforcement in National Courts 17 \& nn.1923 (1995).

44. See, e.g., Case 48/75, In re Royer, 1976 E.C.R. 497, 517-19, [1976] 2 C.M.L.R. 619, 652-54 (1976).

45. As employed here, a directive's prescriptiveness does not necessarily connote regulatory stringency, but instead refers to the degree to which the directive constrains a Member State's regulatory exibility in meeting a particular Community objective. Given the common Community objective of harmonization, however, even directives representing the lowest common denominator may constrain the ability of Member States to set more demanding standards. See Jonathan Golub, State Power and Institutional In uence in European Integration: Lessons from the Packaging Waste Directive, 34 J. Comm. Mkt. Stud. 313, 328-30 (1996) (describing example of Packaging Waste Directive). Directives may also deliberately accentuate Member State prerogatives. See Weatherill, supra note 34, at 20 (discussing safeguard clauses in directives permitting Member State derogations). Pre-Maastricht deliberations considered seriously whether the directive should be abolished and replaced by a more general instrument, "the law," which could afford Member States an entirely variable discretion in implementation. See European Commission Proposal on Democratic Legitimacy: Hierarchy of Norms, Executive Powers, Legislative Procedure (Co-Decision), art. 189 (Draft Text), reprinted in The Treaty of Maastricht 230 (Richard Corbett ed., 1993); see also Treaty on European Union, Decl. 16 on the Hierarchy of Community Acts, Feb. 7, 1992, 1992 O.J. (C 224) 1, [1992] 1 C.M.L.R. 719, 785 (1992), incorporated in EC Treaty [hereinafter TEU, or Maastricht Treaty] (postponing reconsideration of directive until 1996 Intergovernmental Conference (IGC)); Prechal, supra note 43, at 2-3.

46. See Mancini, supra note 4, at 599 (describing Community law supremacy as "a product of judicial creativeness"). For general discussions of the principle's development, see Clive Lewis, Remedies and the Enforcement of Community Law 39-42 (1996); Eric Stein, Lawyers, Judges, and the Making of a Transnational Constitution, 75 Am. J. Int'l L. 1, 10-16 (1981).

47. See Case 6/64, Costa v. ENEL, 1964 E.C.R. 585, 594, [1964] C.M.L.R. 425 (1964). As Costa indicated, the idea that supremacy extends to Community legislation, not just to Treaty provisions, is implicit in the direct applicability of regulations. Of course, the Treaty prevails over any other inconsistent Community law, and the Court of Justice is empowered to review and anally determine the existence of any such inconsistencies. See EC Treaty arts. 220 (ex art. 164), 230-33 (ex arts. 173-76).

48. See Case 11/70, Internationale Handelgesellschaft mbH v. Einfuhr-und Vorratsstelle für Getreide und Futtermittel, 1970 E.C.R. 1125, II 3, [1972] C.M.L.R. 255, II 3 (1972); see also Prechal, supra note 43, at 121-22.

49. See generally John Temple Lang, The Duties of National Authorities Under Community Constitutional Law, 23 Eur. L. Rev. 109 (1998). 
Two other principles, direct applicability and direct effect, are akin to supremacy but a bit more unusual. Direct applicability derives from Article 249's proviso that regulations are to be "directly applicable in all Member States." 50 Direct applicability distinguishes between regulations, which are by de ${ }^{a}$ nition directly applicable, and directives, which require Member States to enact implementing legislation. Direct effect, like supremacy, is absent from the Treaty, which has no doubt contributed to the confusion about its basic nature. ${ }^{51}$ Nevertheless, it is one of the foundations of Community law. ${ }^{52}$ The direct effect principle generally provides that Community law norms that are clear, precise, and unconditionalsuch that further action is required by neither Community nor mtional authorities - may be enforced by private parties before rational institutions..$^{53}$

The relationship between direct effect, which ensures the supremacy of Community law for all Member States, and directives, which are intended to preserve Member State authority, has proved problematic. Directives would seem unlikely candidates for direct effect, since they by de ${ }^{a}$ nition require further action by national institutions. ${ }^{54}$ But the need for direct effect was still readily apparent,

50. EC Treaty art. 249 (ex art. 189).

51. See Hartley, supra note 6, at 206-07 (considering whether direct effect and direct applicability are the same, and concluding that it makes little difference); see also John Tillotson, European Community Law: Text, Cases and Materials 170 (1993) (attributing confusion in part to the Court of Justice, which has "used [the terms] interchangably in the sense of the creation of Community rights for individuals"); Peter Oliver, Interim Measures: Some Recent Developments, 29 Common Mkt. L. Rev. 7, 12 n.16 (1992) (disavowing distinction between direct applicability and direct effect); J.A. Winter, Direct Applicability and Direct Effect, Two Distinct and Different Concepts in Community Law, 9 Common Mkt. L. Rev. 425 (1972) (anticipating this confusion).

52. See, e.g., Hartley, supra note 6, at 215 ("The granting of direct effect to directives has probably done more than any other initiative by the European Court to enhance the effectiveness of Community law"); Ann-Marie Burley \& Walter Mattli, Europe Before the Court: A Political Theory of Legal Integration, 47 Int'l Org. 41, 45-46, 60 (1993) (Van Gend en Loos "announced a new world"); Weatherill, supra note 40, at 97 ("Were direct effect not to form part of the constitutional pattern of the EC legal order, the dynamic development and pract $\mathrm{i}$ cal signiacance of EC law would be immeasurably reduced .... Direct effect, unmentioned in the Treaty, is of far wider signia cance than direct applicability.").

53. See Van Gend en Loos, 1963 E.C.R. at 13, 12 (holding that Article 25 (ex art. 12) of the Treaty imposed a "clear and unconditional" prohibition against increasing customs duties on imports from other Member States). Van Gend en Loos described the Community as a "new legal order" that did not "merely create[ ] mutual obligations between the Contracting States," but also imposed duties and obligations on individuals. That reasoning is generally regarded as rejecting a "dualist" view of the Community, according to which claims might be brought only at an international level by the sovereign states (or, presumably, the Commission), in favor of a "monist" view permitting an integrated view of Community law and mtional law. See Tillotson, supra note 51, at 167; cf. Henry G. Schermers \& Denis Waelbroeck, Judicial Protection in the European Communities $\S \S 201-38$ (5th ed. 1992) (discussing monism and dualism in European Communities and Member States).

54. See Prechal, supra note 43, at 246-47 (summarizing the debate anticipating the question of whether directives might ever be considered directly effective). 
since without it Member States could protably ignore the deadlines for implementing directives. Eventually, the Court tentatively indicated that directives might also be imbued with direct effect, ${ }^{55}$ based on the rationale that Member States were estopped from asserting a defense of non-implementation by their wrongdoing. ${ }^{56}$ Consistent with that rationale, directives may have "vertical" direct effect in favor of private parties against Member States as of the deadline for implementation, ${ }^{57}$ but they lack the "horizontal" direct effect necessary to enable suit against other parties. ${ }^{58}$ The Court partly redressed this limit by developing a doctrine of uniform interpretation (interprétation conforme), described as "indirect effect" in English-language commentary. By requiring national courts to interpret national law in light of Community law, indirect effect enabled horizontal relief against private parties that might otherwise

55. See Case 41/74, Van Duyn v. Home Oface, 1974 E.C.R. 1337, q 12, [1975] 1 C.M.L.R. 1, If 12 (1974). Even in Van Duyn the Court equivocated, stating merely that "[i]t would be incompatible with the binding effect attributed to a directive ... to exclude, in principle, the possibility that the obligation which it imposes may be invoked by those concerned." Id. Apparently convinced of the Court's technique, Judge Pescatore contended even in 1983 that "[i]n spite of what has been written by several commentators, the Court has never said that directives have 'direct effect' and it has never tried to blurr [sic] the difference which is made by Article [249] between regulations on the one hand, or directives and decisions on the other hand." Pierre Pescatore, The Doctrine of "Direct Effect": An Infant Disease of Community Law, 8 Eur. L. Rev. 155, 167 (1983).

56. Sometimes described as the principle nemo auditur proprium turpitudinem allegans. See Case 8/81, Becker v. Finanzamt Münster-Innenstadt, 1982 E.C.R. 53, ITI 24-25, [1982] 1 C.M.L.R. 499, III 24-25 (1982) ("[A] Member State which has not adopted the implementing measures required by the directive within the prescribed period may not plead, as against individuals, its own failure to perform the obligations which the directive entails."); see also Case 148/78, Pubblico Ministero v. Ratti, 1979 E.C.R. 1629, I[22, [1980] 1 C.M.L.R. 96, II 22 (1979). For extra-judicial endorsements of the estoppel theory, see Mancini, supra note 4, at 602; Lenaerts, Constitutionalism, supra note 1, at 213. In an effort to dissolve the embarrassing contrast with regulations, the Court seemed to suggest that the estoppel theorywhile most clearly pertaining to directives - was a universal explanation of direct effect. See Case 148/78, Ratti, 1979 E.C.R. at III 19-21; Becker, 1982 E.C.R. at IIII 22-25; cf. Hartley, supra note 6, at 206-07 (discussing the dilemma for direct effect posed by Article 249). The reasoning was not in fact entirely alien to Treaty provisions and regulations; it might be argued that any government diminishing the force of that law through national substantive or procedural impediments ought at least be denied the ability to rely upon them itself.

The estoppel theory has nonetheless proven controversial, see Prechal, supra note 43, at 249-60, but the direct effect principle is by now so well-established that its precise grounding may be irrelevant. See, e.g., Opinion of Advocate General Tesauro, Case C-213/89, The Queen v. Secretary of State for Transport ex parte Factortame Ltd., 1990 E.C.R. I-2433, 2454, [1990] 3 C.M.L.R. 573, 584-85 (1990) [hereinafter Factortame].

57. See Case 148/78, Ratti, 1979 E.C.R. 1629, IIII 18-24; see also Case 8/81, Becker v. Finanzamt Münster-Innenstadt, 1982 E.C.R. 53, IIII 23-25, [1982] 1 C.M.L.R. 499, IIII $23-25$ (1982).

58. See Case C-91/92, Faccini Dori v. Recreb Srl, 1994 E.C.R. I-3325, [1995] 1 C.M.L.R. 665 (1994) (reaf ${ }^{\mathrm{a}} \mathrm{rming}$ rule against horizontal direct effect of directives); cf. Prechal, supra note 43, at 295-305 (noting importance of lack of horizontal direct effect, and reviewing academic debate). 
be put out of reach by the Member State's failure to implement a particular directive. ${ }^{59}$

The impact of direct effect on Member State authority and Community federalism is also complex. Obviously, it took back an autonomy that directives seemed to confer. ${ }^{60}$ While directives nominally confer bounded discretion to Member States, and depend on their agency, direct effect meant that, in some cases and for certain purposes, Member State action was irrelevant. ${ }^{61}$ Directives, in short, became more and more like regulations. ${ }^{62}$ Equally important, direct effect enabled supremacy by increasing the opportunity for individuals to challenge Member State actions on the basis of Community law. ${ }^{63}$

At the same time, direct effect was also consistent in important ways with a decentralized Community. Because it charged private parties and national courts with the enforcement of Community law, it afforded a decentralized alternative to relying on federal enforcement by the Commission. ${ }^{64}$ Moreover, while direct effect provided a Community law platform for remedies, it did not dictate the kind of remedies conferred; by de ${ }^{a}$ nition, no further legislation was necessary to give rise to the right in question, but more might be required to articulate the right's effects. ${ }^{65}$ Direct effect may thus be

59. See generally Gráinne de Búrca, Giving Effect to European Community Directives, 55 Mod. L. Rev. 215 (1992); Craig, supra note 42, at 524-38; Christopher Docksey \& Barry Fitzpatrick, The Duty of National Courts to Interpret Provisions of National Law in Accordance with Community Law, 20 Indus. L.J. 113 (1991).

60. See Damien Chalmers, Judicial Preferences and the Community Legal Order, 60 Modern L. Rev. 164, 183 (1998).

61. Direct effect did not, however, relieve a Member State from implementing the directive. See Prechal, supra note 43, at 27.

62. See Francis Jacobs \& Kenneth Karst, The "Federal" Legal Order: The U.S.A. and Europe Compared - A Juridical Perspective, in 1 Integration Through Law: Methods, Tools and Institutions-A Political, Legal and Economic Overview 169, 235 (Mauro Cappelletti et al. eds., 1986) ('In . . . giving 'direct effect' to certain provisions of directives, the Court has approximated them to regulations or to federal legislation."); see also Hartley, supra note 6 , at 215-16 (concluding that direct effect meant that "the distinction between regulations and directives was blurred and the structure of the Treaty deformed"). The Court took little pains to maintain the distinction. Its subsequent decision in Emmott v. Minister for Social Welfare, 1991 E.C.R. I-4269-since limited-took account of the "particular nature of directives" only to hold that it had the effect of decreasing the procedural autonomy accorded Member States, at least so as to suspend the operation of time-limits during (both lawful and unlawful) periods of transposition. See Hoskins, Tilting the Balance, supra note 39, at 368-69; see also infra note 91 (discussing Emmott).

63. See Mancini, supra note 4, at 600-01; see also Burley \& Mattli, supra note 52, at 66 (describing differing means for resolving federal and state interests in a federal system).

64. See EC Treaty art. 226 (ex art. 169); see also infra text accompanying notes 494-512 (describing Commission authority).

65. See generally Schermers \& Waelbroeck, supra note 53, at 138-39. These distinctions are sometimes obscured-for example, direct effect is sometimes said to involve the creation of individual rights. See, e.g., Case 265/78, Ferwerda v. Produktschap voor Vee en Vlees, 1980 E.C.R. 617, II 10, [1980] 3 C.M.L.R. 737, II 10 (1980) (discussing the obligation of national courts "to protect the rights which the subject obtains through the direct effect of 
regarded as a jurisdictional, or perhaps remedial, principle of the most basic kind: if Community law in fact confers rights upon individuals, it also confers mandatory jurisdiction upon Member States' national legal systems-principally courts - to protect those rights. ${ }^{66}$ Direct effect, viewed in this way, means merely that Community law must have some practical or operative effect-no more, in Judge Pescatore's opinion, than we would expect of any law. ${ }^{67}$ Indirect effect, too, ultimately came to observe the limits of national law. ${ }^{68}$ For a fuller conception of Community remedies, the Court had to look elsewhere.

\section{B. The Development of Community Law Remedies}

The somewhat tortured relationship between Community and ational law largely results from the fact that Community law relies on Member State courts. Non-compliance by sovereigns is a problem common to all legal systems, perhaps especially to federal systems. In the Community, however, the objects of enforcement efforts are also its principal instruments. In the absence of lower Community courts, national courts are required to enforce what amounts to foreign law, and do so against national institutions that may have a vested interest in resisting application-as well as means of retaliation. ${ }^{69}$ As a result, Community law may be insuf ${ }^{a}$ ciently enforced, or perhaps vary overmuch, among Member States. ${ }^{70}$

Community law"); van Gend en Loos, 1963 E.C.R. at 13, [1963] C.M.L.R. at 130; Opinion of Advocate General Warner, Case 33/76, Rewe-Zentral-ananz, 1976 E.C.R. at 2002, [1977] 1 C.M.L.R. at 546; Tillotson, supra note 51, at 170. But it is clear from the direct effects jurisprudence that rights are instead the precondition for direct effect. See Lenaerts, Constitutionalism, supra note 1, at 212 (Direct effect means that "the rule itself states rights and duties which can be enforced by national courts."). The distinction between direct effect and remedies, or even between rights and remedies, is not wholly satisfactory, save for the fact that national legal orders are interposed. See Chalmers, supra note 60, at 186-89; Douglas Laycock, Modern American Remedies: Cases and Materials 1 (2d ed. 1994) ("A remedy is anything a court can do for a litigant who has been wronged or is about to be wronged ... it is the means by which substantive rights are given effect.").

66. See, e.g., Prechal, supra note 43, at 276 ("Direct effect is the obligation of a court or another authority to apply the relevant provision of Community law, either as a norm which governs the case or as a standard for legal review."). Prechal describes direct effect as a procedural question, distinct from the substantive inquiry into whether Community law confers rights, but does not mean to exclude its characterization as remedial. See id. at 124-29.

67. See Pescatore, supra note 55, at 155-56, 177; accord Opinion of Advocate General van Gerven, Case C-128/92, H. J. Banks \& Co. v. British Coal Corp., 1994 E.C.R. I-1209, I1237, [1994] C.M.L.R. 30 (1994); Derrick Wyatt, The Direct Effect of Community Social Law - Not Forgetting Directives, 8 Eur. L. Rev. 241, 241 (1983).

68. As von Colson cautioned, a court is obliged to interpret national legislation only "in so far as it is given discretion to do so under national law." Case 14/83, von Colson \& Kamann v. Land Nordrhein-Westfalen, 1984 E.C.R. 1891, I 28, [1986] 2 C.M.L.R. 430, I28 (1986); see also Case C-106/89, Marleasing SA v. La Comercial Internacional de Alimentacíon SA, 1990 E.C.R. 4135, Iा 8, [1992] 1 C.M.L.R. 305, II 8 (1992).

69. The Court of First Instance, which was established in 1989, has jurisdiction over a variety of matters, but—signiacantly for instant purposes — has no jurisdiction over any actions 
This fundamental problem in ${ }^{\circ}$ uenced the Court's development of a Community law of remedies, which is conventionally understood to have evolved through three generations. The ${ }^{a}$ rst generation developed the basic relationship between Community and national law already described. The second generation saw the Court accommodate the expansion of Community law into new substantive areas by deferring to national remedies for its breach, but as a consequence it suffered ineffectiveness and variation in Community

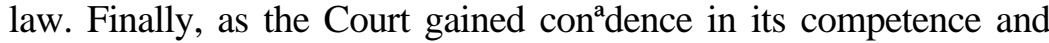
political standing, it began to supplement direct effect and national procedures by more aggressively cultivating Community law remedies to vindicate individual rights. Francovich is plainly regarded as the capstone of this third generation. ${ }^{71}$

This account is in the teleological tradition of the Court and mainstream European scholarship, and is vital to understanding both Francovich and its critical reception. ${ }^{72}$ But the image of a long march toward the effective judicial protection of individual rights misses an important early counter-theme: the Court's perception that it should only dictate remedies where necessary to sustain the supremacy of Community law or to address the prospect for Member State self-dealing. These themes, though vital to reconciling the Court's doctrine with the principle of subsidiarity, became obscured by the Court's increasing focus on the importance of vindicating individual rights.

brought by or against a Member State. See Hartley, supra note 6, at 63 .

70. This is the central concern of much of the Court's case law, and much of the academic literature on EC law. For just one overview, see Bert Swart, From Rome to Maastricht and Beyond: The Problem of Enforcing Community Law, in Enforcing European Community Rules: Criminal Proceedings, Administrative Procedures and Harmonization ch. 1 (Christopher Harding \& Bert Swart eds., 1996).

71. See Curtin \& Mortelmans, supra note 30, at 432-35; see also David O'Keefe, Third Generation Remedies and Sex Equality Law, in Sex Equality Law in the European Union ch. 10 (Tamara Hervey, ed. 1996); Bruce Carolan, Winning Isn't Everything: National Judicial Protection of Rights under European Community Law, 5 Tulsa J. Comp. \& Int'l L. 89 (1997); David O'Keefe, Judicial Protection of the Individuals by the European Court of Justice, 19 Fordham Int'l L.J. 901 (1996); Lambros Papadias, Interim Protection Under Community Law Before the National Courts: The Right to a Judge with Jurisdiction to Grant Interim Relief, 1994 Legal Issues Eur. Integration 153, 173-74, 176-77 (describing interim relief as part of a "second era" of relationship between national and Community law).

72. See, e.g., Joxerramon Bengoetxea, The Legal Reasoning of the Court of Justice: Towards a European Jurisprudence 250, 251-53, 255-56 (1993) (describing Court's "teleological" method of interpretation); L. Neville Brown \& Tom Kennedy, The Court of Justice of the European Communities 316-21 (4th ed. 1994) (same); Hartley, supra note 6, at 85-90 (describing substantial and express tendency on part of Court of Justice to decide matters based on policy objectives, even notwithstanding Treaty language); Carlos Ball, The Making of a Transnational Capitalist Society: The Court of Justice, Social Policy, and Individual Rights Under the European Community's Legal Order, 37 Harv. Int'1 L.J. 307, 337-45 (1996); Nial Fennelly, Legal Interpretation at the Court of Justice, 20 Fordham Int'l L.J. 656 (1997). 


\section{The Traditional Approach to Remedies}

As previously noted, the Court of Justice originally considered the doctrine of direct effect to be entirely consistent with vesting remedial discretion in Member States. As the Court spelled out in

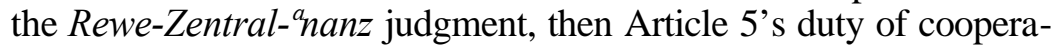
tion meant that:

[T] he national courts are entrusted with ensuring the legal protection conferred on individuals by the direct effect of the provisions of Community law ... . it is for the national legal order of each Member State to designate the competent courts and to lay down the procedural rules for proceedings designed to ensure the protection of the rights which individuals acquire through the direct effect of Community law. ${ }^{73}$

Persistent and signi $i^{\mathrm{a}}$ cant differences would trigger the Court's supervisory function. ${ }^{74}$ But the Court perceived that it was not competent "to issue general rules of substance and procedur[e]," 75 a conclusion that was certainly over-determined. National rules aready existed, were familiar to national courts, permitted consistent treatment of Community and national law claims within each Member State, and were certainly more palatable to Member States as a political matter. ${ }^{76}$ The alternative, which involved identifying and assessing national differences, then choosing the proper remedies from among the many possibilities offered, must have seemed like a staggering enterprise, as would the continuing burden of ferreting out and evaluating meaningful deviations. ${ }^{77}$ In any event, the

73. Case 33/76, Rewe-Zentral-" nanz, 1976 E.C.R. at II 5, [1977] 1 C.M.L.R. at II 5. (The Court's decision in Case 45/76, Comet v. Produktschap voor Siergewassen, 1976 E.C.R. 2043, If 12, [1977] 1 C.M.L.R. 533 (1976), is entirely identical in all relevant respect s.) See also Opinion of Advocate General Warner, Case 33/76, Rewe-Zentral-ananz, 1976 E.C.R. 1989, [1977] 1 C.M.L.R. 533, 546-47 (citing cases); Case 50/76, Amsterdam Bulb v. Produktschap voor Siergewassen, 1977 E.C.R. 137, II 33, [1977] 2 C.M.L.R. 218 (1977) [hereinafter Amsterdam Bulb ] ("[I]n the absence of any provision in the Community rules providing for speciac sanctions to be imposed on individuals for a failure to observe those rules, the member-States are competent to adopt such sanctions as appear to them to be appropriate.").

74. See EC Treaty art. 200 (ex art. 164) ("The Court of Justice shall ensure that in the interpretation and application of this Treaty the law is observed."); see, e.g., Case 130/79, Express Dairy Foods v. Intervention Board for Agricultural Produce, 1980 E.C.R. 1887, II 12, [1981] 1 C.M.L.R. 451 (1980).

75. Case 130/79, Express Dairy Foods, 1980 E.C.R. at II 12, [1981] 1 C.M.L.R. at II 12.

76. See Rachel Crawford Smith, Remedies for Breaches of EU Law in National Courts: Legal Variation and Selection, in The Evolution of EU Law (Paul Craig \& Gráinne de Búrca eds., 1999); April Philippa Tash, Note, Remedies for European Community Law Claims in Member State Courts: Toward a European Standard, 31 Colum. J. Transnat'l L. 377, 382 (1993); cf. Erie R.R. Co. v. Tompkins, 304 U.S. 64 (1938) (considering similar discrimination issue in holding that federal courts sitting in diversity cases must apply state substantive law).

77. Perhaps having this prospect in mind, Advocate General Warner remarked that in the absence of detailed Community legislation, "there is really no alternative to the application of 
Court cautioned that it was for the Community's political institutions to take steps to "eliminate the differences between the provisions laid down in such matters by law, regulatory and administrative action in member states," and even then only "if those differences are found to be such as to cause distortion or to affect the functioning of the common market."'78

But the Court repeatedly reiterated two minimum conditions for national law: nondiscrimination and effectiveness. ${ }^{79}$ Nondiscrimination meant that the national legal system could not impose conditions on the exercise of directly effective Community law that were less favorable than for comparable actions arising under domestic law. ${ }^{80}$ This established a remedial baseline for Community rights and avoided patent discrimination, while equally avoiding any politically charged appraisal of Member State motives. But the most signi ${ }^{\mathrm{a}}$ cant limits on remedies already applied to rights arising

the remedies and procedures prescribed by national law." Opinion of Advocate General Warner, Case 33/76, Rewe-Zentral-" nanz, 1976 E.C.R. at 2003, [1977] 1 C.M.L.R. at 547.

78. Case 33/76, Rewe-Zentral-ananz, 1976 E.C.R. 1989, [1977] 1 C.M.L.R. 533 (1976); see also Cases 205 to 215/82, Deutsche Milchkontor GmbH and Others v. Germany, 1983 E.C.R. 2633, II 24; Tash, supra note 76, at 383 \& n.26 (citing case law, and asserting that the Court "accompanied every ruling authorizing specia application of national rules" with a warning that future Community legislation was potentially preemptive). The other instit ut tions occasionally took up the challenge by specifying the remedies in the underlying legislation. See Chalmers, supra note 60, at $187 \mathrm{n} .29$ (citing examples).

79. See Enrique Alonso Garcia, Is Europe Ready for the Administrative Law Remedial Revolution?-Litigation Before National Courts of the EEC Member States and Interim Relief, 42 Admin. L. Rev. 181, 195-203 (1990) (considering right to bypass constitutional courts and principles of constitutional due process, as additional exceptions to general competence of Member States regarding remedies).

80. Also known as the principle of comparability. See Case 33/76, Rewe-Zentral-ananz 1976 E.C.R. at II 5, [1977] 1 C.M.L.R. at II 5; Case 265/78, Ferwerda v. Produktschap voor Vee en Vlees, 1980 E.C.R. 617, II 10, [1980] 3 C.M.L.R. 737 (1980). The Court summarized its approach in the Yugoslav Maize judgment:

... [W] [Wilst the choice of penalties remains within [Member States'] discretion, they must ensure in particular that infringements of Community law are penalized under conditions, both procedural and substantive, which are analogous to those applicable to infringements of national law of a similar nature and importance and which, in any event, make the penalty effective, proportionate and dissuasive.

Moreover, the national authorities must proceed, with respect to infringements of Community law with the same diligence as that which they bring to bear in implementing corresponding national law.

Case 68/88, Commission v. Greece (Yugoslav Maize), 1989 E.C.R. 2965, 2985, [1989] 1

C.M.L.R. 31 (1989)

How to determine which national law actions were comparable, and the importance of that determination, was unclear. See, e.g., Case 158/80, Rewe-Handelsgesellschaft Nord mbH v. Hauptzollamt Kiel, 1981 E.C.R. 1805, If 44, [1982] 1 C.M.L.R. 31 (1981) (“'T] he system of legal protection established by the Treaty, as set out in Article 177 in particular, implies that $i$ must be possible for every type of action provided for by national law to be available for the purpose of ensuring observance of Community provisions having direct effect, on the same conditions concerning the admissibility and procedure as would apply were it a question of ensuring observance of national law.") (emphasis added); $c f$. Opinion of Advocate General Jacobs, Case C-62/93, BP Supergas v. Greece, 1995 E.C.R. I-1883 (indicating that Member States should interpret nondiscrimination principle broadly). 
under national law, for example, those stemming from principles of sovereign or parliamentary immunity. ${ }^{81}$ Where Community law rights threatened their national interests, Member States could move to limit remedies so long as those limits applied irrespective of the source of law. ${ }^{82}$ As a consequence, the nondiscrimination principle had relatively little bite. ${ }^{83}$

The second limitation was the principle of effectiveness. As originally expressed, Member States were not permitted to make it "impossible in practice" to exercise rights conferred by Community law. ${ }^{84}$ Thus, for example, the Court held that claimants must be allowed more than nominal recovery, ${ }^{85}$ and national rules relating to

81. See, e.g., Case C-213/89, Factortame, 1990 E.C.R. 2433, [1990] 3 C.M.L.R. 375 (1990).

82. The laws would be impermissible, however, if they proved to render the exercise of Community rights "virtually impossible." See Case 199/82, Amminstrazione delle Finanze dello Stato v. San Giorgio, 1983 E.C.R. 3595, II 17, [1985] 2 C.M.L.R. 658, II 17 (1983).

83. But see Case 180/95, Draehmpaehl v. Urania Immobilienservice ohG, 1997 E.C.R. 2195, II 28, [1997] 3 C.M.L.R. 1107, 1126 (1997) (holding that German law implementing Directive 76/207, which placed a ceiling on compensation of three months' earnings not provided for by other provisions of domestic civil and labor law, violated nondiscrimination principle); Cases 66, 127 \& 128/79, Ammistrazione delle Finanze v. S.r.l. Meridionale hdustria Salumi, 1980 E.C.R. 1237, IIII 20-21, [1981] 1 C.M.L.R. 1, IIII 20-21 (1980) (holding that national rules governing collection of Community charges and dues that restrict ability of national authority to collect relative to powers for national charges and duties, violate nondiscrimination principle).

Draehmpaehlalso demonstrates the potential weakness of the nondiscrimination principle in practice. Under the German law implementing the Equal Treatment Directive, an individual applicant suffering gender discrimination in employment could recover a maximum of three months' lost earnings - a cap unlike any imposed for infringements of similar domestic law. The Court of Justice concluded that, in principle, such a restriction violated both the principles of effective judicial protection and nondiscrimination. But in response to the order of reference, the Court indicated that Member States could, for individuals who would not have obtained the position in question in any event, create a "statutory presumption" limiting compensation to three months' salary. Draehmpaehl v. Urania Immobilienservice ohG, 1997 E.C.R. at III 28-37, [1997] 3 C.M.L.R. 1107 at IIII 28-37. The possibility of such subdivisions clearly undermined the force of the nondiscrimination principle. See also Cases 66, 127 \& 128/79, Ammistrazione delle Finanze v. S.r.l. Meridionale Industria Salumi, 1980 E.C.R. 1237, II 18, [1981] 1 C.M.L.R. 1, II 18 (1980) (combining effectiveness and nondiscrimin ation inquiries).

84. See Case 33/76, Rewe-Zentral-" nanz, 1976 E.C.R. at II 5; Case 265/78, Ferwerda v. Produktschap voor Vee en Vlees, 1980 E.C.R. 617, II 10, [1980] 3 C.M.L.R. 737 (1980). The phrasing of the standard sometimes varied. See, e.g., Case 13/68, Salgoil v. Italian Ministry for Trade, 1968 E.C.R. 453, 468, [1969] C.M.L.R. 181, 196 (1968) (Member States responsible for ensuring that national courts provide "direct and immediate protection"); Case 199/82, Amminstrazione delle Finanze dello Stato v. San Giorgio, 1983 E.C.R. 3595, đ[ 14, [1985] 2 C.M.L.R. 658 (1983) (national law cannot make securing Community law right "virtually impossible or excessively difacult"); Case 179/84, Bozzetti v. Invernizzi, 1985 E.C.R. 2301, II 17, [1986] 2 C.M.L.R. 246, II 17 (1985) (Member States responsible for ensuring that rights established by regulation are "effectively protected in each case."); Case 222/86, UNECTEF v. Heylens, 1987 E.C.R. 4097, II 10, [1989] 1 C.M.L.R. 901, II 10 (1987) (Community workers entitled to fundamental right under Treaty "must also be able to defend that right under the best possible conditions ...").

85. See, e.g., Case 14/83, Von Colson and Kamann v. Land Nordrhein-Westfalen, 1984 E.C.R. 1891, II 24, [1986] 2 C.M.L.R. 430, II 24 (1984); Case 79/83, Harz v. Deutsche Tradax 
standing, ${ }^{86}$ the evidence necessary to establish a remedy (and overcome defenses),${ }^{87}$ retroactivity, ${ }^{88}$ waiver, ${ }^{89}$ jurisdiction, ${ }^{90}$ or periods of limitations ${ }^{91}$ might unduly frustrate Community rights. On the other hand, so-called reasonable national rules, such as certain periods of limitations, ${ }^{92}$ waiver,${ }^{93}$ jurisdiction, ${ }^{94}$ assigning liability, ${ }^{95}$

GmbH, 1984 E.C.R. 1921, If 24, [1986] 2 C.M.L.R. 430, If 24 (1984).

86. See, e.g., Case 87-89/90, Verholen v. Sociale Verzekeringsbank Amsterdam, 1991 E.C.R. 3757, IIII 23-24, [1994] 1 C.M.L.R. 157, IIII $23-24$ (1991) (dicta).

87. See, e.g., Case 199/82, Amminstrazione delle Finanze dello Stato v. San Giorgio, 1983 E.C.R. 3595, III 14, 18, [1985] 2 C.M.L.R. 658, TIII 14, 18 (1983) (national law permitting claimant to recover health inspection charges unlawfully levied only where claimant satis ${ }^{\mathrm{a} e d}$ burden of proving that such charges had not been passed on to other persons, or excluding evidence other than documentary evidence, made it "virtually impossible or excessively dif cult" to secure repayment).

88. See, e.g., Case 309/85, Barra v. Belgium, 1988 E.C.R. 355, III 19-20, [1988] 2 C.M.L.R. 409, IIII 19-20 (1988) (national legislation limiting repayment of foreign students' enrollment fees (minervals) to cases aled prior to Court of Justice judgment holding fees unlawful itself violates Community law by rendering "impossible" exercise of rights conferred by Treaty); Case 240/87, Deville v. Administration des Impôt, 1988 E.C.R. 3513, TII 12-13, [1989] 3 C.M.L.R. 611, TII 12-13 (1988) (national legislature may not, subsequent to Court of Justice judgment invalidating national legislation, adopt or make applicable procedural rule reducing the prospect for bringing timely proceedings for recovery of taxes wrongly levied under invalidated legislation).

89. See, e.g., Case C-312/93, Peterbroeck, Van Campenhout \& Cie SCS v. Belgium, 1995 E.C.R. I-4599, [1996] 1 C.M.L.R. 793 (1995) [hereinafter Peterbroeck] (domestic procedural rule preventing Belgian Cour d'Appel from considering on its own motion whether compat ibility of national measure with a Community law provision that litigant had not timely raised was incompatible with Community law where circumstances limited ability of applicant to raise issue before court entitled to make reference to Court of Justice; no other national court or tribunal could in subsequent proceedings raise the compatibility issue; and rule against sua sponte invocation by court not justiaed by persuasive legal principles).

90. See, e.g., Case 106/77, Amministrazione delle Finanze dello Stato v. Simmenthal SpA (No. 2), 1978 E.C.R. 629, II 22, [1978] 3 C.M.L.R. 263, II 22 (1978) (holding that national courts must set aside national rules "which might impair the effectiveness of Community law by withholding from the national court having jurisdiction to apply such law the power to do everything necessary at the moment of its application to set aside national legislative provisions which might prevent Community rules from having full force and effect"). Simmenthal was occupied with matters of supremacy only tangentially related to national remedies- the $c^{\circ}$ ict in question was between Community regulations and subsequently enacted Italian legislation, and whether an Italian court must seek the judgment of a special constitutional court to eliminate that con ${ }^{\circ}$ ict. See Stein, supra note 46, at 13-14 (analyzing Simmenthal and supremacy). But see Garcia, supra note 79, at 198 (describing how continental lawyers would consider the issue remedial in nature). In asserting that Community law might invest national courts with powers they otherwise lacked, Simmenthal "remained an isolated case ... for the next 12 years until the judgment in Factortame was given, which again raised comparable problems." Prechal, supra note 43, at 156.

91. See Case 309/85, Barra v. Belgium, 1988 E.C.R. 355, [1988] 2 C.M.L.R. 409 (1988); Case 240/87, Deville v. Administration des Impôt, 1988 E.C.R. 3513, [1989] 3 C.M.L.R. 611 (1988). In Case C-208/90, Emmott v. Minister for Social Welfare, 1991 E.C.R. I-4269, the Court held that Ireland was precluded from relying on a national rule limiting the time for initiating proceedings for so long as it had failed properly to transpose the underlying directive into its national legal system. Subsequent case law called the broad language of Emmott into question. See Hoskins, Tilting the Balance, supra note 39, at 367-72 (criticizing Emmott and attempted distinction in later cases); Ward, supra note 28, at 210-12.

92. See Case 33/76, Rewe-Zentral- " nanz, 1976 E.C.R. 1989, 1993, [1977] 1 C.M.L.R. 533 (1976) (limitations periods may bar claims to restitution arising under Community law where 
interest and interest rates, ${ }^{96}$ and permitting defenses such as setoff, ${ }^{97}$ unjust enrichment, ${ }^{98}$ or the protection of legitimate expectations and legal certainty, ${ }^{99}$ and allowing severance of illegal clauses, ${ }^{100}$ could be left to the discretion of Member States' national courts and their national legal systems.

Perhaps aware that these decisions were impossible to reconcile, ${ }^{101}$ in the mid-1980s, the Court began to grasp for a different

nondiscriminatory and not rendering practice of Community law rights impossible in practice); see, e.g., Case C-88/95, Fantask A/S v. Industriministeriet (Ehrverministeriet), 1997 E.C.R. I-6783, III 42-52, [1998] 1 C.M.L.R. 473 (1998) (upholding application of Danish ${ }^{a}$ ve-year limitations period as applied to corporate registration fees); Case C-261/95, Palmisani v. INPS, 1997 E.C.R. I-4025, IITI 28-29, [1997] 3 C.M.L.R. 1356, IITI 28-29 (1997) (one-year time limit for bringing proceedings for compensation under retroactive, but tardy, implementation of directive does not make claim for reparation impossible or excessively dif ${ }^{\mathrm{a}}$ cult).

93. See, e.g., Cases C-430 \& C-431/93, van Schinjdel, 1995 E.C.R. I-4705, [1996] 1 C.M.L.R. 793 (1995) (Community law does not require national courts to raise issue involving breach of Community law provisions where intervention would interject court into adversary process of civil litigation).

94. See, e.g., Case 13/68, Salgoil v. Italian Ministry for Trade, 1968 E.C.R. 453, 462-63, [1969] C.M.L.R. 181, 196-97 (1968) (while Community law entitled Community citizen to import license, Member States retained discretion to classify legal interest for purposes of allocating jurisdiction among national courts, unless undermining "direct and immediate protection" of the claimants' interests).

95. See, e.g., Case C-114 \& 115/95, Texaco A/S v. Middelfort Havn, 1997 E.C.R. I-4263, IIII 41-42 (national law may determine whether action for recovery of unlawful duties lies against independent operators subject to local control to whom proceeds have been allocated, against state, or both, subject to effectiveness and nondiscrimination principles).

96. See, e.g., Case 130/79, Express Dairy Foods, 1980 E.C.R. 1887, IITI 16-17, [1981] 1 C.M.L.R. 451, IIII 16-17 (1980); Case 6/60, Humblet v. Belgium, 1960 E.C.R. 559, 569. But see Case C-271/91, Marshall v. Southhampton and South-West Hampshire Health Authority, 1993 E.C.R. I-4367, [1993] 3 C.M.L.R. 293 (1993) [hereinafter Marshall II].

97. See, e.g., Case 177/78, Pigs \& Bacon Commission v. McCarren \& Co. Ltd., 1979 E.C.R. 2161, TIIT 25-26, [1979] 3 C.M.L.R. 389, IIII 25-26 (1979) (national court may determine, pursuant to national law, whether and to what extent levy improperly demanded of trader must be reimbursed and whether and to what extent reimbursement may be offset by export bonuses paid to trader).

98. See, e.g., Case 68/79, Hans Just I/S v. Danish Ministry for Fiscal Affairs, 1980 E.C.R. 501, IIII 17-27, [1981] 2 C.M.L.R. 714, III 17-27 (1980) (national law permitting defense of unjust enrichment, and deduction from taxes wrongfully paid of amounts passed on to consumers, is compat ible with Community law).

99. Such defenses enable private parties to assert a reliance interest against the enforcement of Community law-for example, reliance on a Community subsidy that had been unlawfully tendered by a national authority, see Cases 205 to 215/82, Deutsche Milchkontor GmbH v. Germany, 1983 E.C.R. 2633, 2669-70, or illegal state aid, see Case C-5/89, Co mmission v. Germany, 1990 E.C.R. I-3437, 3456-57. Deutsche Milchkontor also suggested that so long as the Community interest in recovery was given adequate weight, and nondiscrimination principles satis ${ }^{\mathrm{a}} \mathrm{d}$, restitution might also be contraindicated by the loss of the money in question, the passing of a time-limit, or the fact that the national administration knew or had cause to know that it was wrong in granting the aid. 1983 E.C.R. at 2668-69.

100. See, e.g., Case 56/65, Société La Technique Minière v. Maschinenbau Ulm, 1966 E.C.R. 235, 245-46, [1966] C.M.L.R. 357, 376-77 (1966).

101. Three brief examples illustrate. First, the Court gave little guidance as to why certain limitations periods made it "impossible" to exercise Community law rights while others did not. Other national procedural rules, too, could have a similar effect: for example, the rattional schemes in Salgoil also gave rise to the prospect that a claim might be forfeited if 
approach altogether, one founded more explicitly on the protection of individual rights. ${ }^{102}$ In Von Colson, ${ }^{103}$ the Court derived a principle of "effective judicial protection" from the Equal Treatment Directive. ${ }^{104}$ Over the next several years, the Court parlayed that approach from one grounded in the directive's text, into a "fundamental right of private parties," to effective judicial remedies for the breach of Community law rights. ${ }^{105}$

initially aled before the wrong court and not remedied before the end of the limitations period. See Case 13/68, Salgoil, 1968 E.C.R. at 468, [1969] C.M.L.R. at 196.

Similarly, the Court's determination that some evidentiary rules excessively impaired Community rights tended to contradict case law permitting Member States to allow the same defenses without any regard for matters of proof. Compare Case 199/82, Amminstrazione delle Finanze dello Stato v. San Giorgio, 1983 E.C.R. 3595, [1985] 2 C.M.L.R. 658 (1983) with Case 68/79, Hans Just I/S v. Danish Ministry for Fiscal Affairs, 1980 E.C.R. 501, [1981] 2 C.M.L.R. 714 (1980).

Finally, as noted further below, the Court's decisions concerning the responsibility of state courts to raise issues of Community law sua sponte, though rendered on the same day, do not refer to one another, are not reconcilable as explained, and can only be speculatively distinguished. See infra note 210. Compare Case C-312/93, Peterbroeck, 1995 E.C.R. I-4599, [1996] 1 C.M.L.R. 793 (1995), with Case C-430 \& C-431/93, van Schijndel, 1995 E.C.R. I4705, [1996] 1 C.M.L.R. 801 (1995).

102. See Prechal, supra note 43, at 160; Lewis, supra note 46, at 55-58; Josephine Steiner, Enforcing EC Law 43, 44-45 (1995); Christopher Harding, Member State Enforcement of European Community Measures: The Chimera of 'Effective' Enforcement, 4 Maastricht J. Eur. \& Comp. L. 5, 7 (1997) (Court of Justice has become "increasingly incursive" in asessing appropriateness of national measures).

103. Case 14/83, Von Colson and Kamann v. Land Nordrhein-Westfalen, 1984 E.C.R. 1891, I[23, [1986] 2 C.M.L.R. 430 (1984).

104. Directive 76/207 on the Implementation of the Principle of Equal Treatment for Men and Women as Regards Access to Employment, Vocational Training and Promotion, and Working Conditions, 1976 O.J. (L 39) 40 [hereinafter Equal Treatment Directive]. In Von Colson, the Court acknowledged that the directive's terms did not require any specia ${ }^{\mathrm{a}} \mathrm{c}$ form of sanction, and thus did not obligate Member States to require employers to hire job candidates against whom they had discriminated. But given the directive's emphasis on judicial process, the Court cautioned that any sanction chosen must "guarantee real and effective judicial protection ... [and] must also have a real deterrent effect on the employer." 1984 E.C.R. 1891, [1986] 2 C.M.L.R. 430 (1984)

Applying this standard, the Court found, unsurprisingly, that candidates suffering unlawful discrimination should not be limited to recovering their application fees. See Tash, supra note 76, at 389 (language of Equal Treatment Directive "does no more than capture the principle of effectiveness in legislative form") (citing P. Oliver, Enforcing Community Rights in the English Courts, 50 Mod. L. Rev. 881, 882 (1987)).

For a fuller description of the Court of Justice's jurisprudence concerning equal treatment, and the Commission's efforts in the same aeld, see Christopher McRudden, The Effectiveness of European Equality Law: National Mechanisms for Enforcing Gender Equality Law in the Light of European Requirements, 13 Oxford J. Leg. Stud. 320 (1993).

105. Lenaerts, supra note 37, at 100; see also Angela Ward, New Frontiers in Private Enforcement of E.C. Directives, 23 Eur. L. Rev. 65, 70 (1998) (suggesting that "the right of private parties to real and effective judicial protection, and a remedy that supplies a real deterrent effect against breach, is not restricted to cases in which reliance is placed on the equal treatment directives"); Case 222/84, Johnston v. Chief Constable of the Royal Ulster Constabulary, 1986 E.C.R. 1663, [1986] 3 C.M.L.R. 240 (1986); Case 222/86, UNECTEF v. Heylens, 1987 E.C.R. 4097, II 14, [1989] 1 C.M.L.R. 901 (1987). In Johnston, the Court described the Equal Treatment Directive's "requirement of judicial control" as a general constitutional principle re $\mathrm{e}^{\circ}$ ected in the European Convention for the Protection of Human Rights and Fundamental Freedoms, to which the Community was not a party. Johnston, 1986 
Numerous commentators have tried to explain the evolution from the "impossibility" test for effectiveness to effective judicial protection, and to invent doctrinal explanations for the apparent inconsistencies and abscesses among and within those doctrines. But most resort to extrinsic explanations-usually, accounts balancing the Court's inclination to promote Community-law rights against the constraints imposed by the Member States and their national legal systems. ${ }^{106}$ To the extent the case law coheres, it may be seen to evidence the Court's concern with identifying occasions on which the Member States charged with implementing Community law were most likely to behave opportunistically. The effectiveness cases, for the most part, involved money matters in which national self-interest was patent; ${ }^{107}$ the most intrusive effective judicial protection decisions, likewise, concerned relatively blatant instances of con $^{\circ}$ ict between unchecked state self-interest and individual rights. But this rationalization was severely damaged by subsequent case law creating new Community law remedies. ${ }^{108}$

\section{Implied Community Law Remedies}

The most basic premise of the Rewe-Zentral-'nanz/Comet approach was that the EC Treaty "was not intended to create new remedies in the national courts to ensure the observance of Com-

E.C.R. 1663 at $\mathbb{~ I [ ~ 1 8 , ~ [ 1 9 8 6 ] ~} 3$ C.M.L.R. 240.

In Case C-377/89, Cotter \& McDermott v. Minister for Social Welfare, [1991] 3 C.M.L.R. 507, the Court of Justice rejected a more general argument premised on unjust enrichment principles - namely, Ireland's contention that granting married women (as well as married men) automatic increases in social security bene ats for family members presumed to be dependents might permit double recovery for families in which both spouses received beneats. Id. at IIII 20-22. According to the Court, "[t]o permit reliance on that prohibition would enable the national authorities to use their own unlawful conduct as a ground for depriving Article 4(1) of the directive of its full effect." Id. at II 21.

106. For an exemplary discussion, see Smith, supra note 76.

107. The claims tended to fall into one of three categories: (1) claims seeking reimbursement of payments exacted contrary to Community law; (2) claims regarding sums not paid as required by Community law; and (3) claims for refunds of sums mistakenly paid out on behalf of the Community. See John Bridge, Procedural Aspects of the Enforcement of European Community Law Through the Legal System of the Member Sates, 9 Eur. L. Rev. 28, 32 (1994) (citing cases); see also Prechal, supra note 43, at 152.

108. Johnston, 1986 E.C.R. 1663, [1986] 3 C.M.L.R. 240 (1986), involved the order implementing the Equal Treatment Directive for Northern Ireland, which provided that none of its antidiscrimination provisions were to "render unlawful an act done for the purpose of safeguarding national security or of protecting public safety or public order," and that a certia cate to that effect signed by the Secretary of State was to be "conclusive evidence" for those purposes. 1986 E.C.R. at 1677, [1986] 3 C.M.L.R. at 258 (1986). The Chief Constable of the Royal Ulster Constabulary refused to renew the contract of a uniformed police of ${ }^{\mathrm{a}} \mathrm{cer}$ based on a blatantly discriminatory policy precluding women of ${ }^{a}$ cers from duty requiring the carrying of ${ }^{a}$ rearms. In the course of litigation, the Chief Constable introduced a certia ${ }^{\mathrm{a}}$ cate issued by the Secretary of State duly declaring that the employment decision had been done for the purposes of safeguarding national security and protecting public safety and order. 
munity law, other than those already laid down by national law."109 Two notable exceptions to this approach, Community rights to restitution and injunctive relief, presage Francovich both in their degree of intrusiveness and in their commitment to effective judicial protection. But as made clear below, these remedies also blossomed in the most attractive context for Community intervention-where the Community interest was apparent from directly applicable, directly effective rights, and the national interest was compromised by the prospect for Member State self-dealing.

\section{a. Restitution}

The Court of Justice long assumed that there was a right to restitution of monies obtained through unlawful taxes or import duties, ${ }^{110}$ but left it unclear whether that right arose under Community law or was simply a common feature of Member States' national

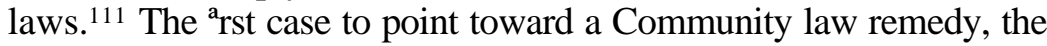
Pigs \& Bacon judgment, suggested obliquely that doing otherwise would permit Member States to prot from their wrongdoing. ${ }^{112}$ Thus framed, restitution was founded less on the need for individual redress than on the need to disgorge the proceeds from the appropriating Member State-an argument that taps at the unjust enrichment core of the restitution principle. ${ }^{113}$

109. Case 158/80, Rewe-Handelsgesellschaft Nord MbH v. Hauptzollamt Kiel, 1981 E.C.R. 1805, II 44 [1982], C.M.L.R. 449, II 44 (1981) ; see also Josephine Steiner, How to Make the Action Suit the Case: Domestic Remedies for Breach of EEC Law, 12 Eur. L. Rev. 102, 103 (1987) ("EEC law does not prescribe the remedy, nor require that new remedies should be provided; it merely demands that parties should have recourse to the same remedies and procedures as are available in similar actions of a domestic nature.").

110. See Case 6/60, Humblet v. Belgium, 1960 E.C.R. 559, 581; see also Steiner, supra note 102 , at $46-47$.

111. The judgment in Rewe-Zentral-ananz, for example, posed but avoided answering the national court's question of "whether . . . a right to refund is held to exist under Community law." Opinion of Advocate General Warner, Case 33/76, Rewe-Zentral- "nanz, 1976 E.C.R. at 1997, 1998, [1977] 1 C.M.L.R. at 550, 551. If anything, the earliest indications were that remedies were left entirely to Member States. See Schermers \& Waelbroeck, supra note 53, $\S 190$ (suggesting that restitution continues to be dependent on national law); Lesley Jane Smith, A European Concept of Condictio Indebiti? , 19 Common Mkt. L. Rev. 269 (1982).

112. According to the Court, any trader required to pay a levy "has therefore the right to claim the reimbursement of that part of the levy which is thus devoted to purposes incompatible with Community law." The Court continued: "However, it is for the national court to assess, according to its national law, in each individual case, whether and to what extent the levy paid may be recovered and whether there may be set off against such a debt the sums paid to a trader by way of export bonus." Case 177/78, Pigs \& Bacon Comm'n v. McCarren \& Co. Ltd., 1979 E.C.R. 2161, đ[25, [1979] 3 C.M.L.R. 389, II 25 (1979).

113. See Peter Birks, Introduction to the Law of Restitution 17 (1985) (describing unjust enrichment as the "causative event," and restitution the "response"); $c f$. Andrew Kull, Rationalizing Restitution, 83 Cal. L. Rev. 1191 (disputing restoration-based theories of restit u tion); Douglas Laycock, Restitution, 67 Tex. L. Rev. 1277, 1279-83 (1989) (discussing restitution as a concept of unjust enrichment, and rival usage as meaning restoration in kind of a speciac thing). 
A series of Advocate General opinions later proposed that drectly effective provisions barring the demand for payment necessarily entailed the right to recover any monies unlawfully tendered, ${ }^{114}$ and this line of analysis was ${ }^{a}$ nally adopted by the Court in its San Giorgio judgment. ${ }^{115}$ Direct effect, as conventionally understood, did not necessarily mean that an individual who had paid unlawful charges should recover those charges in full. ${ }^{116}$ But the shift toward an estoppel theory of direct effect made San Giorgio's reasoning more like the self-interest concerns hinted at by Pigs \& Bacon. The national rule in San Giorgio, one barring restitution unless the claimant could show that the unlawful charge had not been passed on to purchasers, did not merely interfere with the exercise of a Community right, but directly inured to the bene ${ }^{a} t$ of the government charged with establishing the enforcement mechanism. Self-interest was inherent to restitution cases-either because Member State rules allowed them to retain money unlawfully collected, or permitted their nationals to retain Community monies or unlawful state aid - as was reflected in national law erecting special barriers to restitution claims against the government. ${ }^{117}$ In several

114. See Opinion of Advocate General Reischl, Case 68/79, Hans Just I/S v. Danish Ministry for Fiscal Affairs, 1980 E.C.R. 501, 530-31, [1981] 2 C.M.L.R. 714, 724 (1980); Opinion of Advocate General Reischl, Case 61/79, Amministrazione delle Finanze dello Stato v. Denkavit Italiana Srl, 1980 E.C.R. 1205, 1232-33, [1981] 3 C.M.L.R. 694, 699-700 (1980); Opinion of Advocate General Reischl, Case 77/76, Fratelli Cucchi v. Avez S.p.A., 1977 E.C.R. 987, 1011.

115. Case 199/82, Amministrazione delle Finanze dello Stato v. S.p.A. San Giorgio, 1983 E.C.R. 3595, I[ 12, [1985] 2 C.M.L.R. 658, II 12 (1983) ("[I]t must be pointed out in the arst place that entitlement to the repayment of charges levied by a Member State contrary to the rules of Community law is a consequence of, and an adjunct to, the rights conferred on individuals by the Community provisions prohibiting charges having an effect equivalent to customs duties or, as the case may be, the discriminatory application of internal taxes.").

116. Indeed, just a few years prior to San Giorgio, the Court had cautioned that even where Community law prohibited a national charge or dues, safeguarding directly effective rights "does not necessarily require a uniform rule common to Member States relating to the formal and substantive conditions to which the contesting or recovery of those very diverse national charges is subject." Case 811/79, Amministrazione delle Finanze dello Stato v. Ariete SpA, 1980 E.C.R. 2545, II 9, [1981] 1 C.M.L.R. 316, II 9 (1980).

117. National laws varied, and even varied within national systems based on the type of charges at issue. See Unjustifed Enrichment: A Comparative Study of the Law of Restitution (Paul W. L. Russell ed., 1996) (summarizing restitution laws of the Netherlands, England, Germany, and France); Allan F. Tatham, Restitution of Charges and Duties Levied by Public Administration in Breach of European Community Law: A Comparative Analysis, 19 Eur. L. Rev. 146 (1994) (comparing laws of European Community, England, France, and Italy). But one recurrent theme was the resistance to a right of restitution against public authorities. See Brealey \& Hoskins, supra note 39, at 104-05 (English law); Tatham, supra, at 149-54 (noting that while English common law ostensibly treated government on equal footing, absent Community law and its in ${ }^{\circ}$ uence, statutory law limited recovery); $i d$. at 159-62 (concluding that, absent Community law standards, Italian law made recovery of duties practically impossible). Furthermore, European law continues to provide, in varying degrees, that the restit ution remedy is one of last resort. See Eltjo Schrage, Restitution in the New Dutch Civil Code, in Unjustia ed Enrichment, supra, at 40-42 (surveying Italian, French, German, Dutch, and English laws of restitution); accord Barry Nicholas, Modern Developments in the French 
cases, indeed, Member States appeared to have revised national law in order to discriminate against the Community rights in question. ${ }^{118}$ Such conduct was dif ${ }^{a}$ cult to address within the framework of the nondiscrimination and effectiveness principles, given the lack of any discrepancy between the treatment of national and Community law claims. Under the circumstances, the cooperative enterprise suggested by the Court's early vision of Article 10 (ex art. 5) seemed worth enforcing by a Community remedy.

\section{b. Interim Relief Against Member States}

Perhaps because it was expressly given jurisdiction to grant interim relief in cases involving Community institutions, the Court seems to have assumed that it could grant interim relief against Member States. ${ }^{119}$ The Factortame case presented, apparently for

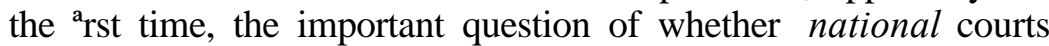
were compelled to provide such relief in comparable circumstances. ${ }^{120}$ At issue was an attempt by the United Kingdom to redress the "plundering" by Spanish-owned vessels of the U.K. " sh quota by restricting registration based on the nationality, residence, and domicile of owners. Because the English courts were uncertain of their ability to invalidate acts of Parliament and grant injunctions against the Crown, they asked the Court of Justice whether Com-

Law of Unjusti ${ }^{a}$ ed Enrichments, in Unjustia ${ }^{a}$ ed Enrichment, supra, at 77, 87-93. European governments are scarcely alone in manifesting this type of reluctance. See Saul Levmore, Explaining Restitution, 71 Va. L. Rev. 65, 93-94 \& n.63 (1985).

118. Barra, for example, involved Belgian legislation that had limited the possibility of recovering minervals to cases aled before the date of the Court's judgment invalidating those fees-legislation adopted following that judgment, and during subsequent proceedings brought by the Barra plaintiffs. See Opinion of Advocate General Slynn, Case 309/85, Barra v. Belgium, 1988 E.C.R. 355, IITI 19-20, [1988] 2 C.M.L.R. 409, TII 19-20 (1988); see also Case 293/85, Commission v. Belgium, 1988 E.C.R. 305, [1989] 2 C.M.L.R. 527 (1988). Deville likewise considered French legislation that that imposed special time limitations pertaining to claims made after the relevant Court of Justice judgment. See Opinion of Advocate General Slynn, Case 240/87, Deville v. Administration des Impôt, 1988 E.C.R. 3513, IIII 12-13, [1989] 3 C.M.L.R. 611, IIII 12-13 (1988). And San Giorgio confronted Italian recognition of the "passing on" defense that seemed to depart from the general provisions of the Italian code, see Opinion of Advocate General Mancini, Case 199/82, Amminstrazione delle Finanze dello Stato v. San Giorgio, 1983 E.C.R. 3595, [1985] 2 C.M.L.R. 658, 673 (1983), and was arguably unknown to Member States other than Denmark prior to the Court's decision in Hans Just. Id. at 677, 678-79. See also Dubinsky, supra note 4, at 32830; Smith, supra note 76, at 298.

119. See EC Treaty art. 243 (ex art. 186). Such authority gives the Court substantially more power than it possesses in anal judgments, where it is con ${ }^{a}$ ned to issuing declaratory orders. See Hartley, supra note 6, at 324-28; see also Schermers \& Waelbroeck, supra note 53 , at $\$ \S 823-829$ a.

120. As the Advocate General noted, on several previous occasions national courts voluntarily granted interim measures that effectively suspended national law during the pendency of Court of Justice proceedings. See Opinion of Advocate General Tesauro, Case C213/89, Factortame, 1990 E.C.R. I-2433, 2455 n.6, [1990] 3 C.M.L.R. 375 (1990). On the other hand, French courts had proven reluctant to do so. Id. at 2455 n.7. 
munity law empowered (or obliged) an English court to issue interim relief, and when. ${ }^{121}$

The Court invoked its earlier, little employed decision in Simmenthal, which held that national courts must set aside national rules that withhold from national courts having jurisdiction "the power to do everything necessary ... to set aside national legisative provisions which might prevent Community rules from having full force and effect." 122 Having resuscitated Simmenthal, the Court spent just two sentences extending it, holding that full effectiveness of Community law rights would also be impaired if national law were to prevent a court from granting interim relief to which it was otherwise inclined. 123

The Court's holding was actually rather narrow. ${ }^{124}$ Disregarding the House of Lords' questions, ${ }^{125}$ the Court did not specify the con-

121. See R. v. Secretary of State for Transport ex parte Factortame Ltd. (2), [1990] 2 A.C. 85 (House of Lords). The divisional court earlier had referred to the Court of Justice the question of the compatibility of the 1988 Act with EC law, see Ex parte Factortame, [1989] 2 C.M.L.R. at 371, eventually resulting in a decision that the nationality and residence requirements in U.K. law violated Community law. See Case C-221/89, R. v. Secretary of State for Transport ex parte Factortame Ltd., [Factortame I], 1991 E.C.R. I-3905, [1991] 3 C.M.L.R. 589 (1991). The Commission initiated separate Article 169 proceedings and dbtained an interim order requiring the United Kingdom to suspend application of the nationality requirements. See Case C-246/89R, Commission v. United Kingdom (Re. Nationality of Fisherman), 1989 E.C.R. 3125, [1989] 3 C.M.L.R. 601 (1989). In a continuation of those proceedings, the Court found against the United Kingdom. See Case C-246/89, Commission v. United Kingdom (Re. Nationality of Fisherman), 1991 E.C.R. I-4585, [1991] 3 C.M.L.R. 706 (1991). Cf. Case C-3/87 Regina v. Ministry of Agriculture, Fisheries \& Food, ex parte Agegate Ltd., 1989 E.C.R. 4459, [1990] 1 C.M.L.R. 366 (1990) (upholding national rule requiring social security contributions, but holding that Community law precluded condition requiring 75\% of crew to reside ashore in United Kingdom); Case C-216/87, Regina v. Ministry of Agriculture, Fisheries \& Food, ex parte Jaderow Ltd., 1989 E.C.R. 4509, [1991] 2 C.M.L.R. 556 (1991) (upholding validity of operating conditions requiring economic link between vessels and United Kingdom).

122. Case C-106/77, Amministrazione delle Finanze dello Stato v. Simmenthal S.p.A. (No. 2), 1978 E.C.R. 629, I[ 22, [1978] 3 C.M.L.R. 263, II 22 (1978); see supra note 90 (discussing Simmenthal).

123. Case C-213/89, Factortame, 1990 E.C.R. I-2433, 2474, [1990] 3 C.M.L.R. 375 (1990). The Court buttressed the need for protective jurisdiction by citing the Article 234 (ex art. 177) referral mechanism: were a national court to stay its proceedings pending an answer from the Court of Justice, but remain helpless in the interim, the effectiveness of the preliminary reference would be undermined. See id. at II 22. But surely the preliminary ruling might have been preserved by less drastic means. For example, the Court might have determined to resolve such cases regardless of their status before the national courts, and irrespective of potential mootness concerns. Likewise, the Court might preserve jurisdiction by granting interim relief in its own right, thereby reducing the harm to the potential applicants. But see Oliver, supra note 51, at 9-10 (noting that "[t]he Court has never been called upon to decide whether it may grant interim measures in cases referred to it for a preliminary ruling," and questioning basis for such authority). Taking the Court's Article 177 argument at face value, though, the Community interest in preserving preliminary references suggests a need to dictate minimum conditions under which interim relief would have to be granted. See also Chalmers, supra note 60, at 187 (describing, and defending, Court's protection of Article 177 jurisdiction).

124. See Curtin \& Mortelmans, supra note 30, at 438 ("Factortame I can be regarded as 
ditions under which interim relief should be granted, leaving open the possibility that only those rules severely limiting judicial discretion, or insulating the sovereign, were objectionable under Community law. ${ }^{126}$ Though the case surely represented the Court's farthest reach into the law of remedies, ${ }^{127}$ to all appearances the Court's decision essentially reaf ${ }^{a}$ rmed the implications of supremacy for Member States, without attempting to divine the principle's scope. ${ }^{128}$

This narrow interpretation was undermined by a contemporary to Francovich, the Zuckerfabrik judgment, ${ }^{129}$ which concerned the distinct issue of whether and when a national court should enjoin a

intended to interfere with the system of domestic remedies and procedures to the least possible extent.") (emphasis in original). The Court's decision was even read to require national courts to set aside rules preventing them from granting interim relief without actually requiring them to create such a remedy if it did not exist. This seems implausible and somewhat purposeless. See Oliver, supra note 51, at 16; see also infra text accompanying note 133 (discussing Zuckerfabrik).

125. In its principal question, the House of Lords had carefully hypothesized a case in which, among other things, "there are serious arguments both for and against the existence of the [Community] rights claimed." The Court considered this as raising "whether a national court which, in a case before it ... considers that the sole obstacle which precludes it from granting interim relief is a rule of national law, must disapply that rule." Compare Case C213/89, Factortame, 1990 E.C.R. I-2433, 2472-73, [1990] 3 C.M.L.R. 375 (1990) (reciting questions posed by House of Lords) with id. at 2474; for criticisms of the Court's reformulation, see Papadias, supra note 71, at 171; Ami Barav, Interim Relief and English Law, 140 New L.J. 896, 899 (1990); Ami Barav, Omnipotent Courts, in Institutional Dynamics of European Integration, supra note 12, at 270-77. That reformulation, however, is in keeping with the Court's limited role under Article 177 (ex art. 234), and is at least consistent with the Court's disinclination to answer the House of Lords' second question as to the conditions governing the grant of interim relief. But see Papadias, supra note 71, at 173-74, 176-77 (criticizing failure to address second question posed by House of Lords).

126. See Opinion of Advocate General Tesauro, Case C-213/89, Factortame, 1990 E.C.R. I-2433, 2464, [1990] 3 C.M.L.R. 375 (1990) (proposing that Court reply to House of Lords' second question by declaring that national law governs conditions for interim relief); Papadias, supra note 71, at 175 (concluding that Factortame implies that criteria to be employed are those of national law); Jacques Algazy, The Crown, Interim Relief and EEC Law, 141 New L.J. 1303, 1304 (1991) (arguing that Factortame injunctions, unlike Zuckerfabrik injunctions, were governed by national criteria); Oliver, supra note 51, at 17 (advocating pproach recommended by Advocate General Tesauro).

127. See, e.g., Papadias, supra note 71 , at 170 ("Factortame presumably is going to be ranked amongst the most important 'constitutional' cases of the Court of Justice with regard to the evolution and reinforcement of the Community legal order."); $i d$. at $170 \mathrm{n} .55$ (citing support).

128. See, e.g., Barav, Omnipotent Courts, supra note 125, at 274 ("[T] he European Court, reducing the matter to a banal issue of supremacy, regarded the question in Factortame as a matter of exercise of power, whereas the real and crucial question was that of its very existence."); see also R. v. Secretary of State for Transportex parte Factortame Ltd. (2), [1991] 1 A.C. at 658G-659C, [1991] 1 All E.R. at 107j-108c (Lord Bridge). Lord Bridge also stressed that "[a]lthough af $\mathrm{f}^{\mathrm{r}} \mathrm{rming}$ our jurisdiction, the judgment of the European Court of Justice does not fetter our discretion to determine whether an appropriate case for the grant of interim relief has been made out." Id. at [1991] 1 A.C. at 659C, [1991] 1 All E.R. at 108d.

129. Joined Cases C-143/88 \& C-92/89, Zuckerfabrik Süderdithmarschen AG v. Hauptzollamt Itzehoe, 1991 E.C.R. I-415. 
Community regulation. ${ }^{130}$ In elaborating standards for such relief, ${ }^{131}$ the Court appeared to suggest that the same conditions should govern interim relief against national measures, since in both cases the underlying dispute concerned Community law. ${ }^{132}$ Even if that takes the decision too literally, ${ }^{133}$ Zuckerfabrik indisputably extended the rationale of Factortame beyond mere supremacy. According to the Court, Community law made paramount the right of individuals to challenge Community measures, and that right would be unduly compromised if individuals could not achieve interim relief while awaiting judgment by the Court of Justice. ${ }^{134}$ That emphasis plainly anticipated Francovich. ${ }^{135}$

130. More speciacally, a national tax was imposed in accord with a Community regulation, but the applicants contended that the regulation was inconsistent with other Community principles, and should be enjoined.

131. The Court held that such relief could be granted only if the national court entertains "serious doubts as to the validity of the Community measure," and itself refers that question to the Court of Justice if it has not been so referred; if "there is urgency and a threat of serious and irreparable damage to the applicant"; and if "the national court takes due account of the Community's interests," including requiring the applicant to post security if necessary. Joined Cases C-143/88 \& C-92/89, Zuckerfabrik Süderdithmarschen AG v. Hauptzollamt Itzehoe, 1991 E.C.R. I-415, II 33 (1991); see id. IUI 14-32.

132. The Court expressly stated that the "interim legal protection which Community law ensures for individuals before national courts must remain the same, irrespective of whether they contest the compatibility of national legal provisions with Community law [as in $\mathrm{Fac}$ tortame] or the validity of secondary Community law [as in Zuckerfabrik], in view of the fact that the dispute in both cases is based on Community law itself." Id. II 20; see also Case C68/95, T. Port GmbH \& Co. KG v. Bundesanstalt für Landwirtschaft und Ernährung, 1996 E.C.R. I-6065, 6103, [1997] 1 C.M.L.R. 1, 28 (1996) (treating Factortame and Zuckerfabrik criteria as identical); Case C-465/93, Atlanta Fruchthandelsgesellschaft mbH v. Bundesanstalt für Ernährung und Forstwirtschaft, 1995 E.C.R. I-3761, II 24, [1996] 1 C.M.L.R. 575, II 24 (1995).

133. Perhaps the Court merely meant that if interim relief would be available under Factortame, it must necessarily be available under Zuckerfabrik, but not the converse. Certainly some of the Zuckerfabrik conditions apply rather poorly to a Factortame-type case. For example, the "serious doubts" condition was premised on the notion that only the Court has the authority to hold a Community regulation invalid, and that the power of national courts temporarily to do so must be sharply restricted. Zuckerfabrik, 1991 E.C.R. I-415, II 23. That reasoning is inapplicable to cases solely evaluating the compatibility of national law with Community law. See Papadias, supra note 71, at 184. Similarly, the Court's insistence that the conditions for interim relief be uniform was predicated on the need to maintain the uniform application of the (suspect) Community regulation, a concern that seems less persuasive for provisions lacking direct applicability, such as directives. See Zuckerfabrik, 1991 E.C.R. I-415, III 25-26; $C f$. Oliver, supra note 51, 18-19 (opining that interim relief under Factortame is likely limited to directly effective provisions).

134. See Zuckerfabrik, 1991 E.C.R. I-415, III 16-17, (1991).

135. Both Factortame and Zuckerfabrik have since been cited in support of the Court of First Instance's jurisdiction to grant an interim award of damages in Article 288 (ex art. 215) proceedings, provoking the question of whether similar relief must be made available by national courts adjudicating questions of Community law. See Order of the President of the Court of Justice, Case C-393/96 P(R), Antonissen v. Council and Commission, 1997 E.C.R. I-441, 445 (1997); see also Case T-179/96 R, Antonissen v. Council and Commission 1997 E.C.R. II-425 (Ct. First Instance, 1997) (declining, under circumstances of case, to order such relief). Given the Court's mingling of its case law, it is highly likely that it would be favorably inclined. See Oliver, supra note 51, at 58-59. 


\section{c. State Liability in Damages}

In developing the relationship between Community law and mtional law, the Court focused on developing a comprehensive system of remedies for violations of Community law. Member State "non-contractual," or tort, liability was generally regarded as an important part of the puzzle, ${ }^{136}$ but the Court stopped short of holding squarely that Community law guaranteed such a remedy. ${ }^{137}$ Instead, it indicated that a revision to the Treaty-which it favored-would be necessary. ${ }^{138}$

State liability indeed seemed like a stretch. Given the widely varying conditions among Member States, it was hard for the Court to claim that state liability was a general principle common to Member States' national laws. ${ }^{139}$ The same conditions suggested

136. See Gerhard Bebr, Court of Justice: Judicial Protection and the Rule of Law, in Institutional Dynamics of European Integration, supra note 12, at 303, 327 ("A truly effective protection of Community rights requires that damages resulting from their breach be sanctioned by appropriate compensation."); Deirdre Curtin, Directives: The Effectiveness of Judicial Protection of Individual Rights, 27 Common Mkt. L. Rev. 709, 734 (1990).

137. Case 60/75, Russo v. AIMA, 1976 E.C.R. 45, 57 (if an individual "has suffered damage as a result of the intervention of a Member State in violation of Community law it will be for the State, as regards the injured party, to take the consequences upon itself in the context of the provisions of national law relating to the liability of the State."); see Anthony Arnull, Rights and Remedies: Restraint or Activism?, in Remedies for Breach of EC Law, 15, 22 (Julian Lonbay \& Andrea Biondi eds., 1997) (arguing that Francovich clariaed Russo as to Community law foundation for reparation, but stressed continuity with Russo by making judgment retroactive); Ami Barav, Damages in the Domestic Courts for Breach of Community Law by National Public Authorities, in Non-Contractual Liability of the European Communities, 149, 156 (Henry G. Schermers et al. eds., 1988) (noting ambiguity in Russo as to Community law right to damages); Carmen Plaza Martin, Furthering the Effectiveness of EC Directives and the Judicial Protection of Individual Rights Thereunder, 43 Int'l \& Comp. L.Q. 26, 39 (1994).

138. See Court of Justice, Suggestions of the Court of Justice on European Union, 2 Bull. Eur. Communities, Supp. 9/75, 18. Other language versions of the Court's proposal apparently make clear that the Court contemplated that a damages remedy be made available. See Prechal, supra note 43, at $306 \&$ n.1. The Member States were in fact considering a proposed revision to the Treaty that would have required them to adopt national non-contractual liability schemes at the time Francovich was decided, but the proposal was not among those adopted at the Maastricht meeting the following month. See Lenaerts, supra note 37, at 103. Unsurprisingly, some Member States later argued, unsuccessfully, that this rejection suggested that the Community's political organs did not intend to establish a general system of state liability for Community law infringements. See Brasserie du Pêcheur, 1996 E.C.R. I1029, đ[24, [1996] 1 C.M.L.R. 889, II 24 (1996).

139. See Hedley Lomas, 1996 E.C.R. I-2553, II 98, [1996] 2 C.M.L.R. 391, II98 (1996) (noting that laws of Italy, Germany, Belgium, Ireland, Luxembourg, and the United Kingdom appear not to impose liability on state for legislative acts); Opinion of Advocate General Léger, Brasserie du Pêcheur, 1996 E.C.R. I-1029, II 36, [1996] 1 C.M.L.R. 889, II36 (1996) (acknowledging "widespread" idea that state was not liable for legislative acts or omissions); see also David A.O. Edward \& Robert C. Lane, European Community Law: An Introduction 59 (2d ed. 1995) (noting "wide disparity in national law of public tort liability," with civil law systems generally providing for easier access to damages); Steiner, supra note 102, at 52 (concluding that in majority of cases, Member States provide for public liability "only in respect of administrative or executive acts"); Walter van Gerven, Taking Article 215(2) EC Seriously, in New Directions in European Public Law, supra note 25, at 36 \& n.4. Later 
divergent views as to whether the lack of recourse to sovereign liability-particularly for legislative acts-made effective enforcement of rights virtually impossible, with the Community law remedies of restitution and interim relief making the case still harder. Additionally, the absence in many member States of similar remedies for sovereign breaches of national law insulated them against charges of discrimination. ${ }^{140}$

Nevertheless, the Court took that step in Francovich. Employees injured as a result of Italy's failure to implement a directive guaranteeing wages in the event of a company's insolvency sued the government for relief. Asked by an Italian court whether the directive had direct effect, the Court of Justice took a relatively parsimonious view. While the directive clearly identi ${ }^{a}$ ed the persons entitled to the wage guarantee and the content of that guarantee, it was thought too inde anite as to the guarantor, since Member States could choose between requiring employers to ${ }^{a}$ nance the guarantee institution or shouldering that burden themselves. ${ }^{141}$

Having dismissed the idea that Italy was liable as a debtor, the Court turned to the theory that the employees could sue the state as

Community members did not markedly improve the consensus. See Torbjörn Andersson, Remedies for Breach of EC Law Before Swedish Courts, in Remedies for Breach of EC Law supra note 137, at 211-13 (noting discrepancy between Francovich and existing Swedish public liability law). See generally Governmental Liability: A Comparative Study (John Bell \& Anthony W. Bradley eds., 1991).

140. For that reason, the English Court of Appeal's conclusion that a damages remedy would lie against the government only where the claimant could substantiate an ordinary civil action in damages for misfeasance seemed entirely defensible prior to Francovich. Bourgoin S.A. and others v. Ministry of Agriculture, Fisheries and Food (English Court of Appeal), [1986] 1 C.M.L.R. 267, 309 (1985); see also Jane Convery, State Liability in the United Kingdom After Brasserie du Pêcheur, 34 Common Mkt. L. Rev. 603, 616-17 (1997).

141. Cases C-6/90 \& C-9/90, Francovich v. Italy, 1991 E.C.R. I-5357, III 14-27, [1993] 2 C.M.L.R. 66, IIII 14-27 (1991); see Deirdre Curtin, State Liability Under Community Law: A New Remedy for Private Parties, 21 Indus. L.J. 74, 77 (1992) (describing Francovich as establishing "the outer parameters" of the unconditionality requirement). The Court resisted a passable argument that since Italy had breached its duty to implement, it lost its right to elect employer a nancing — estopped from disavowing a nancial responsibility. See Francovich, 1991 E.C.R. at IIII 24-25, [1993] 2 C.M.L.R. at IIII 24-25. One may distinguish between deeming that the Member State must suffer application of a directive after its discretionary period for implementation has entirely lapsed and arguing that the same conduct abridges discretion vested in the Member State by the directive. However, the Court's resistance was odd, given its acceptance of an analogous argument as to whether the guarantee's content would satisfy direct effect. According to the Court, the mere fact that Member States were empowered to set ceilings on payment did not give rise to uncertainty, since those states failing to implment the directive could not be permitted to "defeat the rights which the directive creates for the beneat of individuals" by relying on a prerogative they might have exercised had they followed the proper course. Francovich, 1991 E.C.R. at II 21, [1993] 2 C.M.L.R. at II 21. The Court also noted that under the directive, Member State discretion existed only as to the method of anancing, while the payment obligation lay in all cases with the guarantee instit tr tions. Id. at 5412 If 25; see also Francovich, 1991 E.C.R. at 5378. Given that Member States were to create and arrange for the anancing of such institutions in one fell swoop, the Court's distinction seems unconvincing. But see Curtin, supra, at 76 (criticizing Francovich's analysis of guarantee's content). 
tortfeasor, which it endorsed in a summary fashion. ${ }^{142}$ The Court's basic argument was unexceptionable: without such liability, the directive's putative bene ${ }^{\mathrm{a}}$ ciaries would be worse off. The legal basis, though, was somewhat harder to ascertain. The Court cited case law as to the importance of guaranteeing the full effectiveness of drectly effective and directly applicable rights ${ }^{143}$ - which were not at stake in Francovich - then noted that the absence of direct effect merely heightened the need for Community intervention. ${ }^{144}$ To the Court, it was considered "inherent in the system of the Treaty" that this abscess be cured by holding Member States responsible. ${ }^{145}$ More specia cally, the Court cited Member States' Community law obligations under Article 10 (ex art. 5), ${ }^{146}$ which were said to entail the "obligation to nullify the unlawful consequences of a breach of Community law"147 and the duty "to make good loss and damage

142. See Ami Barav, State Liability in Damages for Breach of Community Law in the National Courts, 16 Y.B. Eur. L. 87, 90 (1996).

143. See Francovich, 1991 E.C.R. at II 32, [1993] 2 C.M.L.R. at 9 32 (citing Case 106/77, Amministrazione delle Finanze dello Stato v. Simmenthal SPA, 1978 E.C.R. 629, and Case C-213/89, The Queen v. Secretary of State for Transport ex parte Factortame Ltd, 1990 E.C.R. I-2433, [1990] 3 C.M.L.R. 1 (1990)).

144. Francovich, 1991 E.C.R. at I[ 34, [1993] 2 C.M.L.R. at If 34.

145. Id. at II 35. The Court cited Van Gend en Loos and Costa v. ENEL to describe the Treaty as a constitution that reached through national governments to bestow obligations on individuals and, reciprocally, rights. Id. at II 31 (citing Case 26/62, Van Gend en Loos, 1963 E.C.R. 1, [1963] C.M.L.R. 105 (1963), and Case 6/64, Costa v. ENEL, 1964 E.C.R. 585, [1964] C.M.L.R. 425 (1964)); see supra note 53 (discussing Van Gend en Loos). That nostrum was singularly inapposite to an unimplemented directive, which was at issue in Francovich. In fact, directives do not impose obligations on individuals, nor do unimplemented directives establish any rights. See Elies Steyger, Europe and its Members: A Constitutional Approach 4 (1995).

Likewise, any individual rights conferred by directives cannot, contrary to Francovich, arise "by virtue of obligations which the Treaty imposes in a clearly de ned manner ... on individuals." That is the thrust of the Court's case law denying horizontal direct effect to unimplemented directives. See Coppel, supra note 23, at 866-67, 870 (emphasizing this implication in Marshall, and noting tension with Francovich). In casting about for the obligor, the Court ignored the possibility that the Treaty's reciprocity might make private parties responsible. Instead, it held that the government must be held responsible despite uncertainty as to the party against whom the right was to be asserted. Direct effect would not only require identiacation of such a party in order to satisfy the requirement of being suf ${ }^{a}$ ciently precise and unconditional, but for directives, the Member State would have to be the party identiaed.

146. Article 10 provides that:

Member States shall take all appropriate measures, whether general or particular, to ensure ful ${ }^{\mathrm{a}} \mathrm{lm}$ ent of the obligations arising out of this Treaty or resulting from action taken by the institutions of the Community. They shall facilitate the achievement of the Community's tasks.

They shall abstain from any measure which could jeopardise the attainment of the objectives of this Treaty.

EC Treaty art. 10 (ex art. 5).

147. Francovich, 1991 E.C.R. at II 36, [1993] 2 C.M.L.R. at If 36 (citing Humblet v. Belgium, 1960 E.C.R. 559). Humblet, a case involving the European Coal and Steel Community, is a rather dif ${ }^{\mathrm{a}}$ cult decision to shoehorn into a constitutional principle. Though it concerned a right that certainly would be considered directly effective and directly applicable, it preceded much of the Court's elaboration of those doctrines; more to the point, perhaps, it was entirely 
caused to individuals by breaches of Community law for which [Member States] can be held responsible."148

From these premises, Francovich forged a right to reparation "founded directly on Community law."149 It also stipulated, again without explanation, two conditions for invoking it: (1) the directive in question must have attempted to confer identiable rights on individuals, and (2) there had to be a causal link between the Member State's breach of its obligation to implement the directive and the individual's damage. ${ }^{150}$ Once these two conditions were fullalled, national rules could vary, subject to the now secondary nondiscrimination and effectiveness principles. ${ }^{151}$

Francovich was almost universally accepted within the academy, which took suspicious pains to emphasize how the decision was perfectly predictable and precedent bound. ${ }^{152}$ But it was certainly legally distinctive. As Judge Lenaerts noted, Francovich "marked

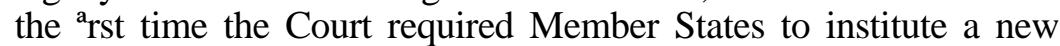
judicial action, which might have been fully unknown in their mtional legal traditions, in order to provide an effective judicial remedy for the infringement of Community law on the part of the mtional political process." 153 It also "sent shock waves through European capitals" as national governments were forced to confront a principle of uncertain, but potentially enormous, ${ }^{\text {anancial implic a- }}$ tions. ${ }^{154}$ Both supporters and critics were concerned about a back-

dicta, as the Court expressly held it lacked the power to entertain the plaintiff's claim. Humblet, 1960 E.C.R. at 569.

148. Francovich 1991 E.C.R. at II 37, [1993] 2 C.M.L.R. at II 37.

149. Id. at 9141.

150. Id. at $\mathbb{\Phi} 40$

151. Id. at TITI 41-43.

152. See, e.g., Opinion of Advocate General Tesauro, Brasserie du Pêcheur, 1996 E.C.R. I-1029, I[ 32, [1996] 1 C.M.L.R. 889, I[ 32 (1996) ("[F]ar from being a moment of eccentricity in the case-law of the Court, Francovich was completely consistent with and a logic extension of a value which has been upheld on several occasions without question in Luxembourg."). See also Arnull, supra note 137, at 20 ("What is surprising aboutFrancovich is that the principle of State liability was not unequivocally established much sooner."); Barav, supra note 142, at 89-91; Nicholas Emiliou, State Liability Under Community Law: Shedding More Light on the Francovich Principle?, 21 Eur. L. Rev. 399 (1996); Josephine Steiner, From Direct Effects to Francovich: Shifting Means of Enforcement of Community Law, 18 Eur. L. Rev. 3, 9 (1993) ("The decision in Francovich is undoubtedly consistent with, and a natural and logical extension of, the Court's case law."); Waelbroeck, supra note 12, at 468 (" $[\mathrm{O}]$ ne must inevitably wonder why it took more than thirty years for the Court to come to a conclusion which seems to be so inherent to the whole legal system of the Community, and in particular to the system of direct applicability and primacy of Community law."); $i d$. at 471 (demonstrating, "if need be, that the principles of the Francovich judgment-although never clearly expressed by the Court-were in fact inherent to Community law"). But see O'Keefe, Judicial Protection, supra note 71, at 908-09 (describing Francovich as innovative); Snyder, supra note 31, at 44 (same).

153. See Lenaerts, supra note 12, at 146; see O'Keefe,Judicial Protection, supra note 71, at $908-09$.

154. See Geoffrey Garrett, R. Daniel Kelemen, \& Heiner Schulz, The European Court of 
lash. ${ }^{155}$ Indeed, the abreaction by some powerful Member States to the notion of a Community standard for state liability, ${ }^{156}$ followed by case law that appeared to raise the bar for liability actions, ${ }^{157}$ led some to suppose that the Court was pressured by Member States into reducing their ${ }^{a}$ nancial exposure. ${ }^{158}$

If so, Member States used little of their in ${ }^{\circ}$ uence to secure greater leeway for national variation. First, the Court determined that the principle of state liability "holds good for any case in which a Member State breaches Community law," 159 including breaches by administrative of ${ }^{a}$ cials and Treaty violations. Though the absence of direct effect was deemed to make state liability "particularly indispensable" in Francovich, ${ }^{160}$ the Court thereafter dispensed with any notion of symmetry. Instead, the full effectiveness of Community law was "all the more" impaired when the right infringed had been created by direct effect, since then "the right to reparation is the necessary corollary of the direct effect of the Community provision

Justice, National Governments, and Legal Integration in the European Union, 52 Int'l Org. 149, 170 (1998).

155. See Harlow, supra note 21 , at 214.

156. See, e.g., Marc Fierstra, The Signi cance of the Francovich Jurisprudence for the National Courts, in European Ambitions of the National Judiciary 111 (Rosa H.M. Jansen et al. eds., 1997) (describing "great lengths" to which national governments were going to in order to restrict a nancial effects of Francovich). In Francovich itself, the four governments submiting observations-Italy, naturally enough, together with Germany, the Netherlands, and the United Kingdom - all maintained that the question of whether liability should attach for a failure to legislate should be entrusted solely to national law. Germany, the Netherlands, and Ireland later argued in Brasserie du Pêcheur against any extension of Francovich. See Joined Cases C-46/93 \& C-48/93, Brasserie du Pêcheur, 1996 E.C.R. I-1029, [1996] 1 C.M.L.R. 889 (1996). Following Brasserie du Pêcheur, the United Kingdom submitted a memorandum to the IGC asking the Treaty be amended to re ${ }^{\circ}$ ect the state liability principles articulated by the Court. But it also urged, among other things, (1) a limitation on damages payable by Member States (to not more than three years prior to the initiation of suit), (2) express recognition of the Court's authority to limit the retrospective effect of its judgments, including in cases of "serious "nancial consequences for natural or legal persons or the public anances of any Member State," and (3) introduction of an appeal procedure in the Court of Justice. See U.K. Memorandum, supra note 22.

Local reaction was less balanced. Aware of potential liability on the order of 30 million pounds, the U.K. 'sheries minister called the Court's decision "crazy" and called for Treaty changes to alter the common "sheries policy, while Tory Members of Parliament tabled a motion that would have the United Kingdom withdraw altogether from the policy. See Fin. Times, Mar. 9, 1996, at 2; see also Community Law: EU Court Upholds Individuals' Rights Against Member States, Eur. Rep., Mar. 9, 1996. Another M.P. reacted to the judgment by introducing a bill that would enable the Council to set aside Court of Justice judgments, but that bill was defeated at ${ }^{a}$ rst reading. See Robert Lane, The Fisherman's Tale: National Liability for Breaches of Community Law, 1 Edinburgh L. Rev. 91, 91 n.3 (1996).

157. See infra text accompanying notes 163-167.

158. See Garrett, Kelemen \& Schulz, supra note 154, at 168-74; cf. Lord Slynn of Hadley, Foreword, in Remedies for Breach of EC Law, supra note 137, at viii (inquiring "[i]s the current atmosphere browbeating, or inducing, the Court to be less creative-should it?").

159. See Case C-392/93, The Queen v. H.M. Treasury, ex parte British Telecommunications, 1996 E.C.R. I-1631 I[ 38, [1996] 2 C.M.L.R. 217, II 38 (1996).

160. Cases C-6/90 \& C-9/90, Francovich v. Italy, 1991 E.C.R. I-5357, II 34, [1993] 2 C.M.L.R. 66, II 34 (1991). 
whose breach caused the damage sustained." 161 Either direct effect or the lack thereof, it appeared, might lead to liability, and the Court made that plainer by emphasizing the indispensability of liability to securing individual rights. ${ }^{162}$

Second, the Court subsequently drew on its relatively strict test for the liability of Community institutions for legislative acts under Article 288 (ex art. 215) of Community institutions - which added the requirement that the causal link between state breach and the injury be "direct," and that the breach be "suf ciently serious."163 While this tended to diminish the potential liability of Member States, ${ }^{164}$ it also entrenched a Community law standard designed with little regard to differences among Member States and their courts. ${ }^{165}$ With respect to the most discretionary component, the question of whether a Member State breach was "sufaciently serious," the Court ostensibly con ${ }^{\text {a }}$ ed itself to indicating factors that national courts "may" take into account, ${ }^{166}$ but held that certain conditions were automatically sufaciently serious-including a Member State not taking the necessary steps to implement a directive. ${ }^{167}$

161. See Brasserie du Pêcheur, 1996 E.C.R. I-1029, II 22, [1996] 1 C.M.L.R. 889, II 22 (1996).

162. See infra text accompanying notes 193-195.

163. See Brasserie du Pêcheur, 1996 E.C.R. I-1029, III 37-74 [1996] 1 C.M.L.R. 889, IIII 37-74 (1996) (applying Article 215 standard for breaches of Community law by national legislatures); see Cases C-178, 179, 188-190/94, Dillenkofer v. Federal Republic of Germany, 1996 E.C.R. I-4845, TII 21-23, [1996] 3 C.M.L.R. 469, TITI21-23 (1996) (reviewing and reconciling case law). But see Francovich, 1991 E.C.R. I-5357 at II 40, [1993] 2 C.M.L.R. 66 at II 40.

164. See Hartley, supra note 6, at 228 (explaining that the "most remarkable feature [of the principles governing Community liability] is that it is extremely dif ${ }^{a}$ cult in practice for an applicant ever to obtain damages," and citing estimate that only eight awards have ever been made against the Community); Prechal, supra note 43, at 319 (same); Tamara K. Hervey \& Philip Rostanti, After Francovich: State Liability and British Employment Law, 25 Indus. L.J. 259, 261 (1996) (same); see generally The Action for Damages in Community Law (Ton Heukels \& Alison McDonnell eds., 1997). Professor Hartley also notes, however, that the Court's application of this standard against Member States has appeared to be more generous. Hartley, supra note 6, at 228.

165. For a forceful argument to the effect that too little of Article 288 (ex art. 215) was incorporated, see van Gerven, supra note 139, at 35.

166. Joined Cases C-46/93 \& C-48/93, Brasserie du Pêcheur, 1996 E.C.R. I-1029, II56, [1996] 1 C.M.L.R. 889, II 56 (1996) (In resolving whether breach of Community law by Community or Member State institutions is "suf"ciently serious," "[t]he factors which the competent court may take into consideration include the clarity and precision of the rule breached, the measure of discretion left by that rule to the national or Community authorities, whether the infringement and the damage caused was intentional or involuntary, whether any error of law was excusable or inexcusable, the fact that the position taken by a Community institution may have contributed toward the omission, and the adoption or retention of mtional measures or practices contrary to Community law.").

167. See Cases C-178-79 \& C-188-90, 188 to 190/94, Dillenkofer v. Germany, 1996 E.C.R. I-4845, ФII 24-27, [1996] 3 C.M.L.R. 469, IITI 24-27 (1996). 
The Court maintained that national liability laws would continue to govern residual issues of reparation, ${ }^{168}$ but here too the sphere of national discretion was considerably reduced. Establishing a widely applicable and subtle principle of compensation proved a fertile ground for judicial supervision. Thus, in Brasserie du Pêcheur, the Court observed that a German standing doctrine that made reparation turn on whether the applicant was an intended bene $e^{\mathrm{a}}$ ciary of the obligation in question, and the English requirement of proof of misfeasance in public of ${ }^{a} c e$, would each make reparation impossible in practice or excessively dif ${ }^{a}$ cult to achieve. ${ }^{169}$ The Court has since volunteered its views on more mundane matters, such as the necessity of affording compensation for lost pro ${ }^{\mathrm{a} t s},{ }^{170}$ consequential damages, ${ }^{171}$ statutory interest,,${ }^{172}$ and exemplary or punitive damages. ${ }^{173}$

Finally, although national courts were nominally entrusted with determining whether the Community law conditions for liability were ful' ${ }^{\mathrm{a} l l e d},{ }^{174}$ the Court repeatedly pretermitted the inquiry. Beginning with Francovich, ${ }^{175}$ the Court occasionally decided whether state liability could be established, notwithstanding the potential fact-dependence of the evaluation. ${ }^{176}$ The Court more frequently

168. See, e.g., Francovich, 1991 E.C.R. at II 42, [1993] 2 C.M.L.R. at II 42.

169. See Dillenkofer, 1996 E.C.R. at TIII 68-73.

170. See Joined Cases C-46/93 \& C-48/93, Brasserie du Pêcheur, 1996 E.C.R. I-1029, IIII 86-87, [1996] 1 C.M.L.R. 889, TIII 86-87 (1996) (German practice potentially allowing total exclusion from damages of lost protts in trading cases contrary to Community law).

171. See Case C-373/95, Maso v. INPS, 1997 E.C.R. I-4051, II 41, [1997] 3 C.M.L.R. 1244, II 41 (1997) (noting if directive's beneaciaries establish "complementary loss sustained on account of the fact that they were unable to bene ${ }^{a} t$ at the appropriate time from the ${ }^{2}$ nancial advantages guaranteed by the Directive with the result that such loss must also be made good"); Case C-261/95, Palmisani v. INPS, 1997 E.C.R. I-4025, II 35, [1997] 3 C.M.L.R. 1356, II 35 (1997).

172. See Case C-66/95, Regina v. Secretary of State for Social Security, ex parte Sutton, 1997 E.C.R. I-2163, IIII 23-24, [1997] 2 C.M.L.R. 382, TIII 23-24 (1997) (distinguishing between damage awards, which require interest to afford complete relief, and retroactive awards of social security beneats wrongly withheld, which do not); $c f$. Case C-373/95, Maso, 1997 E.C.R. at II 41 (requiring damages approximating retroactive and proper application in full of directive); Case C-261/95, Palmisani, 1997 E.C.R. at 935.

173. In Brasserie du Pêcheur, the Court noted only that exemplary damages would be required under conditions no less favorable than for similar breaches of national law. See Joined Cases C-46/93 \& C-48/93, Brasserie du Pêcheur, 1996 E.C.R. I-1029, II 89, [1996] 1 C.M.L.R. 889, II 89 (1996).

174. Case C-392/93, The Queen v. H.M. Treasury, ex parte British Telecommunications, 1996 E.C.R. I-1631, II 41, [1996] 2 C.M.L.R. 217, II 41 (1996) ("[I]t is in principle for the national courts to verify whether the conditions governing State liability for a breach of Community law are fulalled.”); Brasserie du Pêcheur, 1996 E.C.R. I-1029, I[58, [1996] 1 C.M.L.R. 889, II 58 (1996); see generally European Court of Justice, Guidance on References by National Courts for Preliminary Rulings, [1997] 1 C.M.L.R. 78, 79 (1996) ("[T]he Court of Justice does not have jurisdiction to interpret national law or assess its validity. It is for the referring court or tribunal to apply the relevant rule of Community law in the cases before it.").

175. See Francovich, 1991 E.C.R. at TIII 44-45 (concluding that right to reparation existed).

176. See Chalmers, supra note 60 , at 194. Thus, for example, in Brinkmann Tabakfab- 
conveyed only vaguely subtler signals. Thus, in Brasserie $d u$ Pêcheur, just after emphasizing that national courts had "sole jurisdiction" to apply Community law, the Court noted that "it would be dif "cult" to regard one aspect of the German legislation at issue as "excusable error," quite in contrast to a second aspect as to which "signia cantly less conclusive" guidance had been available. ${ }^{177}$ The Court's disregard for the limits of its function on preliminary reference is scarcely novel, ${ }^{178}$ but arguably infringes on responsibility of national courts - not to mention the rights of Member States to defend their positions ${ }^{179}$ - in an area of the most acute sensitivity.

\section{Convergence in the Community}

The Francovich doctrine of state liability culminates an evolution in Community remedies that has profoundly affected the basic legal relations etched by the Court-in particular, as to the continued distinctiveness and vitality of the directive and its expression through direct effect. The doctrine also caps a period of encroachment into the discretion traditionally afforded national remedies, setting the stage for a uniformity, or homogeneity, of Member States' national laws long sought by some of the Court's most ar-

riken, the Court bypassed its ordinary threshold inquiry into whether the directive in question conferred rights on individuals - ordinarily the least fact-sensitive of the three inquiries - on the ground that it had suf ${ }^{a}$ cient information before it to resolve both the issues of suf ${ }^{a}$ ciently serious breach and causation. Case C-319/96, Brinkmann Tabakfabriken v. Skatteministeriet, [1998] 3 C.M.L.R. 673, II 26 (1998); see also Chalmers, supra note 60, at 193 (suggesting that only national courts are well-equipped to determine issue of causation); see also Hedley Lomas, 1996 E.C.R. I-2553 at TाI 27-30, [1996] 2 C.M.L.R. 391, III 27-30 (1996) (suggesting Community law in question conferred rights on individuals, and Member State breach was sufaciently serious, but national courts were to determine whether causal link existed); $c f$. Case C-127/95, Norbrook Laboratories v. Ministry of Agruculture, Fisheries, and Food, 1998 E.C.R. I-1531 at IIII 108-111, [1998] 3 C.M.L.R. at IIII 108-111 (holding directive conferred rights on individuals, but that question of direct causal link was for national court to evaluate, and failing to address presence of suf ${ }^{\mathrm{a}}$ ciently serious breach); Case C-140/97, Rechberger v. Republic of Austria, 1999 ECJ CELEX 1882, II 73 (Eur. Ct. Justice, June 15, 1999) (deferring to national court anding regarding existence of direct causal link).

177. Brasserie du Pêcheur, 1996 E.C.R. at TIII 58-59. As to the U.K. legislation also at issue, the Court noted anumber of speciac facts that the national court "might take into $x$ count," and stated that if a contested allegation should prove correct, "it should be regarded by the national court as constituting in itself a manifest and, therefore, suf ${ }^{a}$ ciently serious breach of Community law."

178. See Hartley, supra note 6, at 299 (noting that while Court of Justice has power to interpret Community law, but not to apply it, "[t]he precise distinction between interpretation and application is ... very elastic and the European Court appears to make use of this elasticity for its own purposes"); see also Federico Mancini \& David Keeling, Democracy and the European Court of Justice, 57 Mod. L. Rev. 175, 184-85 (1994); Mancini, supra note 4, at 606 .

179. See Denis F. Waelbroeck, Treaty Violations and Liability of Member States: The Effect of the Francovich Case Law, in The Action for Damages in Community Law 311, 323 24 (Ton Huels \& Alison McDonnell eds., 1997). 
dent supporters. Both developments are vital to understanding the challenge that state liability poses for subsidia rity.

\section{Convergence Within Community Law}

Although directives were originally intended to confer discretion on Member States, their distinctiveness diminished considerably with the attachment of direct effect. ${ }^{180}$ The Community also increasingly used the directive to provide a detailed template for mtional legislation that left little room for meaningful variation. ${ }^{181}$ As explained in Section III, one reason for this evolution was the absence of effective enforcement mechanisms. Because the Commission lacked the legal authority and esources to detect and address nonimplementation, the only effective way to improve implementation was to increase the level of detail in directives and decrease the level of discretion left to Member States. The Court's arst generation of remedies jurisprudence only exacerbated the trend. Extending direct effect to directives encouraged legislators concerned with enforceability to make sure that the directives were suf a ciently speci $^{\mathrm{a}} \mathrm{c}$ and discretion-narrowing to meet its test.

180. Indirect effect contributed to this drift. Although it might originally have been rationalized as an attempt to divine the intent of national legislators adopting a directive, see de Búrca, supra note 21, at 224-25 (discussing English law); see also Opinion of Advocate General Mischo, Case 80/86, Of ${ }^{a}$ cier van Justitie v. Kolpinghuis Nijmegen, 1987 E.C.R. 3969, 3978, [1989] 2 C.M.L.R. 18, 23 (1987) (indicating that indirect effect is inapplicable to national law existing prior to a directive's adoption); Opinion of Advocate General Slynn, Case 152/84, Marshall v. Southampton and South West Hampshire Area Health Authority, 1986 E.C.R. 723, 731-33, [1986] 1 C.M.L.R. 688, 709-11 (1986) [hereinafter Marshall I], the Court later applied the principle to national law not aimed at implementation, including that which could have been enacted before the directive in question. See Case C-106/89, Marleasing SA v. La Comercial Internacional de Alimentación SA, 1990 E.C.R. 4135, [1992] 1 C.M.L.R. 305 (1990). Recent case law takes this principle further by holding that national courts are obliged to act in accord with indirect effect from the time the directive is initially notia ed, even though the Member State will as yet be under no obligation to implement the directive. See Case 129/96, Inter-Environnement Wallonie ASBL v. Région Wallonne, 1997 E.C.R. I-7411, গII 45-50, [1998] 1 C.M.L.R. 1057, III 45-50 (1997) (holding that Member States assume a duty to act consistently with a directive as of time it is initially notiaed); see also Kolpinghuis, 1987 E.C.R. at I[ 15, [1989] C.M.L.R. 18 at II 15 (1989) ("[W]hether or not the period prescribed for implementation has expired" may be immaterial for purposes of indirect effect); Prechal, supra note 43, at 23 (citing authorities).

181. See Francesco Caportiti, Legal Problems of Directives, Regulations and their Implementation, in 1 Making European Policies Work: The Implementation of Community Legislation in Member States: Comparative Syntheses 151, 156-57 (Heinrich Siedentopf \& Jacques Ziller eds., 1988) ("[T] extensive design and description of the result of each drective has led to reducing to zero Member States' freedom in the area of implementation (except with regard to form, which has to remain a secondary element). When all is said and done, the degree of centralization attained by directive appears to have disregarded one of the sound reasons for their separation from the system of regulations."); see also Hartley, supra note 6, at 215 (observing that "the Community institutions long ago adopted the habit of enacting directives with provisions every bit as detailed and precise as those to be found in a regulation"); Jacques Ziller, Conclusions and Issues of the IVth Erenstein Colloquium, in Making European Policies Work, supra at 133. 
The new damages jurisprudence further eroded the distinctive character of directives, in part by crafting a test for state liability that applies irrespective of the source of a Community law right. ${ }^{182}$ Francovich also spurred further evolution in the doctrine of direct effect, a doctrine that always seemed somewhat vestigial. ${ }^{183}$ The Court gradually relaxed the threshold for "nding direct effect. ${ }^{184}$ Nevertheless, there were limits, such as the bar against "horizontal" direct effect for directives. While an ever-widening body of defendants were found to constitute state actors subject to "vertical" drect effect, ${ }^{185}$ this undermined the estoppel theory of direct effect by making liable parties that could not be blamed for nonimplementation. ${ }^{186}$ It also highlighted the unequal treatment of those wronged by the narrowing class of private parties. ${ }^{187}$ The re-

182. See Cases C-178, 179, \& C-188 to 190/94, Dillenkofer v. Germany, 1996 E.C.R. I4845, III 21-23, [1996] 3 C.M.L.R. 469, IIII 21-23 (1996). For potential plaintiffs, the differences among the types of Community law are of diminishing importance, at least as of when the period for transposing a directive has elapsed. Given the Court's recent holding that drectives may be legally effective in some regards as of the time they are notia ${ }^{\mathrm{a}} \mathrm{ed}$ to Member States, see Case 19/96, Inter-Environnement Wallonie ASBL v. Région Wallonne, 1997 E.C.R. I-7411, [1998] 1 C.M.L.R. 1057, II 41 (1997) ("a directive has legal effect with respect to the Member State to which it is addressed from the moment of its notiacation"); id. at IIII 41-45 (describing obligations of Member States to avoid compromising directive's result prior to transposition), even that distinction may be fading.

183. Judge Pescatore, for example, colorfully declared that direct effect was an "infant disease of Community law," to be cured once it became feasible to recognize direct effect as the goal of all Community law. Pierre Pescatore, The Doctrine of "Direct Effect": An Infant Disease of Community Law, 8 Eur. L. Rev. 155, 155 (1983).

184. See Tillotson, supra note 51, at 168-69 (quoting van Gerven); Case C-271/91, Marshall II, 1993 E.C.R. I-4367, [1993] 3 C.M.L.R. 293 (1993).

185. See Case 188/89, Foster v. British Gas, 1990 E.C.R. I-3313, I 18, [1990] 2 C.M.L.R. 833, II 18 (1990) (directly effective provisions can be relied upon against entities "subject to the authority or control of the State or [having] special powers" those normally attending private parties); $i d$. at TIII 19-20 (citing broad range of examples); e.g., National Union of Teachers v. Governing Body of St. Mary's Church of England (Aided) Junior School, [1997] I.C.R. 334, [1997] 3 C.M.L.R. 630 (1997) (Ct. App., Civ. Div.). Illustrating the interplay between remedial doctrines, one commentator suggested that National Union of Teachers "revitalise[d]" vertical direct effect after a period in which the discovery of state liability meant that "the doctrine of direct effect, with all of its foibles and shortcomings, began to look like the ugly sister at the ball." Paul Spink, Direct Effect: The Boundaries of the State, 113 L.Q. Rev. 524 (1997).

186. See Prechal, supra note 43, at 301; Craig, supra note 42, at 523. A ready example was provided by Advocate General van Gerven's opinion in Foster, in which he struggled to reconcile the case law allowing vertical direct effect with the estoppel rationale. See Opinion of Advocate General van Gerven, Case 188/89, Foster v. British Gas, 1990 E.C.R. I-3313, [1990] 2 C.M.L.R. 833 (1990); see also Opinion of Advocate General Lenz, Case C-91/92, Faccini Dori v. Recreb, 1994 E.C.R. I-3325, If 55 \& n.43, [1995] 1 C.M.L.R. 665, If 55 \& n.43 (1995) (noting that, even for vertical direct effect, "direct responsibility for the infringement of the Treaty is not necessary, as witness the broad interpretation given by the Court's case law to the concept of the State.").

187. See Opinion of Advocate General Lenz, Case C-91/92, Faccini Dori v. Recreb, 1994 E.C.R. I-3325, II 515 [1995] 1 C.M.L.R. 665, II515 (1994); O'Keefe, Judicial Protection, supra note 71, at 904 (Lack of horizontal direct effect "left individuals in an absurd situation regarding access to legal remedies," varying relief based on identity of the defendant "even though the underlying problem might be the same in both cases."). 
sult was a rising chorus against the limitations on horizontal direct effect for directives. ${ }^{188}$

The Francovich doctrine relieves some pressure on the doctrine of direct effect by providing a remedy where direct effect would not, particularly in the case of directives. ${ }^{189}$ Individuals unable to rely directly on a non-transposed directive because the relevant provisions are insuf ${ }^{a}$ ciently precise and unconditional may have recourse to state liability. ${ }^{190}$ State liability also addresses the lack of horizontal direct effect, since it is now possible to sue the state for failing to prevent harms perpetrated by private parties. ${ }^{191}$ Put crudely, state liability meant that there was no compelling reason for the Court to test direct effect's seams. ${ }^{192}$

At the same time, the Court's rationale seriously undermined the traditional bases for limiting directives and direct effect. The Court left unmentioned the instrumental case for a principle of state 1ability-namely, the need to incent Member States to comply with their Community law obligations to a greater degree than permitted

188. The Court was particularly vulnerable to complaints that it was choosing a poor occasion to remain true to the literal restraints of then Article 189. See, e.g., Stephen Weatherill, Law and Integration in the European Union 131-32 (1995) (characterizing the Court's textual analysis as "counter to the trend of thirty years of case law in this area"); Christine Boch $\&$ Robert Lane, European Community Law in National Courts: A Continuing Contradiction, 5 Leiden J. Int'l L. 171 (1992); Coppel, supra note 23, at 863-64 ("To base, at this stage, the argument against horizontal direct effect for directives on a narrow textual interpretation of Article 189 is certainly surprising and arguably disingenuous.").

189. See, e.g. , Ross, supra note 25 , at 60 (citing this as " $[\mathrm{t}]$ he clearest value of the remedy in Francovich"). In this sense, it is the antithesis to the decision just two years before in Case 380/87, Enichem Base v. Comune di Cinisello Balsamo, 1989 E.C.R. 2491, [1991] 1 C.M.L.R. 313 (1991), where the Court had deemed the issue of state liability irrelevant given its conclusion that the directive in question lacked direct effect.

The converse may also be true: where state liability is dif ${ }^{a}$ cult to establish, perhaps because the breach in question is insuf aciently "serious," direct effect may be available. See Steiner, supra note 152, at 20. For a discussion of the relationship between state liability and other Community and national law remedies, see Piet Eeckhout, Liability of Member States in Damages and the Community System of Remedies, in New Directions In European Public Law, supra note 25, at 63.

190. See Joined Cases C-46/93 \& C-48/93, Brasserie du Pêcheur, 1996 E.C.R. I-1029, IIII 20-21, [1996] 1 C.M.L.R. 889, IIII 20-21 (1996); see Opinion of Advocate General Léger, Hedley Lomas, 1996 E.C.R. I-2553, II 82, [1996] 2 C.M.L.R. 391, II 82 (1996) ("It is therefore clear that the Francovich judgment alls a lacuna in the protection afforded to individuals who wish to rely on a directive which has not been tran sposed.").

191. See Deirdre Curtin, The Decentralised Enforcement of Community Law Rights: Judicial Snakes and Ladders, in Constitutional Adjudication in European Community and National Law 33 (Deirdre Curtin \& David O'Keeffe eds., 1992); see also Martin, supra note 137, at 33; Waelbroeck, supra note 12, at 474-75. The Court made this connection explicit when, in reaf ${ }^{\mathrm{a}}$ rming its rejection of horizontal direct effect in Faccini Dori, it reckoned that state liability provides a compelling reason-in addition to its episodic respect for the importance of maintaining the distinctive character of directives - why horizontal direct effect was no longer necessary. See Case C-91/92, Faccini Dori v. Recreb, 1994 E.C.R. I-3325, II 27, [1995] 1 C.M.L.R. 665, II 27 (1995); accord Case C-192/94, El Corte Inglés v. Blázquez Rivero, 1996 E.C.R. I-1281, II 22, [1996] 2 C.M.L.R. 507, II 22 (1996).

192. See Craig, supra note 42 , at 537. 
by direct effect. ${ }^{193}$ The goal of making Community law effective, instead, was described as a matter of securing its extension of rights to individuals by affording compensation; 194 the advantage over direct effect, likewise, was considered in terms of those individual interests. ${ }^{195}$ These differing notions of effectiveness are by no means mutually exclusive, and indeed overlap considerably in result. But in taking the tack it did, Francovich pushed the argument for effective judicial protection farther than any case had before, ${ }^{196}$ and, in so doing, wound up doing much more than simply alling in direct effect's gaps. For many, including a number of Advocates General, Francovich requires reconsidering of the rule against hor izontal direct effect for directives. ${ }^{197}$ If sustaining Community law rights requires a damages remedy, so the argument goes, the defen-

193. Commentators drawn to that argument thus could only speculate that it played a part in the Court's judgment. See, e.g., Smith, supra note 76, at 303; Steiner, supra note 152, at 9; Tridimas, Member State Liability in Damages for Breach of Community Law: An Assessment of the Case Law, in New Directions in European Public Law, supra note 25, at 13-14. For more direct invocations of deterrence values, see Opinion of Advocate General Tesauro, Cases C-6/90 \& C-9/90, Francovich v. Italy, 1991 E.C.R. I-5357, II92, [1993] 2 C.M.L.R. 66, II 92 (1993) (arguing that "the proposed approach has the great advantage of providing strong encouragement for Member States to implement directives within the prescribed periods"); Opinion of Advocate General Tesauro, Joined Cases C-46/93 \& C-48/93, Brasserie du Pêcheur, 1996 E.C.R. I-1029, I] 27, [1996] 1 C.M.L.R. 889, II 27 (1996); Opinion of Advocate General Léger, Case C-5/94, Hedley Lomas, 1996 E.C.R. I-2553, [1996] 2 C.M.L.R. 391 (1996).

194. See Cases C-6/90 \& C-9/90, Francovich v. Italy, 1991 E.C.R. I-5357, II 32, [1993] 2 C.M.L.R. 66, II 32 (1993) ("[N]ational courts whose task it is to apply the provisions of Community law in areas within their jurisdiction must ensure that those rules take full effect and must protect the rights which they confer on individuals.").

195. See, e.g., Brasserie du Pêcheur, 1996 E.C.R. at II 20, [1996] 1 C.M.L.R. at II 20 (describing direct effect as "only a minimum guarantee" insufacient to ensure "full and complete implementation of the Treaty"); $i d$. at TII 20-22 (stressing direct effect's inability to secure individual rights, rather than any more general frustration of Community law, and that even where direct effect was available, a right to reparation under Francovich existed as a matter of individual right).

196. Opinion of Advocate General Tesauro, Joined Cases C-46/93 \& C-48/93, Brasserie $d u$ Pêcheur, 1996 E.C.R. I-1029, I] 33, [1996] 1 C.M.L.R. 889, II 33 ("[I]t is the Francovich situation itself which represents possibly the furthest which the case law of the Court can go ... the Francovich judgment conferred a remedy (at least a anancial one) where the remedy provided for was that laid down in Article 169, which does not afford a direct protection for individuals"); id. at IIIT 27,34; Coppel, supra note 23, at 870-72; Caranta, supra note 21, at 707-10, 713; Tridimas, supra note 193, at 14.

197. See Opinion of Advocate General van Gerven, Case C-271/91, Marshall v. Southampton and South-West Hampshire Health Authority, 1993 E.C.R. I-4367, [1993] 3 C.M.L.R. 293 (1993) [hereinafter Marshall II]; Opinion of Advocate General Jacobs, Case C-316/93, Vaneetveld v. S.A. Le Foyer, 1994 E.C.R. I-763; Opinion of Advocate General Lenz, Case C-91/92, Faccini Dori v. Recreb, 1994 E.C.R. I-3325, IIII 43-73, [1995] 1 C.M.L.R. 665, গIII 43-73 (1995); see also Opinion of Advocate General van Gerven, Case C128/92, Banks v. British Coal Corporation, 1994 E.C.R. 1209; Coppel, supra note 23, at 870; Craig, supra note 42, at 537-38; Anthony Gardner, EU Member State Liability: A Cure for Euro-sclerosis?, 17 Eur. Comp. L. Rev. 275, 281-82 (1996); Alexander Winterstein, A Community Right in Damages for Breach of EC Competition Rules, 16 Eur. Comp. L. Rev. 49 (1995). 
dant's identity should not matter. ${ }^{198}$ Indeed, since state liability dispensed with some of the traditional requisites for direct effect, why not create private liability under similarly expansive conditions? ${ }^{199}$ The Court has not yet been persuaded, perhaps for reasons of expediency, ${ }^{200}$ but recent case law suggests its reluctance to maintain the traditional bulwark against enforcing Community law rights in purely private suits. ${ }^{201}$

The shift in the Court's emphasis from direct effect seemed signi $^{\text {acant }}$ and purposeful. ${ }^{202}$ Direct effect highlighted the dependence of the Community's federal system on Member State action and national law. State liability, in contrast, followed restitution and interim relief in proposing a Community law framework outside the framework of national law, and exceeded those other remedies in its autonomy from national law. ${ }^{203}$ Given the importance and ubiquity of such a remedy, the argument in favor of its complete uniformity, and the convergence of national law, seemed all the more forceful. ${ }^{204}$

\section{Convergence Among National Laws}

Although the Court nominally clings to the idea that national courts are free to determine the remedies for the infringement of EC

198. See Craig, supra note 42, at 520-24, 537-38.

199. See Chalmers, supra note 60, at 197; Clive Lewis \& Sarah Moore, Duties, Directives and Damages in European Community Law, 1993 Pub. L. 151, 164-65; Walter van Gerven, Non-Contractual Liability of Member States, Community Institutions and Individuals for Breaches of Community Law with a View to a Common Law for Europe, 1994 Maastricht J. Eur. \& Comp L. 1, 32 et seq.; Waelbroeck, supra note 12, at 475.

200. Hartley, for one, argues that while the principle of effectiveness may have logically entailed horizontal direct effect, the Court was presented with the rebellion by French and German Courts against the notion that directives could enjoy any kind of direct effect and may have struck a bargain sub silentio in which the principle of direct effect would be contained if those courts agreed to enforce its more limited version. See Hartley, supra note 6, at 218; Chalmers, supra note 60, at 189 (describing lack of horizontal effect as accommodating Member States). It is perhaps counter-intuitive, however, that Member States would have opposed extending Community liability to private parties, since that would invariably tend to diminish their own liability. See Eeckhout, supra note 189, at 65 (querying whether Member States should reconsider opposition to horizontal direct effect in light of state liability).

201. See Case C-180/95, Draehmpaehl v. Urania Immobilienservice OHG, 1997 E.C.R. I2195, [1997] 3 C.M.L.R. 1107 (1997) (evaluating application of Equal Treatment Directive in case against private employer); Case C-194/94, CIA Security Int'l SA v. Signalson, 1996 E.C.R. I-2201 (holding security alarm company excused from application of technical regulations, in light of breach by Belgian government of duty imposed by directive to notify and, potentially, delay implementation of such regulations); see also Ward, supra note 105, at 6572 (discussing Draehmpaehd; Jason Coppel, The Horizontal Effect of Directives, 26 Indus. L.J. 69 (1997) (discussing CIA Security).

202. See Steiner, supra note 152 , at 20 (suggesting that Court found the right at issue in Francovich not to be directly effective so that it could establish a principle of state liability not turning on that principle).

203. See Eeckhout, supra note 189, at 66.

204. See id. at 73 . 
law, subject to the limited restrictions of Rewe-Zentral${ }^{a}$ nanz/Comet, ${ }^{205}$ recent case law-led by Francovich - is eviscerating that standard. ${ }^{206}$ Effective judicial protection, and the new Community remedies, potentially restrict the discretion of Member States to limit recovery on any basis. ${ }^{207}$ Article 10 (ex art. 5), once regarded as acknowledging Member State autonomy, ${ }^{208}$ is now read as restricting Member State authority to regulate their courts. ${ }^{209}$ In-

205. See Prechal, supra note 43, at 157 n.71. Certain cases, however, cite the principle of effectiveness and the principal of effective judicial protection as though they are separate doctrines, which would go a long way toward ensuring the former's demise. Id. at 160 (citing Case 87 through 89/90, Verholen v. Sociale Verzekeringsbank Amsterdam, 1991 E.C.R. 3757, [1994] 1 C.M.L.R. 157 (1991)).

206. See Gardner, supra note 197, at 280; see also Arnull, supra note 137, at 22 ("In the light of cases like Factortame I and Francovich, it might be asked whether the Court still adheres to that view."); Caranta, supra note 21, at 716-17 (“[C]ompetence of Member States gradually but surely ceases to be a principle, and becomes the rule only in the absence of relevant Community provisions, inter alia judge-made rules."); Peter Oliver, State Liability in Damages Following Factortame III: A Remedy Seen in Context, in New Directions in European Public Law, supra note 25, at 50 (noting that while Rewe-Zentral- ${ }^{\text {nanz }}$ indicated that Community law was not intended to create new remedies, "[s]ubsequent rulings of the Court have cast the principles of effectiveness and non-discrimination so broadly that this statement has more or less been distinguished out of existence.").

207. See Marshall II, 1993 E.C.R. I-4367, [1993] 3 C.M.L.R. 293 (1993). In Marshall II, the Court—drawing on Francovich, but reading it more aggressively than did the Advocate General - held that in cases of dismissals contrary to Community law, equality required either reinstatement or anancial compensation, and that any compensation must be "full," subject neither to caps nor to restrictions on interest. Id. at III 25, 28, 32. Compare id. at II 37 (invoking Francovich), with id. at 310-12, 318-19 (suggesting that following Francovich, question remained whether compensation permitted by national law was "adequate," and that ordinarily national law caps on compensation, but not restrictions on the amount of postjudgment interest, would be permissible).

Marshall II clearly departs from the more topical precedent. It does not cite Johnston, perhaps re ${ }^{\circ}$ ecting a distinction between cases preserving judicial control over administrative actions and those relating to more traditional judicial remedies. Cf. Cases C-87 to 89/90, Verholen v. Sociale Verzekeringsbank Amsterdam, 1991 E.C.R. 3757, If 24, [1994] 1 C.M.L.R. 157, II 24 (1994); see also Case C-222/86, UNECTEF v. Heylens, 1987 E.C.R. 4098, If 14. The Court seems to distinguish Von Colson because it concerned a refusal-to-hire, rather than a dismissal claim, but that distinction was squarely rejected by the Advocate General in a subsequent case. See Opinion of Advocate General Léger, Case C-180/95, Draehmpaehl v. Urania Immobilienservice OHG, 1997 E.C.R. 2195, 2206-10, [1997] 3 C.M.L.R. 1107, 1117-20 (1997). Under any reading, Marshall II limits the force of Von Colson's observation that the directive "does not require any speciac form of sanction."

208. See, e.g., Case 33/76, Rewe-Zentral-"nanz, 1976 E.C.R. 1989 at II 5, [1977] 1 C.M.L.R. at 550 (1977); see also Opinion of Advocate General Warner, Case 33/76, ReweZentral-ananz, 1976 E.C.R. at 2002-03, [1977] 1 C.M.L.R. at 546-47 (1976); Case 50/76, Amsterdam Bulb, 1977 E.C.R. 137, II 33, [1977] 2 C.M.L.R. 218 (1977).

209. See Marshall II, 1993 E.C.R. I-4367, IIII 36-37, [1993] 3 C.M.L.R. 293, IIII 36-37 (1993); John Temple Lang, Community Constitutional Law: Article 5 EEC, 27 Common Mkt. L. Rev. 645, 650, 653 (1990); see also infra text accompanying note 396 (noting interpretive latitude afforded by Article 10 (ex art. 5)). The Court views social security beneats, which are administered by special tribunals on bases other than reparation, somewhat differently. See Case C-66/95, The Queen v. Secretary of State for Social Security, ex parte Sutton, 1997 E.C.R. I-2163, IIII 23-24, [1997] 2 C.M.L.R. 382, III 23-24 (1997) (Marshall II does not require interest to be paid on social security bene $e^{\mathrm{a}}$ arrears arising due to discrimination based on sex). As discussed below, this judgment may have been in ${ }^{\circ}$ uenced by the potential availability of state liability in Sutton. 
deed, in its recent decisions in Peterbroeck and van Schijndel, the Court appeared to convert the question of whether national law was suf ${ }^{\mathrm{a}}$ cient to protect Community rights into a more intrusive (and highly erratic) inquiry into whether national law was really worth preserving at all. ${ }^{210}$

The result is an emerging norm of homogeneity in national remedies. Recalling Lord Dennings's warning in 1974 that Community law was creeping "into the estuaries and up the rivers" of England, Professors Curtin and Mortelmans observe that it has since "partially burst its banks and is now rushing in great gulps into surrounding countryside, with all the inherent risks not only for the unprepared countryfolk, unfamiliar with its vigour and its thrust, but also for their long familiar national landscape and monuments." 211 The metaphor also bursts its banks, but it is certainly true that England is starting to look more and more like Holland.

For its part, Francovich plainly swept aside existing national laws restricting state liability, particularly those concerning legislative liability. ${ }^{212}$ By expressly promulgating a Community law rule, rather than a baseline for national remedies, the Court appeared to create "a rule which is necessarily identical in all Member States," 213 an impression it con ${ }^{\mathrm{a}}$ rmed by importing the standard de-

210. Compare C-312/93, Peterbroeck, 1995 E.C.R. I-4599, [1996] 1 C.M.L.R. 793, 799 (1996) (holding that national rule limiting the period during which a litigant (or the court, on the litigant's behalf) could raise an issue of Community law was regarded as not "reasonably justiable by principles such as the requirement of legal certainty or the proper conduct of procedure.") with Case C-430 \& C-431/93, van Schijndel, 1995 E.C.R. I-4705, IIT 19-20 [1996] 1 C.M.L.R. 801, IIII 19-20 (wholesale ban on the raising of issues sua sponte was entirely defensible). How the Court could reach such plainly inconsistent results in judgments rendered on the very same day is a puzzle. For representative head-scratching, see Gráinne de Búrca, National Procedural Rules and Remedies: The Changing Approach of the Court of Justice, in Remedies for Breach of EC Law, supra note 137; Hoskins, Tilting the Balance, supra note 39, at 375; Sacha Prechal, Community Law in National Courts: The Lessons from Van Schijndel, 35 Common Mkt. L. Rev. 681, 691(1998); Smith, supra note 76, at 314-16, Walter van Gerven, Bridging the Unbridgeable: Community and National Tort Laws After Francovich and Brasserie, 45 Int'l \& Comp. L.Q. 507, 513-16, 515 n.36 (1996). The best explanation, one strikingly consistent with the argument made elsewhere in this Article, is that Peterbroeck involved a state defendant, necessitating greater intervention on the Community's part. Cf. Leo Flynn, Taking Remedies Too Seriously? National Procedural Auto nomy in the European Court of Justice, 31 Irish Jurist 110, 129 (1996) (suggesting that van Schijndel result may apply "in cases where the State is itself a party to the dispute, necessitating a more active role for the national court"); see also Opinion of Advocate General Jacobs, Case C-2/94, Denkavit Internationaal v. Kamer van Koophandel en Fabrieken voor Midden-Gelderland, 1996 E.C.R. I-2827, 2846-50, [1996] 3 C.M.L.R. 504, 521-23 (1996) (discussing Peterbroeck). The van Schijndel approach has not been emphasized in subsequent cases, but even more abrupt and intrusive approaches have. See Prechal, supra note 43, at 692-93 (citing cases).

211. See Curtin \& Mortelmans, supra note 30, at 455 (quoting Bulmer Ltd. v. Bollinger $S A$, [1974] 1 Ch. 401, 418).

212. See Curtin, supra note 136, at 732-33; Steiner, supra note 152, at 12-19; Waelbroeck, supra note 179, at 325-26.

213. See Caranta, supra note 21 , at 713. 
veloped for Article 215 cases. ${ }^{214}$ Moreover, because state liability principles apply to so many different circumstances, they provide frequent opportunities for normalizing all the rules of national law-procedure, jurisdiction, standing, and so forth - that have the potential to preclude recovery on Community law grounds. ${ }^{215}$ To supporters and critics alike, Francovich fairly demands a new level of uniformity in European law, one detached for the ${ }^{\text {a }}$ rst time from the bases of direct applicability and direct effect..$^{216}$

Just how much of an impact Francovich may have is still up in the air. In Francovich, the Court described the availability of a damages remedy as a mere "reservation" to the ordinary autonomy of Member State legal orders, to be applied together with the nondiscrimination and effectiveness principles. ${ }^{217}$ But the broad potential of the liability remedy may enable litigants to overcome the limits that procedural autonomy places on other remedies. In Société Comateb, ${ }^{218}$ the Court held that while precluding repayment of import charges passed on to others was compatible with the Community right to restitution, traders might still seek damages under national law, augmented by Francovich, for any resulting injury to their sales. ${ }^{219}$ Likewise, Sutton ${ }^{220}$ held that even though the United Kingdom's practice of withholding interest on unlawfully delayed social security beneats did not breach a directive's remedial provisions, interest might still be recovered if it resulted from the government's underlying failure to implement that directive properly in the ${ }^{\text {arst }}$ place. ${ }^{21}$ State liability may thus serve to overcome obsta-

214. See, e.g., Waelbroeck, supra note 179, at 324 (arguing against adoption of Article 288 (ex art. 215) standard on ground that it fails to respect national distinctions between legislative and administrative acts).

215. See Caranta, supra note 21 , at 714-15 (arguing that the move toward Community law rules in Francovich "makes possible the creation of a body of procedural rules common to Member States; it contributes to the equalization of national practice"); see also Opinion of Advocate General Jacobs, Case C-88/95, Fantask A/S v. Industriministeriet (Ehrverministeriet), 1997 E.C.R. I-6783, II 78-84, [1998] 1 C.M.L.R. 473, III 78-84 (1998).

216. Cf. Curtin \& Mortelmans, supra note 30 , at 435 (discussing principle of uniform application of secondary Community law and exceptions).

217. See Cases C-6/90 \& C-9/90, Francovich v. Italy, 1991 E.C.R. I-5357, III 42-43, [1993] 2 C.M.L.R. 66, III 42-43 (1991). The Court subsequently reviewed the Italian scheme for providing government compensation for its insolvency directive lapses on precisely those bases. See Case C-261/95, Palmisani v. INPS, [1997] 3 C.M.L.R. 1356 (1997); Case C373/95, Maso v. INPS, [1997] 3 C.M.L.R. 1244 (1997).

218. Case C-192/95 to 218/95, Société Comateb v. Directeur General des Douanes et Droits Indirects, 1997 E.C.R. I-165, [1997] 2 C.M.L.R. 649 (1997).

219. Id. at III 27, 34 ("Furthermore, traders may not be prevented from applying to the courts having jurisdiction, in accordance with the appropriate procedures of national law, and subject to the conditions laid down in [Brasserie] for reparation of loss caused by the levying of charges not due, irrespective of whether those charges have been passed on.").

220. Case C-66/95, Regina v. Secretary of State for Social Security, ex parte Sutton, 1997 E.C.R. I-2163, [1997] 2 C.M.L.R. 382 (1997).

221. Sutton, [1997] 2 C.M.L.R. at III 20-35. The availability of state liability seems to have encouraged the Court to read the directive's terms relatively narrowly, at least as com- 
cles confronting other remedies, and perhaps to repair injury caused by the imposition of the procedural limits themselves.

Some European scholars have embraced this homogenization of national law as a desirable, and even central, objective of the case law. ${ }^{222}$ The most prominent and proli ${ }^{\mathrm{a}} \mathrm{c}$ exponent of this view is Walter van Gerven, former advocate general at the Court of Justice, who has repeatedly emphasized that remedies must be both adequate and comparable enough to prevent varying judicial protection across Member States. ${ }^{223}$ Van Gerven forthrightly acknowledges the tension with the "so-called principle of the autonomy of the member States in matters of procedural law," not to mention the ReweZentral- ${ }^{a}$ nanz/Comet standard, but appears to regard the only legitimate obstacle to "sufacient harmonization" as practical politics. ${ }^{224}$ Thus, according to van Gerven, the Court's "creative function in developing Community law" should primarily rely on common national principles to avoid inciting Member State resistance to the Community tide. ${ }^{225}$

Achieving meaningful homogeneity in Europe is a formidable task. ${ }^{226}$ But Francovich may help achieve it by in ${ }^{\circ}$ uencing Member State remedies for violations of national law. National courts, especially those that were slow to recognize the supremacy and direct effect of Community law, have been loathe to afford more vigorous

pared to its pre-Francovich precedent. See id. at II 21 (noting "practically identical" language of Equal Treatment Directive, construed in Marshall II as requiring interest on damages awards); $c f$. Oliver, supra note 206, at 59-61 (criticizing distinction in Sutton as inconsistent with principle of effectiveness).

222. See, e.g., Tash, supra note 76; see also Francis Jacobs, Remedies in National Courts for the Enforcement of Community Rights, in Liber Amicorum for Don Manuel Diez de Velasco 969 (1993), quoted in van Gerven, supra note 210, at 514 n.29.

223. See Walter van Gerven, Mutual Permeation of Public and Private Law at the Nitional and Supranational Level, 5 Maastricht J. Eur. \& Comp. L. 7 (1998); see also van Gerven, supra note 210, at 513-16, 520; Walter van Gerven, Bridging the Gap Between Community and National Laws: Towards a Principle of Homogeneity in the Field of Legal Remedies?, 32 Common Mkt. L. Rev. 679, 690-95, 697-99 (1995); van Gerven, supra note 199.

224. See van Gerven, supra note 210, at 514-15; see also van Gerven, Bridging the Gap, supra note 223, at 693-95. He also notes the "even more unfortunate" suggestion in Francovich that Member States are to retain autonomy, subject to the principles of nondiscrimin ation and effectiveness, over a perhaps broader category of "substantive conditions" relating to liability, the content of which is unclear. See van Gerven, supra note 210, at 514-15.

225. See van Gerven, Mutual Permeation, supra note 223, at 23 (indicating that while both Court of Justice and European Court of Human Rights "make deep inroads into national rules, such as those regulating public authorities' non-contractual liability," they "should, however, ensure that the solutions put forward by them square with legal rules common to as many Member State legal systems as possible," lest "their case law may not be recognized and accepted, sociologically as well, in Member States"); van Gerven, supra note 139, at 46 (explaining that "political" considerations are most important warrant for seeking compat ibility with Member State law). Van Gerven also cites the need to reinforce legal homogeneity, economic integration, and promote the common culture. Id. at 46-47.

226. Anticipating this, van Gerven makes a point of showing some surprising degrees of agreement among national laws. See van Gerven, supra note 210, at 508-13. 
protection to Community law than to analogous provisions of mtional law. ${ }^{227}$ Restitution $^{228}$ and injunctive relief ${ }^{229}$ have begun to follow the Community law lead, and national liability principles appear to be heading down the same path. ${ }^{230}$ Because state liability applies to more circumstances, and has been made to rest on a principle of effective judicial protection, its gravitational pull will be much stronger.

The mounting centralization of European law is characteristic of federal systems. ${ }^{231}$ But it is more surprising to discover in the Community, given that its ${ }^{\circ} \mathrm{aw}$ as a federal system has always been its decentralization and control by Member States. Many, like van Gerven, view the erosion of this autonomy with equanimity, or even delight. Others conclude that no doctrine of state remedial autonomy ever existed, and that national law has always been interstitial in nature. ${ }^{232}$ It is certainly true that no adequate principle of autonomy exists. ${ }^{233}$ Moreover, the absence of any clear-cut basis for preferring national law has permitted the Court to stray from its original practice of deference without any meaningful end in sight. ${ }^{234}$

227. See van Gerven, Bridging the Gap, supra note 223, at 699-702; Roberto Caranta, Learning from our Neighbours: Public Law Remedies Homogenization from Bottom Up, 4 Maastricht J. Eur. \& Comp. L. 220, 223 (1997) (observing that once Community law guaranteed interim relief, "[n]ational courts felt compelled to offer the same kind of remedies irrespective of the source, Community or national, of the rights vindicated through the judicial process); Caranta, supra note 21, at 717-18. As Roberto Caranta observes, however, more than mere catch-up may be at stake; to some scholars, extending the same remedies to national law rights is required by a legal duty to avoid treating similar situations dissimilarly. See Caranta, Learning From Our Neighbours, supra, at 223-24.

228. See, e.g., Woolwich Equitable Bldg. Soc'y v. IRC, [1992] 3 All E.R. 737, 764 (Lord Goff) ("[A]t a time when Community law is becoming increasingly important, it would be strange if the right of the citizen to recover overpaid charges were to be more restricted under domestic law than it is under Community law).

229. Lord Woolf noted that following Factortame, "the unhappy situation exists that while a citizen is entitled to obtain injunctive relief (including interim relief) against the Crown or an of ${ }^{a}$ cer of the Crown to protect his interests under Community law, he cannot do so in respect of his other interests which may be just as important." M v. Home Oface, [1994] 1 App. Cas. 377, 407, [1993] 3 All E.R. 537, [1993] 3 W.L.R. 433. In changing course, Lord Woolf further remarked that "[i]t would be most regrettable if an approach which is inconsistent with that which exists in community should be allowed to persist if this is not strictly necessary." [1994] 1 App. Cas. at 463. Though the English reversal was more dramatic, Spanish courts also did an about-face. See Caranta, Learning from our Neighbours, supra note 227 , at 225 .

230. See Waelbroeck, supra note 12 , at 476.

231. See Jenna Bednar, John Ferejohn, \& Geoffrey Garrett, The Politics of European Federalism, 16 Int'l Rev. L. Econ. 279, 281-82 (1996).

232. See Kakouris, supra note 27. This argument relies, however, on a rather selective reading of the case law, and elides the difference between permitting application of national law "only insofar as it ensures the effective application of substantive Community law," see $i d$. at 1405 , and establishing Community law only upon a showing of necessity-the difference, in essence, between proportionality and subsidiarity.

233. See, e.g., Chalmers, supra note 60, at 184-90.

234. Cf. Arnull, supra note 137, at 23 ("The remarks in 'Butter-buying cruises' should therefore be regarded merely as a general statement of principle which is subject to various 
As the following section demonstrates, this drift seems, at ${ }^{2}$ rst blush, to con ${ }^{\circ}$ ict with the Community's respect for Member State alternatives, best captured by the newly enshrined subsidiarity principle.

\section{BRINGING JUDICIAL SUBSIDIARITY INTO FOCUS}

Although the notion of subsidiarity has a long religious and political pedigree, its formal incorporation into Community law has been relatively abrupt and strikingly awkward. ${ }^{235}$ After an inauspicious debut ${ }^{236}$ and a minor role in the Single European Act in $1987,{ }^{237}$ subsidiarity assumed a prominent place in the Maastricht Treaty, where it was hailed by some as the Treaty's savior ${ }^{238}$ and derided by others as a concept utterly devoid of meaning. ${ }^{239}$ Even

derogations, the scope of which is now becoming clearer. Indeed, it would be surprising if the general principle applied even where its effect would be to frustrate the proper implementation of Community law or prejudice the rights of individuals.").

235. According to one estimate, "[s]ubsidiarity may be the most contentious abstract noun to have entered European politics since 1789." Centre for Economic Policy Research, Making Sense of Subsidiarity: How Much Centralization for Europe? 1 (1993). For thorough reviews of this history from a legal perspective, including brief comment on its theological background, see Deborah Z. Cass, The Word That Saves Maastricht? The Principle of Subsidiarity and the Division of Powers Within the European Community, 29 Common Mkt. L. Rev. 1107, 1111-28; see also Nicholas Emiliou, Subsidiarity: An Effective Barrier Against “the Enterprises of Ambition”?, 17 Eur. L. Rev. 383, 391-99; Paul Marquardt, Subsidiarity and Sovereignty in the European Union, 18 Fordham Int'1 L.J. 616, 618-28 (1994); A.G. Toth, The Principle of Subsidiarity in the Maastricht Treaty, 29 Common Mkt. L. Rev. 1079, 1088-91 (1992). For accounts provided greater detail on the political background, see John Peterson, Subsidiarity: A De anition to Suit Any Vision?, 47 Parliamentary Aff. 1 (1994); Kees van Kerbergen \& Bertjan Verbeek, The Politics of Subsidiarity in the European Union, $32 \mathrm{~J}$. Common Mkt. Stud. 215 (1994); Ward, supra note 18.

236. The term a rst popped up in the Commission's 1975 Report on Economic Union, see Commission of the European Communities, Report on European Union, 8 E.C. Bull., No. 6 (Supp. 5) (1975), before playing a role in the Parliament's failed draft European Treaty of 1984. See Draft Treaty Establishing the European Union, arts. 9, 12, 1984 O.J. (C 77) 33.

237. See Single European Act, art. 130r(1), (4), 1987 O.J. (L 169) 1, [1987] 2 C.M.L.R. 741.

238. See, e.g., Hans-W. Micklitz \& Stephen Weatherill, Federalism and Responsibility, in Federalism and Responsibility: A Study on Product Safety Law and Practice in the European Community 30 (Hans-W. Micklitz et al. eds., 1994).

239. Margaret Thatcher is supposed to have called it "gobbledegook," see Phillip Howard, Column, Times, Oct. 15, 1992, at 16, at about the time her successor, John Major, was extolling its virtues. Lord Mackenzie-Stuart seconded Thatcher's view, see Lord MackenzieStuart, A Formula for Failure, Times (London), Dec. 11, 1992 ("'gobbledygook"), before branching out somewhat. See Lord Mackenzie-Stuart, Subsidiarity-A Busted Flush, in Constitutional Adjudication, supra note 191, at 19, 24 ("[R]uin upon ruin, rout upon rout, confusion worse confounded"); Andrew Andonis \& Andrew Tyrie, Twelve Men in Search of a Common Meaning, Fin. Times, Dec. 7, 1992, at 17 ("The paragraph on subsidiarity is a disgraceful piece of sloppy draftsmanship, so bad that one is forced to assume it must be deliberate." (quoting Lord Mackenzie-Stuart, Foreword, in Andrew Adonis \& Andrew Tyrie, Subsidiarity: No Panacea (European Policy Forum, 1992)).

Much academic opinion is equally severe. Toth, for his part, suggests that "there are few concepts in the Maastricht Treaty, or indeed in Community law as a whole, which are more elusive than the concept of subsidiarity," and notes that President Jacques Delors offered a 
the Commission ventured that subsidiarity was more of a "state of mind" than anything concrete. ${ }^{240}$

In fact, considerable effort has gone into elaborating on the meaning of subsidiarity. Vague invocations are scattered throughout the Treaty's preamble 241 and in various operative parts of the Treaty, ${ }^{242}$ but the truly operative subsidiarity principle is set out in paragraph 2 of Article 5 (ex art. 3b):

In areas which do not fall within its exclusive competence, the Community shall take action, in accordance with the principle of subsidiarity, only if and in so far as the objectives of the proposed action cannot be sufaciently achieved by Member States and can therefore, by reason of the scale or effects of the proposed action, be better achieved by the Community.

Paragraph 3, which is formally considered to capture the principle of proportionality, further provides that "[a]ny action by the Community shall not go beyond what is necessary to achieve the objectives of this Treaty."

The Commission and the Council delivered post-Maastricht $\mathbf{e}$ ports explaining both the principle of subsidiarity and the principle of proportionality, ${ }^{243}$ as did Member States-in particular, in the

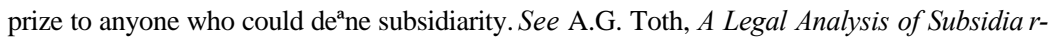
ity, in Legal Issues of the Maastricht Treaty, supra note 40, at 37; see also Guenther F. Schaefer, The Rise and Fall of Subsidiarity, 23 Futures 681, 688 (1991) ("[S]ubsidiarity is basically an empty shell devoid of concrete substance.”).

240. See Commission of the European Communities, Commission Report to the European Council on the Adaptation of Community Legislation to the Subsidiarity Principle, COM (93) $545^{\text {anal at }} 2$ (Nov. 24, 1993) [hereinafter Commission Subsidiarity Report].

241. Article 1 of the Treaty on European Union declares that in the European Union "decisions are taken as openly as possible and as closely as possible to the citizen," and Article 2 generally requires the Community to pursue Treaty objectives "while respecting the principle of subsidiarity as de ${ }^{a}$ ned in Article 5 [ex art. 3b]." TEU arts. 1 (ex art. A), 2 (ex art. B).

242. In general, these provide that in areas newly opened to Community action Member States are to continue exercising primary responsibility. See EC Treaty art. 149(1) (ex art. 126(1)) (teaching and education), 150(1) (ex art. 127(1)) (vocational training), 151(1) (ex art. 128(1)) (culture), 152(1) (ex art. 129(1)) (health), 153(1) (ex art. 129a(1)) (consumer protection), 164 (ex art. 130g) (industrial policy); TEU art. 31 (ex art. K.3) (cooperation in justice and home affairs); see also Agreement on Social Policy Concluded Between Member States of the European Community with the Exception of the United Kingdom of Great Britain and Ireland, arts. 1, 2; see generally Annex to part A, Overall Approach to the Application by the Council of the Subsidiarity Principle and Article 3b of the Treaty on European Union, European Council in Edinburgh-11 and 12 December 1992 - Conclusions of the Presidency (Press Release, Commission of the European Communities, Dec. 13, 1992), reprinted in 25 E.C. Bull., No. 12, at 12, 13 \& n.3 (1992) [hereinafter Edinburgh Conclusions]; Bermann, supra note 2, at 346 .

243. See Interinstitutional Declaration on Democracy, Transparency and Subsidiarity, 26 E.C. Bull., Oct. 1993, at 118 (1993) [hereinafter Interinstitutional Declaration]; European Commission, Communication on the Principle of Subsidiarity for Transmission to the Council and Parliament, 25 E.C. Bull., Oct. 1992, at 116 (1992) [hereinafter Subsidiarity Communication]; Commission Subsidiarity Report, supra note 240; Report to the European Council 
conclusions issued following a December 1992 meeting of the Council at Edinburgh, ${ }^{244}$ and in the protocol emerging from the 1996 intergovernmental conference and attached to the Amsterdam Treaty. ${ }^{245}$ These add substantially to the understanding of Article 5. But they offer strikingly little information about the role of the Court of Justice, an institution clearly experienced at legal interpretation. Subsidiarity, viewed through the lens of proportionality, is a doctrine suf ${ }^{a}$ ciently coherent to permit judicial application; $\mathrm{n}$ deed, the Court is obliged to heed it, at least to the extent of reexamining its approach to remedies.

\section{A. The Meaning of Subsidiarity}

\section{Subsidiarity Proper}

According to Article 5, subsidiarity permits Community action only when Member States cannot achieve the desired action. This is immediately qualiaed, however, by some sort of comparative advantage analysis: where Member State action will not suf ${ }^{\mathrm{a}} c e$, it is because it can "by reason of the scale or effects of the proposed action, be better achieved by the Community."

The potential inconsistency between these two limbs is obvious-highlighted, rather than hidden, by the wishful assertion that one "therefore" follows from the other-and seems to have been a purposeful, if oawed, attempt to reconcile intractable political differences. ${ }^{246}$ As vetted in the literature, subsidiarity might mean that

on the Application of the Subsidiarity Principle, COM (94)533 ${ }^{\text {a }}$ nal, November 25, 1994.

244. See Edinburgh Conclusions, supra note 242.

245. See Amsterdam Protocol, supra note 16; U.K. Memorandum, supra note 22; see also Summary of Positions of Member States with a View to the 1996 Intergovernmental Conference, in II White Paper on the 1996 Intergovernmental Conference <http://europa.eu.int/en/agenda/igc-home/eu-doc/parlment/peen2.htm>.

246. The common account is that while the Germans, Dutch, and French preferred a version of subsidiarity in which the Community would be entitled to act whenever it had a comparative advantage, the British held out for an interpretation under which Community action would be permissible only when necessary or essential, and ultimately the two were cobbled together. See Centre for Economic Policy Research, supra note 235, at 20; Jason Coppel, Edinburgh Subsidiarity, 44 N. Ireland Legal Q. 179, 181 (1993); Dashwood, supra note 34, at 115 . This is supported by the drafting history, such as it is; certainly, the comparative advantage approach was consistently followed in the Final Declaration of the Conference of Parliaments of the European Community (the "Assizes") of November 30, 1990, see The Treaty of Maastricht 200 II 23 (Richard Corbett ed., 1993); the Luxembourg Presidency "Non-paper" of April 21, 1991, which served as the basis for negotiation and revision, see id at 269 (Article 3b); the failed Dutch Presidency draft of September 24, 1991, id. at 329 (Article 2a); the Dutch Presidency draft of November 8, 1991, id. at 349 (Article 3b); and the Dutch Presidency Note of the Noordwijk Conclave of Foreign Ministers, November 12-13, $1991, i d$. at 375.

The slightest drafting change would have made this all much easier. It is hard to imagine much puzzlement or discord, for example, were the ${ }^{\mathrm{a}} \mathrm{rst}$ limb of Article 5(2) reformulated so that the Community was entitled to act "only if and in so far as the objectives of the proposed action cannot suf"ciently be achieved by Member States," or better still, "only if and in so far 
Community action is legitimate when (a) Member States cannot suf ${ }^{a}$ ciently achieve the objectives in question (a "necessity" test), (b) Community action better achieves the indicated objective (a "better achievement" test), (c) Community action is more ef cient in achieving the same or better result (an "ef ciency" test), or (d) some, all, or none of the above. 247

Worrying about the difference between the "necessity" and "better achievement" tests seems unproductive. The second limb of Article 5 must be given some meaning, lest it be rendered surplusage. ${ }^{248}$ The Amsterdam Protocol also endorses applying the limbs conjunctively. ${ }^{249}$ So long as the touchstone is a narrowly de ned policy objective, the result actually seems coherent-Member State action does not get the job done (and therefore should not be pursued) and Community action is permissible because it does better (if not, neither should take action).250

The larger problem is the prospect of "efa ciency" justiacations, which might warrant Community action based on factors extrinsic to the action's objective, e.g., cost savings, or the prevention of other harms. ${ }^{251}$ Thus, the Commission's communication states that

as action by Member States would be insuf ${ }^{a}$ cient to achieve the objectives of the proposed action."

247. For a comparable breakdown, see Josephine Steiner, Subsidiarity Under the Maastricht Treaty, in Legal Issues of the Maastricht Treaty, supra note 40.

248. See Coppel, supra note 246, at 181.

249. See Amsterdam Protocol, supra note 16, at 106 II 5 ("For Community action to be justiaed, both aspects of the subsidiarity principle shall be fullalled") (emphasis added).

250. There are a variety of other ways to parse the language-for example, the second limb might be considered exemplary, disjunctive, or a means by which necessity is evaluated - but the most sensible methods arrive at the same result. If, for example, the second limb is exemplary (that is, the superiority of Community action is mentioned as one case in which Member State action would be insuf ${ }^{\mathrm{a}}$ cient), this suggests that better achievement is the real benchmark, and that the mere fact that Community action is unnecessary is not a compelling reason to deprive it of the power to act. Alternatively, the second limb might be read as addressing the question of how to measure what is necessary, or what "suf acient achievement" really constitutes. See Coppel, supra note 246 , at 182 . The proper question, invariably, would be which level better achieves the end in question (if on the other hand, the "better achievement" test is conceived of as an inquiry into ef ciency, one can imagine the tests overlapping only in part: an action may be necessary, even if inef ${ }^{a}$ cient, and may be ef ${ }^{a}$ cient even if unnecessary). See Centre for Economic Policy Research, supra note 235, at 20.

This need to have reference to Community superiority is perhaps even clearer in legislative applications, where the Community will be able to deane the objectives of the action so as to indicate that the objectives include maximum, or perhaps optimum, attainment, and since such objectives are the touchstone for subsidiarity, circumvent thereby any distinction. See Lenaerts, supra note 17, at 877. As Judge Lenaerts notes, this power also permits the Co mmunity to incorporate a broader sense of ef ${ }^{a}$ ciency among its objectives, and as such raises difacult questions.

251. For example, one assessment of subsidiarity's application in the environmental arena stressed the need to consider "psychic" spillovers, i.e., the beneats of an untrammeled environment to those people who may never see, use, or visit (let alone cast votes affecting) the area. See W.P.J. Wils, Subsidiarity and EC Environmental Policy: Taking People's Concerns Seriously, 6 J. Envt'1 L. 85, 89-91 (1994). 
Article 5 contains a "test of comparative ef ciency between Community action and that of Member States" involving not only the examination of whether other means are "sufacient" to attain the objectives, but also such nebulous considerations as "the cost of inaction" and "the necessity to maintain a reasonable coherence." 252 The Amsterdam Protocol, following the Edinburgh Guidelines closely, tends to disassociate the possible justiacation for Community action from its central objectives-when the one thing that Article 5(2) is clear about was the importance of assessing subsidiarity solely in those terms. The Protocol raises the specter that Community action can survive a subsidiarity analysis if anything substantial may be said for it.

But the three bases for Community action described in the Amsterdam Protocol are also susceptible of narrower reading. The ${ }^{\text {a }}$ rst indicates that Community action may be required where the issue has "transnational aspects" that Member States cannot satisfactorily regulate. This sort of externality, or spillover, is not only a traditional warrant for central intervention, but is also one of the most common Community regulatory objectives. ${ }^{253}$ In this regard, the guidelines add little to what the more restrictive view of Article 5 seems to demand.

The second basis for Community action is where "actions by Member States alone or lack of Community action would con ${ }^{\circ}$ ict with requirements of the Treaty (such as the need to correct distortion of competition or avoid disguised restrictions on trade or strengthen economic and social cohesion) or otherwise signi ${ }^{\mathrm{a}}$ cantly damage Member States' interests." Although the Protocol's cited examples of Treaty "requirements" look quite broad, the underlying focus on "signia"cant" damage to Member State interests suggests that the relevant Treaty-based bene ${ }^{a}$ ts must pertain to federalism.

The Amsterdam Protocol's third basis is the broadest: Community action may be sustained where it "would produce clear bene ${ }^{a}$ ts by reason of its scale or effects" over Member State action. Together with the requirement that any damage to Member States

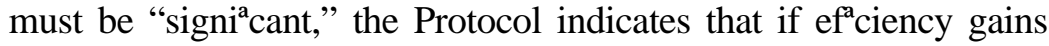
are supposed to justify Community action, they must be demonstrable and persuasive. Read this way, the Amsterdam Protocol's three guidelines are consistent with a strong presumption in favor of Member State action.

Such a presumption is consistent with values behind subsidiarity, which assume that employing Member States is worthwhile inde-

252. See Subsidiarity Communication, supra note 243, at 116.

253. See, e.g., Centre for Economic Policy Research, supra note 235, at 36; Inman \& Rubinfeld, supra note 2, at 7. 
pendent of their relative effectiveness at achieving regulatory $\mathrm{d}$ jectives. ${ }^{254}$ The ambition most consistently claimed for subsidiarity is to ensure that decisions are "taken as closely as possible to the citizen," ${ }^{255}$ so as to establish "greater democratic control." 256 According to orthodox federalism, greater localism increases the opportunity for individual participation, which means that the rules will more likely re ${ }^{\circ} e c t$ the population's interests, which is valuable in its own right. ${ }^{257}$ The democratic advantage of European localism is enhanced by the democratic de cit characterizing Community institutions, and the lack of any genuine demos at the Community level. ${ }^{258}$

The Edinburgh Conclusions also emphasized, in language not

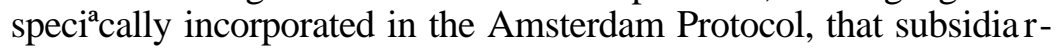
ity "contributes to the respect for the national identities of Member States and safeguards their powers." 259 Intensive harmonization

254. Instead of claiming that subsidiarity should be pursued because of some intrinsic worth, this Article takes subsidiarity as a deliberate political choice made by the Community, and sees how best to respect the ends it seeks. To the extent that subsidiarity was adopted because of its ability to achieve certain goals, or because of its embodiment of certain values, it should be the task of the judiciary-all things being equal-to promote those goals or values in applying subsidiarity. For a thoughtful, if abstract, defense of reading Article 5(2) broadly, see Schilling, supra note 34, at 216-17; see also Nanette A. Neuwahl, A Europe Close to the Citizen? The 'Trinity Concepts' of Subsidiarity, Transparency and Democracy, in A Citizen's Europe: In Search of a New Order 51-54 (Allan Rosa \& Esko Antola eds., 1995).

255. See TEU art. 1 (ex art. A); Amsterdam Protocol, supra note 16, at 105; see also Edinburgh Conclusions, supra note 242, at 13; Subsidiarity Communication, supra note 243, at 116.

256. See Subsidiarity Communication, supra note 243, at 116.

257. See Bermann, supra note 2, at 340; Inman \& Rubinfeld, supra note 2, at 6; see also Robert P. Inman \& Daniel L. Rubinfeld, Making Sense of the Antitrust State-Action Doctrine: Balancing Political Participation and Economic Ef ${ }^{a}$ ciency in Regulatory Federalism, 75 Texas L. Rev. 1203, 1211-17 (1997).

258. See, e.g., Bermann, supra note 2, at 340 n.20; Neuman, supra note 2, at 575-76; J.H.H. Weiler et al., European Democracy and Its Critique, 18 W. Eur. Pol. 4 (1995); Antje Wiener \& Vincent Della Salla, Constitution-Making and Citizenship Practice-Bridging the Democracy Gap in the EU, 35 J. Common Mkt. Stud. 597 (1997). For an evaluation of the absence of conventional democracy at the European level, see Deirdre M. Curtin, Postnational Democracy: The European Union in Search of a Political Philosophy (1997).

259. See Edinburgh Conclusions, supra note 242, at 13. It is not easy to assess how much separate weight to give the Edinburgh Conclusions. The Court of Justice has not been terribly helpful. See Opinion of Advocate General Léger, Case C-233/94, Germany v. European Parliament (Re. Deposit Guarantee Directive), [1997] 3 C.M.L.R. 1379, II 88 (citing Edinburgh Conclusions as authority in construing subsidiarity), id. at IIII 150, 152-53 (proportionality); Case C-233/94, Germany v. European Parliament (Re. Deposit Guarantee Directive), [1997] 3 C.M.L.R. 1379, II 80 ( ${ }^{a}$ nding it unnecessary, in resolving proportionality objection, "to determine the precise legal value of the conclusions of the European Council in Edinburgh on which the German Government relies"). The Court rarely relies on drafting history or extrinsic materials when interpreting the Treaty. See Coppel, supra note 246, at 183 n.13; Dubinsky, supra note 4, at 310; Nanette A. Neuwahl, A Europe Close to the Citizen? The 'Trinity Concepts' of Subsidiarity, Transparency and Democracy, in A Citizen's Europe: In Search of a New Order 47-48 (Allan Rosa \& Esko Antola eds., 1995); see also Toth, supra note 22, at 278 (Court of Justice, not European Council, has authority to interpret Treaty). 
may, of course, be in tension with preserving distinctive national identities. ${ }^{260}$ The concern for "safeguarding powers" suggests a further desire to preserve the political identities of the states-to preserve, in other words, a sphere for national action, or autonomy, otherwise exposed under the Treaty. Such autonomy might serve to promote liberty by preserving a balance of power between levels of government, ${ }^{261}$ allowing decentralized adaptation, ${ }^{262}$ and encouraging innovation. ${ }^{263}$

The overall effect of subsidiarity, therefore, is not to de ${ }^{\mathrm{a}}$ ne speciac powers or subject matter that are to be kept for the states. Instead, the subsidiarity principle generally presumes that all subject matter open to regulation by Member States should be regulated by them. Community action is permissible, in sum, when the nature of the problem is such that Member States cannot regulate, or when it offers "clear" and "signi" cant" advantages that may inure to Member States' interests.

It should perhaps be stressed that, just as Article 5 does not assign specia ${ }^{\mathrm{a}} \mathrm{c}$ areas to Member States, it equally does not assign authority to any other level of political authority-either below or above them. The failure to appreciate this has led to two different sorts of objections. To those familiar with the subsidiarity principle's traditional preoccupation with pushing authority as far down-

But the European Council's deliberations and eventual conclusions were important in ensuring rati ${ }^{\mathrm{a}}$ cation in the United Kingdom and Denmark, and might be considered instructive if only by virtue of that in ${ }^{\circ}$ uence. See The Treaty of Maastricht, supra note 246, at 72 . The Conclusions are more likely to be relevant, however, in interpreting the Amsterdam Protocol. Much of the Edinburgh Conclusions are repeated verbatim in the Amsterdam Protocol. More generally, the Protocol "con ${ }^{\mathrm{a}} \mathrm{rm}[\mathrm{s}]$. . . that the [Edinburgh Co nclusions] will continue to guide the actions of the Union's institutions as well as the development of the application of the principle of subsidiarity." Amsterdam Protocol, supra note 16, at 105. Presumably an exception may be made in the event of con $^{\circ}$ ict between the Edinburgh Conclusions and the Protocol itself.

260. See Ted M. de Boer, The Relation Between Uniform Substantive Law and Private International Law, in Towards a European Civil Code 60 (A.S. Hartkamp et al. eds., 1994). See generally Bermann, supra note 2 , at $341 \&$ n.25; Neuman, supra note 2, at 575. Article 6(3) of the Treaty on European Union, as amended, provides that "[t]he Union shall respect the national identities of its Member States." The concept of "national identities" is not clariaed, though some urge that it be construed as incorporating the protection of national constitutions. See Diarmuid Rossa Phelan, Revolt or Revolution: The Constitutional Boundaries of the European Community 160-62 (1997).

261. See Evan H. Caminker, State Sovereignty and Subordination: May Congress Commandeer State Of $f^{a}$ cers to Implement Federal Law?, 95 Colum. L. Rev 1001, 1074-75 (1995).

262. Cass, supra note 6, at 1114-15.

263. In the United States, this is known as the "laboratories of democracy" argument, commonly attributed to Justice Brandeis. See New State Ice v. Liebmann, 285 U.S. 262, 311 (1932) (Brandeis, J., dissenting) (“[A] single courageous state may, if its citizens choose, serve as a laboratory; and try novel social and economic experimentation without risk to the rest of the country."). But see Susan Rose-Ackerman, Risk Taking and Reelection: Does Federalism Promote Innovation?, 9 J. Legal. Stud. 593 (1980). 
ward as possible, ${ }^{264}$ the absence from Article 5 of any mention of the alternative of decentralized, $s u b$-national action was somewhat surprising. ${ }^{265}$ But Article 5 instead entrusts Member States with determining whether more decentralized action is preferable. The ability of sub-national regions to accomplish an objective in lieu of Community action may certainly be considered, ${ }^{266}$ and Member States are free to distribute national authority as they wish, but they are ultimately responsible for the execution of duties imposed on them by Community law. ${ }^{267}$ As a matter of subsidiarity, therefore, Community legislation should neither undermine a Member State's internal arrangements nor impose a principle of subsidiarity upon Member States themselves. ${ }^{268}$

The more persistent concern focuses on subsidiarity's potential for transferring power to the Community. ${ }^{269}$ Many have suggested, for example, that where the subsidiarity criteria are satis ${ }^{\mathrm{a}} \mathrm{ed}$, Community action should—or perhaps must—be undertaken. ${ }^{270}$ These

264. See, e.g., Bermann, supra note 2, at 342-43. As previously noted, Article 1 (ex art. A, after amendment) of the Treaty on European Union speaks generally of the need to push decision-making as close to the people as possible, but that principle is not enforceable by the Court of Justice to the same extent as Article 5. See Steiner, supra note 247, at 53.

265. See Gerry Cross, Subsidiarity and the Environment, 15 Y.B. Eur. L. 107, 108 (1995) ("The arst thing that must be stated with regard to Article [5] is that it enshrines what might be described as a 'sawn-off' form of subsidiarity. It is subsidiarity down as far as the national level but no farther."); see also Coppel, supra note 246, at 179 (noting emphasis by federal Member States on sub-national subsidiarity).

266. Thus, the pre-Amsterdam IGC noted a declaration by federal states re ${ }^{\circ} e c t i n g$ their understanding that the question of national-level feasibility includes their regions' authority. Declaration by Germany, Austria and Belgium on Subsidiarity, Amsterdam Treaty, supra note 16, at 143. These declarations followed the unsuccessful attempt by Germany to achieve express recognition of this corollary in the Mastricht Treaty. See Bart Hessel \& Kamiel Mortelmans, Decentralized Government and Community Law: Con icting Institutional Developments? , 30 Common Mkt. L. Rev. 905, 910 (1993).

267. The Amsterdam Treaty includes a separate declaration reiterating that administrative implementation of Community law "shall in principle be the responsibility of Member States in accordance with their constitutional arrangements." See Declaration Relating to the Protocol on The Application of the Principals of Subsidiarity and Proportionality (No. 43), Amsterdam Treaty, supra note 16 , at 140 . This is unsurprising. The Court has consistently held that Member States are permitted to adhere to their distinctive structures in discharging their Community responsibilities, see, e.g., Case 96/81, Commission v. The Netherlands, 1982 E.C.R. 1791, but that this has no effect on the ultimate responsibility of the Member State for any failures. See Hessel \& Mortelmans, supra note 266, at 916-17, 925-26. A small proportion of regional or other decentralized authority is actually addressed directly to them by Community instruments. See id. at 920-22.

268. See, e.g., Petes E. Herzog \& Hans S. Smit, The Law of the European Community: A Commentary on the EEC Treaty (1998), at I-64. Maastricht's creation of a new Committee of the Regions to advise in policy formulation may provide the regions with another avenue of in ${ }^{\circ}$ uence. See Hessel \& Mortelmans, supra note 266, at 913; Andrew Scott et al., Subsid $i$ arity: A 'Europe of the Regions' v. the British Constitution?, 32 J. Common Mkt. Stud. 47, 58-60 (1994).

269. Cf. Marquardt, supra note 235, at 635-39 (arguing that subsidiarity will catch states in a pincer movement between centralization and devolution to sub-national levels of society).

270. See, e.g., Centre for Economic Policy Research, supra note 235, at 4; Jacques Santer, 
concerns were substantiated to an unfortunate degree by the Commission's communication on subsidiarity ${ }^{271}$ and by the Edinburgh Conclusions. ${ }^{272}$ But the notion that subsidiarity expands Community authority is ${ }^{\circ}$ atly inconsistent with the objective of Article 5(2) and contraindicated by Article 5(1), which limits the Community's authority to those powers expressly conferred. ${ }^{273}$ Of course, meeting subsidiarity criteria may help to explain why the exercise of otherwise conferred Community authority is a good idea, ${ }^{274}$ but that is less than a decisive commendation-let alone an additional basis of Community power. The distinction was neatly captured by the Amsterdam Protocol, which departed from the Edinburgh Conclusions in observing that subsidiarity "allows Community action within the limits of its powers to be expanded where circumstances so require, and conversely, to be restricted or discontinued where it is no longer justia ed." 275

Even the justiacatory power of subsidiarity, however, may be treacherous. Given the Community obligation to "approximate" or harmonize Member State laws in certain areas, such as in pursuit of the common market, ${ }^{276}$ suggestions that Community action is pref-

Some Re $e^{\circ}$ ections on the Principle of Subsidiarity, in Subsidiarity: The Challenge of Change, supra note 19, at 25-26; see also Emiliou, supra note 235, at 401 (claiming that "centralising tendency" of Article 5 "means that the Communities, in the aeld of concurrent competences, will be required to perform in so far as necessary only those tasks which can be carried out more effectively at the Community level than the national level") (emphasis added). Stephen Weatherill has argued that, consistent with subsidiarity, even the Court's authority may be expanded if the political institutions and Member States fail to respond adequately to the need to ensure product safety. See Stephen Weatherill, Shaping Responsibilities in the Legal Order of the European Community, in Federalism and Responsibility, supra note 238, at 211. Toth further suggests that because subsidiarity may be infringed by Member States taking an action that "falls with exclusive Community competence or within Community aeld of ation," it may also be the subject of an action by the Commission under Article 226 (ex art. 169) or by another Member State under Article 227 (ex art. 170). See Toth, supra note 22, at 276-77. This seems the most doubtful. Even if subsidiarity can be employed to justify Community action, which is doubtful, it is still a further stretch to suggest that it establishes an enforceable preemption doctrine.

271. See Subsidiarity Communication, supra note 243, at 116 ("The principle of course operates in both directions: if, within the a eld of Community competences, a decision or action at Community level meets these requirements, it should be undertaken at this level.").

272. See Edinburgh Conclusions, supra note 242, at 13-14 ("Subsidiarity is a dynamic concept and should be applied in light of the objectives set out in the Treaty. It allows Community action to be expanded where circumstances so require, and conversely, to be estricted or discontinued where it is no longer justi ${ }^{\mathrm{a} e d .}$ ").

273. See EC Treaty art. 5 (ex art. 3b) ("The Community shall act within the limits of the powers conferred upon it by this Treaty and of the objectives assigned to it therein.").

274. See, e.g., Cass, supra note 6, at 1108 \& n.2; Vlad Constantinesco, Who's Afraid of Subsidiarity?, 11 Y.B. Eur. L. 33, 51 (1991). ("[Subsidiarity's] implementation will ful'1 the function rather of legitimating than of delimiting the competences of the Community.").

275. Amsterdam Protocol, supra note 16, at 105-06 II 3; cf. Edinburgh Conclusions, supra note 242 , at $13-14$.

276. See EC Treaty arts. 14 (ex art. 7a, after amendment), 94 (ex art. 100), \& 95 (ex art. 100a, after amendment). 
erable for such a reason may easily be read to require it. This clearly risks compromising subsidiarity. The core of subsidiarity is the right of Member States to diverge, and it would turn that principle on its head to presume too easily that the need to prevent divergence justia es Community intervention. Thus, the possibility that individual governments might not independently opt for the Community-nominated policy_or, put another way, that convergence will not naturally occur - cannot, by itself, warrant Community action, lest subsidiarity protect only the right of each Member State to mimic Brussels. ${ }^{277}$ Subsidiarity may be satis ${ }^{\mathrm{a}} \mathrm{ed}$, and Community action justiaed, only when the unanimity is an indispensable objective of the measure in question, or when other, longer-term interests of Member States as components of the Community are served.

\section{Subsidiarity and Proportionality}

The subsidiarity test is informed by the principle and precedent of proportionality, with which it substantially overlaps. ${ }^{278}$ While subsidiarity generally concerns the propriety of Community action, and proportionality the degree or scope of that action, ${ }^{279}$ the subsidiarity component of Article 5(2) permits Community action only "in so far as" its criteria are met-suggesting application to the scope of action as well. ${ }^{280}$ Reciprocally, Article 5(3)'s principle of proportionality, which certainly applies to matters of scope or degree, also re ${ }^{\circ}$ ects subsidiarity concerns. ${ }^{281}$ Though the proportionality doctrine predated the Maastricht Treaty, and generally permitted individuals to defend their interests against government action, it appears to have been included in Article 5 precisely to safeguard the interests of Member States against disproportionate action by the Community. ${ }^{282}$

277. Put more formally, the mere prospect of dissimilarity, without more, does not "signiacantly damage Member States' interests" within the terms of the Protocol. If nothing else, the trend away from unanimous decision-making must be thought to gainsay any such role for subsidiarity. This is also suggested, if weakly, by the Protocol's recognition of "actions by Member States alone"-in the plural, rather than singular-in addition to "lack of Community action," as alternatives to be compared by Community action. See Amsterdam Protocol, supra note 16, at II 5.

278. This overlap does not, however, suggest redundancy. While subsidiarity is irrelevant to matters within the Community's exclusive competence, proportionality applies regardless of such a restriction. In addition, proportionality's preexisting role in Community jurisprudence means that it is less subject to any reservations imposed by the acquis communautaire.

279. See, e.g., Edinburgh Conclusions, supra note 242, at 13 (Subsidiarity addresses the question "Should the Community act?" while proportionality addresses "What should be the intensity or nature of the Community's action?"); Nicholas Emiliou, The Principle of P1oportio nality in European Law 140 (1996).

280. See Lenaerts, supra note 17, at 849-50.

281. See Amsterdam Protocol, supra note 16, at 105 II 1, 106 IIII 6-7.

282. See Takis Tridimas, The Principle of Proportionality in Community Law: From the Rule of Law to Market Integration, 31 Irish Jurist 83, 99 (1996). 
Consistent with this view, the Amsterdam Protocol presents an integrated view of subsidiarity and proportionality. One of the Protocol's main assertions is that Community legislation is to remain "as simple as possible" and "legislate only to the extent necessary." Moreover, "[o]ther things being equal, directives should be preferred to regulations and framework directives to detailed measures." ${ }^{283}$ By itself, this is a relatively modest restriction: if a framework directive can appropriately be employed, it should, and anything more intrusive should be supported by adequate reasoning. ${ }^{284}$ The Protocol ampliaes this through two relatively straightforward auxiliary principles. First, "[w]hile respecting Community law, care should be taken to respect well established national arrangements and the organisation and working of Member States' legal systems." 285 Second, "[w]here appropriate and subject to the need for proper enforcement, Community measures should provide Member States with alternative ways to achieve the objectives of the measures." 286

These principles, and existing proportionality case law, are highly relevant to assessing the need for Community remedies. Proportionality has been applied to a broad spectrum of issues, including the type and degree of relief afforded by the judiciary. ${ }^{287}$ Indeed, perhaps " $[\mathrm{t}]$ he only cases where the Court appears reluctant to apply the principle is where it is invoked in an attempt to justify a failure to comply with Community law"288 — an exception wholly in keeping with the recurrent strains of concern for self-interest and estoppel in Community remedies law. Of major import, however, is providing a body of precedent ready to adapt to the institutional

283. Amsterdam Protocol, supra note 16 , at 106 II 6

284. See Weatherill, supra note 34 , at 82 .

285. See Amsterdam Protocol, supra note 16, at 106 II 7; see also id. at II 6 ("Directives as provided for in Article 189 of the Treaty, while binding upon each Member State to which they are addressed as to the result to be achieved, shall leave to the national authorities the choice of form and methods.").

286. Id. at 106 II 7 .

287. See Case C-12/95 P, Transacciones Maritimas SA v. Commission, 1995 E.C.R. I-467; [1996] 2 C.M.L.R. 580 (1996) (holding that order conditioning interim suspension of Commission decision withdrawing aid on Company's ability to obtain back guarantee for full amount of aid granted does not infringe principles of effective judicial protection or proportionality); See also Case C-149/9S P(R), Commission v. Atlantic Container Line, 1995 E.C.R. I-2165, [1997] 5 C.M.L.R. 165 (1995) (upholding interim suspension of Commission decision despite objection to scope on proportionality grounds).

288. See Tridimas, supra note 282, at 83-84 \& n.8; e.g., Case 142/87, Belgium v. Commission (Tubemeuse case), 1990 E.C.R. I-959, I 66, [1991] 3 C.M.L.R. 213, II66 (1991) (holding that "recovery of unlawful aid is the logical consequence of the anding that it is unlawful. Consequently, the recovery of State aid unlawfully granted for the purpose of reestablishing the previous existing situation cannot in principle be regarded as disproportionate to the objectives of the Treaty in regard to State aids"). 
setting, including a test for assessing whether Community measures are the least restrictive means of attaining the desired objective. ${ }^{289}$

The Court's initial hesitant forays into Article 5 have captured little of this potential. ${ }^{290}$ One missed opportunity was the Working Time Directive case, ${ }^{291}$ in which the United Kingdom made the potentially appealing argument that the eponymous directive could be "proportionate only if it is consistent with the principle of subsidiarity." 292 Not having the beneat of the Amsterdam Protocol, the Court interpreted subsidiarity as relating solely to whether Community action was necessary, ${ }^{293}$ and suggested that the Council's invocation of a Treaty-based harmonization authority would invariably have satis ${ }^{\mathrm{a} e d}$ that principle. ${ }^{294}$ Proportionality simpliciter was then understood to concern whether the means employed by Community law "are suitable for the purpose of achieving the desired objective and whether they do not go beyond what is necessary to achieve

289. The traditional test for proportionality asks whether the Community or Member State measure in question is reasonably related to its objective; whether the measure is the least restrictive, or least burdensome, means of obtaining the desired objective; and whether the measure's beneats outweigh its costs. Each element of this inquiry, but particularly the arst two, resonates in the text of Article 5(2) and (3). See Bermann, supra note 2, at 386-87; Partan, supra note 22, at 68-69.

As Bermann has observed, however, there are also potential tensions between the traditional proportionality test and subsidiarity. The "least burdensome" action required by proportionality may point to Community action, even though the objective could be achieved at or below the Member State level-thereby suggesting, from a subsidiarity standpoint, that a "disproportionate" remedy would be preferable. See Bermann, supra note 2, at 388-89. The $\operatorname{con}^{\circ}$ ict can only be resolved by preferring one principle over the other; Bermann suggests, ultimately, that the legislative institutions be allowed to choose when to relax one or the other, and the Court defer on such occasions in accord with its deferential standard of review. $I d$. at 389-90. The problem is not so easily shrugged aside for judicial subsidiarity, in which the Court may have to choose for itself. But if Article 5(3) proportionality is understood to focus on the potential burden to Member States, as suggested above, con ${ }^{\circ}$ icts between the principles should be few and far between.

290. Subsidiarity has been invoked in a number of cases, but the Court has managed to avoid it in all but a few. See de Búrca, supra note 21, at 225 \& $n .7$ (citing cases); e.g., Case C-233/94, Germany v. European Parliament (Re. Deposit Guarantee Directive), [1997] 3 C.M.L.R. 1379, II 24 (1997) (noting that Germany was not claiming that directive "infringed the principle of subsidiarity, but only that the Community legislature did not set out the grounds to substantiate the compatibility of its actions with that principle").

291. See Case C-84/94, United Kingdom v. E.U. Council (Re. Working Time Directive), 1996 E.C.R. I-5755, [1996] 3 C.M.L.R. 671 (1996). See generally Piet Van Nuffel, Case Law, Working Time Directive (UK v. Council), 3 Colum. J. Eur. L. 298 (1997).

292. 1996 E.C.R. I-5755, [1996] 3 C.M.L.R. at 718 II 54.

293. See id. at TII 54-55; see also Opinion of Advocate General Léger, [1996] 3 C.M.L.R. at $698-700$, III $125-32$.

294. See United Kingdom v. E.U. Council, 1996 E.C.R. I-5755, [1996] 3 C.M.L.R. at 718 IIII 54-55; see de Búrca, supra note 21, at 223 ("One reading of the judgment is that the Court effectively limited the subsidiarity principle, as a standard for review of the exercise of legislative power, to little more than the requirement of showing an adequate Treaty basis for action."). 
it." 295 Giving "wide discretion" to the Council, the Court found no manifest abuse. 296

The Court's failure to scrutinize the need for harmonization may seem unfortunate, but the issue was not well-framed, ${ }^{297}$ and the Court's deference to the Council's assessment is perfectly understandable. ${ }^{298}$ In any case, the Court took care to note the wide scope for national or private sector derogations or discretion as to each provision contested by the United Kingdom. ${ }^{299}$ And in the guise of deciding the issue of the proper Treaty basis for the directive, the Court conducted what amounted to a proportionality inquiry in concluding that one provision-concerning Sunday rest periodscould not be redeemed even by allowing Member State derogations. ${ }^{300}$ A properly framed question, presented after rati ${ }^{\mathrm{a}}$ cation of the Amsterdam Treaty and its protocols, may cause the Court to entertain a more synthetic approach to Article 5 issues. ${ }^{301}$

\section{B. The Propriety of Judicial Subsidiarity}

The absence to date of any case raising a "pure" subsidiarity isue has permitted the Court of Justice to avoid formally addressing one of subsidiarity's most basic and vexing questions: namely, whether the Court should itself be subject to subsidiarity. ${ }^{302}$

Discussions of subsidiarity almost universally assume that it applies solely to legislation, and that the Court's role, if any, is

295. See United Kingdom v. E.U. Council, 1996 E.C.R. I-5755 at If 57, [1996] 3 C.M.L.R. at II 57.

296. See id. at IIII 58-60.

297. The United Kingdom did not raise a separate subsidiarity claim. See Opinion of Advocate General Léger, [1996] 3 C.M.L.R. at 698-99 II 124 \& n.96. Instead, it argued that the directive was improperly predicated on then Article 118a, which allowed adoption of "min imum requirements" relating to work health and safety-in part because there was not $\mathbf{c}-$ monstrable need for Community intervention - and that Article 118a had to be interpreted in light of subsidiarity. The Court responded that once the Council found that it was necessary to improve worker protection and harmonize worker conditions, "achievement of that objective through the imposition of minimum requirements necessarily presupposes Communitywide action." Id. at 717 n.47; see de Búrca, supra note 21, at 223-24.

298. It is also entirely in keeping with the Court's marginal review of legislative determinations in its existing proportionality case law, to which it defers unless the measure is "manifestly inappropriate." See Tridimas, supra note 282, at 86-87.

299. See 1996 E.C.R. I-5755 at III 60-64, [1996] 3 C.M.L.R. at III 60-64

300. See id. at II 37; see Van Nuffel, supra note 291, at 306-08 (arguing that proportionality, rather than Community competence, was true objection to Sunday rest provision)

301. Although the judgment in Working Time Directive, and the opinion of the Advocate General, suggest that subsidiarity and proportionality apply at separate junctures, they act ually address only the subsidiary question of whether proportionality, as well as subsidiarity, governs the occasions for Community action. See Opinion of Advocate General Léger, [1996] 3 C.M.L.R. at 699 IIII 125-27; see also id. at IIII 54-55 (judgment).

302. See Opinion of Advocate Gereral Léger, 1996 E.C.R. at I-5783 If 124 \& n.58, [1996] 3 C.M.L.R. at 698-99 II $124 \&$ n.96 (noting the absence of subsidiarity as a separate objection). 
$\operatorname{con}^{\mathrm{a}}$ ned to reviewing compliance by the Council and the Commission. ${ }^{303}$ Even that role is uncertain. The drafters of the Treaty gnored Parliament's repeated suggestions that the Court's reviewing function be spelled out. ${ }^{304}$ The European Council's Edinburgh Conclusions subsequently claimed that "interpretation of [subsidiarity], as well as review of compliance with it by the Community institutions, are subject to control by the Court of Justice."'305 Those conclusions, however, are probably not binding, ${ }^{306}$ and recommendation for judicial control was ignored by the Amsterdam Protocolwhich states merely that "[c]ompliance with the principle of subsidiarity shall be reviewed in accordance with the rules laid down by the Treaty. ${ }^{\prime 307}$ In the interim, the Community institutions hammered out an agreement on the application of subsidiarity that $\dot{\mathrm{g}}$ nored the Court altogether. ${ }^{308}$

Despite these developments, as a textual matter, the justiciability of subsidiarity and its application to the Court's own work seem clear. Article 5 says that "the Community" is to act in a manner consistent with subsidiarity. ${ }^{309}$ Article 7 of the Treaty further provides that "[t]he tasks entrusted to the Community shall be carried out by ... institutions" including "a Court of Justice," and that "[e]ach institution shall act within the limits of the powers conferred upon it by this Treaty." 310

Since the Court is one of the institutions bound by the limits of Community law, with the adjudication of cases and the construction of Community law as its "tasks" or "acts," subsidiarity should constrain its decisions to "take action" at the Community level. ${ }^{311}$ The

303. See supra text accompanying note 22 .

304. See Resolution on the Principle of Subsidiarity of July 12, 1990, 1990 O.J. (C 231) 163 at IIII 12, 14; Resolution on the Principle of Subsidiarity of November 21, 1990, 1990 O.J. (C 324) 67 at II B2; see also European Parliament Committee on Institutional Affairs, Interim Report on the Principal of Subsidiarity, Eur. Parl. Doc. A3-163/90 (June 22, 1990); European Parliament Committee on Institutional Affairs, Report on the Principal of Subsidiarity, Eur. Parl. Doc. A3-267/90.

305. Edinburgh Conclusions, supra note 242, at 13.

306. See supra note 259 (describing legal authority of Edinburgh Conclusions).

307. Amsterdam Protocol, supra note 16, at 107 II 13 (stating that "[c]ompliance with the principle of subsidiarity shall be reviewed in accordance with the rules laid down by the Treaty").

308. See Edinburgh Conclusions, supra note 242, § III (addressing procedures and practices to be followed by the Commission and the Council). For example, an interinstitutional declaration on the implementation of subsidiarity was adopted by the Council, the Commission, and the Parliament, without any involvement by the Court. See Interinstitutional Declaration on Democracy, Transparency and Subsidiarity, 10 Bull. Eur. Comm. 118 (1993).

309. EC Treaty art. 5 (ex art. 3b).

310. EC Treaty art. 7 (ex art. 4).

311. Cf. Bermann, supra note 2, at 400 (noting that Court effectively takes action at the Community level and prevents action at the Member State level, and concluding that " $[\mathrm{b}] \mathrm{ut}$ for the fact that the intervention is judicial rather than legislative, and is alleged to ${ }^{\circ} \mathrm{Ow}$ drectly from the Treaty rather than from a grant of authority by the Treaty, the conditions for 
Amsterdam Protocol, accordingly, provides that "each institution shall ensure that the principle of subsidiarity is complied with" when exercising its powers. ${ }^{312}$ Article 5(3), moreover, states a proportionality principle that the Court has abundant experience in applying, without suggesting any basis for distinguishing the Court's role in administering other portions of the article-and, indeed, while stating the principles so that they overlap. It may be $\operatorname{dif}^{a}$ cult to envision anyone enforcing subsidiarity against the Court, ${ }^{313}$ but there is no obvious reason why it should not itself be obligated to do so.

Given the Treaty's language, why has application of subsidiarity to the Court's own work-judicial subsidiarity-garnered so little attention? The answer is implicit in criticisms of the Court's potential role in reviewing compliance by the other institutions. ${ }^{314}$ Even

application of the principle of subsidiarity would seem to be present").

312. See Amsterdam Protocol, supra note 16, at 105 II 1; de Búrca, supra note 21, at 221. In the latest edition of his treatise, Professor Hartley cites this language as supporting the conclusion that the Court is required "to use its judicial powers to ensure that the other inst $\mathrm{i}$ tutions respect the principle [of subsidiarity]," see Hartley, supra note 6, at 112 n.60, but leaves it unclear why the Court should not be required to apply the principle to its own work-just as the other institutions do in the ${ }^{\text {a }}$ rst instance.

313. It is somewhat unclear, in general, how any subsidiarity objection might be raised under the Treaty. Possible avenues include Article 230 (ex art. 173, after amendment) actions for annulment (which can be brought by Member States, dissenting institutions, or individuals capable of satisfying the Court's restrictive tests for standing) and actions for damages under Articles 235 (ex art. 178) and 288 (ex art. 215). See Toth, supra note 259, at 274-76. The Edinburgh Conclusions raised doubts, however, about the ability to raise the issue in national courts or via Article 234 (ex art. 177) referrals from those courts, by commenting that subsidiarity "cannot be regarded as having direct effect." Edinburgh Conclusions, supra note 242 at 14. Compare Toth, supra note 22, at 278-79 (putative absence of direct effect, per Edinburgh Conclusions, would not inhibit ability of individuals to raise subsidiarity in national courts as a constitutional defense to application of legislation) with Bermann, supra note 2, at 390-91 (implying that, were the Edinburgh Conclusions accepted, the absence of direct effect would impair the ability of individuals to raise the issue before national courts).

Some of these avenues apply to judicial subsidiarity only awkwardly. Article 230 (ex art. 173), for example, does not mention the Court among the institutions that may be sued. However, this is not necessarily an insurmountable dif ${ }^{\mathrm{a}}$ culty. The Court insisted, after all, that the European Parliament was subject to suit though it also was not named, see Case 294/83, Parti écologiste "Les Verts" v. Parliament, 1986 E.C.R. 1339, [1987] 2 C.M.L.R. 343 (1986), and likewise insisted that the Parliament be added among those permitted to bring actions under that article, see Case C-70/88, Parliament v. Council, 1990 E.C.R. I-2041, [1991] 1 C.M.L.R. 91 (1991). Both decisions were subsequently re ${ }^{\circ}$ ected in amendments for then Article 173.

The more serious dif ${ }^{\mathrm{a}}$ culty is that suit under Articles 230 (ex art. 173) or 235 (ex art. 178) would involve an action against the Court of Justice in the Court of Justice. That, too, is not necessarily fatal; actions under Articles 232 (ex art. 175) and 288 (ex art. 215), which pose similar problems, have been anticipated. See Herzog \& Smit, supra note 268, at $\S 175.16$ (noting that Court has been a defendant in staff proceedings, and might plausibly bring $\mathrm{x}$ tions as a plaintiff concerning, for example, the failure by other institutions to provide budgetary allocations), 215.06[2] (noting that the Court can be held liable for its own acts).

314. See, e.g., Mackenzie-Stuart, supra note 19, at 40-41 (subsidiarity entirely nonjusticiable); Schaefer, supra note 239, at 691-92 (endorsing political resolution); Toth, supra note 22 , at $280-85$. 
those ${ }^{\text {anding }}$ subsidiarity justiciable would generally con ${ }^{a}$ ne it to determining whether other institutions considered the alternative of Member State action, rather than tasking the Court with the substantive review of whether Community action is justia ed. The reason, it would appear, is not only that the Court owes deference to these other institutions, but also that the Court is not competent to make such determinations. ${ }^{315}$

While such complaints are not terribly common in the Community, the basic contours are familiar. ${ }^{316}$ First, the Court is not wellsuited to exercise the political and policy judgments required to determine which level of government is best suited to achieve a particular objective, and may damage its credibility by even attempting the task. ${ }^{317}$ It may now be so biased toward integration and centralization that it cannot be trusted with such an inquiry. ${ }^{318}$ (In something less than a vigorous denial, the late Judge Mancini and David Keeling once described integration as a "genetic code transmitted to the court by the foundingfathers." $)^{319}$ Second, even if

315. See Bermann, supra note 2, at 390-95 (assuming justiciability, and advocating Court review for "minimal adequacy of a "subsidiarity impact analysis"'); Emiliou, supra note 235, at 402-05 (advocating "marginal review" of subsidiarity under which Community action is reviewed for patent error or misuse of power); P.J.C. Kapteyn, Community Law and the Principle of Subsidiarity, 1991 Revue des Affaires Europeennes 35, 41 (stating that "if the principle of subsidiarity is formulated in such a way that it can be objectivized, then it is amenable to judicial review," but in any event "judicial control will be of a limited kind and only exceptional circumstances can lead to a negative judgment on the measures taken or to be proposed"); J.H.H. Weiler, Journey to an Unknown Destination: A Retrospective and Prospective of the European Court of Justice in the Arena of Political Integration, $31 \mathrm{~J}$. Common Mkt. Stud. 417, 438 (1991) (advocating that the Court consider subsidiarity justiciable, but conduct deferential review). But see de Búrca, supra note 21 (considering, without resolving, broader application); Partan, supra note 22 (arguing for more substantive review).

316. See de Búrca, supra note 21, at 220-21 (noting slow growth in political evaluation of the Court of Justice); $c f$. Hjalte Rasmussen, On Law and Policy in the European Court of Justice 3, 147-48, 152-54 (1986) (describing a virtual conspiracy of silence concerning the Court's doctrinal shortcomings and political vices).

317. Professor Toth, for example, concludes that determining whether the objectives of a Community act could be better achieved at a national level simply "exceeds the proper judicial function." See Toth, supra note 259, at 280-85; see also Bermann, supra note 2, at 401 (acknowledging that, for Court of Justice assessment of its case law under then Article 30 (now 28), "[c]omparing the gains in economic integration with the loss of Member State autonomy is an inescapably dif ${ }^{\mathrm{a}}$ cult and once again deeply political operation"); MackenzieStuart, supra note 19, at 41.

318. See Hartley, supra note 6, at 113 ("Since the essence of subsidiarity is that it protects the rights of Member States against encroachment by Brussels, it is doubtful whether the Court will want to give it any real bite."); Renaud Dehousse, Community Competences: Are there Limits to Growth?, in Europe After Maastricht-An Ever Closer Union 103, 117 (Renaud Dehousse ed., 1994) (arguing that the Court of Justice methodology and subsidiarity are "inspired by diametrically opposed considerations and will be difacult to reconcile"); van Kerbergen \& Verbeek, supra note 235, at 229; see also Dashwood, supra note 34, at 113 (describing integrative tendencies of the Court); Garrett, Keleman \& Schulz, supra note 154, at 155 (same); Stein, supra note 46, at 24-27 (surveying eleven signia cant cases, and concluding that Court of Justice - usually led by the Commission - favored integration in each).

319. Keeling \& Mancini, supra note 178, at 186; see also Mancini, supra note 4, at 612 
the Court were competent and disinterested, it would still lack the democratic accountability desirable for an institution exercising such discretion. ${ }^{320}$

This second objection is less persuasive, particularly concerning judicial subsidiarity. Other Community institutions also suffer from a "democracy de cit," one that may not be curable in the absence of a genuine European polity. ${ }^{321}$ Under the circumstances, entrusting subsidiarity to the Court of Justice may not be so harmful. ${ }^{322}$ True, the doctrine empowers the Court, a non-representative institution, at the expense of institutions serving majoritarian and Member State interests, ${ }^{323}$ but those institutions serve democracy imperfectly. Ju-

(acknowledging "no doubt" as to the activism of the Court in pursuing integration). Judge Mancini was not the only member of the Court to have volunteered that view. See Paul Davies, The European Court of Justice, National Courts, and Member States, in European Community Labour Law: Principles and Perspectives (Liber Amicorum Lord Wedderburn of Charlton) 96 (Paul Davies, ed. 1996) (quoting former Judge's admonition that the greatest in ${ }^{\circ}$ uence on the Court has been "the principle of the progressive integration of Member States in order to attain the objectives of the Treaty'") (quoting H. Kutscher, Modes of Interpretation As Seen by a Judge at the Court of Justice, in Court of Justice of the European Communities, Judicial and Academic Conference (1976)); Constantinos N. Kakouris, Use of the Comparative Method by the Court of Justice of the European Communities, 6 Pace Int'l L. Rev. 267, 273 (1994); see also Fennelly, supra note 72, at 667-68 (citing sources).

320. Thus, after acknowledging the Court's activism, Judge Mancini continued:

Judicial activism, however, is not necessarily a good thing. Judges are usually incompetent as law-makers, and their inventiveness is incompatible with the values of certainty and predictability; it is indeed unfair, since the andings of inventive courts catch

the litigants by surprise. Worse still, .. . courts "are not designed to be a re ${ }^{\circ} \mathrm{ex}$ of a democratic society."

Mancini, supra note 4, at 612 (quoting Thijmen Koopmans, The Roots of Judicial Activism, in Protecting Human Rights: The European Dimension, Studies in Honor of Gérard J. Wiarda 317,321 (1988)). Some defenses of judicial activism are equally familiar. Judges may promote the realization of democratically determined choices by interpreting the Treaty and Community legislation in a manner consistent with its original intent, see Paul Taylor, The Limits of European Integration (1983), may perform a gap- ${ }^{\mathrm{a} l l i n g}$ function, see Geoffrey Garrett, International Cooperation and Institutional Choice: The European Community's Internal Market, 46 Int'l Org. 533, 557-58 (1992), and may protect individual rights that are necessary to secure minority interests, see Anne-Marie Burley, Democracy and Judicial Review in the European Community, 1992 U. Chi. Legal F. 81, 86.

321. Weiler has explored the absence of a Community demos in a number of fascinating articles. See, e.g., Joseph H.H. Weiler, The Transformation of Europe, 100 Yale L.J. 2403 (1991).

322. See Joseph H.H. Weiler, Eurocracy and Distrust, 61 Wash. L. Rev. 1103, 1116-17 (1986) (noting that a "gouvernement des juges" is less troubling than the alternative of a "governement des fonctionnaires"); see also Mary L. Volcansek, The European Court of Justice: Supranational Policy-Making, 15 W. Eur. Pol. 109, 117-19 (1992).

323. See, e.g., Jean Paul Jacqué \& Joseph H.H. Weiler, On the Road to European UnionA New Judicial Architecture: An Agenda for the Intergovernmental Conference, 27 Common Mkt. L. Rev. 185, 204 (1990) ("It is particularly troubling if a majority of Member States, or even all Member States . . . decide that something does comply with the principle of subsidiarity, for the Court to overturn such a decision.”); see also Centre for Economic Policy Research, supra note 235, at 16 (contrasting judicial review with use of Article 235. The Council, the body responsible for adopting Community legislation by majority vote or unanimity, can claim a certain democratic legitimacy by virtue of the fact that its members "represent democratically elected governments in Member States." See Weatherill, supra note 40, at 71; 
dicial enforcement of subsidiarity against them may promote decentralization and, in so doing, democratic values as well. ${ }^{324}$ Indeed, the push by Member States and their regions to incorporate subsidiarity in the Treaty is an extraordinary recognition that the political safeguards of the Community system simply do not work - and that judicial supervision may be necessary in order to achieve the democratic bene ${ }^{a}$ ts of decentralization. ${ }^{325}$

In any event, insisting that the Court review its own handiwork for consistency with subsidiarity should not be so troubling. Unlike legislative subsidiarity, judicial subsidiarity would not itself call into question the laws enacted by other Community institutionsfor example, their speciacation of remedies in a directive. ${ }^{326}$ However, if the Court is to review compliance by the other institutions with subsidiarity, as many advocate, judicial subsidiarity has an additional warrant: the need for consistency. It would be anomalous for the Community institutions to be constrained by subsidiarity in framing legislation, only for the Court to freely construe the legislation, and craft and apply supplementary general principles of law, without any further regard for the principle. ${ }^{327}$ Such a discrepancy would not only undermine the Court's credibility in enforcing legislative subsidiarityvindicating Jacques Delors' warning that "subsidiarity is unfortunately a principle which one applies to others and not to oneself"328_-but promote an anti-democratic result in the name of judicial restraint. ${ }^{329}$

cf. Burley, supra note 320, at 86 (observing that institutional reforms diminishing Member State autonomy may actually worsen democratic de $\mathrm{de}^{\mathrm{a}} \mathrm{it}$ ).

324. See supra text accompanying notes 261-262.

325. See Bermann, supra note 2, at 395-99. As Bermann explains, the Member State's representatives in Council may favor a Community policy even if it could be accomplished by action taken below at the Member State level.

326. Such determinations, however, might be reviewed by the Court pursuant to its task of overseeing legislative subsidiarity; the propriety of that task, and its limits, are beyond the scope of this Article, but are well-addressed elsewhere. See, e.g., Bermann, supra note 2. It may also be appropriate to interpret directives in a fashion consistent with the subsidiarity principle, just as Marleasing imposes a duty on courts to interpret national law consistent with directives.

327. Cf. Bermann, supra note 2, at 400-01 (urging Court of Justice to consider judicial subsidiary). The Edinburgh Conclusions speciacally state that the principle of subsidiarity does not alter the balance between Community institutions. See Edinburgh Conclusions, supra note 242 , at 13 .

328. See Jacques Delors, The Principle of Subsidiarity: Contribution to the Debate, in Subsidiarity: The Challenge of Change, supra note 19, at 10.

329. The theory that subsidiarity promotes democratic accountability-along with all its vices - should apply to the Court. If the Court of Justice is politically constrained, it is by the governments of the most powerful Member States, not the citizens of those states. See, e.g., Garrett, supra note 320, at 558-59 (arguing that Court of Justice serves interests of France and Germany); Garrett, Kelemen, \& Schulz, supra note 154 (elaborating "political power" model). If the Court instead leaves national governments and their courts to fashion their own judicial policies, they are constrained by local polities in which individuals are likely to have more in ${ }^{\circ} u e n c e$. Enhancing political control over the judiciary is problematic, but so is local 
The more troubling objections concern the compatibility of subsidiarity with the judicial function. As with any rule of construction, judicial subsidiarity could in ${ }^{\circ}$ uence, and perhaps alter, the Court's best reading of the law. Faced with an uncertain construction of the Treaty, Community legislation, or judicially established general principles, the Court might, in following subsidiarity, reach different results than it otherwise would, and be lead to them by a mode of analysis in which courts may not be competent. 330

This objection is scarcely unique to subsidiarity, however, and should not be overemphasized. As to legislative subsidiarity, it is no easy feat to explain why reviewing legislation on this basis is less manageable, say, than reviewing the same legislation to see if it unjustiably encroaches on a fundamental right-except of course that rights are traditionally in the courts' bailiwick. ${ }^{331}$ It is still harder to conceive of a distinction between judicial subsidiarity and the felt judicial necessity of principles like supremacy and direct effect, or the apparent dispensability of horizontal direct effect.

This sort of judicial policy analysis is in fact relatively ordinary in the Court of Justice: the Court commonly employs policy or iented, "teleological" and "purposive" reasoning, often in pursuit of integration and not infrequently at the expense of other potentially valid readings. ${ }^{332}$ This has been criticized as unacceptable activism, but also defended as consistent with the Treaty's (and the Community's) underlying purpose. ${ }^{33}$ The important point for immediate purposes, though, is not just that the Court acts in this way, but that

political control of every variety — and yet the Community perceives it to be desirable.

330. It is this problem that most disturbs de Búrca, who nonetheless concludes that judicial subsidiarity probably would not pull the Court into forbidden legislative terrain. See de Búrca, supra note 21, at 221, 229-30. For an American expression of similar concerns, resolved in a different way, see Antonin Scalia, Common-Law Courts in a Civil-Law System: The Role of United States Federal Courts in Interpreting the Constitution and Laws, in A Matter of Interpretation: Federal Courts and the Law 27-29 (Amy Gutman ed., 1997). See also Alexander Bickel, The Supreme Court and the Idea of Progress (1970) (describing atempts by Warren Court to shape U.S. Constitution in accord with estimate of future appreciation of progress as largely failures); John Hart Ely, Democracy and Distrust: A Theory of Judicial Review chs. 1-3 (1980) (critiquing interpretivism and its alternatives).

331. See Bermann, supra note 2, at 394.

332. See, e.g. Kakouris, supra note 319, at 274 (In applying the comparative method, "the Court sometimes dismisses the rule of the common denominator and accepts the rule most conducive to the ultimate objective of Community integration."); Opinion of Advocate General Mancini, Case 294/83, Parti écologiste "Les Verts" v. Parliament, 1986 E.C.R. 1339, [1987] 2 C.M.L.R. 343 (1987) ("Whenever required in the interest of judicial protection, the Court is prepared to correct or complete rules which limit its powers in the name of the principle which deanes its mission.").

333. For a recent exchange, compare Trevor C. Hartley, The European Court, Judicial Objectivity and the Constitution of the European Community, 112 L.Q. Rev. 95 (1996) (decrying activism), with Anthony Arnull, The European Court and Judicial Objectivity: A Reply to Professor Hartley, 112 L.Q. Rev. 411 (1996) (defending Court of Justice performance), and Takis Tridimas, The Court of Justice and Judicial Activism, 21 Eur. L. Rev. 199 (1996) (same). 
it sometimes does not. Subsidiarity-like determinations have also permeated the Court's practice, such as in its preference for rational adjudication of concurrent damages claims against Member States and the Community, ${ }^{334}$ proportionality, ${ }^{335}$ and the newly besieged principle of deference to national remedies. ${ }^{336}$ Subsidiarity, then, should scarcely be regarded as unorthodox, either methodologically or in result. Article 5's contribution lies in making this inquiry incumbent upon the Court, rather than elected (and dismissed) at its whim, and stating a set of principles that is more transparent and objective than the Court's previous enterprises.

Whether these advantages can be realized ultimately depends on whether the Court can be persuaded to try. The most dif ${ }^{a}$ cult task in identifying the occasions on which subsidiarity is to be applied. If Community law requires a particular judicial rule-that is, expressly requires, rather than requires implicitly due to structural, functional, or teleological considerations-there is no scope for

334. See Francette Fines, A General Analytical Perspective on Community Liability, in The Action for Damages in Community Law 19-21 (Ton Heukels \& Alison McDonnell eds., 1997) ("[T]he European Courts only accepts [sic] competence to hear cases when there is no possibility before the national courts to grant a remedy to the applicant. They only accept actions for compensation which cannot be heard usefully by national courts, either because the domestic remedies are inoperative, or because they are nonexistent. Just as Article 3B EC regulates between the national and the Community levels, on the basis of the ef ${ }^{\mathrm{a}}$ ciency of the actions undertaken, so subsidiarity in liability cases operates a regulation of the ${ }^{\circ}$ ow of disputes between the national and the Community courts, based on the effectiveness of the remedies."); see also Wouter Wils, Concurrent Liability of the Community and a Member State, 17 Eur. L. Rev. 191, 198-206 (1992) (reviewing case law).

335. See Steiner, supra note 247 , at 51 . Toth disputes the precedential value of proportionality on the grounds that unlike subsidiarity, it has nothing to do with the allocation of competence between the Community and Member States, and because proportionality applies to the entire Treaty, not just to matters within the Community's exclusive competence. See Toth, supra note 235, at 1083; see also Emiliou, supra note 235, at 401-02 (noting that traditional principle of proportionality was "applicable to the relationship between the Community and its citizens," while subsidiarity "constitutes a limitation of Community powers towards Member States"). As noted previously, though, both subsidiarity and proportionality concern

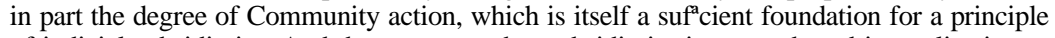
of judicial subsidiarity. And the argument that subsidiarity is not so broad in application as proportionality does not deny that the common elements are part of the acquis. Finally, while the two doctrines indeed have different orientations, the difference is not so categorical as this would suggest; not only is there a potential connection between preserving individual rights and decentralization, but the Court showed additional forbearance- if not deferencein applying proportionality to matters within the purview of national law. See Gráinne de Búrca, The Principle of Proportionality in EC Law, 13 Y.B. Eur. L. 105, 112 (1993) (noting "'federalism dimension" of proportionality case law, according to which "[w]here the measure is seen to be primarily within the competence of the [Member] State, the Court is likely to be reluctant, unless a very important Community interest is adversely affected, to examine the proportionality of the national measure too closely").

336. As Advocate General Jacobs noted in passing, overlooking the need to defer to mtional remedies "could be regarded as infringing the principle of proportionality and, in a broad sense, the principle of subsidiarity, which re ects precisely the balance which the Court has sought to attain in this area for many years." Opinion of Advocate General Jacobs, Joined Cases C-430 \& C-431/93, van Schijndel, 1995 E.C.R. I-4705, II 27, [1996] 1 C.M.L.R. 801, 812 (1996) (emphasis added). 
judicial subsidiarity. ${ }^{337}$ In such circumstances, the supremacy of Community law requires that Community law be applied at the expense of any con ${ }^{\circ}$ icting national law or interests. It would exceed the judicial function and violate the separation of powers for the judiciary to employ its own judicial norms to revise the content of Community law otherwise complying with the Treaty. From the judicial perspective, such law de anes the areas of exclusive Community competence to which judicial subsidiarity is not to apply. ${ }^{338}$

Conceding that, however, highlights the central dif ${ }^{\mathrm{a}}$ culty of applying judicial subsidiarity. It is one thing to acknowledge, as members of the Court have, that it occasionally exercises discretion in interpreting the Treaty. ${ }^{339}$ But judicial subsidiarity requires that the Court authoritatively distinguish between those aspects of its decisions explicitly required by Community law and those that are merely discretionary, which is much the same as asking it to announce when it is engaged in law applying and when in lawmaking. Whether or not this would improve transparency and the Court's performance, ${ }^{340}$ the Court will be sorely tempted to obfuscate, especially in those cases in which it is exercising the greatest degree of discretion.

This is a powerful objection, but applies to virtually any doctrine entailing judicial restraint, at least for courts of last resort. It may also underestimate the degree to which judicial subsidiarity can be internalized. To be sure, if the Court is convinced that a particular result is necessary, whether because of the Treaty's terms or otherwise, subsidiarity may indeed have little purchase. But should the Court be convinced of its obligation to apply judicial subsidiarity, that principle will equip the Court with an additional and legitimate basis for resisting arguments for a Community law outcome. Over time, the principle may become a part of the Court's institutional practice. It should, in any event, serve as the basis by which others within the legal community can critically evaluate the Court's performance. Indeed, the Court's structure places an independent and

337. See Amsterdam Protocol, supra note 16, II 3, at 105 ("The principle of subsidiarity does not call into question the powers conferred on the Court of Justice by the Treaty, as interpreted by the Court of Justice."); $c$. id. If 5, at 106 (Community action warranted where "actions by Member States alone or lack of Community action would con ${ }^{\circ}$ ict with the equirements of the Treaty....").

338. See infra text accompanying notes 357-373 (discussing exclusive competence).

339. See supra text accompanying note 319 ; see also In re Accession by the Community to the European Convention for the Protection of Human Rights and Fundamental Freedoms), 1996 E.C.R. I-1759, II 25, [1996] 2 C.M.L.R. 265, II 25 (1996) ("The Community acts ordinarily on the basis of speciac powers which, as the Court has held, are not necessarily the express consequence of speciac provisions of the Treaty but may also be implied from them."); for a discussion of whether such an acknowledgment is problematic, see de Búrca, supra note 21 , at 229-32.

340. See id. at 232-33. 
in $^{\circ}$ uential voice - the Advocates General-remarkably close at hand. Advocate General opinions, which are circulated in advance of the Court's judgments (and eventually published together with them), typically show greater concern both for transparency and for maintaining the consistency of the Court's precedent, and might in this context serve as the Court's conscience as to the occasionally unwelcome burdens of judicial subsidia rity. ${ }^{341}$

Some of the potential shoals, too, are easily detected. First, in those areas where discretion potentially exists, the Court must avoid con $^{\circ}$ ating legislative subsidiarity with judicial subsidiarity; the Court must avoid conflating the underlying need for a Community policy with identifying and evaluating the judicial objective in establishing auxiliary rules. For example, while Treaty-based harmonization objectives may give rise to a strong presumption favoring Community action, ${ }^{342}$ the mere fact that internal market le gislation aims to improve harmonization does not mean that any judicial remedy crafted to support that legislation must also be harmonized. ${ }^{343}$ Second, the description of the relevant objectives must not unduly preempt the subsidiarity inquiry. An appeal to the need for uniformity, for example, often has great appeal, but its inherent leveling function is in considerable tension with subsidiarity and invites careful and skeptical consideration. ${ }^{344}$ To maintain subsidiarity's presumption against Community action, where the justi ${ }^{\mathrm{a}}$ cation for such action is intrinsically hostile to Member State autonomy, that justi ${ }^{\mathrm{a}}$ cation must withstand searching scrutiny. ${ }^{345}$

State liability should be an ideal proving ground for determining whether these threshold difaculties are surmountable. There is a meaningful and obvious difference between Article 288 (ex art. 215), which expressly requires that the Community be held accountable through non-contractual liability, and Articles 10 (ex art. 5) and 249 (ex art. 189), which might commend that principle. ${ }^{346}$

341. For a general appraisal of the role of the Advocates General, see Bermann et al, supra note 33, at 71-72; Hartley, supra note 6, at 54-56; for examples of the function of opinions, see supra notes 114 (opinions urging adoption of restitutionary remedy in Community law), 197 (opinions arguing in favor of horizontal direct effect after Francovich).

342. See supra text accompanying notes 291-301 (discussing The Working Time Directive Case).

343. Other Community institutions may, however, make that judgment, to which a more deferential standard of review would presumably apply. See, e.g., Council Resolution on the Effective Uniform Application of Community Law and on Penalties Applicable for Breaches of Community Law in the Internal Market, 1995 O.J. (C 188) 1. The Commission, however, has concluded that "Community action cannot be justiaed merely by referring to the objectives of the Treaty and to secondary legislation; the proposal must demonstrate why such action is necessary." Commission of the European Communities, Better Lawmaking 1998: A Shared Responsibility, COM(98)715 anal at 3.

344. See Friedman, supra note 2, at 408-09.

345. See generally Bermann, supra note 2, at 384 .

346. This was reflected in the discussions concerning the propriety of importing Article 
The Court's traditional admixture of respect for national remedial autonomy, on the one hand, and the goal of Community law effectiveness, on the other, should enable it to avoid an embrace of uniformity. Indeed, the autonomy principle, once revived, may provide the Court with a doctrinal vehicle for evaluating the respective advantages of Community and Member State action without formally distinguishing between the Court's interpretive and policy-making functions.

Assuming the Court can determine when a judicial subsidiarity analysis is appropriate, it should be able to develop a meaningful approach. The Amsterdam Protocol has made the basic contours of subsidiarity much less controversial. First and foremost, judicial subsidiarity indicates that a Community remedy is appropriate only where it is necessary to effectuate the underlying obligation, or where a Community rule otherwise promises clear and signiacant bene ${ }^{a}$ ts - especially those of the kind redounding to Member State interests as components of the Community. Second, any diminution in the scope for national decision must be necessary in order to promote those ends. ${ }^{347}$

The Amsterdam Protocol also makes clear that the subsidiarity inquiry is permeated by considerations of proportionality. Care must thus be taken to avoid interfering with "well established mtional arrangements and the organization and working of Member States' legal systems," and, where possible, Member States should be given alternative means to achieve the objectives. ${ }^{348}$ This suggests that embedded legal principles-for example, fee-shifting, or a bar on punitive damages - should be respected, and the opportunity for experimentation with alternatives preserved, unless the case for a contrary Community rule is particularly compelling. In addition, the Court must be especially solicitous of directives. As noted previously, the directive is a privileged vehicle under subsidiarity because it potentially grants considerably greater discretion to

288 (ex art. 215) standards. See, e.g., Opinion of Advocate General Léger, Case C 5/94, Hedley Lomas, 1996 E.C.R. I-2553, II 111, [1996] 2 C.M.L.R. If 111 (1996) ("[T]here is, in my view, a certain illogicality in bringing State liability for breach of Community law into line with the liability provided for in Article 215 of the Treaty, which is itself based on the restrictive liability of the State for its legislative action, provided for under domestic law."). But see Brasserie du Pêcheur, 1996 E.C.R. I-1029 at III 27-30, [1996] 1 C.M.L.R. 889 at 986 (because Article 215 principles are derived from principles common to Member States, they justify principles of Member State liability on the same basis); Opinion of Advocate General Mischo, Cases C-6/90 \& C-9/90, Francovich v. Italy, 1991 E.C.R. I-5395, IIII 70-72, [1993] 2 C.M.L.R. 66, III 70-72 (1991) (advocating, largely for purposes of parity, adoption of Article 215 standards for Member State liability).

347. See EC Treaty art. 5(2),(3) (ex art. 3b); see also supra text accompanying notes 253276.

348. See supra text accompanying notes 284-286. 
Member States. ${ }^{349}$ If the Community's legislative institutions have respected subsidiarity by choosing a directive as the legislative vehicle, the Court ought not obviate their efforts, and its rules should be sensitive to the directive's purposes and limitations.

Judicial subsidiarity seems much more manageable, and more consistent with subsidiarity's values than its alternatives-principally, the nondiscrimination and effectiveness tests. The nondiscrimination principle, though intuitively appealing, was both diff $^{a}$ cult to administer and invasive. The problems of determining the proper analogue between Community law and national law are obvious, ${ }^{350}$ and may explain why the principle was so little used. ${ }^{351}$ The principle's invasiveness is perhaps less obvious. To be sure, national variation is permitted, and Member States are encouraged to follow the distinctive structures of domestic law. But the purpose of requiring them to do so is obscure. There is a persuasive Community interest in discouraging harmful discrimination against the enforcement of Community rights. But discrimination by itselfthat is, the mere failure to treat Community law by the closest proxy of national law - is not necessarily harmful, and national law remedies may yield little information about what is necessary or appropriate for the enforcement of Community law. 352

Imposing the nondiscrimination test, however, surely chills the development of national remedies. In establishing national law, Member State legislatures and courts must be mindful that they set precedent for any comparable Community law that existed or might come to exist. Any Member State choosing to exercise discretion conferred by Community law, therefore, must be cautious in choosing less aggressive remedies, since that effectively sets a ceiling on past and future national law remedies-even if sound political or public policy reasons, perhaps evolving over time, would dictate to the contrary.

The companion principle of effectiveness also did not suf ${ }^{\mathrm{a}} \mathrm{ce}$, as evidenced by the fact that state liability cases considered the issue

349. See supra text accompanying notes 283-284.

350. See Steiner, supra note 109 , at 103 (noting dif ${ }^{a}$ culty in selecting comparable causes of action). The potential breadth of the inquiry was demonstrated by Advocate General Mischo's argument in Francovich that since "it must be possible for every type of action provided by national law" to be used for the enforcement of national law, any Member State providing a right to damages cannot distinguish between public and private defendants. See Opinion of Advocate General Mischo, Cases C-6/90 \& C-9/90, Francovich v. Italy, 1991 E.C.R. I-5357, II 47, [1993] 2 C.M.L.R. 66 (1993). But see Opinion of Advocate General Cosmas, Case C-261/95, Palmisani v. INPS, [1997] 3 C.M.L.R. 1356, IIII 38-40 (1997).

351. See supra text accompanying notes 80-83 (describing limited application of nondiscrimination principle).

352. See Christopher M.G. Himsworth, Things Fall Apart: The Harmonization of Community Judicial Protection Revisited, 22 Eur. L. Rev. 291, 309 (1997). 
only as an afterthought. ${ }^{353}$ That inquiry set too high a bar for Community rules and too unrealistic a standard for judicial deference. The Court required itself, in essence, to let stand national rules that might be demonstrably inferior to a Community alternative, so long as they did not render practice of a Community right "impossible" or nearly so. In practice, however, the Court's attention was drawn to circumstances in which national rules were inherently unlikely to measure up to a Community alternative; when the likelihood of Member State self-interest, and the prospect of those failures, grew intolerably large, the Court was driven to create Community law remedies. ${ }^{354}$ More aggressive approaches to effective judicial protection, however, inspired excesses of an altogether different rature-such as the inquiries into whether national rules protected important procedural interests. ${ }^{355}$ Subsidiarity takes a different tack. Instead of demanding that national rules be justiaed, subsidiarity asks whether a Community rule is necessary to achieve the Community objective, and whether national regimes are systematically unlikely to establish an acceptable rule.

\section{Limits to Subsidiarity's Scope}

Assuming that the Court may (and must) legitimately employ $j$ dicial subsidiarity, two additional principles-Article 5's speciacation that subsidiarity applies only to areas in which the Community lacks "exclusive competence," and the Maastricht Treaty's preservation of the acquis communautaire - may seem to limit its scope. As explained below, however, neither limitation should prove signiacant, largely because of subsidiarity's kinship with proportionality review.

\section{Exclusive Competence}

The notion that the Community has "exclusive competence" over certain areas is a vestige of pre-Maastricht drafting, when it was expected that the Treaty would be revised to divide more de nitively

353. In Francovich, for example, the Court did not claim that the lack of state liability made it impossible to exercise rights granted by Community law, or that the failure of Italy to permit legislative liability for violations of Community law was inconsistent with its treatment of purely domestic claims. But see Opinion of Advocate General Tesauro, Joined Cases C-46/93 \& C-48/93, Brasserie du Pêcheur, 1996 E.C.R. I-1029 at II 13, [1996] 1 C.M.L.R. 889 at II 13.

354. See supra text accompanying note 56 (direct effect as estoppel), and notes 114-117 (rest itution).

355. See Case C-312/93, Peterbroeck, 1995 E.C.R. I-4599, [1996] 1 C.M.L.R. 793 (1995) and Joined Cases C-430 \& C-431/93, van Schijndel, 1995 E.C.R. I-4705, [1996] 1 C.M.L.R. 801 (1995); see supra text accompanying note 209. 
authority between the Community and Member States. ${ }^{356}$ Given that no such division emerged, it is hard to make much sense of the concept, let alone to apply it to subsidiarity. There seems to be three different ways of interpreting exclusive competence:

- The broad view (and hence the narrow view of subsidiarity) ${ }^{a}$ nds exclusive Community competence wherever Community $\mathfrak{a}$ tion is not speciacally restricted, or authority reserved for Member States. In practice, this includes (a) all Community authority under the original EEC Treaty, and (b) those policy areas added subsequently that either relate to that original authority or fail to restrict Community action. ${ }^{357}$

- An intermediate view concludes that the Community's only areas of exclusive competence "are those in which it has already legislated," as opposed to all those in which it has the power to act. ${ }^{358}$ Something like this was advanced by the Commission's Subsidiarity Communication ${ }^{359}$ and in an opinion by Advocate General Léger, ${ }^{360}$ though each is unclear as to whether a potentially exclusive competence also excludes consideration of subsidiarity.

356. See Steiner, supra note 247, at 57; Toth, supra note 239, at 39; Toth, supra note 235, at $1090-91$.

357. Under the original EEC Treaty, it is said, there was no notion of concurrent authority: "where the competence of the Community begins, that of the Member State ends"; see Toth, supra note 239, at 39, entailing exclusive Community competence over all "matters pertaining to the pursuit of common objectives." Id . at 40 . Policy areas added by the Single European Act and the Maastricht Treaty are potentially eligible for subsidiarity analysis, but those matters connected with other areas of exclusive competence (in particular, the internal market) are derivatively immune. See Toth, supra note 239, at 41-43.

358. Steiner, supra note 247 , at 57 (emphasis added).

359. See Subsidiarity Communication, supra note 243, at 121 (describing how Community legislation and case law will actually produce a "block of exclusive power"). At the same time, the communication also describes exclusive competence as "the possibility of depriving Member States of the power to act" (id. at 121) (emphasis added), and claims that within the block of potential action "the subsidiarity principle cannot be invoked to question the advisability of Community action." Id. Compare Steiner, supra note 247, at 58 (regarding Commission as providing inconsistent support for intermediate view), and Steyger, supra note 145, at 68-72 (interpreting communication as requiring exercise of potentially exclusive powers to preclude subsidiarity, and endorsing position), with Toth, supra note 239 , at 40 (arguing that Commission has reached similar conclusion to broad view, "albeit by a different route and for different reasons"). In the end, the Commission contemplates that subsidiarity will not be employed at all in connection with legislation relating to the four freedoms or the internal market. See Subsidiarity Communication, supra note 243, at 120-21; Commission Subsidiarity Report, supra note 240, at 2.

360. Opinion of Advocate General Léger, Case C-233/94, Germany v. European Parliament and E.U. Council (Re. Deposit Guarantee Directive), [1997] 3 C.M.L.R. 1379, III 7090 (1997). The Advocate General argues that the objectives of completing the internal market and achieving harmonization do not "systematically" exclude Member State competence, but where a Treaty provision (then Article 57 EC) describes action by the Community and omits mention of Member States, it will be construed as conferring exclusive competence for purposes of Article 5. Id. TII 80-83. But Member States will retain "complete freedom" to act so long as the Community has not, and may always legislate so long as they do not undermine any Community-harmonized rules. Id. II 85. 
- The narrow view (and hence the broad view of subsidiarity) ands exclusive competence only where Member State authority is curtailed by the relevant Treaty provision. ${ }^{361}$ Contrary to the broad view, this considers objective-oriented competences not to be exclusive, so that "in principle, Community competences of the kind granted in the EEC Treaty"-including the establishment of an internal market- "cannot be considered as exclusive." 362 And contrary to the intermediate view, the narrow view claims that Community action can be always reconsidered and withdrawn, so that areas in which the Community has presently acted need not be considered inherently exclusive in character. ${ }^{363}$

In my view, the narrow view of "exclusive competence" is persuasive. The subsidiarity inquiry makes no sense where the Community is the only level of authority permitted to act. The Member State alternative simply does not merit consideration. ${ }^{364}$ The broad and intermediate views assume, however, that some areas are offlimits merely because of Community action-actual or potential. This is an unpersuasive reading of Article 5. The broad view's asumption that power potentially exercisable by the Community cannot be given back via subsidiarity is largely driven by a concern that doing otherwise would undermine the pursuit of Community objectives, because, in Toth's terms, that "would be a major step backwards in the process of European integration." 365 But the touchstone of subsidiarity is precisely the question of whether possible Community action is appropriate given the objective at hand. 366 The "surprising and far-fetched" appearance of concluding that subsidiarity applies to virtually nothing results from an attempt to resolve the subsidiarity issue before it is even posed. ${ }^{367}$

361. See Lenaerts, supra note 17, at $850 \mathrm{n} .11$; Schilling, supra note 34, at 229-32.

362. Schilling, supra note 34, at 229. New policy areas added by the Single European Act and the Maastricht Treaty would likewise be open to subsidiarity analysis. Id. at 232. Nonetheless, Schilling would consider the competence to establish a common customs tariff (then Article 28), a common commercial policy (then Article 113), and common rules on competition in the framework of the common agricultural policy (then Article 40(2)(a)) to be exclusive. $I d$. at $229-332$.

363. See id. at 220-23, 227-28.

364. See Lenaerts, supra note 17 , at $849-50$ n.11.

365. See Toth, supra note 239, at 40 (arguing that applying subsidiarity in spheres of potential Community action "would be a major step backwards in the process of European integration"). This tendency to prejudge the merits of a subsidiarity analysis is equally apparent in the Commission's analysis, which tries to de ${ }^{a}$ ne exclusive competence by locating areas in which Community action alone is appropriate. See, e.g., Subsidiarity Communication, supra note 243 , at 120 (" $[\mathrm{T}]$ he authors of the Treaty assumed that, in certain areas, the Community was the only appropriate level for taking the action needed to achieve the objectives of the Treaty.") (emphasis added).

366. See Paul Beaumont \& Gordon Moir, The European Communities (Amendment) Act 1993, with the Treaty of Rome (As Amended): Text and Commentary 43-44 (1994).

367. See Toth, supra note 239 , at 40. 
The intermediate view, on the other hand, suggests that the Community can render subsidiarity a nullity by jumping the gun, effectively deciding whether to assign matters to Member States without hewing to subsidiarity's criteria. ${ }^{368}$ This con'ates exclusive competence with preemption-confusing, in other words, the mture of the Community's authority and the effects of its action ${ }^{369}-\mathrm{a}$ problem only compounded by suggestions that Community authority, once exercised, irreversibly designates the relevant area as lying within the Community's exclusive competence. ${ }^{370}$ This view seems to have been rejected by the Amsterdam Protocol, not to mention the practice of the Community institutions, which have begun to review existing legislation on subsidiarity grounds. ${ }^{371}$

In practical terms, the "exclusive competence" inquiry may even be irrelevant in assessing judicial subsidiarity. As previously argued, subsidiarity concerns are also re $^{\circ}$ ected in the proportionality principle of Article 5, which is not excluded from matters within the Community's exclusive competence. ${ }^{372}$ Proportionality questions of degree or scope, moreover, are at the core of the Community law of remedies. Almost invariably, the basic question is whether, given the existence of Community action, Community law should also control the remedies for its breach. If persuasive, this suggests that even on the broadest view of exclusive competence, subsidiarity-viewed through the lens of proportionality-remains to be addressed.

368. The Commission's communication makes clear that the "obligation" of the Commut nity to act within areas of exclusive competence is not exactly that: the Community may elect not to legislate comprehensively, and Member States may act in those areas where Community legislation is not essential or is "no longer essential." Subsidiarity Communication, supra note 243, at 121.

369. See Subsidiarity Communication, supra note 243 , at 121 ("[T] powers to a block of policy measures linked to free movement must not be confused with occupation of the terrain by the legislator. This raises another problem, the problem of primacy.").

370. See Schilling, supra note 34, at 222-23.

371. See Amsterdam Protocol, supra note 16, at 105-06 \& 3 (describing subsidiarity as "allow[ing] Community action ... to be restricted or discontinued where it is no longer justiaed"); Bermann, supra note 2, at 375 \& nn.186-187 (noting apparent consensus that Community institutions should examine existing legislation for compliance). But see Toth, supra note 239 , at $46-47$ (arguing that subsidiarity should not be applied to previously enacted legislation).

372. See EC Treaty art. 5 (ex art. 3b); Edinburgh Conclusions, supra note 242 (proportionality test applies "whether or not the action is within the Community's exclusive competence"); Subsidiarity Communication, supra note 243, at 120 ("As far as intensity is concerned, subsidiarity provides a guarantee that the extent of the action taken will not be out of proportion to the objective pursued, irrespective of whether the powers exercised are exclusive or shared, as stipulated in the third paragraph of Article [5].”). 


\section{The Acquis Communautaire}

Subsidiarity may also be limited by the entire corpus of existing law. The Treaty on European Union counsels that Community $\mathrm{d}-$ jectives are to be pursued "while respecting the principle of subsidiarity," 373 but also while maintaining and building on the acquis communautaire, 374 or "Community patrimony," 375 which could mean anything from the hard core of binding law to the entire product of the European Communities. ${ }^{376}$

Preserving the acquis was an important means of quelling anxiety over the changes made by the Maastricht Treaty to the Community's governmental structure. ${ }^{377}$ But it is also thought to temper the potential impact of subsidiarity and proportionality. The Amsterdam Protocol thus declares that their application must "maintain[ ] in full ... the acquis communautaire and the institutional balance"; leave unaffected "the principles developed by the Court of Justice regarding the relationship between national and Community law"; and take into account Article 6(4)'s edict that the Union should provide itself with the means necessary to "attain its objectives and carry through its policies." ${ }^{778}$ To some, "the preservation of the $a c$ -

373. TEU art. 2 (ex art. B, as amended).

374. Id. (setting as objective "to maintain in full the acquis communautaire and build on it with a view to considering to what extent the policies and forms of cooperation introduced by this Treaty may need to be revised with the aim of ensuring the effectiveness of the mechanisms and the institutions of the Community"); id. art. 3 (ex art. C, as amended) (describing how the Union's institutional framework is to "respect[ ] and build[ ] upon the acquis communautaire").

375. This is perhaps the best nnof $^{a}$ cial translation. See A.G. Toth, 1 Oxford Encyclopaedia of European Community Law 9 (1990); Carlo Curti Gialdino, Some Re ections on the Acquis Communautaire, 32 Common Mkt. L. Rev. 1089, 1089 (1995). The term is left untranslated in the English and several other versions of the Treaty.

376. See Gialdino, supra note 375, at 1098-99; David A.O. Edward \& Robert C. Lane, European Community Law: An Introduction 54 (2d ed. 1995) (acquis said to entail "a presumption that evolution, or 'progression', is in one direction, that at any point in time there can be identia ed a state of the development of the law which embodies essential rights, obligations and remedies and which cannot be reversed") (citing Cases $80 \& 81 / 77$, Société les Commissionnaires Réunis v. Receveur des Douanes, 1978 E.C.R. 927). Compare Toth, supra note 375 , at 9, with Gialdino, supra note 375, at 1089 n.1 (noting that Danish translation means "Community law in force"), and 1097-99 (describing usage as referring to Community case law). Judge Pescatore further distinguished between ordinary and fundamental acquis, with only the latter being immune from change. See Pierre Pescatore, Aspects Judiciares de L'Acquis Communautaire, 17 Revue Trimestrielle de Droit Européen 617, 618 (1991). The Court has also indicated that certain "foundations of the Community," such as the basic function of its courts, cannot be altered, see Opinion 1/91, In re European Economic Area, 1991 E.C.R. I-6079, IIIT 71-72, [1992] 1 C.M.L.R. 245, IIII 71-72 (1991), though the identity of those foundations is hotly disputed. See Gialdino, supra note 375, at 1109-14.

377. See Gialdino, supra note 375, at 1104-06.

378. Amsterdam Protocol, supra note 16, at 105; see also TEU art. 6(4) (ex art. F(4)). The Edinburgh Conclusions would go still further, indicating that subsidiarity "cannot" call into question the indicated powers, and in particular "shall not affect the primacy of Community law." See Edinburgh Conclusions, supra note 242. To the extent that this differs from the Amsterdam Protocol, it is doubtful that it has much persuasive force. 
quis means that subsidiarity is almost meaningless in legal terms." 379 In keeping with that view, an opinion of then Advocate General van Gerven indicated that an elliptical reference to the $a c$ quis in the Maastricht preamble meant that precedent was not open for review on subsid iarity grounds. ${ }^{380}$

This proposition is striking in several regards. First, the legal force of the acquis is unclear. The most explicit invocations of the acquis occur in parts of the Treaty on European Union that are explicitly excluded from the Court's jurisdiction. ${ }^{381}$ Article 48 (ex art. M), the provision cited by Advocate General Gerven, is subject to the Court's jurisdiction, but states in essence that the EC Treaty is not amended save where amended-a questionable basis for constraining Article 5. ${ }^{382}$ Moreover, even if concern for the acquis sets certain basic doctrines off-limits, subsidiarity is still pertinent to newly arising situations not fully determined by existing Community law. Determining what existing law requires and does not require - and, therefore, what must and must not be subject to subsidiarity analysis - is emphatically a question for the Court.

Second, who is to say that subsidiarity is inconsistent with the acquis? Skeptics, including the Court of First Instance, are surely right to say that subsidiarity was not a formal and general principle of Community law prior to Maastricht. ${ }^{383}$ But subsidiarity-like analyses were clearly a part of Community practice. As the Edinburgh Conclusions suggest, subsidiarity is "present in embryonic or implicit form" in some provisions of the pre-Maastricht treaties pertaining to the exercise of Community legislative functions. ${ }^{384} \mathrm{It}$

379. Jo Shaw, European Legal Studies in Crisis? Towards a New Dynamic, 16 Oxford J. Legal Stud. 231, 244 (1996).

380. See Opinion of Advocate General van Gerven, Case C-18/93, Corsica Ferries Italia Srl v. Corpo dei Piloti del Porto di Genova, 1994 E.C.R. I-1783, II 33.

381. See TEU art. 46 (ex art. L) (Treaty provisions relating to powers of the Court and exercise of those powers apply only to certain provisions of the TEU, not including Articles 2,3, or 6(2) (ex art. B,C, and F, after amendment)); see also Case C-167/94R, Juan Carlos Grau Gomis, [1996] 2 C.M.L.R. 129, II 6 (1995) (refusing jurisdiction to interpret Article 2 (ex art. B) in context of Article 234 (ex art. 177) ruling); Opinion of Advocate General Jacobs, Case C-7/93, Bestuur van het Algemeen Burgerlijk Pensioenfonds v. Beune, 1995 E.C.R. I-4471, II 60.

382. See TEU art. 47 (ex art. M).

383. Case T-29/92, Vereniging van Samenwerkende Prijsregelende Organisaties in de Bouwnigjverheid v. Commission, 1995 E.C.R. II-289, II 331 (concluding that prior to the Maastricht Treaty, subsidiarity did not "constitute a general principle of law by reference to which the legality of Community acts should be reviewed."); see also Toth, supra note 235, at 1079 ("[T] he principle of subsidiarity . . . is not only not part of pre-Maastricht Community law but is totally alien and contradicts the logic, structure and wording of the founding Treaties and the jurisprudence of the European Court of Justice.").

384. See Edinburgh Conclusions, supra note 242; see also Subsidiarity Communication, supra note 243, at 116 ("Subsidiarity and its brother principle, proportionality, were not invented at Maastricht. They exist in the legislative and other practices of the Community."); Lynn E. Ramsey, Subsidiarity: Did the Edinburgh Summit Explain Maastricht's 'S' Word?, 
is also present in a variety of judicial doctrines relating to legishtive competence ${ }^{385}$ and, as previously observed, in other doctrines focused more acutely on the judicial function. ${ }^{386}$ Given this constitutional subtext, it is highly doubtful that judicial subsidiarity con'icts with fundamental parts of the acquis, such as by undermining the core relationship between national and Community law. ${ }^{387}$ It could hardly be expected, in any event, that a principle like supremacy would ${ }^{\mathrm{o}}$ unk the test.

All this said, Francovich is certainly a part of the acquis - if only by virtue of the Court's preemptive strike on Maastricht-and state liability thus might be considered immune from a subsidiarity review. If one accepts the notion of judicial subsidiarity, the idea that state liability somehow sneaked in under the wire is unsettling. ${ }^{388}$ Such a result is also not required in order to respect the acquis, which permits examining how the principles like state liability should be elaborated, as well as reconciled with other preMaastricht strands of Community law. As Professor Gialdino explains, the Court's role in guaranteeing the acquis goes hand in hand with its role in "consolidating the Community patrimony, while also acting as a catalyst for new developments in the de $^{\mathrm{a}}$ nition of a concept which is evolutionary by its very nature." 389 Respecting the acquis communautaire, in other words, does not re-

38 J. L. Soc'y Scotland 316, 316 (1993) ("Taken at its broadest, the principle of subsidiarity is implicit in the Treaty of Rome since decision-making at Community level is very much the exception.”). Thus, subsidiarity has been located in EEC Treaty provisions allowing for Member State derogation to preserve national autonomy in fundamental matters (e.g., EC Treaty arts. 30 (ex art. 36 after amendment), 39(3) (ex art. 48(3) after amendment)), see Steiner, supra note 247 , at 50; in the implicit limits on the pursuit of harmonization under Article 94 (ex art. 100), see Herzog \& Smit, supra note 268, § B.02(f) at P-57-58; in the limitation on residual Community powers under Article 308 (ex art. 235) to matters "necessary" to achieve Community objectives, see Steiner, supra note 247, at 50; Jean Paul Jacqué \& Joseph H.H. Weiler, On the Road to European Union - A New Judicial Architecture: An Agenda for the Intergovernmental Conference, 27 Common Mkt. L. Rev. 185, 203 (1990). But see Toth, supra note 235, at 1082 (distinguishing then Article 235 as an independent basis for Community authority); and in the directive, Steiner, supra note 247, at 50-51; Jacqué \& Weiler, supra note 323, at 203; but see Toth, supra note 235, at 1083 (noting that in practice directives constrain Member State discretion).

385. For example, the Cassis de Dijon "rule of reason" doctrine permitting Member States to derogate from Article 28 (ex art. 30, after amendment) under certain conditions. See Steiner, supra note 247 , at 51 .

386. See supra text accompanying notes $333-336$.

387. Certainly one can envision occasional con ${ }^{\circ}$ icts in the legislative context. For example, Member States might defend national law on the ground that con icting Community legislation violated Article 5. See Cass, supra note 6, at 1129-31. Such con ${ }^{\circ}$ icts would be minimized, of course, were subsidiarity con $^{a}$ ned to a procedural review. Thus Bermann denies any intent of using the subsidiarity principle to "entail reopening the doctrines of direct applicability, direct effect, or supremacy." See Bermann, supra note 2, at 402.

388. See supra note 138 (describing history of proposed Maastricht revisions to expressly incorporate damages remedy in Treaty on European Union); infra notes 494-495 (juxtaposing Francovich with incorporation of ${ }^{a}$ nes provision in current Article 228).

389. See Gialdino, supra note 375, at 1099. 
quire - any more than does the principle of subsidiarity itself ${ }^{390}$ that the Court treat its existing case law as a mere artifact. Precisely this spirit is captured by the Treaty on European Union's repeated references to the need to both maintain and build upon the $a c$ quis. ${ }^{391}$ It would be peculiar, indeed, were the acquis to constrain the application of a Treaty-based principle like judicial subsidiarity, even as the Court's less rigid conception of stare decisis permitted it to revise its precedent in accord with other criteria-precisely as occurred in Brasserie du Pêcheur. ${ }^{392}$

For these reasons, the constraint imposed on subsidiarity by the acquis communautaire - a body of law ultimately worth preserving on its merits, more than by virtue of its notional inclusion in the Treaty on European Union and the Amsterdam Protocol-may be overstated. As the next section will show, the gist of postFrancovich case law is in fact compatible with judicial subsidiarity, making it unnecessary to resolve the questions that might be posed in some other context by a pitched con $^{\circ}$ ict between subsidiarity and the acquis.

\section{APPLYING SUBSIDIARITY TO STATE LIABILITY}

As has been noted, while the nondiscrimination and effectiveness principles remained good law, Francovich emerged as an outgrowth of the principle of effective judicial protection. Little in that principle was inherently antagonistic toward subsidiarity. The Court's jurisprudence charged private parties with the task of uncovering and pursuing violations of Community law; the national courts, rather than the Court of Justice or the Commission, were then entrusted to vindicate the rights in question and to enlist the Court of Justice when they deemed it necessary. ${ }^{393}$

390. Article 5 provides that the Community is to act "only if and insofar as the objectives of the proposed action cannot be sufaciently achieved by Member States." See EC Treaty art. 5 (ex art. 3b) (emphasis added). But the Amsterdam Protocol indicates that subsidiarity allows Community action "to be restricted or discontinued where it is no longer justiaed." See Amsterdam Protocol, supra note 16, at II 3 (emphasis added); see also Gialdino, supra note 375, at 1106. As a practical matter, the Commission and Council appear to have already settled on the latter interpretation.

391. See supra note 374 (citing authorities).

392. See supra text accompanying notes 163-167; infra note 491 (describing incorporation of Article 288 (ex art. 215) criteria for liability); cf. Brown \& Kennedy, supra note 72, at 344-47 (describing Court of Justice's somewhat con ${ }^{\circ}$ icting regard for stare decisis); Hartley, supra note 6 , at 75-77.

393. As Weiler explained, writing prior to Francovich, the principle of direct effect alowed "individuals in real cases and controversies (usually against state public authorities)" to be "the principle 'guardians' of the legal integrity of Community law within Europe similar to the way that individuals in the United States have been the principal actors in ensuring the vindication of the Bill of Rights and other federal law." See Weiler, supra note 321, at 2414. 
But Francovich took effective judicial protection to another level, seemingly abandoning direct effect and the need to and any basis for Member State duty in the directives themselves. It is this more comprehensive obligation, emphasizing the vindication of individual rights, that deserves review. As elaborated below, nothing in the rights-based case for state liability warranted bypassing judicial subsidiarity, and the Court's case for a Community standard was at best incomplete.

\section{A. Wrong Turns: Subsidiarity and the Rights-Based Case for State Liability}

\section{Is Subsidiarity Relevant to Rights?}

Francovich rested on the conclusion that " $[\mathrm{t}]$ he full effectiveness of Community rules would be impaired and the protection of the rights which they grant would be weakened if individuals were unable to obtain redress when their rights are infringed by a breach of Community law for which a Member State can be held responsible." 394 The studious passivity of the Court's language makes the basis for Member State responsibility unclear-is it their duty because of their wrong, or because of their ability to make right? ${ }^{395}$ In either event, the Court's underlying rationale may have important consequences for judicial subsidiarity. If Community action is wholly compelled, subsidiarity is irrelevant. Similarly, if state 1ability is based on a deep, constitutional obligation to achieve corrective justice, one so unswerving that any Member State would perforce arrive at it, subsidiarity may not be precluded, but it is at least academic.

For reasons already discussed, it is hard to claim that Francovich was dictated by the Treaty. Those defending the judgment almost invariably resort to larger claims about the Community's purpose, to which subsidiarity is assuredly a counterpoint. Nothing in Article 10 (ex art. 5) suggested that the Court should remove remedial discretion from the national courts. ${ }^{396}$ Prior to either Francovich or

394. Cases C-6/90 \& C-9/90, Francovich v. Italy, 1991 E.C.R. I-5357, II 33, [1993] 2 C.M.L.R. 66, II 33 (1993); see Harlow, supra note 21, at 210; see also supra text accompanying notes $194-196$.

395. See Harlow, supra note 21, at 205-06. After quoting the Court, Professor Hartley translates that "[i]n other words, the principle exists because it is in the interests of the Community that it should exist." See Hartley, supra note 6, at 227.

396. See Case 50/76, Amsterdam Bulb, 1977 E.C.R. 137, 150, [1977] 2 C.M.L.R. 218 (1977). Professor Ward commented that "Article 5 [current art. 10] is the sort of spiritual and essentially vacuous clause that is more commonly found in constitutional orders such as that of Nazi Germany or the Soviet Union," and as such effectively "enable[s] the ECJ to construct any rationale for any decision it likes." Ian Ward, A Critical Introduction to European Law 65 (1996). For a less critical digest of the Court's jurisprudence, see Lang, supra note 
Article 5 (ex art. 3b), the Court's case law indicated that Member States were ordinarily free to determine how best to promote the effectiveness of Community law, save where an independent safeguard needed to be created. Simmenthal, for example, defended the ability of national courts to "decide the Community law issues for themselves"; 397 Francovich preserved only a much more limited freedom to enforce Community law by the state liability standard elected by the Court of Justice. The little precedent suggesting this kind of remedial imperative did so in simpler settings like reimbursement, and without expressly creating an independent Community basis for recovery-relying, in effect, on a jurisprudential consensus among national systems. ${ }^{398}$ There was plainly no such consensus undergirding Francovich. ${ }^{399}$

Francovich may also be read to rest on the argument that state liability is just, and so compelling that Community law cannot tolerate differing national philosophies. ${ }^{400}$ That, too, however, seems untenable. Virtually any obligation to afford individual compensation involves compromise as to when it is to be pursued and when

209.

397. Caranta, supra note 21 , at 705.

398. See, e.g., Case 60/75, Russo v. Azienda di Stato per gli Interventi sul Mercato Agr icola (AIMA), 1976 E.C.R. 45, I[ 9. As Advocate General Jacobs has remarked, "[t]he concept of reimbursement is inherently simpler than that of compensation for damage," not least because it is universally recognized and accommodated by national legal systems. See Opinion of Advocate General Jacobs, Case C-242/95, GT-Link A/S v. Danske Statsbaner DSB, 1997 E.C.R. I-4449, I[ 170, [1997] 5 C.M.L.R. 601, II 170 (1997).

399. Even where legislative liability was imposed, it was almost invariably compromised by conditions stricter than those adopted in Francovich. See, e.g., Opinion of Advocate General Léger, Case C 5/94, Hedley Lomas, 1996 E.C.R. I-2553, [1996] 2 C.M.L.R. 391, II99 (noting that state liability for legislative acts is accepted in Spain, France, Greece, Denmark, Portugal, and the Netherlands, but subject in each case to strict conditions); Opinion of Advocate General Tesauro, Brasserie du Pêcheur, 1996 E.C.R. I-1029 at II 12, [1996] 1 C.M.L.R. at 889, II 12 (acknowledging that while principle of state liability is common to civil law systems, "the tendency has invariably been to limit the scope of liability in various ways"); Waelbroeck, supra note 179, at 320 (observing that "[i]t is well known that the laws of Member States on the liability of public authorities still differ widely"). The Council of Europe's omission of legislative acts from its recommendations on public liability suggests, if anything, that the consensus was against such liability. See Council of Europe, Public Liability: Recommendation No. R (84) 15 Adopted by the Committee of Ministers of the Council of Europe on 18 September 1984 and Explanatory Memorandum 6, If 4 (detailing public acts covered by recommendation), 11-12, If 12 (excluding legislative and quasilegislative acts).

400. Van Gerven notes that full and comprehensive compensation was not explicitly required by Francovich, only "that the right to reparation must be such that the result prescribed by the directive is fully achieved." See van Gerven, supra note 199, at 17; see also van Gerven, Bridging the Gap, supra note 223, at 694-95. There are strong indications, however, that the Court envisioned full compensation for all rights infringed by the failure to achieve those results. See Cases C-6/90 \& C-9/90, Francovich v. Italy, 1991 E.C.R. I-5357, II 37, [1993] 2 C.M.L.R. 66, II 37 (1991) (holding Member States "obliged to make good loss and damage caused to individuals by breaches of Community law for which they can be held responsible"). This objective has been reemphasized by subsequent cases indicating that consequential damages must be available. 
not-just the sort of question judicial subsidiarity can help address. ${ }^{401}$ To begin with, the Court appears to accept that the Community may identify some rights and not others. ${ }^{402}$ The Court also acknowledges political constraints imposed by principles like effective governance, the separation of powers, and federalism. One result, the Court's incorporation of the requirement that breaches be "suf'ciently serious," will certainly leave many injured claimants uncompensated. ${ }^{403}$ At the most abstract level, the Court's concession to the realities of the Community legal system will weed out many potential Francovich claims. Not only does Europe appear to be less litigation-friendly than, say, the United States, ${ }^{404}$ but adding

401. See Christine D. Gray, Judicial Remedies in International Law8 (1987) (noting universal commitment of legal systems to full reparation, but wide variety in method and result, as well as "important qualiacations and exceptions in every legal system"). Indeed, Professor Ball has argued that the European Court of Justice uses rights only to achieve integration, a focus he believes is consistent with the Treaty. See Ball, supra note 72, at 337-45. For sim ilar, but critical, descriptions of the Court's instrumental use of rights, see Jason Coppel \& Aidan O'Neill, The European Court of Justice: Taking Rights Seriously?, 29 Common Mkt L. Rev. 669, 670 (1992); Diarmuid Rosa Phelan, Rights to Life of the Unborn vs. Promotion of Trade in Services: The European Court of Justice and the Normative Shaping of the European Union, 55 Mod. L. Rev. 670, 676-81 (1992); cf. Weiler \& Lockhart, supra note 34; J.H.H. Weiler \& Nicolas J.S. Lockhart, "Taking Rights Seriously": The European Court and Its Fundamental Rights Jurisprudence - Part II, 32 Common Mkt. L. Rev. 579 (1995).

402. See Francovich, 1991 E.C.R. I-5357 at II 40, [1993] 2 C.M.L.R. 66 at II 40 (1991) (requiring, as precondition for liability, that the Community instrument in question "entail the grant of rights to individuals"); see also Barav, Omnipotent Courts, supra note 125, at 289 (noting that Francovich introduces a dichotomy in the category of directives in Community law: "those the purpose or object of which is to create rights for individuals and those which do not").

403. See supra text accompanying note 164 . Other concessions to state autonomy, such as the possibility that Member States might limit the retroactive effect of liability judgments, raise the prospect of further limits. Replying to Germany's entreaty in Brasserie du Pêcheur that the Court consider the ${ }^{a}$ nancial hardship to the government, the Court replied that "[s]ubstantive and procedural conditions laid down by national law on reparation of damage are able to take account of the requirements of the principle of legal certainty," so long as they are not discriminatory and do not render it impossible or excessively dif ${ }^{a}$ cult to obtain recovery. See Brasserie du Pêcheur, 1996 E.C.R. I-1029 at III 97-99, [1996] 1 C.M.L.R. 889 at IIII 97-99. In Francovich itself, however, the Court rejected Advocate General Mischo's suggestion that the holding be prospective only. See Opinion of Advocate General Mischo, Francovich, 1991 E.C.R. at I[ 86, [1993] 2 C.M.L.R. at II 86.

404. It is commonly perceived that Europeans generally pursue judicial redress with something less than the zeal (excessive or otherwise) common in the United States. See, e.g., Alfred W. Cortese, Jr. \& Kathleen L. Blaner, The Anti-Competitive Impact of U.S. Product Liability Laws: Are Foreign Businesses Beating Us at Our Own Game?, 9 J.L. \& Com. 167, 184 (1989); Tsuneo Matsumato, Beyond Compensation, 15 Hawaii L. Rev. 577, 578 (1993); Joan Warner, Guess What? Europe Could Use More Lawsuits, Bus. Wk., Mar. 30, 1998, at 49. Possible reasons include the dif ${ }^{a}$ culty of obtaining effective discovery, the lack of punitive damages, and the relative scarcity of class action and contingency fee arrangements. See Daniela Caruso, The Missing View of the Cathedral: The Private Law Paradigm of European Legal Integration, 3 Eur. L.J. 3, 18-19 (1997) (antitrust claims); see also Richard B. Cappalli \& Claudio Consolo, Class Actions for Continental Europe? A Preliminary Inquiry, 6 Temple Int'l \& Comp. L.J. 217 (1992). An emerging ethic of public interest litigation, however, may make some inroads. See Walter Mattli \& Anne-Marie Slaughter, Revisiting the European Court of Justice, 52 Int'1 Org. 177, at 184, 187-88; see also P.P. Craig, Report on the United 
a Community dimension only further limits the proportion of ptential claimants interested in pursuing reparation. 405

Nor could the rule be bottomed on a more narrowly focused principle of Member State responsibility. The Court's rule presently fails to distinguish between cases in which the state is responsible merely for implementation (and is within its rights to impose the legislation's burden on third parties) and cases in which the state is also responsible under the properly implemented directive. 406 Traditional tort-based notions of responsibility, however, might urge just such a distinction, ${ }^{407}$ particularly so as to permit relief against third parties that both failed to take protective measures and lobbied against implementation. ${ }^{408}$ Indeed, horizontal direct effect might

Kingdom, in The European Courts and National Courts 222-23 (Anne-Marie Slaughter et al. eds., 1998). But see Karen Alter, Explaining National Court Acceptance of European Court Jurisprudence, in The European Courts \& National Courts, supra, at 240 (indicating that "[m]any if not the majority of plaintiffs, lawyers and judges choose not to invoke European legal arguments, even though such arguments would arguably advance their interests"); Ro bert A. Kagan, Should Europe Worry About Adversarial Legalism?, 17 Oxford J. Leg. Stud. 165, 179-83 (1997) (describing European resistance to adversarial legalism).

405. Reference to the Court adds years (and Euros) to the burden of litigation. Unsurprisingly, businesses bring the majority of actions seeking to enforce rights against the Community. See Harlow, supra note 21, at 205 \& n.29 (citing Francette Fines, Etude de la Responsabilité Extra-Contractuelle de la Communauté annex II at 426-49 (1988)); Christopher Harding, Who Goes to Court in Europe? An Analysis of Litigation Against the European Community, 17 Eur. L. Rev. 105 (1992).

406. See Cases C-6/90 \& C-9/90, Francovich v. Italy, 1991 E.C.R. I-5357, [1993] 2 C.M.L.R. 66 (1991) (holding Italy liable for failure to implement directive providing for protection in cases of private insolvency); Cases C-178-179 \& 188-190/94, Dillenkofer v. Germany, 1996 E.C.R. I-4845, [1996] 3 C.M.L.R. 469 (1996) (considering German liability for delayed implementation of packaged tours directive requiring package travel providers to give consumers evidence of security for refunds). The Court's recent decision in Rechberger, which involved Austria's 'owed implementation of the same directive at issue in Dillenkofer, was perhaps the strongest rebuke of a Member State attempt to shift liability. See Case C140/97, Rechberger v. Republic of Austria, 1999 ECJ CELEX LEXIS 1882 (Eur. Ct. Justice, June 15, 1999). One of the alleged failings of Austria's implementing regulation involved its decision to require that only a small proportion of an organizer's potential liability be guaranteed. In addressing Austria's argument that a direct causal link might be lacking if the organizer had acted improperly - or if other exceptional or unforeseeable events had $\propto$ curred - the Court held that the directive imposed an obligation of result, and that any failing by the Member State to attain that result necessarily incurred liability. Id. at III 74-77. Rechberger may be an exceptional case. The Court was able to rely on the fact that the referring national court had already found a direct causal link, permitting it to more easily brush aside the argument of Austria and other Member States that determination of such issues was ${ }^{\mathrm{a}} \mathrm{rst}$ and foremost a matter of national law. Id. at III 70-73. In addition, the decision plainly turned on the Court's construction of the directive at hand. Id. at 9II 70-73. Nevertheless, its reasoning certainly indicates little inclination toward third-party defenses. But see infra text accompanying notes 589-590 (reconsidering possibility of liability shifting).

407. See, e.g., John C. Jeffries, In Praise of the Eleventh Amendment and Section 1983, 84 Va. L. Rev. 47, 71 \& n.91 (1998) (discussing link between requirement of wrongdoing and compensation); Ernest J. Weinrib, The Gains and Losses of Corrective Justice, 77 Iowa L. Rev. 403, 424 (1992) (emphasizing signiacance to corrective justice of defendant's violation of duty that is regarded as wrongdoing, and correlation of that violation to the plaintiff's infringed right).

408. See, e.g., Cases C-178-179 \& C-188-190/94, Dillenkofer v. Germany, 1996 E.C.R. I- 
permit such relief against private third parties, but the Court has declined. ${ }^{409}$ The Community might also be faulted where it elected to proceed by way of directive, but the Court is unlikely to follow that course. ${ }^{410}$ Similar problems, moreover, attend the Court's treatment of plaintiffs: the Court has permitted a limitation on recovery for plaintiffs who failed to avoid damages or pursue available legal remedies, ${ }^{411}$ but seems unlikely to permit comparative negligence or contributory negligence defenses to wholly offset state liability. ${ }^{412}$ These choices may be entirely defensible as a matter of policy, but they scarcely show an unswerving principle that would render irrelevant the type of questions posed by subsid $\mathrm{i}-$ arity.

Finally, national laws should be considered not only as a limiting factor in achieving effective judicial protection, but also as a potentially rich source of alternatives. Member States have employed other mechanisms-including of ${ }^{a}$ cial liability, ${ }^{413}$ administrative

4845, TI[52-54, [1996] 3 C.M.L.R. 469, IIII 52-54 (1996) (rejecting argument by German government that tardy implementation should be excused in part because of domestic opposition by economic interests); $c f$. Burgoin S.A. v. Ministry of Agriculture, Fisheries \& Food, [1986] 1 Q.B. 716 (Eng. C.A.) (suggesting that a government of cial who had revoked a license to import frozen turkeys from France under pressure from U.K. poultry producers might be liable for the tort of misfeasance in public of ${ }^{a}$ ce). But see Kirklees Metropolitan Borough Council v. Wickes Building Supplies Ltd., [1992] 3 W.L.R. 170, 188 (Lord Goff) (observing that since Francovich, "there must now be doubt as to whether the Burgoin case was correctly decided").

409. See supra text accompanying note 197 (noting supporters of horizontal direct effect). But see Steiner, supra note 152, at 9-10 (suggesting that state liability is fairer than direct effect).

410. But see Constantin Stefanou \& Helen Xanthaki, Are National Remedies the Only Way Forward? Widening the Scope of Article 215(2) of the Treaty of Rome, in Remedies for Breach of EC Law, supra note 137, at 85-101 (arguing in favor of concurrent Community and Member State liability).

411. See Opinion of Advocate General Tesauro, Joined Cases C-46/93 \& C-48/93, Bras serie du Pêcheur, 1996 E.C.R. I-1029, III 84, 85, [1996] 1 C.M.L.R. 889, IIII 84, 85 (1996) (acknowledging possibility of considering plaintiff's mitigation and exhaustion of alternative remedies); see also Dillenkofer, 1996 E.C.R. I-4845, I[72, [1996] 3 C.M.L.R. 469, I72 (1996) (same). In Brasserie, Advocate General Tesauro indicated that because an action for damages is essentially ancillary in nature, Member States could permissibly make the right to damages contingent on the claimant's prior pursuit of an action for annulment. See Opinion of Advocate General Tesauro, Brasserie du Pêcheur, 1996 E.C.R. I-1029, IIII 100-04, [1996] 1 C.M.L.R. 921, IIII 100-04 (1996). It is not clear from the opinion whether the Advocate General intended that the claimant's failure to pursue that relief could be made wholly contingent, or used just to reduce damages. In any event, the Court did not advert to this issue in its opinion.

412. However, the possibility of a contributory negligence analysis was expressly recognized by the Council of Europe, which attempted an aggressive rationalization of Member State systems for public liability. See Council of Europe, supra note 399, at 7 ("If the victim has, by his own fault or his failure to use legal remedies, contributed to the damage, the reparation of the damage may be reduced accordingly or disallowed.") (emphasis added). Under certain limited circumstances, at least, a contributory negligence rule may in fact be more ef ${ }^{\mathrm{a}}$ cient.

413. See John Bell, The Law of England and Wales, in Governmental Liability, supra note 139, at 19-20; Gerard Hogan \& Tony Kerr, The Law of Ireland, in Governmental Liability, 
compensation, ${ }^{414}$ and non-judicial advocacy and espousa ${ }^{415}$ —with varying emphases on deterrence and compensation, and each mechanism is capable of ane-tuning. ${ }^{416}$ There may be good cause for resisting these alternatives in their present state, or for certain purposes, ${ }^{417}$ but it seems premature to conclude that a state liability system is the only just method among them.

In sum, any suggestion of a judicial imperative to achieve compensation-one so unswerving as to dispense with the need for a subsidiarity inquiry - relies too much on an institutional sleight-ofhand. Courts confront remedial issues similar to those facing the

supra note 139, at 151; Louis-Paul Suetens, The Law of Belgium, in Governmental Liability, supra note 139, at 183-84, 186; Marie-Aimée de Latournerie, The Law of France, in Governmental Liability, supra note 139, at 201, 204, 213, 224; Marcello Clarich, The Liability of Public Authorities in Italian Law, in Governmental Liability, supra note 139, at 231-36; Wolfgang Rüfner, Basic Elements of German Law on State Liability, in Governmental Liability, supra note 139 , at 250, 252-56, 272.

414. See Anthony W. Bradley \& John Bell, Governmental Liability: A Preliminary Assessment, in Governmental Liability, supra note 139, at 16; John Bell, supra note 403, at 43 (England and Wales); Gerard Hogan \& Tony Kerr, supra note 413, at 179 (Ireland); LouisPaul Suetens, supra note 413, at 194-95 (Belgium). But see P.S. Atiyah, Accidents, Compensation, and the Law 429-31 (3d ed. 1980) (criticizing ad hoc compensation schemes).

415. For example, the of ${ }^{a}$ ce of ombudsperson, existing in some form in Ireland see Gerard Hogan \& Tony Kerr, supra note 413, at 180-81), and France (see Marie-Aimée de Latournerie, supra note 413, at 224-25 (Médiateur)). Cf. Louis-Paul Suetens, supra note 413, at 198 (noting absence of ombudspersons due to broad governmental liability).

416. Ofacial liability can be relatively effective (sometimes overly so) at stigmatizing wrongdoing and forcing of ${ }^{\mathrm{a}}$ cials to internalize costs. See Peter H. Schuck, Suing Government: Citizen Remedies for Of ${ }^{a}$ cial Wrongs 76-77 (1983); William Baxter, Enterprise Liability, Public and Private, 42 Law \& Contemp. Probs. 45, 49 (1978); Lewis Kornhauser, An Economic Analysis of the Choice Between Enterprise and Personal Liability for Accidents, 70 Cal. L. Rev. 1345, 1369-70 (1982); Note, Government Tort Liability, 111 Harv. L. Rev. 2009, 2015-16, 2018 (1998); contrast Jerry Mashaw, Civil Liability of Government Of'cers: Property Rights and Of cial Accountability, 42 Law \& Contemp. Probs. 8, $22-23$ (1978) (suggesting that state liability may inadequately convey incentives to of ${ }^{\mathrm{a}}$ cials). The problem, of course, is that of ${ }^{a}$ cials typically lack the ability to internalize enough costs, but making the government liable for damages not recoverable from the of cial sharply reduces this problem. See Larry Kramer \& Alan O. Sykes, Municipal Liability Under 1983: A Legal and Economic Analysis, 1987 Sup. Ct. Rev. 249, 276-77 \& n.95. An alternate solution, pursued in the United Kingdom, is to make public employers vicariously (but not exclusively) liable for acts taken within the scope of an of cial's authority. See Bell, supra note 413 at 19-20.

417. For example, Brasserie du Pêcheur concluded that it was "inconceivable" that a legislature would commit the requisite abuse of power to satisfy the British tort of misfeasance in of ${ }^{\mathrm{a}}$ ce. See Joined Cases C-46/93 \& C-48/93, Brasserie du Pêcheur, 1996 E.C.R. I-1029, II 73, [1996] 1 C.M.L.R. 889, II 73 (1996). This position was at least vindicated after the fact. See Three Rivers District Council v. Bank of England (No. 3), T Imes (London), Dec. 10, 1998 (Ct. App., judgment of Dec. 4, 1998) (concluding that proof of malice is required).

The more important questions, certainly, are whether the British form of of cial liability could have been adapted, whether in doing so it necessarily would have resembled the Francovich cause of action, and whether such a form was required in all contexts. For the reasons described below in section III(B), understanding state liability as a solution to a cooperation problem lends insight into why a uniform solution may be necessary, at least with respect to non-implementation of directives; state liability, moreover, may be necessary when the problem being redressed involves complementary of ${ }^{a}$ cial conduct at the Community and national levels, rather than conduct that may be isolated to the national level alone. 
Commission or the Council in formulating the underlying directive: in each case, the ability to de $\mathrm{a}^{\mathrm{a} e}$ an objective ought not to dispense with the need to explain why a Community generated solution is preferred, let alone the duty to account for the precise standard selected. Whatever their relative merits, of cial liability and other alternatives deserved consideration. Even if an appropriate result can be achieved only by a Community rule, or can be better achieved by such a rule, the principle of effective judicial protection does not explain why-nor does its reasoning dispense with the need for making the inquiry.

\section{Applying Subsidiarity to Compensation}

The above analysis suggests that Francovich must be evaluated for its consistency with judicial subsidiarity; for many of the same reasons, the argument based on a compensatory imperative does not fare well in subsidiarity terms. Neither the need for uniformity in meting out damages, nor a concern for externalities relating to compensation, are by themselves persuasive.

\section{a. Uniformity}

Uniformity is one of the most frequently cited bases for a Community rule of damages. Allowing national differences in reparation, the argument goes, permits differing results for individuals under similar cicumstances and, thus, fatally undermines the notion of a Community right. ${ }^{418}$ Even proponents of this view, however, concede its political limits. Where legislation is at issue, a decision by the Commission, the Council, and the Parliament to forego uniformity should not be undone by the Court. ${ }^{419}$ Further, when direc-

418. See Joined Cases C-46/93 \& C-48/93, Brasserie du Pêcheur, 1996 E.C.R. I-1029, II 11, [1996] 1 C.M.L.R. 889, II 11 (1996) (“[C]ommon and hence Community conditions" are the "only way of avoiding a situation in which the actual possibility of obtaining reparation for a given infringement is not secured equally in the several Member States and in which discrimination consequently arises as between individuals, which a Community based on the rule of law should not tolerate.").

419. The Community occasionally does specify uniform remedies in legislation, and more frequently proclaims the importance of pursuing uniformity. See, e.g., Council Resolution on the Development of Administrative Cooperation in the Implementation and Enforcement of Community Legislation in the Internal Market, 1994 O.J. (C 179) 1; Fourteenth Annual Report on Monitoring the Application of Community Law (1996), 1997 O.J. (C 332) 1 [hereinafter Fourteenth Annual Report] (citing 1983 declaration by European Parliament that "the uniform, complete and simultaneous application of Community law in all Member States is a fundamental prerequisite for the existence of a Community governed by the rule of law"). However, it is impossible to take the latter exhortations as delegating the authority to pursue uniformity to the Court of Justice. Not only do they often omit any reference to an active role for the Court, but they also indicate due regard "for the principles of Member States' national law, in the light of the subsidiarity and proportionality principles." See Council Resolution on the Uniform Application of Community Law and on the Penalties Applicable for Breaches of 
tives have been chosen as vehicles of legislation, uniformity should be particularly disfavored, as they are purposefully selected to permit variations in implementation ${ }^{420}$ and to permit a variety of harmonization methods. ${ }^{421}$

In the past, the Court's case law has largely accepted similar compromises in its elaboration of constitutional principles. Direct effect, with its abiding failure to specify remedies, and indirect effect, with its recognition that national law may be interpreted to conform with Community law only "as far as possible," 422 acknowledged the potential for national variations. Community law remedies of restitution and interim relief did not profess to reduce it. Other aspects of Community remedies law are positively inimical to uniformity. The non-discrimination principle, for example, means that variation among national rules for national claims is likely to be replicated in the rules for Community law rights, allowing substantial room for diversity within the Community. ${ }^{423}$ Moreover, the over-enforcement of Community law rights-for example, through domestic provisions allowing for punitive damages - is almost certainly permissible, so long as other Community rights are not impaired.

Even if the Court has now reconsidered its approach, any in ${ }^{\circ}$ uence that Francovich may have on uniformity will ultimately be incremental, given the underlying diversity among legal cultures of Member States. Procedural variation, such as statutes and constitutions, may substantially affect results. ${ }^{424}$ Routine differences in kgal environment, such as litigiousness, ${ }^{425}$ delay, ${ }^{426}$ legal assis-

Community Law in the Internal Market, June 29, 1995, 1995 O.J. (C 188) 1; see also Communication from the Commission to the Council and the European Parliament on the Role of Penalties in Implementing Community Internal Market Legislation, COM (95) 162 anal, May 3, 1995 ("Under Community law, implicit referral via straightforward application of Article 5 of the Treaty - or explicit referral to national systems of penalties-is regarded as the norm, whereas de ${ }^{a}$ ning common penalties remains the exception. This general state of affairs is fully in accordance with the subsidiarity principle."). The legislative institutions may, however, respond to prompting by the Court to address the issue of remedies more explicitly in the underlying legislation. See Curtin \& Mortelmans, supra note 30, at $434 \&$ n. 62 .

420. Ehlermann, Opening Speech at the IVth Erenstain Colloquium in Making European Policies Work, supra note 181, at 148.

421. See Piet Jan Slot, Harmonisation, 21 Eur. L. Rev. 378, 382-88 (1996).

422. See Case C-106/89, Marleasing SA v. La Comercial Internacional de Alimentacíon SA, 1990 E.C.R. 4134, [1992] 1 C.M.L.R. 305 (1990).

423. See Himsworth, supra note 352 , at 309 ("[T] his version of an equality principle contributes hardly at all to the process of achieving an acceptable uniformity of rule application where the obstacle in the way of effective and equal enforcement across the Community is the variety of national practice. Quite plainly it is of no bene $e^{\mathrm{a} t}$ at all if the enforcement of E.C. law is allowed to fall to the level which happens to be the domestic level for the time being in each Member State.”).

424. See, e.g., Opinion of Advocate General Jacobs, Case C-430 \& C-431/93, van Schijndel, 1995 E.C.R. I-4705, II45, [1996] 1 C.M.L.R. 801, II 45 (1996).

425. See, e.g., John Henry Merryman, et al., The Civil Law Tradition: Europe, Latin 
tance, ${ }^{427}$ and costs of legal proceedings ${ }^{428}$ induce further disparities. Absent an unlikely attempt to remedy these disparities through Community law, their effect may be to "strike a severe blow at the authority of Francovich." 429

Finally, uniformity might be pursued by less intrusive means. As noted previously, national courts have been inspired, on occasion, to borrow principles developed by the Court of Justice with respect to Community law and Community institutions, ${ }^{430}$ and are regularly encouraged to do so by national judges, academics, and practicing attorneys. ${ }^{431}$ The Maastricht Treaty's provisions relating to judicial cooperation potentially opened up a framework for Member State development of harmonized conditions for state liability. ${ }^{432}$ Finally, the Amsterdam Protocol suggests that directives are the preferred Community mechanism for seeking harmonization, if that end is deemed to be legitimate. ${ }^{433}$ It is by no means obvious that the pursuit of judicial protection through a common Community standard offers much of an improvement over these alternatives, let alone anything that would satisfy the heavy burden appropriate to a subsidiarity sensitive analysis.

America, \& East Asia 599 (1994) (civil case alings in Germany, France, and Italy indicate per-capita ${ }^{a}$ lings among Germans exceed those of French by $50 \%$ and Italians by over $100 \%$ ); Christopher Harding, Who Goes to Court in Europe? An Analysis of Litigation Against the European Community, 17 Eur. L. Rev. 105 (1992) (describing differences based on subject matter, nationality, and "grouping" of litigants); Basil S. Markesinis, Litigation-Mania in England, Germany and the USA: Are We So Very Different? , 49 Cambridge L.J. 233, 247-52 (1990) (noting that German per capita rate of tort suits is approximately three times that of the United Kingdom).

426. For example, delays in the Italian legal system are notorious. See Maria Rosaria Ferrarese, Civil Justice and Judicial Role in Italy, 13 Just. Sys. J. 168 (1988-1989); Oscar G. Chase, Civil Litigation Delays in Italy and the United States, 36 Am. J. Comp. L. 41, 41 (1988).

427. See Alan Paterson, Financing Legal Services: A Comparative Perspective, in The Option of Litigating in Europe ch. 11 (D.L. Carey Miller \& Paul R. Beaumont eds., 1993) (describing substantial differences in the comparative anancing of legal services).

428. Here the French system is exceptional for the low cost and accessibility of litigation, see Daniel Soulez Larivière, Overview of the Problems of French Civil Procedure, 45 Am. J. Comp. L. 737, 738-42 (1997); Richard W. Hulbert, Comment on French Civil Procedure, 45 Am. J. Comp. L. 747, 747 (1997), though these features reflect the expected size of judgments and appears to have an unfortunate effect on the risk of error. See Hulbert, id., at 749 50; Geoffrey P. Miller, The Legal-Economic Analysis of Comparative Civil Procedure, 45 Am. J. Comp. L. 905, 907 (1997).

429. Marcel Storme, Procedural Consequences of a Common Private Law for Europe, in Towards a European Civil Code 90 (Arthur Hartkamp et al. eds., 1998).

430. See Caranta, Learning from Our Neighbours, supra note 227, at 234-38.

431. Id. at $238-44$.

432. See Ernesto Previdi, Making and Enforcing Regulatory Policy in the Single Market, in Participation and Policy-Making in the European Union 84 (Helen Wallace \& Alasdair R. Young eds., 1997).

433. See also Caruso, supra note 404, at 14-15. 


\section{b. Externalities}

States often fail to consider adequately harms that their activities impose on those outside of their boundaries, ${ }^{434}$ thus in ${ }^{\circ}$ icting costs that the affected states a nd hard to recover. ${ }^{435}$ Member States, likewise, may fail to consider adequately costs that non-implementation of Community law imposes on other Member States, ${ }^{436}$ or may design liability rules or compensation schemes that fail to take account of costs imposed on the others. ${ }^{437}$ Such negative externalities are inevitable features of any polity, but a federal system has the opportunity to address centrally those externalities among its members.

As elaborated below, similar arguments are at the core of a persuasive institutional case for state liability. They cannot, however, be fully appreciated within the strictures of the rights-based case for state liability-that is, one focused on correcting imperfections concerning individual compensation. Governments may resist liability claims in general, but the signi ${ }^{a}$ cance of compensation related externalities is highly conjectural; moreover, in the shadow of the non-discrimination principle, national remedies for Community claims have historically hewed closely to those for breaches of mtional law, which by their nature tend to be designed without heed for international claimants. ${ }^{438}$ The continued dif ${ }^{a}$ culty and relative rarity of cross-border claims, Factortame notwithstanding, mean that externalities are unlikely to weigh heavily. Finally, the $\operatorname{dif}^{\mathrm{a}}$ culties obstructing the pursuit of uniformity also suggest that the legal regimes that are most inhospitable to liability claims will continue to impose substantial externalities regardless of any nominal right to compensation. ${ }^{439}$

434. See Shapiro, supra note 2, at 40; Jenna Bednar \& William N. Eskridge Jr., Steadying the Court's "Unsteady Path": A Theory of Judicial Enforcement of Federalism, 68 S. Cal. L. Rev. 1447, 1474 (1995); Friedman, supra note 2, at 407.

435. In some cases, however, downstream states will be able to exercise regulatory power against the actors imposing externalities, thus keeping them in check to some extent. See Roger van den Bergh, The Subsidiarity Principle and the EC Competition Rules: The Costs and Bene ${ }^{a}$ s of Decentralisation, in Constitutional Law and Economics of the European Union 156-59 (Dieter Schmidtchen \& Robert Cooter eds., 1997).

436. See Roger van den Bergh \& Hans-Bernd Schäfer, State Liability for Infringement of the E.C. Treaty: Economic Arguments in Support of a Rule of "Obvious Negligence", 23 Eur. L. Rev. 552, 558 (1998) (according to public choice theory, "[a] national government can ... be assumed to disregard the interests of foreign producers completely").

437. They may not, of course, distinguish among claimants based on their nationality.

438. In addition, European liability rules, particularly those in civil law countries, are stated in broad, categorical terms showing little sensitivity to the prospect of their application in particular cases, let alone to a particular class of claimants. See Pierre Legrand, European Legal Systems Are Not Converging, 45 Int'l \& Comp. L.Q. 52, 67-70 (1996). To my knowledge, however, no research has been done attempting to determine whether the restrictiveness of public liability claims is positively correlated with potential exposure to foreign claims.

439. Cf. Stephen Weatherill, Consumer Policy, in The Evolution of EU Law, supra note 76 , at $693,717-18$ (doubting relevance of damages remedies to cross-border shopping and 
A Community standard for liability will marginally diminish externalities and improve uniformity, just as any federal standard would. But the boundless pursuit of European harmonization is problematic not only because it may not be sound policy, ${ }^{440}$ but also because it unnecessarily places Francovich at odds with subsidiarity. A sounder and more manageable rationale, however, is available at least in the case of state liability. A better case-for these purposes, one more consistent with the subsidiarity principle-can be made for state liability as a means of coercing Member States to cope with both internal and external pressures respecting their duties to implement directives.

\section{B. State Liability and Self-Interest}

Another warrant for state liability-one stressing the instrumental role of liability in deterring Member State misconduct-was implicit in Francovich. ${ }^{441}$ The Court's appealing emphasis on vindicating individual rights, and the political sensitivity of stressing the need to punish Member States, may have muted this argument at the outset. Even though the Court's post-Francovich case law made compensation and effective judicial protection progressively less central-in particular, through the incorporation of Article 288 (ex art. 215) standards ${ }^{442}$ - this gravitation toward standards developed for Community institutions made it increasingly $\operatorname{dif}^{\mathrm{a}}$ cult to regard the Court as oriented toward deterrence of Member States.

The failure of the Court to advance a clear and explicit justiacation for state liability, however, has exposed the Francovich principle to criticism that it is inconsistent with any meaningful objective. The consequent failure to develop a nuanced approach to deterrence, moreover, has given rise to the impression that Francovich is inconsistent with Article 5: requiring Member States to afford "proper" levels of compensation, even for claims relating principally to their own nationals, is patently suspect as a matter of subsidiarity. It also raises a serious theoretical quandary. If Member States are the in ouential actors in the Community, why have they generally tolerated the imposition of liability against them, let alone their encouragement for the Court to persist in denying horizontal direct effect that might instead shift the burden to private parties?

\footnotetext{
indicating that sole solution lies in ability to rely on directives themselves).

440. Cf. Miller, supra note 428, at 916-18 (considering advantages and disadvantages of harmonizing civil procedure).

441. See, e.g., Harlow, supra note 21, at 205; Waelbroeck, supra note 12, at 472; see spra text accompanying notes 193-196.

442. See, e.g., Case C-392/93, Regina v. British Telecommunications, 1996 E.C.R. I-1631, II 40, 2 C.M.L.R. 217, II 40 (1996).
} 
Nevertheless, one can make a plausible case for the consistency of the Francovich principle with subsidiarity-at least with regard to liability for non-implementation of directives - on deterrence grounds. Such a defense requires an institutional, interest-sensitive approach to the objectives of Member States and the means necessary to align their objectives with the public interest. ${ }^{443}$ Put brie $^{\circ} \mathrm{y}$, Member States face collective action problems in implementing directives and punishing non-implementation. As explained below, it should be in Member States' interests to pre-commit to a Community level rule that punishes failures to comply with obligations arising under Article 249 (ex art. 189). By improving the prospects that the court will properly implement directives, such a rule would also advance subsidiarity interests in maintaining the directive as a ${ }^{\circ}$ exible and ef ${ }^{a}$ cacious means of legislating. On the whole, the Francovich principle appears largely consistent with a preexisting and appropriate role for the Court: fashioning Community law remedies under circumstances that indicate a likely failure on the part of Member State, and even Community, institutions.

\section{Cheating in the Community Federal System}

While signi ${ }^{\mathrm{a}}$ cant strides have been made, Member States' longstanding failure to implement Community legislation continues to be widespread and harmful. Member States report adopting a high proportion of the national measures necessary to implement directives, near ninety-six percent by the most recent report. ${ }^{44}$ Aggregate statistics like this, however, tend to conceal the pervasiveness of non-implementation: total noti ${ }^{\mathrm{a}}$ cations not only disguise the proportion of directives that have yet to be fully implemented (i.e., many directives may be lacking one or two notia ${ }^{\text {cations}), ~ b u t ~ a l s o ~}$ fail to show the variance by sector, variability among Member States, and the quality of implementation and enforcement. ${ }^{445}$ The degree to which non-implementation has taxed, and continues to tax

443. In discussing Member State interests, I use public choice, rational choice, and positive political theory interchangeably, subject primarily to the preferences of cited authorities.

444. See Sixteenth Annual Report on Monitoring the Application of Community Law (1998), COM (99) 301 anal, § 1.3 [hereinafter Sixteenth Annual Report].

445. See id. at annex IV. Among single market rules, for example, the Commission recently reported a signia cant decline in what it terms the "fragmentation factor"- the percentage of directives not implemented in one or more Member States-from $35 \%$ to $13.7 \%$ in just over one year. But it noted continued variance among Member States, and described the persistent pattern of delay in transposition as "a serious worry." Id. at $\$ 2.1 .1$; see also Commission of the European Committees, Single Market Scoreboard, No. 4, at 1-2 (June 1999). Certain legislative trouble-spots, like transport, agriculture, public procurement, and environmental regulation, have improved at a substantially slower pace. See Sixteenth Annual Report, supra note 444 , at $\S 1.3$; $i d$. at annex IV, part 1, summary table; Single Market Scoreboard, supra, at 1-2, 4-8. 
the energies, credibility, and success of the Community is hard to overstate. ${ }^{446}$

The Community's implementation woes are unsurprising. The two-stage process contemplated by the directive-adoption at the Community level, followed by implementation by Member States - can easily give rise to collective action problems. States may face a prisoner's dilemma, in which any given state would prefer to avoid implementation while the others follow through with their commitment and provide a regulatory bene ${ }^{\mathrm{a}}$ - $-\mathrm{a}$ somewhat cynical view of the rewards of Community legislation, but not unintelligible in light of the transaction costs attending regulatory reform. ${ }^{447}$ In the face of uncertainty, the best strategy in this situation is non-cooperation. Alternatively, Member States may face an "assurance game" in which the preferred outcome for any given state

446. See, e.g., Report of the Group of Independent Experts on Legislative and Administrative Simpliacation, COM (95) $288^{\text {a }}$ nal/2 at 55 [hereinafter Molitor Report] (concluding that "delays and failures to transpose Community directives into national law, cases of inadequate transposition, and cases of failure to enforce compliance .. . can cause resentment, destroy con $^{\mathrm{a}}$ dence between industry and the regulators, reduce public support for the European institutions, distort competition and impact on jobs"); Kieran Bradley \& Alastair Sutton, European Union and the Rule of Law, in Maastricht and Beyond: Building the European Union 229, 247 (Andrew Duff et al. eds., 1994) (claiming implementation failures, and related failure to attain internal market, contributed to "the most serious crisis of conadence in Community's existence"); see David Anderson, Inadequate Implementation of EEC Directives: A Roadblock on the Way to 1992?, 11 B.C. Int'l \& Comp. L. Rev. 91, 94-97 (1988) (describing "crisis of implementation"); see also Green, supra note 40, at 295-300; Snyder, supra note 31, at 23. Recent reports emphasizing the vigor of implementation efforts only con $^{\mathrm{a}} \mathrm{rm}$ the problem. In 1998 alone, the Commission received over a thousand private-party complaints, and numerous parliamentary inquiries, concerning infringements of Community law by Member States; sent 1,101 Article 169 letters to Member States; issued 675 reasoned opinions, the next step in the Article 169 process; referred over a hundred cases to the Court of Justice; and terminated over 2,000 cases. See Sixteenth Annual Report, supra note 444, at $\S 1.1$. The workload would have been worse, but for the Commission's new self-imposed deadline of one year for considering new cases of infringement, which forced closure of numerous proceedings. See Community Law: European Commission in Crackdown on Offenders in 1996, Eur. Rep., July 23, 1997.

447. See, e.g., Garrett, supra note 320, at 537-38, 557 (assuming that trade-related policies present the prisoner's dilemma). One variable will be the decision rule. Member States outvoted by a qualiaed majority have a clear interest in shirking. Even legislation requiring unanimous approval by the Council may contain abundant incentives. For example, a particular Member State may have gone along solely as a concession in exchange for some other state's cooperation on a different matter. See Adrienne Heritier et al., Ringing the Changes in Europe: Regulatory Competition and the Transformation of the State 17 (1996). A Member State also may favor legislation it knows it will not implement, so long as it believes other states are more likely to adopt and thereby confer a bene ${ }^{a} t$ on defectors.

Another variable will be the legislation's origin. In practice, states proposing Community directives have less reason to renege, if only because the proposals often are made to resemble extant national legislation. See id. at 11-12 (discussing "arst-move" strategy); see also, e.g., Rod Hunter, EU Law Making Needs an Overhaul, Wall St. J. (Eur.), Oct. 11, 1994, at 10 (speculating about efforts by United Kingdom and Germany to in ${ }^{\circ}$ uence content of Community legislation). 
is implementation by all, but the most risk-averse strategy may be non-implementation. ${ }^{448}$

The basic problem is similar in either event. The separation of apparent commitment and implementation, often by several years, encourages states to agree to measures without adequately considering - or, perhaps, even actively disregarding - their willingness to implement. ${ }^{449}$ The resulting implementation failures impair accomplishment of Community legislative goals and undermine con dence in the Community. The most likely failures, moreover, are those measures favoring out-of-state interests, since measures bene ${ }^{a}$ ting local constituencies receive their support and encouragement toward timely and adequate transposition. ${ }^{450}$ The result is a Community legislative system that fails to encourage the very le gislation most properly within its sphere.

Similar problems infect the issue of remedy. Although Francovich tactfully avoided emphasizing the point, governments are often reluctant to afford remedies to those they have injured. It is hardly unusual that some Member States did not permit governmental liability prior to Francovich. Polities are often creative in establishing immunity doctrines for themselves, and slow to offer potential claimants a neutral means of recourse. ${ }^{451}$ Why govern-

448. For representative discussions of these variants, see Jon Elster, Ulysses and the Sirens: Studies in Rationality and Irrationality 19-22 (1984); Mark Irving Lichbach, The Cooperator's Dilemma (1996); and Todd Sandler, Collective Action: Theory and Applications (1992).

449. See, e.g., Green, supra note 40, at 297 ("[T]he Member States when in Council, like Janus, look in two directions: forward to the goals of the Community and backward to their national objectives. Once returned to the national forum, where local pressures increase and the remote and esoteric community aims wane, enthusiasm for the implementation of a drective which, in any event, may represent a compromising of the national interest, naturally recedes."). For internal complaints about this dynamic, see Euro Meetings Branded "A Free Lunch”, Belfast News Letter, October 18, 1997, at 19 (discussing internal complaints about this dynamic); see also Bednar \& Eskridge, supra note 434, at 1474-75 (discussing the same issue in the U.S. context). Nothing in this argument requires overlooking the diverse array of circumstances that might cause a Member State to delay or mishandle implementation. $C f$. Prechal, supra note 43, at 26-29 \& n.41 (discussing rejection of Member State excuses for delayed implementation); id. at 38-39 (discussing rejection of Member State excuses for incorrect implementation). In the absence of effective remedies, however, it is less costly for Member States to overlook these constraints when agreeing to the directive, and such latitude opens the door for strategic behavior.

450. See, e.g., van den Bergh \& Schafer, supra note 436, at 558 (supposing that only the interests of national producers are considered by domestic regulators).

451. In the United States, for example, most states now permit claims against the sovereign just as against private parties, but that is a "relatively recent development." Nevada v. Hall, 440 U.S. 410, 418 n.13 (1979). Some of the most signiacant inroads have been forced upon the states. For example, nearly all states have waived immunity for commercial activ ities, see James E. Pfander, An Intermediate Solution to State Sovereign Immunity: Federal Appellate Court Review of State-Court Judgments After Seminole Tribe, 46 UCLA L. Rev. 161, 205 \& n.166 (1998) (citing cases), but such waivers may be necessary to encourage private parties to conduct business with the government. States also now commonly waive immunity for tax refund suits, but do so in the shadow of alternative jurisdiction in federal 
ments resist liability, and the predicted strength of their resistance, depends on the model of politics employed. Public-spirited of cials may be justiably concerned about making governments riskaverse $^{452}$ or by the sheer budgetary impact of claims. ${ }^{453}$ They may not even perceive government inaction as wrongdoing. ${ }^{454}$ Govern-

district courts. See id. at $173 \& \mathrm{n} .48,205 \& \mathrm{nn} .165,167$. And only a handful of states broadly waived the immunity of local governments before the Supreme Court took that step in Section 1983 actions. See Owen v. City of Independence, 445 U.S. 662, 683 n.27 (1980) (Powell, J., dissenting); see also Schuck, supra note 416, at 207. Of particular relevance here, the only signiacant instance of government liability for legislative conduct remains the liability of municipalities under Section 1983. See Fred L. Morrison, The Liability of Governments for Legislative Acts in the United States of America, 46 Am. J. Comp. L. 531, 540-43 (1998). As for the federal government, the Federal Tort Claims Act, 28 U.S.C. $\$ 2674$ et seq., was enacted only after the administration of relief exhausted Congress' capabilities and patience. See Floyd Shimomura, The History of Claims Against the United States: The Evolution from a Legislative Toward a Judicial Model of Payment, 45 La. L. Rev. 625, 682-83 (1985). The exceptions, including for the execution of policy-related judgments, remain impressive. See 28 U.S.C.A. § 2680(a)-(n). Similarly, prior to the Supreme Court's fashioning of a constit ur tional common law remedy in Bivens, "victims seeking damages for federal Fourth Amendment violations relied almost exclusively on state trespass law." Akhil Amar, Some New World Lessons for the Old World, 58 U. Chi. L. Rev. 483, 500 (1991).

452. See, e.g., Opinion of Advocate General Tesauro, Joined Cases C-46/93 \& C-48/93, Brasserie du Pêcheur, 1996 E.C.R. I-1029, II 12, 1 C.M.L.R. 889, II 12 (1996) ("Admittedly, in the case of the public authorities, precisely because of the nature of the activity which they perform and of the consequences that would ensue were there held to be liability and an obligation to compensate generally, the tendency has invariably been to limit the scope of liability in various ways."); see generally Schuck, supra note 416, at 68-77 (discussing incentive effects of liability on risk of inaction, delay, and changed decision-making).

453. West Germany, for example, apparently considered and rejected an attempt to reconcile its confusing laws concerning governmental liability principally because the a scal burden of expanding liability was too great. See Rüfner, supra note 413, at 272-73; cf. Jacques Algazy, Slap on the Writs, Law Society's Gazette, June 12, 1996, at 18 (noting that expected "avalanche of claims" had not materialized prior to the Court of Justice's early 1996 decisions). Absolute budgetary constraints are now more pressing than ever in light of the stringent guidelines associated with the EMU. Under the Treaty, the Council has the power to compel Member States to refrain from "excessive government de cits" by limiting lending or imposing a nes. See EC Treaty art. 104 (ex art. 104c). If enforceable, such punishments help address the argument that government liability fails to promote deterrence because the go vernment easily can shift losses to the general public. See David S. Cohen, Regulating Regulators: The Legal Environment of the State, 40 U. Toronto L.J. 213, 258-60 (1990). For consideration of the subsidiarity issues involved in the EMU, see Inman \& Rubinfeld, supra note 2; see also Robert P. Inman \& Daniel L. Rubinfeld, The EMU and Fiscal Policy in the New European Community: An Issue for Economic Federalism, 14 Int'l Rev. L. \& Econ. 147 (1994).

Others have hypothesized, however, that bureaucracies may be inclined to grow their budgets, which arguably might incline them toward favoring expenditures in consideration of state liability. See William A. Niskanen, Bureaucracy and Representative Government (1971). But see Terry M. Moe, The Positive Theory of Public Bureaucracy, in Perspectives on Public Choice: A Handbook 459-60 (Dennis C. Mueller ed., 1997) (arguing that Niskanen's theory understates the degree of legislative control over bureaucratic power); Peter Self, Government by the Market 33-34 (1993) (observing that, in practice, bureaucrats are more restrained than Niskanen's theory would predict). Of course, liability-induced budgetary increases may be an exception to Niskanen's supposition that institutional and of ${ }^{a}$ cial self-esteem is positively related to budget size.

454. The government may, for example, disagree with a directive on policy grounds. More understandably, and as evidenced by the excuses often cited for non-implementation, it may 
ment resistance is also consistent with more privatistic goals. Liability claims can be regarded as another form of rent-seeking, ${ }^{455}$ and public choice theory suggests that governments would be disinclined to adopt principles straightjacketing their ability to seek the most favorable bargains for public moneys. ${ }^{456}$

Although courts may check any of these instincts to some extent, ${ }^{457}$ their precedent was generally forged before the problems of interstate coordination became so acute, and when the only legal basis was national law that might be altered by legislative institutions. ${ }^{458}$ At the time Francovich was rendered, therefore, it was

perceive that the real failing lay in political circumstances beyond its immediate control.

455. See generally Robert D. Tollison, Rent Seeking, in Perspectives on Public Choice: A Handbook, supra note 453, ch. 23; Mancur Olson, The Logic of Collective Action (1965); Robert Tollison, Public Choice and Legislation, 74 Va. L. Rev. 339 (1988).

456. There are problems, of course, with attributing rational self-interest to political inst itutions. See, e.g., Edward Rubin, Rational States?, 83 Va. L. Rev. 1433 (1998). Moreover, the comparative advantage of alternatives, like private bills, depends on how well they can be ${ }^{a}$ ne-tuned. For example, the sue-and-be-sued clauses favored for various U.S. federal agencies may afford legislators greater ${ }^{\circ}$ exibility, but in practice, they tend to be somewhat uniform.

457. For example, in France, the Conseil d'Etat reversed course to establish governmental liability on the creative basis of a principle of equality in bearing public burdens égalité devant les charges publiques). See L. Neville Brown \& John S. Bell, French Administrative Law 199-200 (5th ed. 1998) (discussing Société des produits liatiers "La Fleurette," Conseil d'Etat, Jan. 14, 1938); reprinted as Case 58, Les Grands Arrets de la Jurisprudence Administrative (M. Long et al. eds., 9th ed. 1990) (permitting claim for damages brought by manufacturer of artia cial cream following enactment of statutory ban); Duchatalet, Conseil d'Etat, Jan. 11, 1838 (denying claim for damages brought against state by manufacturer of artiacial tobacco following stat utory prohibition).

Other national courts anticipated Francovich. See, e.g., Peter Wytinck, The Application of Community Law in Belgium (1986-1992), 30 Comm. Mkt. L. Rev. 981, 989-91 (1993) (describing 1990 Belgian precedent in which Brussels Court of First Instance ordered injunctive relief and periodic penalty payments against Belgian State for failure to comply with Council Regulation 259/68, albeit while acknowledging possibility of state immunity defenses); Monica Claes \& Bruno De Witte, Report on the Netherlands, in The European Court and National Courts, supra note 404, at 182 (noting thatFrancovich, and the principle of indirect effect before, required no "dramatic" reworking of Dutch law); Fierstra, supra note 156 at $115-16$.

458. As a result, legislative liability usually was highly qualiaed. In France, for example, it was not open to argument that a statutory law was illegal. Plaintiffs seeking to found an action on the principle of equality had to show both an "abnormal" and "special" loss suffered by a limited number of persons and that the challenged national statute or regulation did not expressly preclude compensation. See, e.g., Ministre du Commerce Extérieur c. Société Aliver, Conseil d'Etat, Mar. 23, 1984, Rec., at 128; see also Jacqueline Dutheil de la Bchère, Case Note, 30 Comm. Mkt. L. Rev. 187, 196-97 (1993) (noting that Conseil d'Etat normally concludes that state intervention in economic affairs excludes compensation); Roger Errera, Recent Decisions of the French Conseil d'Etat, 1993 Pub. L. 535, 537 (likening Alivar to the much-maligned Bourgoin S.A. v. Ministry of Agriculture, 1986 Q.B. 716). One review of French government liability law concluded that "[t]he judicial lawmaking in this area seems ... to have been extremely cautious, though not lacking in craftiness," for fear of calling into question previously established public liability doctrine, and permitted liability for legislative acts only under restrictive circumstances. See Latournerie, supra note 413 , at 205,217

Indeed, courts have as frequently played a creative role in erecting doctrines of immunity, thereby creating a precedential hurdle for those judges presently inclined to the contrary. The 
predictable that some Member States would continue to provide inadequate liability. Indeed, absent intervention, Member States anticipating the most dif $^{a}$ culty in implementation were least likely to aggressively penalize failure. ${ }^{459}$

Why, then, should Member States nevertheless look favorably upon the Francovich principle? Clearly, because they value preventing other Member States from reneging, even if they themselves must sacriace freedom of action to achieve that end. In short, cooperation offers distinct advantages over unilateral action. Under the right circumstances, Member States may be willing to be lashed to the mast to restrain themselves from the short-run temptations of breach, at least so long as they can be assured that others will behave likewise. ${ }^{460}$

Reaching credible enforcement agreements, however, is dif ${ }^{\mathrm{a}} \mathrm{cult}$, especially since the problem presupposes a certain lack of trust. ${ }^{461}$ Member States might, then, rely on the Community to help estab-

U.S. and British examples are only most conspicuous. See, e.g., Clarich, supra note 413, at 228-30, 247 (noting evolution of Italian case law from period in which judges creatively recognized various reasons why public liability should not, contrary to the Civil Code, parallel private liability, to a period in which fewer such exceptions were recognized).

459. See Ziller, supra note 181, at 139 . If, as suggested above, compliance is more likely if favored by domestic interests, the potential for state liability will inordinately bene ${ }^{a}$ foreign interests - thereby diminishing prospects for its adoption. Of course, the potential availability of damages may diminish any incentive to press for compliance, but the inef ${ }^{\mathrm{a}}$ ciency of state liability in securing compensation is likely to prevent that from becoming persuasive.

460. States also may prefer the apparent loss of control as a means of warding off pressure from domestic groups. In a similar phenomenon, it has been suggested that Member States may value the ability to hide their support for the original legislation within the dynamic of joint, and secret decision-making. See Stewart, supra note 14, at 50 n.20; Beate Kohler-Koch, Organized Interests in European Integration: The Evolution of a New Type of Governance, in Participation and Policy-Making in the European Union 42, 61 (Helen Wallace \& Alasdair R. Young eds., 1997) (citing R.D. Putnam, Diplomacy and Domestic Politics: The Logic of TwoLevel Games, 42 Int'l Org. 427 (1988)); William S. Peirce, Unanimous Decisions in a Redistributive Context: The Council of Ministers of the European Communities, in The Political Economy of International Organizations: A Public Choice Approach 267, 276 (Roland Va ubel \& Thomas D. Willett eds., 1991).

461. As one commentator noted,

[T] he Member States are not very enthusiastic about strict surveillance and sanctioning of their own market sectors in the interest of Community objectives. The Member States often argue from the standpoint of their own national interests and also from the idea that other Member States are not very strict in carrying out such measures. No Member States likes the idea of a rmly tackling its own national interests, without the guarantee that other Member States are at least as diligent and effective in doing the same ....

These con ${ }^{\mathrm{o}}$ icts of interest thwart enforcement as the ${ }^{\mathrm{a}}$ nal element in the realization of Community objectives.

John A.E. Vervaele, Fraud Against the Community 14-15 (1992), quoted in Christopher Harding, Models of Enforcement: Direct and Delegated Enforcement and the Emergence of a 'Joint Action' Model, in Enforcing European Community Rules: Criminal Proceedings, Administrative Procedures and Harmonization 31 (Christopher Harding \& Bert Swart eds., 1996). Another illustration is provided by the dif ${ }^{a}$ culty Member States have had in reaching agreement on allowing suits against Member States in foreign courts. See Waelbroeck, supra note 12 , at 479 . 
lish and enforce such an agreement. ${ }^{462}$ This reliance has the notable effect of creating a two-way principal-agent relationship: Member States may generally view Community institutions as agents that must be prevented from shirking, ${ }^{463}$ but Community law also 1equires that Member States act as agents for the implementation of Community legislation, and gives them an incentive to vest the Community with some independence of action in enforcing that arrangement. The Court of Justice may have just the right combination of institutional weakness and autonomy to make an effective, yet ultimately faithful, monitor. ${ }^{464}$ If so, the Francovich rule may plausibly serve a deterrence function. ${ }^{465}$

While such an account can explain how Member State interests are served by an effective enforcement scheme, it is an incomplete

462. See generally Lichbach, supra note 448, at 155-204 (discussing hierarchical soltr tions to cooperation games).

463. See, e.g., Mark A. Pollack, Delegation, Agency, and Agenda Setting in the European Community, 51 Int'l Org. 99 (1997). This perception may become more important as procedural reforms increase the independence of Community institutions and confer greater democratic legitimacy upon them. Cf. Koen Lenaerts, Regulating the Regulatory Process: Delegation of Powers in the European Community, 18 Eur. L. Rev. 23, 32-33 (1993) (discussing likelihood that Member States will increasingly exhibit concern over blame-shifting).

464. For an inter-governmental account emphasizing the Court's weakness, and hence its fealty to the interests of the powerful Member States, see Garrett, supra note 320, at 557-59. See also Geoffrey Garrett \& Barry R. Weingast, Ideas, Interests, and Institutions: Constructing the European Community's Internal Market, in Ideas and Foreign Policy: Beliefs, Inst itutions and Political Change 173, 201-02 (Judith Goldstein \& Robert O. Keohane eds., 1993); Garrett, Kelemen \& Schulz, supra note 154; for neo-functional and kindred accounts emphasizing the Court's leading role in developing an essentially autonomous legal system, see Alter, supra note 404, at 234-38; see also Karen J. Alter, The European Court's Political Power, 19 W. Eur. Pol. 458, 461-67 (1996); Burley \& Mattli, supra note 52, at 57-73; Pollack, supra note 463, at 118-21; Alec Stone Sweet \& Thomas L. Brunell, Constructing a Supranational Constitution: Dispute Resolution and Governance in the European Community, 92 Am. Pol. Sci. Rev. 63, 74 (1998); Weiler, supra note 322 (integrationist decisions may evade political supervision by national governments).

The conventional public-choice explanation for the structure of an "independent" judiciary - that disinterested judges are valuable to legislatures because they enhance the value of existing legislative bargains-is also apposite. See William M. Landes \& Richard A. Posner, The Independent Judiciary in an Interest-Group Perspective, 18 J. L. \& Econ. 875 (1975); see also William N. Eskridge \& John Ferejohn, Making the Deal Stick: Enforcing the Original Constitutional Structure of Lawmaking in the Modern Regulatory State, 8 J. L. Econ., \& Org. 165 (1992); John A. Ferejohn \& Barry R. Weingast, Limitation of Statutes: Strategic Statutory Interpretation, 80 Geo. L.J. 565 (1992); John A. Ferejohn \& Barry R. Weingast, A Positive Theory of Statutory Interpretation, 12 Int'l Rev. L. \& Econ. 263 (1992).

465. Eeckhout, supra note 189, at 64; see Lenaerts, supra note 17, at 892; Steiner, supra note 152, at 9 ("the prospect of liability to all parties suffering damage as the result of their failures to implement Community law would provide States with a powerful incentive to comply with their Community obligations"); Martin, supra note 137, at 45 (claiming that liability "will act as a powerful 'encouragement' for the Member States to implement directives accurately and within the prescribed periods") (internal citations omitted). But see Harlow, supra note 21, at 209-10; Frances Snyder, Soft Law and Institutional Practice in the European Community, in The Construction of Europe: Essays in Honour of Emile Noel 45, 50-53 (Stephen Martin ed., 1994) (noting deterrence potential of state liability, but discussing drawbacks). 
measure of whether the state liability rule of Francovich complies with judicial subsidiarity. Short of supposing that the prevailing system of rules must be in accordance with Member States interests because it has not been overturned, it is dif ${ }^{a}$ cult to determine whether a different balance should be struck between their interests in avoiding liability themselves and their desire to use liability to encourage compliance by others. ${ }^{466}$ As the next two sections show, however, there are additional reasons to suppose that the Court's general principles serve the collective interests of Member States, at least in the context of directives.

\section{Maintaining Compliance Through Prescription}

Compliance is not merely an ex post consideration. Whether enforcement is possible, and the potential severity of penalties, surely in uence the ability and willingness of bargaining institutions to reach agreement in the ${ }^{a}$ rst place. ${ }^{467}$ Enforcement prospects also in ${ }^{\circ}$ uence the nature of the agreement and establish the outer bounds of cooperation. A recent study suggested, for example, that states will cooperate only so "deeply" as they reasonably anticipate they can enforce. ${ }^{468}$

466. See, e.g., Garrett, supra note 320, at 557-58 (implying that Member States wish to resolve their prisoner's dilemma); Garrett, Kelemen \& Schulz, supra note 154, at 172-74 (offering positive account of state liability case law); Geoffrey Garrett, The Politics of Legal Integration in the European Union, 49 Int'l Org. 171, 174 (1995) ("If member governments have neither changed nor evaded the European legal system, then from a so-called rational government perspective it must be the case that the existing legal order furthers the interests of national governments."). This account has been subject to powerful criticism. See, e.g., Alter, supra note 404, at 235 (criticizing neo-realist account of judicial behavior); Alter, supra note 22, at 136-40 (using notion of "joint-decision trap" to explain difaculty for Member States of amending Treaty to revise Court of Justice precedent); Pollack, supra note 463,

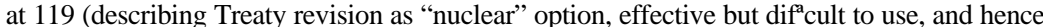
lacking in credibility); cf. Amartya K. Sen, Rational Fools: A Critique of the Behavioral Foundations of Economic Theory, 6 Phil. \& Pub. Aff. 317, 335-36 (1977) (criticizing allinclusive rational actor models). Notably, moreover, Garrett's thesis is that the Court heeds the in uence of only the most powerful states, France and Germany, which may not coincide with the preferences of the other Member States. See, e.g., Garrett, supra note 320, at 55759; cf. Alter, supra note 22, at 140-42 (arguing that the positive account is inconsistent with the failure of the British initiative to limit state liability at the Amsterdam inter-governmental conference). The empirical doubts attending the positive account, and the dif a culty in mapping its results onto a principle that attempts to promote the collective interests of Member States as political components of a federal system, reinforce the appropriateness of the normative focus taken here.

467. If enforcement is impossible, agreement may be pointless and should be negotiated only if its symbolism is especially attractive (and even then, one adds re exively, only if the symbolism outweighs transaction costs). At the other extreme, if enforcement is secure but draconian, and the institutions are unable to ensure their own ability to comply, agreement may be too dangerous. Cf. James D. Fearon, Bargaining, Enforcement, and International Cooperation, 52 Int'l Org. 269 (1998) (suggesting that exogenous factors like the prospect of long-term interaction may improve the prospect of enforcement, but increase incentives to bargain hard, thus decreasing prospects for an agreement in the ${ }^{\mathrm{a}} \mathrm{rst}$ place).

468. See George W. Downs et al., Is the Good News About Compliance Good News about 
A quick glance at the Community, however, suggests a disjuncture between this re ${ }^{a}$ ned measure of cooperation and the frequency and apparent intensity of agreement. Member State implementation problems became more and more pronounced, and the ineffectiveness of the Community legislation program increased, in part because the pace of enacting directives continued unabated. Although there were other reasons for the increased legislation, the paradoxical growth in legislation despite noncompliance may be due in part to the low cost of noncompliance: Member States felt free to accept legislative proposals by the Commission precisely because they knew they would not have to comply. Surveying the gulf between apparent and actual achievements on the environmental front, Richard Stewart observed that "[w]eaknesses in the Community's means of ensuring effective implementation and enforcement of environmental legislation has made it easier for Member States to acquiesce in measures that they would oppose if they were required to achieve prompt and full compliance." 469 Such weaknesses also tempted Member States to resolve their disagreements in the Council by adopting ambiguous or internally inconsistent legislation, leaving it to the Commission or Court to sort out without any real prospect that divergent national interpretations will be penalized. ${ }^{470}$

Compliance dif ${ }^{a}$ culties also help explain why directives became more prescriptive and less useful as an alternative to regulations. Prior to Francovich, the principal means for enforcing the obligation to implement directives lay with the Commission and the direct effect principle. But Commission-led Article 226 (ex art. 169) and, in theory, state-led Article 227 (ex art. 170) proceedings, ${ }^{471}$ were

Cooperation?, 50 Int'l Org. 379 (1996). In theory, depth of cooperation connotes the degree to which an agreement captures the potential collective bene ${ }^{\text {atts }}$ available through perfect cooperation. A more measurable, but imperfect, assessment is the degree to which states are required to depart from the policies they would have pursued in the absence of an agreement. See id. at 383.

469. See Stewart, supra note 14, at 48-49; see also id. at 66; see also Lenaerts, supra note 17, at 853-54; G. Federico Mancini, The Making of a Constitution for Europe, in The New European Community: Decisionmaking and Institutional Change (Robert O. Keohane \& Stanley Hoffman eds., 1991) (prior to Maastricht Treaty, lack of an effective penalty gave "directives a dangerously elastic quality: Italy, Greece, or Belgium may agree to accept the enactment of a directive with which it is uncomfortable knowing that the price to pay for possible failure to transpose it is nonexistent or minimal," necessitating a private enforcement mechanism).

470. See Tom Burns, Better Lawmaking? An Evaluation of Lawmaking in the European Community, in Lawmaking in the European Union 435, 438 (Paul Craig \& Carol Harlow eds., 1998).

471. Article 227 permits a Member State to initiate Court of Justice proceedings against any other state for violating its obligations under the Treaty. Before doing so, the initiating state must bring the matter to the attention of the Commission, which is then obligated to deliver a reasoned opinion after soliciting the views of the other Member States. The Commission's failure to do so, however, is not an impediment to initiating a proceeding before the Court of Justice. 
time consuming and cumbersome, and offered very little hope of compelling Member States to live up to their obligations. ${ }^{472}$ Direct effect, on the other hand, could not always be established, and provided no remedies against private parties left unregulated by a dilatory Member State. A snapshot of the situation in 1990, just prior to Francovich, is illustrative: eighty-three Article 169 and 170 judgments against Member States were outstanding, most of them involving failures to implement Community directives. ${ }^{473}$

In light of these dif ${ }^{a}$ culties, the Community institutions and Member States might rationally increase prescription, and diminish national discretion, in order to facilitate the enforcement of directives. ${ }^{474}$ Prescriptive agreements make the objectives of Community law unmistakable to national administrations and interest groups. ${ }^{475}$

The Member States have proven reluctant to avail themselves of this option; as of 1993 , Member States had brought only two actions under then Article 170, with only one resulting in judgment. See Bermann et al., supra note 33, at 312 (citing Case 141/78, France v. United Kingdom, 1979 E.C.R. 2923); see also Rolf Wägenbauer, How to Improve Compliance with European Community Legislation and the Judgments of the European Court of Justice, 19 Fordham Int'l L.J. 936, 939 (1996) (opining that "Article 170 actions are, for all intents and purposes, a purely theoretical possibility"); P. P. Craig, Once upon a Time in the West: Direct Effect and the Federalization of EEC Law, 12 Oxford J. Leg. Stud. 453, 454 (1992). One reason may be the states' alternative of referring persuasive cases to the Commission's attention: if the Commission is supportive, that may increase chances of achieving settlement. See Bermann et al., supra note 33, at 293, 312. Only the Commission, moreover, may seek penalties under the Article 228(2) (ex art. 171(2)).

472. See, e.g., George A. Bermann, Comment, Europe 1992: Roundup on the Law and Politics of the European Community, 85 Am. Soc'y Int'l L. Proc. 152, 154 (1991) (“"T]he absence of formal sanctions has become such a familiar feature of the EEC legal landscape that it is almost fokloric.").

473. Thirty-three of those judgments involved Italy. See Editorial Comments, How to Strengthen the Effectiveness of Community Law, 28 Common Mkt. L. Rev. 711, 711 (1991); see also Martin, supra note 137, at 35; Wägenbauer, supra note 471, at 940-41 (questioning value of Article 169 and Article 171 judgments in light of practice of noncompliance by Member States); Curtin, The Decentralised Enforcement of Community Law Rights, supra note 191 , at 34

474. See Molitor Report, supra note 446 at 53 (“' $[$ S]kepticism about national enforcement can lead to pressures for overly prescriptive measures, even to burdensome common and central regulations at the European level."); Burns, supra note 470, at 443; Yves Mény et al., Introduction, in Adjusting to Europe: The Impact of the European Union on National Instit ur tions and Policies 7 (Yves Mény et al. eds., 1996); see also Stewart, supra note 14, at 66 (in responding to implementation difaculties, principal options open to the Community include adopting highly specia directives, or regulations, so as to reduce discretion).

475. Indeed, enforcement issues help explain the Community's comitology procedure and its analogues, by which the Commission shares delegated legislative authority with hundreds of technical committees stocked with national experts (usually bureaucrats with relevant expertise), as well as expert, scienti ${ }^{\mathrm{a}} \mathrm{c}$, and standards bodies like CEN and various intergovernmental bodies. See Christopher Docksey \& Karen Williams, The Commission and the Execution of Community Policy, in The European Commission 132-35 (Geoffrey Edwards \& David Spence eds., 1994); Rod Hunter \& Koen Muylle, European Community Environmental Law: Institutions, Lawmaking, Enforcement, and Free Trade, 28 Envtl. L. Rep. 10477 (1998). Comitology serves the valuable function of improving coordination with national administrations. See Docksey \& Williams, supra, at 122; Michelle Egan \& Dieter Wolf, Regulation and Comitology: The EC Committee System in Regulatory Perspective, 4 Colum. J. Eur. L. 499, 513-14 (1998); Pollack, supra note 463, at 114-16. At the same time, though, 
Such agreements also improve enforceability by making it easier to identify deviation, ${ }^{476}$ while at the same time increasing the costs to the Commission's credibility should it fail to seek enforcement. ${ }^{477}$ Prescriptive agreements are also more likely to meet the demanding standards of direct effect. ${ }^{478}$ Even though enhancing complexity and detail may make implementation more dif ${ }^{a}$ cult, the offsetting bene ${ }^{a} t$ in terms of enforceability is apparent. ${ }^{479}$

Increasing the intrusiveness of Community legislation, and decreasing the degree of delegation to Member States, undermines the principle of subsidiarity. This is appreciated by those involved in the legislative process. The Commission has complained, for example, that " $[t]$ he delegations which are most in favour of subsidiarity at a political level are often those which call for detailed harmonization at a legal level." It also warned of the risk that subsidiarity

it provides a thoroughly non-transparent means of increasing Member State control over the Commission. See Docksey \& Williams, supra, at 122 ("From a national perspective, the aim is to retain as much in uence for Member States over the Commission as is felt to be necessary when the latter exercises powers of implementation."); Egan \& Wolf, supra , at 517-19; Carol Harlow, European Administrative Law and the Global Challenge, in The Evolution of EU Law, supra note 76 at 274 . The observed tendency of comitology to add complexity to Community acts is variously attributed to the desire by Member States to constrain independent policymaking by the Commission, the in uence of interest-group politics, and the in ${ }^{\circ}$ uence of technical experts. See, e.g., Egan \& Wolf, supra, at 519-22 (applying rational actor/principal-agent, interest group, and public interest theories to development of comitology procedures); Pollack, supra note 463, at 115-16 (emphasizing principal-agent relationship). But it also serves the collective interests of Member States concerned with enhancing the enforceability of Community legislation as against their peers.

476. See, e.g. , Laenerts, supra note 17, at 853 (1994) (stating that Member States' fear of non-reciprocal sharing of the costs of implementation is responsible for the excessively dtailed directives); cf. Anthony Cary, Subsidiarity - Essence or Antidote to European Union?, in Subsidiarity within the European Union: A Federal Trust Report 48-51 (Andrew Duff ed., 1993) (blaming national delegates for level of detail in Community legislation).

477. See Gianomenico Majone, Which Social Policy for Europe, in Adjusting to Europe, supra note 474 , at 129.

478. See Caportiti, supra note 181, at 163-64.

479. The original products liability directive (Council Directive 85/374, 1985 O.J. (L 210) 29) provides an interesting case study of the fate of non-prescriptive directives prior to Francovich. Under the directive, Member States were expressly permitted to exclude certain types of agricultural products from coverage, include a state-of-the-art defense, and limit total liability to not less than 70 million ECU. The combination of unresolved issues and explicit delegations created substantial differences even among those Member States complying fully with their obligations, and many did not comply. See McKenna \& Co., Report for the Commission of the European Communities on the Application of Directive 85/374/EEC on Liability for Defective Products (May 1994); Geraint Howells, Product Liability, in Towards a European Civil Code, supra note 260, ch. 17; Giulio Ponzanelli, The European Community Directive on Products Liability, in Tort Law and the Public Interest: Competition, Innovation, and Consumer Welfare ch. 9 (Peter Schuck ed., 1991) (indicating that caps on damages wound up ranging from approximately $\$ 97$ million in then West Germany to approximately $\$ 68,000$ in Portugal); Duncan G. Smith, The European Community Directive on Product Liability: A Comparative Study of Its Implementation in the UK, France and West Germany, 1990 L. Issues Eur. Integration 101, 101. Most Member States missed the deadline for implementing the directive by a matter of years, and France was ten years late. See McKenna \& Co., supra, at 44-45; Fin. Times, June 4, 1998, at 18. 
initiatives would "encounter[ ] resistance from national administrations which, because of a mutual lack of con $^{\text {a dence, are anxious to }}$ obtain the most detailed regulations possible." ${ }^{80}$ Francovich may untie this knot. More than just a means of overcoming enforcement dif $^{\mathrm{a}}$ culties, the availability of damages may promote subsidiarity both by reducing Community legislation not genuinely supported by Member States and by transforming the nature of the legislation actually enacted. 481

This advantage is rarely stressed, even by those urging an institutional approach. ${ }^{482}$ The potential excesses of such a system, however, have been explored extensively. It has been suggested, for example, that the prospect of liability may encourage Member States to limit their exposure by writing vague legislation that would defeat any attempt at enforcement, ${ }^{483}$ perhaps out of concern that the Court of Justice will not only construe the legislation in a surprising fashion, but also apply that construction in penalizing inadvertent misimplementation by Member States. ${ }^{484}$ This might accentuate the risks already attending legislative subsidiarity, causing effective judicial protection and the Community legislative program to take a step backward. ${ }^{485}$

However likely truly inadvertent breaches may be, ${ }^{486}$ the implicit assumption that inadvertent breaches will give rise to substantial

480. Commission Subsidiarity Report, supra note 240, at 7; see also Scapegoat Seen at the Zoo, The European, June 22, 1998, at 13 (citing objections by Jacques Santer when, following Commission withdrawal of proposed directive on subsidiarity grounds, United Kin gdom proposed equally detailed directive in Council).

481. See Lloyds List, January 3, 1992 ("Those member states who in the future are undecided about a proposal may be more disposed to vote against a proposal rather than go with the tide if they will face anancial penalties for not implementing the legislation at home.").

482. Garrett, for example, sees the Court of Justice's enforcement jurisprudence as esolving an incomplete contracting problem, re $\mathrm{e}^{\circ}$ ecting the general interest of principals in delegating authority. See Garrett, supra note 320, at 557-58; see generally Murray J. Horn, The Political Economy of Public Administration 44-45 (1995) (describing incentives to delegate); $i d$. at 52 (noting that incentives may be outweighed by agency and commitment costs).

483. See Martin, supra note 137 , at 46 .

484. See Harlow, supra note 21, at 209 (asserting that "[i]n the majority of cases, failure to implement is inadvertent ...."), 209-10 (describing Court of Justice's law-making as frustrating attempts by Member States to comply with the law).

485. See, e.g., Snyder, supra note 465, at 203 (arguing that decreasing intensity of Community action, per subsidiarity, is likely to decrease legal controls and transparency of lawmaking).

486. Harlow's cited examples tend to show the more extreme side of the Court's activism. See Harlow, supra note 21, at 209. But the risks seem less acute with the interpretation of directives. See id. at 209-10 (citing examples of surprisingly vague Treaty constructions); see also Walter van Gerven, European Court of Justice Case Law as a Means of Uni "cation of Private Law, 20 Fordham Int' L L.J. 680, 682 (1997) (contrasting "more limited" and "textual" nature of Court's interpretation of directives and regulations to "bold, or even audacious" construction of Treaty provisions and general principles of law). 
liability risks under the prevailing standard seems questionable. ${ }^{487}$ Inadvertent breaches, moreover, are not inevitable. Liability should promote greater care by the responsible entities, including consultations with the Commission regarding the meaning of the directives in question. Further, liability may spur legislative reform by providing an incentive for careful drafting and by eliminating le gislation that is not likely to be implemented. ${ }^{488}$

A more important safeguard against unfair liability judgments lies in the dedication of these issues to national courts in the ${ }^{\mathrm{a}} \mathrm{rst}$ instance. National courts retain ${ }^{a}$ nal authority over the context sensitive evaluation of the ultimate question of liability, in particular as to whether Member States have committed a "sufaciently serious" violation. After Dillenkofer, the complete failure to transpose a drective automatically constitutes such a breach, ${ }^{489}$ as do attempts at implementation that leave evident lacunae. ${ }^{490}$ Imperfect transposition of a directive, however, is actionable only under the Brasserie criteria for seriousness. ${ }^{491}$ Each of Brasserie's non-exclusive, non-

487. See Joined Cases C-46/93 \& C-48/93, Brasserie du Pêcheur, 1996 E.C.R. I-1029, IIII 55-64, [1996] 1 C.M.L.R. 889, IIII 55-64 (1996) (describing circumstances warranting anding of "suf "ciently serious" breach).

488. See supra text accompanying notes $469-470$.

489. Cases C-178 \& 179/94 \& 188-190/94, Dillenkofer v. Germany, 1996 E.C.R. I-4845, IIII 25-26, [1996] 3 C.M.L.R. 469, IIII 25-26 (1996).

490. For example, in its recent decision in Case C-140/97, Rechberger v. Republic of Austria, 1999 ECJ CELEX LEXIS 1882 (Eur. Ct. Justice, June 15, 1999), the Court held that Austria's implementation of the package travel directive by the relevant deadline-January 1, 1995 - but with effect only for tour packages booked after January 1 and with travel commencing after May 1, necessarily constituted a suf ${ }^{\text {c}}$ ciently serious breach warranting Member State liability. Id. at III 44-53; see also Case C-319/96, Brinkmann Tabakfabriken GmbH v. Skatteministeriet, [1998] 3 C.M.L.R. 673, II 28 (1998) (suggesting that failure to implement directive on tobacco taxes through binding rule of law would, under Dillenkofer, constitute per se serious breach of Community law).

In Case C-334/92, Miret v. Fondo de Garantía Salarial, 1993 E.C.R. I-6911, [1995] 2 C.M.L.R. 49 (1993), a case decided before the advent of Brasserie and the requirement of a "serious breach," the Court likewise had no difaculty in anding Spain liable for excluding one class of employees from coverage under the employer insolvency directive. In all of these cases, the de ${ }^{\mathrm{a}}$ ciency in Member State implementation-delaying the effective date within the implementing legislation, the failure to implement through binding legal means, and the exclusion of an entire class of bene ${ }^{\mathrm{a}}$ ciaries - might be defended as tantamount to the failure to implement at all. But see infra text accompanying notes 563-564 (discussing relevance of Brinkmann and Miret for per se rule).

491. Francovich itself contained no such defense, and the Court initially explained that the limitation to "serious" breaches was itself limited to circumstances in which Member States enjoyed "wide discretion." See Joined Cases C-46/93 \& C-48/93, Brasserie du Pêcheur, 1996 E.C.R. I-1029, IIII 50-51, 55 [1996] 1 C.M.L.R. 889, III 50-51, 55 (1996). The Court used a test that, while ill-deaned, resembled the test for preemption. See id. at II48 (German legislature had freedom to act "[i]n the absence of Community harmonisation"); id. at II 49 (Member States deemed to have discretion over the aeld of vessel registration "in view of the state of development of Community law" and over ashing regulation in light of the

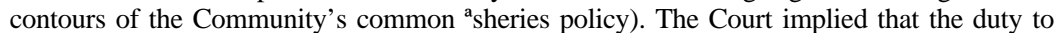
implement directives negated the existence of wide discretion since, among other things, a Member State implementing a directive could not be said to be acting in a situation compara- 


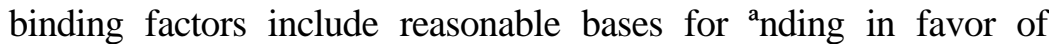
Member States confounded by Community legislation: (1) "the clarity and precision of the rule breached," (2) "the measure of discretion left by that rule to the national . . . authorities," (3) "whether the infringement and the damage caused was intentional or voluntary," (4) "whether any error of law was excusable or inexcusable," (5) "the fact that the position taken by a Community institution may have contributed towards the omission," and (6) "the adoption or retention of national measures or practices contrary to Community law." 492 In British Telecom, for example, the Court excused the United Kingdom's mistaken implementation on the basis of the "imprecisely worded" and ambiguous directive, as well as the lack of guidance from the Court or the Commission. ${ }^{493}$

ble to a Community institution under Article 288 (ex art. 215). This suggested that the seriousness threshold was inapplicable to directives. See id. at TII 46-47. Eventually, though, the Court rejected this implication. See Case C-392/93, The Queen v. H.M. Treasury ex parte British Telecommunications plc, 1996 E.C.R. I-1631, II40, [1996] 2 C.M.L.R. 217, II 40 (1996) (clarifying that "sufaciently serious" test also limits Member State liability for incorrectly transposing a directive); see also Dillenkofer v. Germany, 1996 E.C.R. I-4845, I[23, [1996] 3 C.M.L.R. 469, II 23 (1996) ("[I]n substance, the conditions laid down in [the Court's] judgments are the same, since the condition that there should be a suf ${ }^{\mathrm{a}}$ ciently serious breach, although not expressly mentioned in Francovich, was nevertheless evident from the circumstances of that case.").

492. See Joined Cases C-46/93 \& C-48/93, Brasserie du Pêcheur, 1996 E.C.R. I-1029, II56, [1996] 1 C.M.L.R. 889, ,I56 (1996).

493. See Case C-392/93, Regina v. British Telecommunications, 1996 E.C.R. I-1631, TIII 43-45, [1996] 2 C.M.L.R. 217, ,III 43-45 (1996). In other respects, however, the Court maintains its general reluctance to accept excuses from Member States for implementation dif $^{a}$ culties. In Denkavit, for example, the Court refused to accept the claim by several Member States that Netherland's interpretation was supported by discussions of the directive in Council, replying that the directive's text was controlling. See Cases C-283, 291, \& 292/94, Denkavit International BV v. Bundesamt für Finanzen, 1996 E.C.R. I-5063, [1996] 3 C.M.L.R. 504 (1996). The Court's recent decision in Rechberger, which involved Austria's 'awed implementation of the Package Travel Directive at issue in Dillenkofer, may have altered the landscape. The Court appeared to take up the task of determining whether both of the implementation's alleged de ${ }^{a}$ ciencies - the attempt to make the directive applicable only to travel begun after a certain date, as well as the actual ancial guarantee eventually $\mathbf{f}$ forded by the directive-constituted "serious breaches" warranting state liability. Case C140/97, Rechberger v. Republic of Austria, 1999 ECJ CELEX LEXIS 1882, qI 23 (Eur. Ct. Justice, June 15, 1999).

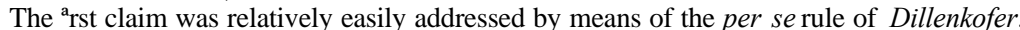
See supra note 406 (discussing claim in Rechberger). The second claim, on the other hand, involved a more subtle breach. Austria's implementing regulation generally required that a minimum of ave percent of the organization's revenue in the preceding quarter be insured or covered by a bank guarantee, but permitted organizers that had been in business for less than one year to estimate their own expected revenue as a basis for the appropriate guarantee. Id. at II 9. The Court might well have regarded that guarantee as constituting a suf ${ }^{\text {ciently serious }}$ breach under the Brasserie du Pêcheur criteria, but it appeared to take a broader approach. In the Court's view, implementation of the directive was improper in all cases in which the national measures failed to achieve the result of providing consumers with a guarantee that all their money would be refunded in the event of an organizer's insolvency. Once it could be determined that there was a direct causal link between the Member State conduct and the damage, any defense the Member State might muster based on the travel organizer's intervening conduct, or other exceptional or unforeseeable events, was irrelevant. Id. at III 54-77. 
It would be difacult to assess whether discretion-conferring drectives are designed more to permit potentially productive variation or to defeat liability. The two goals, however, are not mutually exclusive, and one must presume that the incentive to defeat liability will be contained by the desire of Member States to enact meaningful and enforceable legislative bargains. Such an assumption may be what is meant by subsidiarity.

\section{Maintaining Compliance Through Community Enforcement Measures}

The Commission, not the Court of Justice, is the institution primarily responsible for enforcing Community law, ${ }^{494}$ and the timing of the Court's decision to enhance judicial protection through Francovich was particularly odd. Article 171(2) of the Maastricht Treaty, now Article 228(2), put teeth into then Article 169 (now art. 226) by authorizing the Commission to assess penalties on Member States that fail to comply with judgments. ${ }^{495}$ The Court's failure even to consider these penalties-clearly contemplated at the time Francovich was decided-is regrettable. As a matter of proportionality, the availability of less intrusive Community alternatives is of obvious import. Additionally, the sheer accumulation of Community standards, conferring prosecutorial discretion on both the Community institutions and private parties (and, theoretically, other Member States), poses a threat to Member State autonomy.

\footnotetext{
Rechberger may be read as signi ${ }^{\mathrm{a}}$ cantly retrenching on the Brasserie $d u$ Pêcheur approach to state liability, potentially based on the guarantee-orientation of the directive or its goal of protecting individuals. But while the Court plainly assumed that any breach must be suf ${ }^{a}$ ciently serious to warrant Member State liability, see id. at II 23, its discussion of the second claim appears to have concluded only that the implementation was improper. Id. at III 54-77. Compare ruling 3 (holding that departure-date limitation was sufaciently serious) with ruling 4 (holding only that directive was not properly transposed by virtue of guarantee). As a result, it would appear to be open to the national courts to consider whether state liability was appropriate for those plaintiffs whose trips were booked after January 1, 1995, and who were to depart after May 1, 1995, but for whom the extant guarantee was insufacient. See id. at II 16.

494. See EC Treaty art. 211 (ex art. 155) ("In order to ensure the proper functioning and development of the common market, the Commission shall ... ensure that the provisions of the Treaty and the measures taken by the institutions pursuant thereto are applied ...."); see also Alter, supra note 22, at 125.

495. After considerable delay, the Commission adopted criteria for applying Article 228 (ex art. 171). See Commission of the European Communities, Method of Calculating the Penalty Payments Provided for Pursuant to Article 171 of the EC Treaty, 1997 O.J. (C 63) 2 [hereinafter Method of Calculating Penalty Payments]; Commission of the European Communities, Memorandum on Applying Article 171 of the EC Treaty, 1996 O.J. (C 242) 6. Shortly thereafter, the Commission began initiating proceedings against Member States for the failure to implement important directives, and by the end of 1998, it decided to apply for penalties in 12 cases, involving 6 Member States. In most cases, those Member States reached settlement before Court of Justice proceedings, apparently without incurring penal-
} ties. See Sixteenth Annual Report, supra note 444, at $\S 1.5$. 
Even so, the suggestion that then Article 228(2) made state 1ability unnecessary seems unpersuasive. ${ }^{496}$ Commission proceedings are cumbersome and impose penalties only as a last resort, hence providing little deterrent to foot-dragging. ${ }^{497}$ The penalties procedure is also best suited to different infringements. Some cases not satisfying Francovich standards, such as its requirement that the Community law in question confer rights on individuals, may nonetheless be ripe for an Article 226 proceeding. ${ }^{498}$ State liability, on the other hand, is generally more attractive and better suited to individual complainants. ${ }^{499}$

496. See Harlow, supra note 21, at 225 (suggesting that with the amendment of Article 228 (ex art. 171), "[t]he Community legislator has conceded that the disobedient State shall be sanctioned. The pity is that the ECJ did not leave the matter there.").

497. Article 226 (ex art. 169) requires two "reasoned opinions" from the Commission and two judgments by the Court of Justice before it has fully run its course. Although Member States are ostensibly at risk of inducing delays in this process, they have abundant opportunities to escape scot-free: penalties do not take into account periods before the ${ }^{\text {arst }}$ Court judgment, and if the Member State complies before a second judgment is rendered, no penalties will be imposed at all. See Method of Calculating Penalty Payments, supra note 495, at 2-4 The Commission's "duration" multiplier ranges from one to three, based on the period btween the ${ }^{a}$ rst Court judgment and the second judgment; the resulting daily penalty then accumulates for every day following the second judgment. See id.

498. See Beaumont \& Moir, supra note 366, at 32-182; Anthony Arnull, Dealing with Delinquent Member States, 22 Eur. L. Rev. 101, 101 (1997); Waelbroeck, supra note 179, at 317. For example, it may be dif ${ }^{a}$ cult for individuals to establish that Community environmental directives are intended to confer individual rights (or, for that matter, demonstrate the kind of individual harm that would ultimately be required to obtain damages). See Arnull, supra, at 101 n.4, 102 (citing dif $^{a}$ culties in establishing that directive confers rights); Jane Holder, A Dead End for Direct Effect? Prospects for Enforcement of European Community Environmental Law by Individuals, 8 J. Env. L. 313, 333-34 (1996) (emphasizing difaculties in showing causation in state liability cases); Stewart, supra note 14, at 72-73. But see Jürgen G J Lefevere, State Liability for Breaches of Community Law, 5 Eur. Envtl. L. Rev. 237, 24142 (1996) (indicating cautious optimism regarding the ability of individual claimants to show suf ${ }^{\mathrm{a}}$ cient interest).

499. See Ehlermann, supra note 420 , at 147 . Complainants fundamentally lack control over Commission procedures: its decisions not to proceed against Member States are not subject to challenge, and it is unlikely that private parties could establish standing to bring a challenge even if it were possible. See Case 48/65, Alfons Lütticke GmbH v. Commission, 1966 E.C.R. 19, [1966] 5 C.M.L.R. 378 (1966); see generally Ignace Maselis \& Hans M. Gilliams, Rights of Complainants in Community Law, 22 Eur. L. Rev. 103 (1997); Fifteenth Annual Report on Monitoring the Application of Community Law (1997), 1998 O.J. (C250) 10 [hereinafter Fifteenth Annual Report] (noting lack of power by complainants to affect Commission decisions).

Commission proceedings do, however, offer relative ease and low cost. See Robert M. MacLean \& Joseph Dalby, Enforcing Community Rights Against Member States, 38 J. L. Soc'y Scotland 397, 399 (1993); Jacquelyn F. MacLennan, Decentralized Enforcement of EC Law: Is the European Commission Still the Guardian of the Treaties?, 91 Am. Soc'y Int'1 L. Proc. 159, 167 (1997). These features may be attractive when the small harm to particular individuals would not warrant the cost of litigation. See Arnull, supra note 498, at 101. The Commission has undertaken some procedural reforms to remedy shortcomings. See Fifteenth Annual Report, supra, at 9-10 (resolving, following inquiry by Community Ombudsman, to improve communications with complainants during case and provide notice in most cases before closing inquiries). But the Commission appreciates the limits to its procedures, and so it encourages complainants to resort to state liability actions in national court. See Fourteenth Annual Report, supra note 419, at 12. 
State liability may also be a necessary supplement for political reasons. The Commission has worked hard to earn a reputation as an honest broker, ${ }^{500}$ and increased access of European-level interest groups and concerned individuals may help offset Member State pressure ${ }^{501}$ But the Commission is also a part of a set of Community institutions dominated by Member State governments. ${ }^{502}$ Those governments will invariably be torn between their interests in controlling the Commission as their agent and entrusting it with genuine, unfettered independence. ${ }^{503}$ Because the Commission is less well-positioned than the Court to resist apparent or perceived pressure ${ }^{504}$ any attempt to immunize it from political in ${ }^{\circ}$ uence will $\mathrm{n}$ variably lack credibility and collide with its competing interest in

500. See Ehlermann, supra note 420, at 146 (describing pre-1977 practices of Commission with respect to infringements). More recently, the Commission has attempted to formalize its calculation of penalty payments-including by setting a "uniform 'at-rate amount," and establishing a formula for measuring the deterrent effect of the payment. But it is permitted to exercise discretion as to the seriousness of the infringement. See Method of Calculating Penalty Payments, supra note 495, II 3.1.2 (depending on list of factors, the penalty payment may be multiplied by a coefacient of anywhere from 1 to 20).

501. See generally Sonia Mazey \& Jeremy Richardson, Promiscuous Policymaking: The European Policy Style?, in The State of the European Union: Building a European Polity?, supra note 22, at 337. For a more skeptical assessment of the supranational in ${ }^{\circ}$ uence of these interests, see Beate Kohler-Koch, Organized Interests in European Integration: The Evolution of a New Type of Governance, in Participation and Policy-Making in the European Union, supra note 432 , at 42.

502. See Keohane \& Hoffman, supra note 18, at 13; Elie Cohen, The Interplay of Corporate, National, and European Interests, in Participation and Policy-Making in the European Union, supra note 432, at 157. For these purposes, I include the in ${ }^{\circ}$ uence of national interests using national governments as their agents. See Sonia Mazey \& Jeremy Richardson, EU Policy-Making: A Garbage Can or an Anticipatory and Consensual Policy Style?, in Adjusting to Europe, supra note 474, at 48-50.

503. Compare, e.g., Pollack, supra note 463, at 108-21 (emphasizing mechanisms for Member State control) with Majone, supra note 477 (emphasizing interests in maintaining the Commission's independence).

504. See Pollack, supra note 463, at 108-21. For one, Commissioners are appointed (and, more important, re-appointed) by national governments. See Michelle Cini, The European Commission: Leadership, organisation and culture in the EU administration 110-11 (1996); Finn Laursen, The Role of the Commission, in The European Union: How Democratic Is It?, 120, 137 (Svein S. Andersen \& Kjell A. Eliassen eds., 1996). But see EC Treaty art. 213 (ex art. 157) (describing independence of Commissioners from national interests).

Moreover, Commission personnel must consult and heed national interests in "the shadow of a possible veto" of favored legislation in the Council. See Lisbeth Aggestam, The European Union at the Crossroads: Sovereignty and Integration, in Rethinking the European Union: Institutions, Interests and Identities 75, 84-85 (Alice Landau \& Richard G. Whitman eds., 1997); see also Cini, supra, at 132-33; Klaus Armingeon, The Capacity to Act: European National Governments and the European Commission, in Rethinking the European Union, supra , at 93, 98. This means that the Commission may be reluctant to pursue an action against a Member State while important legislation is pending in the Council, lest the Member State "manifest its displeasure by rendering the passage of the legislation more protracted." Craig, supra note 471, at 455-56.

Finally, since the Single European Act, the Commission is subject to the risk-however slight in practice - that the comitology procedure will refer its measures to the Council. Pollack, supra note 463, at 114-16. This threat may establish substantial control over the Co mmission. See id. at 115; Cini, supra, at 132, 225. 
maintaining prosecutorial discretion over the infringement actions it brings. ${ }^{505}$

The Commission's lack of genuine autonomy ${ }^{506}$ and suf ${ }^{\mathrm{a}}$ cient resources $^{507}$ suggests that state liability will be a much more effective deterrent, as the Commission itself has conceded. ${ }^{508}$ Paradoxically, perhaps, subsidiarity considerations also decisively favor it. The Article 226 process employs a Community enforcement authority, working exclusively through judgments obtained from the Court of Justice. Unlike Article 234 (ex art. 177), in which the Court is con $^{\mathrm{a}}$ ned to interpreting Community law, the Article 226 procedure aims at a judgment that the Member State in question has failed to ful $^{\mathrm{a} l} \mathrm{a}$ Treaty obligation - a more invasive result, arguably, than any damages remedy. ${ }^{509}$ Moreover, that procedure empowers the Court

505. See Snyder, supra note 19, at 30-31 (discussing the use of litigation in the Commission's long-term negotiating strategy in Article 169 cases). Since every protracted enforcement action potentially exposes the Commission to political costs, the Commission appears to have adopted the strategy of aiming "at only the most obvious and uncontestable forms of non-implementation, such as the failure to enact timely national legislation to carry out a Community directive." See Stewart, supra note 14, at 67. The Commission's near-perfect track record in infringement proceedings re ${ }^{\circ}$ ects this phenomenon. But see Case C-300/95, Commission v. United Kingdom, 1997 E.C.R. I-2649 (rejecting infringement action against United Kingdom concerning its implementation of the Product Liability Directive).

506. See, e.g., Armingeon, supra note 504, at 98-99; MacLennan, supra note 499, at 168; Pollack, supra note 463, at 119-20. For a fascinating account of the Commission's reluctance to intervene against Member States that fail to implement properly environmental directives, see Rhiannon Williams, The European Commission and the Enforcement of Environmental Law: An Invid ious Position, 14 Y.B. Eur. L. 351 (1994).

507. See Ehlermann, supra note 420, at 146; e.g., Green Paper on Public Procurement in the European Union: Exploring the Way Forward (Nov. 27, 1996) at II 3.42 <http://europa.eu.int/comm/dg15/en/publproc/green/gpentoc.htm> ("The Commission has neither the resources, nor the information, to identify and resolve each and every breach of Community rules throughout the EU. From a practical point of view, the vast majority of individual problems encountered by economic operators should be tackled at national level.").

508. See Ehlermann, supra note 420, at 147 (suggesting that due to enormity and diversity of infringement issues, "centralized control alone will never ensure that Community law is observed in all Member States, whatever effort is made to strengthen [it]"); see also Ball, supra note 72, at 334-35; Curtin, supra note 191, at 34; Robert D. Sloane \& Pascal Cardonnel, Harmed by EC Law Con ${ }^{\circ}$ ict, Legal Times, Sept. 9, 1996, at S31; Lenaerts, supra note 17, at 892 .

509. Even if no penalty is imposed-for example, if a settlement is reached after the in itial Article 226 judgment is rendered-that judgment is still effective erga omnes and ex tunc. The practical effect may seem slight, if only by virtue of the frequency with which such judgments have been obtained. See, e.g., Fines on EU States Could Be Problematic, Says Court President, Eur. Comm. Rep., Oct. 12, 1994. Still, such judgments can serve as the basis for injunctive and declaratory relief (even for non-litigants) in a way that the mere construction of Community law by the Court of Justice, or even a anal determination of liability by national courts, does not. See Prechal, supra note 43, at 29-31; see also Arjen W.H. Meij, Article 215(2) EC and Local Remedies, in The Action for Damages in Community Law 273, 275-77 (Ton Heukels \& Alison McDonnell eds., 1997) (distinguishing on similar grounds between action for Community damages under Article 288 (ex art. 215) and actions seeking a declaration of invalidity or annulment under Articles 234 (ex art. 177) and 233 (ex art. 176)) $c f$. Wägenbaur, supra note 471, at 944 (judgment under Article 288(2) (ex art. 215 (2)) could detail measures necessary for compliance and cessation of penalties). Injunctive relief is 
of Justice, rather than the national courts, to determine whether Member States have breached Community law. ${ }^{510}$

State liability, in contrast, entrusts enforcement to private individuals relying primarily on national courts. Unless Community liability standards prove too onerous, it is eminently more respectful of Member States' autonomy to wrest the impetus for enforcement from a federal actor and rely initially on national institutions for adjudication. ${ }^{511}$ Indeed, the potential ef ${ }^{\mathrm{a}}$ cacy of state liability relies very much on the virtues of localism, since many believe that the proximity and local legitimacy of national courts may make it much more difacult for Member State governments to ignore adverse judgments. ${ }^{512}$ The remaining question, perhaps, is whether national courts will be suf ${ }^{a}$ ciently willing to render such judgments.

\section{Can National Courts Suf ${ }^{\mathrm{a}} c e$ ?}

Francovich's most appealing claim thus may be to deter Member State non-compliance, thereby improving prospects for coordination. But Francovich's potential weaknesses are evident: there is little hard evidence concerning the incentive effects of government liability, ${ }^{513}$ leaving room for doubt whether and to what extent public institutions internalize and react to the costs (or bene ats) of noncompliance. ${ }^{514}$ To skeptics, Francovich accentuates these limita-

often more intrusive than damages. See Schuck, supra note 416, at 14-16. But see Christina Whitman, Constitutional Torts, 79 Mich. L. Rev. 5, 47-56 (1980) (advocating use of equitable remedies in cases involving 42 U.S.C. $\$ 1983$ ). For a concise description of the advantages of liability over judicial review and injunctive relief, including the minimal intrusiveness of damages remedies and the diminished prospect for $\operatorname{con}^{\circ}$ ict between the judicial and political authorities, see Latournerie, supra note 413, at 222-24.

510. See Bermann, supra note 33, at 294; C.W.A. Timmermans, Judicial Protection Against the Member States: Articles 169 and 177 Revisited, in Institutional Dynamics of European Integration, supra note 12, at 404. But see Waelbroeck, supra note 179, at 323-24 (noting that decisions in British Telecom and Brasserie du Pêcheur, by appearing to apply Community law to facts, blur distinction between Article 226 (ex art. 169) and Article 234 (ex art. 177) matters).

511. See, e.g., Lenaerts, supra note 17, at 892-93.

512. See, e.g., Beaumont \& Moir, supra note 366, at 32-181; see also G. Federico Mancini \& David Keeling, From CILFIT to ERT: The Constitutional Challenge Facing the European Court, 11 Y.B. Eur. L. 1, 10 (1991) ("Francovich gave to Article 169 .. . claws and teeth that are far sharper and more incisive than those concocted by the authors of the Maastricht Treaty.").

513. See Anthony W. Bradley \& John Bell, Governmental Liability: A Preliminary Assessment, in Governmental Liability, supra note 139, at 16; Ronald A. Cass, Of cial Liability in America: Actors and Incentives, in Governmental Liability, supra note 139, at 142.

514. See, e.g., Cohen, supra note 453, at 246-57 (arguing that budgetary and payment mechanism factors in Canadian federal government limit effect of liability in reducing accident costs); id. at 257-62 (other limits to effectiveness of government liability); see also Baxter, supra note 416, at 45-52 (noting uncertainties surrounding deterrence function of government liability). Compare Harold J. Krent, Preserving Discretion Without Sacri ${ }^{a}$ cing Deterrence: Federal Government Liability in Tort, 38 UCLA L. Rev. 871, 885 (1991) ("[T]he government - just like any private enterprise — would minimize the sum of prevention and 
tions by entrusting the enforcement of a vague standard to the $\mathrm{m}$ tional courts, some of which have a proven record of resisting Community law, ${ }^{515}$ and all of which are subject to some in ${ }^{\circ}$ uence by national governments interested in resisting liability. ${ }^{516}$

Francovich was indeed decided without any clear indication that government liability worked, perhaps inclining the Court toward mere rights-oriented explanations. ${ }^{517}$ There is, however, some evidence of its subsequent success. The Commission's data on infringements show mixed but encouraging results in the overall level of implementation since Francovich was rendered. While improved Commission procedures ${ }^{518}$ and legislative reforms may be credited, ${ }^{519}$ the advent of state liability may be another reason behind the decrease in the number of complaints. ${ }^{520}$

accident costs if forced to internalize the costs of its actions."), with Harlow, supra note 21, at 209 ("Everything suggests ... that we are talking here of conduct which cannot be $d-$ terred."). Weighing some of these issues, the most sophisticated attempt to determine whether Francovich deterred government breaches simply concluded that "[i]n the absence of any good theory at hand to map political costs into money values and vice versa, allowing for a measure of comparison between political costs and liability costs, it seems defensible to treat them as being linearly related." van den Bergh \& Schäfer, supra note 436, at 559.

515. Even those generally endorsing the adelity of national courts to Community law note the potential bounds to their enthusiasm and the discrepancies in their actual promotion of it. See Mattli \& Slaughter, supra note 404, at 253-76. For general accounts of the process by which national courts adapted to Community law supremacy, see Schermers \& Waelbroeck, supra note 53, at 127-38; Mattli \& Slaughter, supra note 404, at 190-96.

516. See Harlow, supra note 21, at 210 (noting that the "vague formula" for attaching liability not only "point[s] to the likelihood of a rich and nuanced jurisprudence from national courts but it cuts the ground from under sanctions and deterrence arguments"); Imelda Maher, National Courts as European Community Courts, 14 Legal Stud. 226, 235 (1994) ("As a cheap form of Community law enforcement, the system is inevitably weak as courts remain entrenched within their national legal orders."); $c f$. Richard A. Posner, The Federal Courts: Challenge and Reform 280 (1996) (Whenever incentive-based accounts of federalism "would assign substantive lawmaking responsibility to federal rather than state governments, there is an argument for assigning to the federal courts jurisdiction.").

517. Pre-Francovich liability regimes were so diverse as to frustrate any attempt at comparison, and even the more progressive liability regimes had very little experience with claims seeking damages for Community law violations. Some of the most liability-friendly systems, however, showed little comparative advantage in the implementation of directives. See Auke Baas, The Netherlands in Face of Its Community Obligations 1984-1995, 33 Common Mkt. L. Rev. 1197, 1197-1202 (1996) (noting continuing difaculties of Dutch government in non-implementation, non-conformity, and incorrect application, and suggesting that Commission implementation statistics overstate compliance).

518. See Sixteenth Annual Report, supra note 444, at 8-11.

519. The advent of legislative subsidiarity, on the one hand, should have slowed (marginally) the pace of Community legislation, increased (marginally) its clarity, and decreased (marginally) the burden on Member States. But the development of qualiaed-majority voting in the Council, and the resulting tendency toward reduced consensus behind adopted measures, should have increased the risk of non-implementation. See Bednar et al., supra note 231, at 280; Ehlermann, supra note 420, at 145; Stewart, supra note 14, at 51.

520. See Timmermans, supra note 510, at 393-94 (surmising that increased number of complaints lodged with Commission and infringement procedures commenced through 1992 indicated mounting compliance problems). One might guess that the backdrop of state liability would increase the effectiveness of Article 226 (ex art. 169) letters issued by the Commission. But the in terrorem effect of Article 226 seems to have changed very little since Fran- 
There is also anecdotal evidence that state liability works. The liability risks posed by governmental breaches of Community law have entered the public and political consciousness. ${ }^{521}$ Some of the ${ }^{a}$ rst cases, moreover, have at least demonstrated speci ${ }^{\mathrm{a}} \mathrm{c}$ deterrence. 522 Italy itself implemented the directive at issue in Francovich just two months after the decision, together with a compensation scheme. ${ }^{23}$ The Court has since claria ed that Italy's compensation must provide for consequential damages as well, thereby compensating claimants for the passage of time and preventing governments from pro ating from delay. ${ }^{524}$ In another instance, less than one year after British Telecom lost its liability case in the Court of Justice, the Court's indication that the United Kingdom had improperly implemented the directive in question enabled the company to obtain prospective relief in national court. 525

These achievements exceed, to be sure, Francovich's success in delivering compensation, which has often been slow to come or nonexistent. ${ }^{526}$ A deterrence-based justi ${ }^{a}$ cation for Francovich

covich and looks like it took a precipitous drop in 1997- though that may be to the devaluation of the Article 226 letter, which the Commission now regards as "a de-dramatized request for observations." See Thirteenth Annual Report on Monitoring the Application of Community Law, 1996 O.J. (C 303) 1, 71-72 (statistics for 1991-1992); Fifteenth Annual Report, supra note 499, at 90-94 (1993-1997).

521. The evidence is most pronounced in the United Kingdom, which featured perhaps the most restrictive pre-Francovich liability regime, and in which politicians and the public have what might be described charitably as a skeptical attitude toward the dictates of Community law. See, e.g., Jackie Davis \& Christopher Leake, Euro Military Chiefs Blast 'Inhuman' MOD; Britain Under Fire as the Bill for Pregnancy Sackings is Set to Hit £100, Mail On Sunday, June 19, 1994, at 22 (describing potential liability of British government for discriminatory conduct in violation of Equal Treatment Directive at more than $£ 100$ million); Chris Ayres, Rights Case to Earn Millions for Employees, Times (London), Nov. 17, 1997 (indicating that compensation for public sector employees dismissed or transferred in violation of the Acquired Rights Directive was likely to amount to millions of pounds). Even at the other end of the spectrum, the Dutch Secretary of State was quite explicit in citing the advent of the Francovich doctrine as an added incentive to improving Dutch implementation. See Baas, supra note 517, at 1202 (citing lecture by Secretary of State for European Affairs Dankert, Dec. 4, 1992, reprinted in Staatscourant, Dec. 3, 1992 (no. 235), at 2).

522. In a number of cases (e.g., Factortame, Dillenkofer) the government had already taken measures to comply before the action for damages was commenced.

523. See Decreto legislativo n.80 del. 27/01/1992.

524. See Case C-373/95, Maso v. INPS, 1997 E.C.R. I-4051, [1997] 3 C.M.L.R. 1244 (1997); Case C-261/95, Palmisani v. INPS, 1997 E.C.R. I-4025, [1997] 3 C.M.L.R. 1356 (1997); Joined Cases C-94 \& 95/95, Bonifaci v. INPS, 1997 E.C.R. I-3969, [1998] 1 C.M.L.R. 257 (1997).

525. See R v. Her Majesty's Treasury, ex parte British Telecommunications Plc, OC/551/93, (Eng., Q.B.D 1996).

526. The most poignant example is that of Andrea Francovich, who ultimately learned that because his employer was not among those covered by the insolvency directive, he would not recover any compensation under the principle his case created. See Case 479/93, Francovich v. Italy (Francovich II), 1995 E.C.R. I-3843; see also van den Bergh \& Schäfer, supra note 436, at 561 (conceding that the standard in Brasserie du Pêcheur "will preclude recovery in most instances"); Harlow, supra note 21, at 207; van Gerven, Bridging the Unbridgeable, supra note 210 , at 516 n. 42 . 
scarcely requires, or endorses, such a result. ${ }^{527}$ At the same time, adequate deterrence may be achieved even if not all parties suffering due to non-implementation are compensated. What is important, instead, is that compensation failures not be so widespread as to undermine either the incentive to sue (and thus the threat of liability) or the rough calculus of governments measuring the costs of non-compliance. The key is a Member State's ex ante anticipation, rather than the results in any particular case. ${ }^{528}$ Even a small likelihood of redress may provide a suf ${ }^{a}$ cient incentive when the Member State would also fail to appropriate the total bene ${ }^{a} \mathrm{t}$ of nonimplementation.

Member States may, of course, be tempted instead to restrain the independence of court rendering liability judgments, but there are sound reasons to believe they would hesitate to do so. The institutional theory of liability advanced above stresses the interest of national governments in promoting compliance and good faith implementation of the Community liability standard.529 In addition, the horizontal dimension of Community law also means that underenforcement of a given Community standard may have a tangible price: any persuasive minimization of liability may be cited by other national courts as a basis for excusing their own governments, or even inspire adoption by the Court of Justice.

527. Accordingly, nothing in the institutional argument described here requires concluding that "deterrence is a more important policy goal than compensation." Harv. L. Rev., Note, supra note 416, at 2014 n.61; see also Richard H. Fallon, Jr. \& Daniel J. Meltzer, New Law, Non-Retroactivity, and Constitutional Remedies, 104 Harv. L. Rev. 1731, 1789 (1991) (failures of redress tolerable, but not so systematic public lawlessness). But see Baxter, supra note 416 , at 52 (in light of uncertainties attending deterrence function, compensation most persuasive goal of government liability).

Van den Bergh and Schäfer, however, defend the post-Brasserie jurisprudence on the grounds that denying compensation in some instances is necessary to prevent over-deterrence of government of ${ }^{a}$ cials, see van den Bergh \& Schäfer, supra note 436, at 560-61, but they provide no credible explanation of how over-deterrence might be occasioned. Their analysis focuses solely on ef ${ }^{a}$ ciently incenting compliance with Community law without analyzing the ef ${ }^{a}$ ciency of the underlying legislation, see id. at 557, and they assume that public authorities are directly responsive to monetary incentives, see id. at 559. Their sole example of overdeterrence, however, is the prospect that Member States will literally copy directives into domestic law without further systematically integrating the law into their distinctive legal order. See id. at 557. It is by no means clear that doing so would insulate the Member State from liability under a more demanding approach. See Prechal, supra note 43, at 36-37 (discussing hazards attending verbatim reproduction of directives). In any event, for the reasons explained in this Article, I believe the advantage of the Brasserie approach is better expressed in terms of subsidiarity.

528. See Eeckhout, supra note 189, at 64.

529. The intergovernmentalists recognize this point in principle. See Garrett, supra note 466, at 172-73. ("Where the broader beneats a government derives from having an effective legal system underpinning the internal market outweigh the speciac domestic costs associated with the court's ruling in a given case, the government's rational strategy will be to accept the decision."). 
Further, enforcement through national courts have some distinct advantages over depending solely on the Court of Justice, which itself is hardly free from political pressure. ${ }^{530}$ For one, national courts desiring to resist domestic political pressure have a relatively compelling argument that they lack discretion. While the Court of Justice may rely only on the self-imposed restrictions of its own precedents, national courts can shift blame to the Court of Justice, particularly if it has previously opined in pre-liability proceedings on the exact issue at hand.531

A second advantage stems from the mechanics of preliminary references. As previously noted, national courts of last resort must request the Court of Justice's assistance in construing Community law, though it is dif ${ }^{\mathrm{a}}$ cult to force them to; recognizing that, Article 234 (ex art. 177) makes it permissible (but not incumbent upon) lower national courts to seek the Court's assistance on their own behalf. ${ }^{532}$ This system makes it dif ${ }^{a}$ cult for the Court of Justice to systematically rationalize law among Member States. At the same time, it disaggregates local judicial preferences in a manner likely to defeat all but the most concerted anti-Community bias. If a m-

530. See Garrett, Keleman, \& Schultz, supra note 154, at 171-74 (assuming that national governments regarded Francovich as adverse, and Court of Justice has anticipated reaction and adapted its jurisprudence); see also Trevor C. Hartley, The Foundations of European Community Law, 207, 211-18 (4th ed. 1998) (suggesting that lack of horizontal direct effect for directives represents concession by Court of Justice to Member States). A comparative assessment of judicial independence in the European Community is clearly beyond the scope of this Article; it is not clear, indeed, that there is any universal basis for assessing judicial independence. See Eric Rasmusen, Judicial Legitimacy as a Repeated Game, 10 J.L. Econ. \& Org. 63, 65 n.4 (1994). At a basic level, though, both the Community and Member States have attempted to foster judicial autonomy. The national processes for selecting ECJ justices are reportedly without great emphasis on judicial (as opposed to more conventional) politics, and post-hoc policing is made more dif ${ }^{\mathrm{a}}$ cult by the anonymity of Court judgments. See Alter, supra note 22, at 139. Still, the relatively short six-year terms of the justices, combined with the possibility of reappointment, continues to raise concerns, and the Amsterdam IGC entertained a proposal from the $\mathrm{Re}^{\circ}$ ections Group that would lengthen the term and eliminate reappointment for precisely these reasons.

For their part, national judiciaries-with the arguable exception of the French Constit utional Council—are also cultivated with an eye towards their autonomy. See, e.g., John Bell, Principles and Methods of Judicial Selection in France, 61 S. Cal. L. Rev. 1757, 1786-92 (1988); David S. Clark, The Selection and Accountability of Judges in West Germany: Implementation of a Rechtsstaat, 61 S. Cal. L. Rev. 1795 (1988). Each Member State has something of the same incentive as the Community to promote independent judicial review. But to the extent that national governments can secretly compromise that autonomy with respect to Community law without sacri ${ }^{a}$ cing the judiciary's integrity with respect to domestic matters, they have a clear incentive to do so.

531. $C f$. Burley \& Mattli, supra note 52, at 69 (noting judiciary's interest in creating pparent separation between law and politics, and promoting impression that controversial decisions are legally compelled). The argument that an application favoring liability is legally compelled is much more persuasive when made by a national court: given the Court of Justice's integrationist biases, many would doubt its claims to be constrained, but a national court can more convincingly argue that it had no choice but to follow the precedent of the Court of Justice.

532. See EC Treaty art. 234 (ex art. 177). 
tional court desires to promote Community law enforcement, but fears abreaction or retaliation, it may invoke the Court's assistance and the constraint of its guidance. As Karen Alter has stressed, lower courts willing to overlook national policy preferences may use this procedure to "compete" with the contrary leanings of higher courts by circumventing local hierarchy and going straight to the Court of Justice. ${ }^{53}$ This maximizes the opportunity for proCommunity input and multiplies the arenas in which those opposed to liability must seek to obtain and exercise in ${ }^{\circ}$ uence.

To date, national application of Francovich has generally been reassuring as to its deterrence potential. At the same time, it suggests the valuable role that the Court of Justice can play. ${ }^{534}$ The most obvious examples may be the decisions by the U.K. and German courts following the joined judgment in Brasserie du Pêcheur and Factortame III, given the political strength of their respective governments, their clear opposition to imposing liability under those circumstances, and the degree to which domestic law diverged from Francovich. ${ }^{535}$ Undoubtedly attuned to these consid-

533. See Alter, supra note 404, at 241-46 (elaborating theory of inter-court competition). Alter suggests a dichotomy between lower courts, which often (but not inevitably) have an interest in subverting the national legal order by making references to the Court of Justice, and higher courts, which have an interest in frustrating the local application of Community law; the data on preliminary references does not necessarily bear out this distinction. See Alec Stone Sweet \& Thomas L. Brunell, The European Court and the National Courts: A Statistical Analysis of Preliminary References, 1961-95, 5 J.European Pub. Pol. 66, 71, 9091 (1998). The distinction is probably less signiacant than the possibility of multiple judicial interests in any given Member State.

534. But see van Gerven, supra note 139, at 46 n.50 (describing recent cases as reinforcing view that "leav[ing] the de ${ }^{a}$ nition of these essential conditions entirely to the national legal orders . . . would amount to a de facto 'renationalisation' of the Community law principle of state liability").

535. In contrast, the faithful application of Francovich in the Netherlands, see, e.g., Lubsen/Netherlands, Dist. Ct., Utrecht, 25 October 1995, Jurisprudentie Bestuursrecht 305, ann. Lefevere [hereinafter Lubsen], is probably unsurprising in light of preexisting Dutch law. See Shapiro v. Netherlands, 1996 Rechtspraak Algemene wet bestuursrecht 90 (D. Ct. Hague, Feb. 14, 1996) (rejecting liability claim on national-law grounds parallel to Francovich).

French precedent, as previously noted, effected state liability on a somewhat different basis. For example, several postFrancovich decisions by the French courts have attempted to steer between the traditional prohibition against ${ }^{a}$ nding statutes illegal and the high burdens attending a claim for breach of the principle of equality. In Société Arizona Prods. \& Société Anonyme Philip Morris France [Arizona Tobacco Prods. GmbH Export KG \& Philip Morris France SA], [1993] 1 C.M.L.R. 253 (Conseil d'Etat 1992), the Conseil d'Etat considered whether the French government was liable for its repeated failure to conform national law imposing price controls on tobacco to Directive 72/464, in the teeth of two judgments of the Court of Justice. See Case 90/82, EC Commission v. France (Re. Tobacco Prices), 1983 E.C.R. 2011, [1984] 2 C.M.L.R. 516 (1983); Case 169/87, EC Commission v. France (Re. Tobacco Prices (No. 2)), 1988 E.C.R. 4093, [1990] 1 C.M.L.R. 49 (1988). The Conseil d'Etat concluded that the ministerial decisions adopted pursuant to national law were illegal and awarded damages, see Arizona Tobacco Prods. GmbH Export KG \& Philip Morris France SA], [1993] 1 C.M.L.R. 253, II3 (Conseil d'Etat 1992), thus avoiding the more delicate problem of attaching liability to the legislative acts themselves. See Rochère, supra note 458 , at 198 (noting that "it is also fair to observe that the amount of indemnity allowed is very low 
erations, and to the potential enormity of British liability, ${ }^{536}$ the Court of Justice gave particularly strong signals that the United Kingdom should be held liable. The High Court followed the Court of Justice's lead relatively closely, ${ }^{537}$ but the Court of Appeal thereafter emphasized that the Court of Justice's opinion was not binding, but more of a "steer" in the right direction. The Court of Appeal then exercised its independent judgment in extending the scope of the government's liability for the legislation's domicile and residence conditions. ${ }^{538}$ On the whole, the proceedings show how, with more than a modicum of arm-twisting from the Court of Justice, national courts can demonstrate resilience in the face of continued government intransigence.

The Bundesgerichtshof's holding following the Court of Justice's decision in Brasserie du Pêcheur is a little more problematic. It rejected the plaintiff's claim for damages, concluding that a provision of German law deemed not to constitute a suf ciently serious breach-a prohibition on using certain additives in beer-was the true cause of the plaintiff's injury, not the designation of origin provisions (which were considered suf ${ }^{a}$ ciently serious). ${ }^{539}$ The German court's analysis of causation may be ${ }^{\circ}$ awed on its facts, ${ }^{540}$ and might be thought to foreshadow the subversion of state liability by $\mathrm{m}-$ tional tribunals. At the same time, as the court's reasoning emphasized, the purported link to the non-serious breach was important only because Germany had taken immediate steps to comply with the Court of Justice's judgment relating to the other breach. This

compared with the sums which had been asked for"); cf. Jens Plötner, Report on France, in The European Courts and National Courts, supra note 404, at 48 (suggesting that Arizona Tobacco complies with both Francovich and Bonifaci, but alluding to problems with "the legal basis" insofar as it fails to acknowledge absolute supremacy of Community law).

Very shortly thereafter, the Paris Court of Administrative Appeal took the next step, in effect holding Parliament liable-without any intervening regulatory action-for failure to implement the Sixth Value Added Tax Directive. See Société Jacques Dangeville, CA Paris, July 1, 1992, No. 89PA02498, 1992 A.J.D.A. 768, note Pretot; Errera, supra note 458, at 535-37 (suggesting that Dangeville was fully consistent with Francovich). By affording a damages remedy, however, the Cour d'Appel plainly circumvented an earlier decision by the Conseil d'Etat denying restitutionary relief to the same plaintiff, see Société Anonyme "Cabinet Jacques Dangeville" c. Ministre de l'Economie, des Finances et du Budget, Conseil d'Etat, Mar. 19, 1986, Lebon No. 46.105 (table), which undoubtedly contributed to its summary reversal on further appeal. See Ministre du Budget c. Société Jacques Dangeville, Conseil d'Etat, Oct. 30, 1996, Lebon NC 141043.

536. News reports suggested that approximately 100 million pounds may ultimately be at stake. See Tim Jones, Spanish Fishermen Win Right to Claim for Losses, Times (London), Apr. 9, 1998.

537. See R. v Secretary of State for Transport, ex parte Factortame and Others, [1998] 1 C.M.L.R. 1353, 1407 (High Ct., Q.B. Div., 1997).

538. See R. v. Secretary of State for Transport, ex parte Factortame, [1998] 3 C.M.L.R. 192 (Ct. App. (Civ. Div.), 1998).

539. See Brasserie du Pêcheur SA v. Germany, [1997] 1 C.M.L.R. 971 (Bundesgerichtshof [BGH] [Supreme Court], 1996).

540. See Tridimas, supra note 25, at 29. 
isolated the less serious breach as the source of the plaintiff's troubles - and, not incidentally, stressed in a non-confrontational fashion the importance of prompt compliance in diminishing liability.

None of this is to downplay important counterexamples in which neither deterrence nor compensation were well-served. ${ }^{541}$ The risk of such decisions increases, moreover, when state liability law grows more settled, such that national courts may defensibly decline to refer questions of Community law to the Court of Justice.

The national decisions so far, however, demonstrate that state liability at least rivals the Commission's infringement proceedings in apparent effect. One useful illustration stems from the United Kingdom's implementation in 1981 of the Transfer of Undertakings Directive (known as the Acquired Rights Directive in the U.K.), ${ }^{542}$ in which it controversially limited the directive's application to transfers "in the nature of a commercial venture"-thereby excluding governmental contracting-out decisions, to the government's apparent bene ${ }^{a} .^{543}$

541. See, e.g., Regina v. Secretary of State for the Home Department, ex parte John Gallagher, [1996] 2 C.M.L.R. 951 (U.K. C.A.(Civ. Div.) 1996). The Court of Justice had held that the United Kingdom's Prevention of Terrorism (Temporary Provisions) Act 1989 was inconsistent with Council Directive 64/221 insofar as it permitted the administrative authority to order expulsion before a competent authority had rendered its opinion. In subsequent proceedings seeking damages, the Court of Appeals held that the applicant had failed to show that the United Kingdom's breach was more likely than not to have caused his exclusion from the United Kingdom. In addition, the Court held that the United Kingdom's departure from the procedure contemplated by the directive, while "manifest," was not sufaciently "grave" to constitute a serious breach, since the owed procedure nevertheless may have been thought to provide effective protection.

Causation, the Court's principal basis for decision, was decided in a manner not unlike that followed by Article 288 (ex art. 215) case law, which has required a showing that the wrongful act of the Community was the direct, immediate, and exclusive cause of the injury. See A.G. Toth, The Concepts of Damage and Causality as Elements of Non-contractual Liability, in The Action for Damages in Community Law, supra note 334, at 191-98. But the Court of Appeals' holding on the seriousness prong is dubious, as is its reliance on the Court of Justice's decision in Hedley Lomas. As the Court of Appeals recognized, Hedley Lomas involved a circumstance in which the national of ${ }^{a}$ cials had little or no discretion. It does not follow, however, that the mere presence of legislative judgment means that a serious breach has not been committed; the closer analogue was British Telecommunications, which the Court of A ppeals invoked but then essentially ignored.

542. Council Directive 77/187 EEC on the approximation of the laws of Member States relating to the safeguarding of employees' rights in the event of transfers of undertakings, businesses or parts of businesses, 1977 O.J. (L 61) 27.

543. See Transfer of Undertakings (Protection of Employment) Regulations 1981, S.I. 1981 No. 1794, reg. 2(1); see Clare Dyer, Government Knew It Broke European Law, Guardian (London), June 10, 1994, at 4 (citing evidence of 1983 government legal advice to the effect that commercial venture limitation was unlawful); see also Paul Gosling, Public Services Management: Trying to Make Amends for the Regulatory Errors, Independent (London), July 29, 1993, at 23 (asserting that "[g]overnment, councils and contractors privately have accepted for some time that contracting out can fall under the Acquired Rights Directive. It would not even be a matter of debate but for an error by the Government . ..."). It would, however, appear that France and Germany took the same view, at least for a time. See Rodney Hubson, Will Tupe Safeguard Jobs?, Times (London) Feb. 22, 1995. 
Because the Commission aled an Article 169 action in 1992, and the United Kingdom amended its domestic provisions in mid1993, ${ }^{544}$ the Commission understandably considers the episode to vindicate its infringement procedure. ${ }^{545}$ But it took eleven years before the British deviation from the directive was formally brought to the Court's attention, then several more years following the Court's judgment before infringement proceedings reached the eferral stage. ${ }^{546}$ The United Kingdom, moreover, will likely emerge without paying any penalty for tardy implementation. ${ }^{547}$ There is reason to think that the more tangible threat of damages was equally important in spurring legislative reform. ${ }^{548}$ Indeed, aware of favorable judicial precedent construing the directive, ${ }^{549}$ not to mention Francovich, ${ }^{550}$ union leaders highlighted the prospect of damages actions in pressing for legislative revision in $1992,{ }^{551}$ and the

544. Trade Union Reform and Employment Rights Act 1993, section 26. For a succinct history, see UK Waste Control Ltd. v. Wren, 1995 I.C.R. 974 (Emp. App. Trib.).

545. See Fifteenth Annual Report, supra note 499, at 9; Gosling, supra note 543, at 23; Jonathan McLeod, Undermining Ministers Over Undertakings-EC Law on the Transfer of Undertakings, 90 L. Soc'y Guardian Gazette, May 26, 1993, at 14; Gillian More, The Acquired Rights Directive and its Application to Public Sector Contracting Out, 18 Eur. L. Rev. 442, 443 (1993).

546. The Commission notia ed the United Kingdom of several defects in 1989, and after encountering resistance, issued in 1991 a reasoned opinion containing a new deadline for compliance. The United Kingdom replied by indicating that its legislation required "clariacation" as to three of the discrepancies highlighted by the Commission, without admitting that its laws were inconsistent with the directive. The Court ruled in the Commission's favor in 1994, anding the U.K. regulations defective as to the commercial ventures limitation and in three other respects. See Case C-382/92, Commission v. United Kingdom, 1994 E.C.R. 2435, [1995] 1 C.M.L.R. 345 (1994). Under settled Community law, the changes in the U.K. law did not moot the issue before the Court, since they had not been adopted before the end of the period provided for in the Commission's reasoned opinion. See Opinion of Advocate General van Gerven, Case C-382/92, Commission v. United Kingdom, 1994 E.C.R. 2435, If 22, [1995] 1 C.M.L.R. 345, II 22 (1994)

547. The Commission later commenced Article 171 proceedings against the United Kin gdom for its failure to abide by portions of 1994 judgment relating to its failure to provide for consultation with workers' representatives. See Five Unions to Sue Government, Press Ass'n Newsale, Nov. 30, 1993. It observed, however, that British authorities were crafting amendments to bring the legislation into compliance. See Fifteenth Annual Report, supra note 499, at 194 .

548. See Jane Moorman, Legal Update: Keeping Hold of Your Rights When Those in Charge Change, Guardian (London), May 20, 1995, at 2 (discussing TUPE revisions, and claiming that "[i]f the Government thought of adopting an ostrich-like stance, it was prevented from doing so when [Francovich] was brought to bear"); Celia Weston, Frontiers of Work: Court Puts New Price on Privatised Jobs, Guardian (London), Nov. 10, 1992, at 15 ("The European Commission-in this case prompted by a European Court of Justice decision [Francovich] - has forced the Government to clarify the law on the rights of employees transferred from the public to the private sector, and involved in company buy-outs.").

549. See, e.g., C-29/91, Stichting v. Bartol, 1992 E.C.R. I-3189.

550. The Court entered judgment in November 1991, approximately a year before the introduction of legislation to reform TUPE.

551. See Leslie Christie, Letter, Contracting into Confusion, Guardian (London), Dec. 1, 1992, at 20; Leslie Christie, Contracting for Public Services-Regulations Not Extended for First Time, and Employees' Fears Con'rmed, Fin. Times (London), Nov. 30, 1992, at 15; 
Attorney General reportedly advised ministers of liability risks. ${ }^{552}$ Just as the legislation was about to become effective, an administrative court revived a claim brought by affected employees. ${ }^{553}$

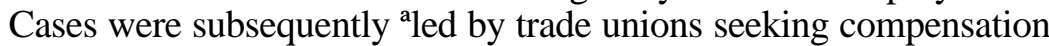
that might run to the "hundreds of millions of pounds." 554

Progress was helped (and hindered) by the Court of Justice's steady stream of judgments in the area ${ }^{55}$ U.K.-induced revisions to

Bruce McKain, Union Goes to Court in Pay Battle, Herald (Glasgow), Jan. 23, 1993, at 5; see also Brian Bercusson, Case Note, 33 Common Mkt. L. Rev. 589, 609 (1996) (noting that "[e]ven before the European Court's judgment, the Trades Union Congress had written to the Government in July 1993 pointing out the failure of the Regulations adequately to transpose the Directive and seeking compensation for those who had suffered").

552. See McLeod, supra note 545, at 14; see also Liza Donaldson, Public Services Management: Not-So-Tender Trap of TUPE, Independent (London), Aug. 1, 1993, at 35; John William \& David Goodhart, Lyell Rejects Ruling on EC Jobs Law, Fin. Times (London), Jan 22,1993 , at 8 . Shortly afterward, liability concerns seem to have in ${ }^{\circ}$ uenced Scotland's largest local authority to implement the directive notwithstanding the pre-amendment state of U.K. law. As local of ${ }^{a}$ cials observed, they had to balance the risks of inviting suits by unsuccessful tenderers for government contracts against the risks of potential compensation to employees, and the latter prevailed. See Graeme Stewart, Scots Breakthrough on Council Workers' Rights, Scotsman, Feb. 3, 1993.

553. See Wren v. Eastbourne Borough Council, 1993 I.C.R. 955, [1993] I.R.L.R. 425 (Emp. App. Trib. 1993).

554. Seumas Milne, Unions Issue 128 Writs Against Government for "Privatised" Workers, Guardian (London), Nov. 30, 1993, at 8. As the Times explained:

Thousands of former public sector employees in this country will be tempted to pursue their case on the ground that they were not adequately represented during the most concentrated period of contracting out in the 1980s. Not all of them, of course, will be able to prove loss to the satisfaction of the courts. The British Government may be spared expensive claims for compensation by the very complexity of the European legal sy stem. But the potential restraint which this ruling will exercise upon future social policy is beyond question.

How Europe Works, Times (London), June 9, 1994; see also Gosling, supra note 543, at 23; Tamara K. Hervey \& Philip Rostani, After Francovich: State Liability and British Emplo yment Law, 25 Indus. L.J. 259, 267-68 (1996); Anne Johnstone, Taken to the Cleaners Over Breach of EU Rules, Herald (Glasgow), June 9, 1994, at 13; Major Setback, Economist, June 11, 1994, at 52; Robert Taylor \& Robert Rice, TUC Welcomes "Devastating Blow", Fin. Times (London), June 9, 1994, at 11; TUPE Or Not TUPE No Longer The Question. It's Time For Settlement-TGWU, Universal News Services, Feb. 3, 1995. By the end of 1997, injoined actions before the High Court involving the interests of at least 1500 workers, the government conceded that workers suffering anancial loss as a result of the commercial venture limitation were entitled to compensation based on Francovich principles. See Frances Gibb, Labour Will Pay for Tory Breach of EU Jobs Law, Times (London), Nov. 18, 1997; 11

King's Bench Walk Chambers, Government Concedes Breach of European Law Obligations in Francovich Claim Brought in Relation to TUPE (visited Oct. 2, 1999) <http://www.11kbw.com>. An earlier case raised, without deciding, the issue of Francovich liability. See National Union of Teachers v. Governing Body of St. Mary's Church of England (Aided) Junior School, [1997] I.C.R. 334, [1997] 3 C.M.L.R. 630 (Ct. App., Civ. Div., 1997) (noting plaintiff's right to elect recovery on basis of vertical direct effect or Francovich, and determination of plaintiff to opt solely for former).

555. See, e.g., Alan Pike \& Robert Rice, Contractors Risk Big Bills after EU Jobs Law Reversal, Fin. Times, Mar. 12, 1997, at 1 (citing assessment by employment lawyers of ECJ decision concerning application of directive to circumstances where contracted-out service transfers from one provider to another as "an amazing U-turn"). 
the directive,${ }^{556}$ domestic political considerations, ${ }^{557}$ and the Commission's persistence. It remains to be seen whether much compensation will actually be paid. ${ }^{558}$ But the results also show the actual and potential in ${ }^{\circ}$ uence of national courts in overcoming government self-interest in evading Community regulatory burdens. On balance, liability appears to have forced the United Kingdom to confront the costs of its non-compliance. It may also have in ${ }^{\circ}$ uenced the subsequent amendments to the directive, which on the whole increased the ${ }^{\circ}$ exibility and options afforded to Member States. ${ }^{559}$

\section{Subsidiarity and Self-Interest: The Rebirth of Discretion}

The suggestion that Francovich is compatible with judicial subsidiarity is perhaps too neat. Indeed, if a rule as intrusive as state liability can be countenanced, it would seem to vindicate the concern of subsidiarity's critics that the principle will be used to expand, rather than contract, the Community's powers. It should be recalled, of course, that subsidiarity analysis does not purport to indicate whether the rule in question is otherwise legally sound; to the contrary, because subsidiarity is an appropriate inquiry only if state liability is not compelled by the Treaty or Community legislation, raising the issue presupposes a discretionary element to the Court's judgment. But it remains that Francovich denies Member States the opportunity to choose a liability regime, and confers authority upon them primarily to enable clashes between national judiciary and the other branches of Member State government.

Closer scrutiny of the Court of Justice's unitary conception of state liability is required. Even if one were to agree with the Court that some principle of state liability is "inherent in the system of the Treaty," 560 it remains vital to question its further conclusion "that

556. The amendments, however, did not alter the issue of contracting-out in any signi ${ }^{\mathrm{a}}$ cant fashion. To the contrary, they expressly recognized that the directive applied to transfers of both private and public ventures. See Council Directive 98/50/EC of 29 June 1998 amending Directive 77/187/EEC on the approximation of the laws of Member States relating to the safeguarding of employees' rights in the event of transfers of undertakings, businesses or parts of businesses, art. 1, 1998 O.J. (L 201) 88.

557. The United Kingdom changed from a Labour Government (which agreed to the drective) to a Conservative Government (which implemented it, and resisted change), and again to a Labour Government (which settled the Article 171 (now art. 234) and Francovich claims).

558. It is notable that even the conciliatory Labour government is requiring individual compensation claims to wind their way through court. See, e.g., Universal News Services, supra note 554 (quoting union of cial's concern that "[c]haos to the year 2000 must be avoided, because the only bene ${ }^{a}$ ciary would be the lawyers, with tens of millions of pounds spent defending the indefensible and building second homes for the bewigged in Marbella").

559. Cf. Jo Hunt, Success at Last? The Amendment of the Acquired Rights Directive, 24 Eur. L. Rev. 215, 228-29 (1999) (attributing new exibility to Community's new approach to social policy).

560. See, e.g., Case C-319/96, Brinkmann Tabakfabriken v. Skatteministeriet, [1998] 3 
that principle holds good for any case in which a Member State breaches Community law." 561 The hallmark of the proportionality inquiry, after all, is to require that the Community rule be no more extensive than is necessary. Just as the compensatory rationale was not equally convincing across contexts, the institutional account may have its limits. It is therefore worth sketching some potentially important limitations to the state liability principle - again, largely with respect to the remedies for the non-implementation of directives, but with potential relevance to the entire remedial spectrum.

\section{Waiver}

One of the few bright lines of the state liability doctrine is Dillenkofer's rule that failures to implement directives automatically constitute serious breaches giving rise to liability. Several other decisions illustrate circumstances that the Court considers as such implementation failures, ${ }^{562}$ though two of them-Miret ${ }^{563}$ and Brinkmann Tabakfabriken ${ }^{564}$-also suggest limits to the per se approach in cases in which Member State failure is consistent with a duty to cooperate under Articles 10 (ex art. 5) and 249 (ex art. 189). ${ }^{565}$ But

C.M.L.R. 673, $683(1998)$

561. See Case C-392/93, Regina v. British Telecommunications, 1996 E.C.R. I-1631, If 38, [1996] 2 C.M.L.R. 217, II 38 (1996)

562. See supra text accompanying notes 490-491.

563. In Miret, decided before the adoption of the "suf ciently serious" threshold for Member State liability, the Court had no difaculty in "nding that the exclusion by Spain of higher management staff from the scope of the employer insolvency directive constituted a basis for liability. But as the Court observed, Spain had the authority to request the exclusion of employee classes via an annex to the directive, and had availed itself of that option with respect to domestic servants; its failure to do so with respect to higher management staff, therefore, might be fairly regarded as more irresponsible than had it merely exercised its prerogatives to de ${ }^{a}$ ne employees under national law. See Case C-334/92, Miret v. Fondo de Garantía Salarial, 1993 E.C.R. I-6911, TII 10-13, [1995] 2 C.M.L.R. 49, ,III 10-13 (1993).

564. In Brinkmann Tabakfabriken, the Netherlands had not taken the necessary legislative measures to adopt an amended Community directive on tobacco taxes, but instead had developed an administrative practice that was inconsistent with the directive. This clearly did not

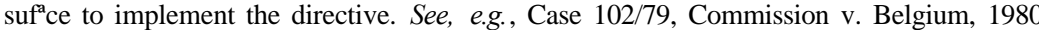
E.C.R. 1473, 1486, [1981] 1 C.M.L.R. 282, 294 (1980) ("Mere administrative practices, which by their nature can be changed as and when the authorities please and which are not publicised widely enough cannot in these circumstances be regarded as a proper fullament [sic] of the obligation imposed by Article 189 ... ."). The Court of Justice recognized that the circumstances would normally call for application of the Dillenkofer rule. Nevertheless, it held that no compensation was in order: there was no link between the untimely implementation and Brinkmann's damages, since the surrogate implementation had in a practical sense given effect to the directive; no other suf ${ }^{a}$ ciently serious breach had been established, since the de nition employed by the government was not "manifestly contrary" to any used in the amending directive, which did not in any event clearly address the tax status of the plaintiff's product. See Case C-319/96, Brinkmann Tabakfabriken GmbH v. Skatteministeriet, [1998] 3 C.M.L.R. 673, IIII 28-33 (1998).

565. One concern, pre-Brinkmann, was that Member States assuming that existing rational law was already consistent with a Community law would automatically be held to have committed a serious breach — rather than being subject to the analysis appropriate to incorrect 
neither seriously undermines Dillenkofer's two more pervasive assumptions - one relating to the priority among Community legishtion, the other concerning the signiacance of timely implementation-that require a more systematic review.

The Court is right in supposing that, all things being equal, every directive should be implemented everywhere in a timely fashion. The potential for state liability, however, attaches only to certain directives, ${ }^{566}$ and it seems inappropriate to privilege them too much over other directives for which liability is less likely to be established or even pursued (such as, for example, environmental directives).567 Any queuing effect from Francovich may not be signiacant-among the host of possible reasons for nonimplementation, taking a back seat in the legislative process to other, liability prone directives probably does not rank especially high - but it may not be negligible in Member States coping with a sizeable number of directives to implement. A more likely result, instead, is hasty implementation. Left with the choice between careful and complete implementation (including, perhaps, resolving a dif ${ }^{a}$ cult, contentious matter of domestic politics) and a shoddy but timely effort, Member States might rationally choose the latter in order to avoid the more demanding Dillenkofer approach to liability, potentially to the disadvantage of the directive's putative bene ${ }^{a}$ ciaries.

The Court is undoubtedly correct to resist pleas by individual Member States for clemency on these or similar bases. These scenarios, however, suggest that there may be valid, good faith considerations why Member States may sometimes desire, as a collective matter, to waive liability. In establishing Francovich as a seemingly unyielding constitutional principle, the Court has called that ability into question. Its assumption, maybe, is that the very power that Member States wield in the Community means that they have acquiesced to the law being enforced. Thus, responding to the arguments by some Member States in Brasserie against a general system of Member State liability, Advocate General Tesauro observed that "it was Member States which, completely freely, agreed on the contractual rules underlying the system as a whole; and Member States are still the decisive protagonists in the process for the for-

implementation of directives, which might be more appropriate in some circumstances. See Tridimas, supra note 193, at 18-19.

566. It is notable, for example, that the decisions to reach the Court of Justice thus far have concerned just a handful of the directives potentially subject to suit-and a number of the cases concern the same directives, such as the employer insolvency directive (both Francovich decisions, as well as Miret) and the package travel directive (both Dillenkofer and Rechberger).

567. See supra note 497 (describing dif ${ }^{a}$ culties in attaching liability in case of environmental directives). 
mulation of Community measures." ${ }^{568}$ Similarly, advocates for $1-$ ability often stress that since Member States exercise decisive control in establishing the underlying instruments, holding them to their terms wreaks no prejudice. ${ }^{569}$

The lack of Member States' agreement on the means of enforcing those contractual rules seems to have been lost in the shuf ${ }^{\circ} .^{570}$ Even if the Court's creation of a state liability principle for their bene ${ }^{a}$ is defensible, Member States may still possess the authority to adapt that principle in the legislative context by amending the Francovich rule through the Community legislation that may occasion its imposition.

A ready example is one addressing the Dillenkofer problem of a complete failure to implement. Although directives are typically enacted with specia ed deadlines for implementation, the Community institutions can choose to set no deadline at all. ${ }^{571}$ Derivatively, the Council has in the past postponed deadlines ${ }^{572}$ and entrusted the Commission to grant additional periods for implementation. ${ }^{573}$ Such authority affects the potential for liability. The Dillenkofer judgment indirectly recognized as much, noting that in the event of delinquent implementation, "the only step ... . available to the Member State concerned is to take the appropriate initiatives within the Community in order to have the competent Community institution grant the necessary extension of the period." 574 The Community institutions should also be able to specify that the failure by a

568. Opinion of Advocate General Tesauro, Cases C-46/93 \& C-48/93, Brasserie $d u$ Pêcheur, 1996 E.C.R. I-1029, II 26, [1996] I.C.M.L.R. 889 (1996).

569. See, e.g. Cary, supra note 476, at 48-51 (noting that activities commonly attributed to "Brussels" in fact marry activities of primarily European institutions with decisions by Member State delegates); Rudolf Dolzer, Subsidiarity: Toward a New Balance Among the European Community and Member States? , 42 St. Louis U. L.J. 529, 531 (1998).

570. State liability itself is volitional only in the weaker, post-hoc sense stressed by neorationalists; that is, that Member States may be deemed to have accepted liability by failing to override the Court's rule.

571. Article 249 (ex art. 189) does not expressly authorize the Community practice of setting deadlines for directives. It may, however, number that as part of the "result" to be achieved, or instead as the "choice of form and methods" otherwise left to Member States. For an example of a directive without deadline, see Directive 80/217, art. 19, 1980 O.J. (L 47) 11 (swine fever); for a general discussion of the deadlines for directives, replete with examples, see Prechal, supra note 43, at 22.

572. See Council Decision 92/10, 1992 O.J. (L 6) 35 (postponing deadline for Directive 89/104 on trademarks, art. 16(2), 1989 O.J. (L 40) 1).

573. See Case C-42/89, Commission v. Belgium, 1990 E.C.R. I-2821, [1990] 1 C.M.L.R. 22 (1990) (discussing post-transposition delays in implementation provided for in Directive $80 / 778$ on drinking water, art. 20, 1980 O.J. (L 229) 11).

574. Cases C-178-79 \& C-188-190/94, Dillenkofer v. Germany, 1996 E.C.R. I-4845, II 54, [1996] 3 C.M.L.R. 469, If 54 (1996) (citations omitted). The Commission also appears to exercise unfettered discretion in its ability to set and grant extensions for complying with its Article 225 (ex art. 169) procedure. See, e.g., Case 125/86, Commission v. Italy, 1987 E.C.R. 4661 (considering Article 169 action brought after Commission granted Italy three extenstions for compliance). 
Member State to adopt a particular directive by the assigned deadline gives rise to a rebuttable presumption of a serious breach or perhaps no presumption at all.

The deeper authority for this power stems from the institutional case for state liability, and its origin and containment by the principle of subsidiarity. The Community may, it is clear, specify the penalties appropriate for enforcement of regulations and directives, subject chie ${ }^{\mathrm{o}} \mathrm{y}$ to the constraints of proportionality and subsidiarity. This is a context-sensitive appraisal requiring a complicated assessment of matters internal and external to the legislation at ssue. ${ }^{575}$ It would be patently inappropriate for the Court to secondguess a legislative judgment on the ground that the penalties contemplated were insuf ${ }^{a}$ cient to enforce a Community norm. Just so, it should equally be available to the legislative institutions to reduce the penalties due Member States for their failures in connection with implementing that legislation. ${ }^{576}$ Failing to provide such an option would not only be inconsistent, but would also impose a Community rule where the legislators may wish to substitute less intrusive Community or even national rules. At a minimum, judicial subsidiarity should not be made to override legislative subsidiarity.

\section{The Role of Third Parties-Public and Private}

The argument for imposing liability on a Member State for nonimplementation may ring hollow when the primary wrongdoer is not a state, but a third party. Where a third party has committed the more immediate (in a causal sense, at least) wrong, it is appealing to permit recovery against that party, perhaps even in lieu of recovery against the Member State.

The most likely culprits are sub-national governments, which are often entrusted by Member States with substantial responsibility for implementing directives. Although they $d o$ object that these assignments mean that state liability may target the wrong actors since in federal systems like Belgium, "regional entities which cannot be coerced are to blame," 577 such objections seem misplaced. It is settled Community law that obligations imposed on Member States are equally imposed on subordinate governments in accordance with the national constitutional order. ${ }^{578}$ Consistent with that

575. See Harding, supra note 102; see also Harding, supra note 461, ch. 2.

576. Alternatively, the Community should be able to enhance the Francovich penalty. For example, the Community could provide that the failure to enact a particular directive by a set time results in the forfeiture of the Member State's agricultural stipend, if doing so is consistent with legislative principles of subsidiarity and proportionality.

577. Harlow, supra note 21, at 209.

578. See, e.g., Case 103/88, Fratelli Costanzo SpA v. Comune di Milano, 1989 E.C.R. 1839, [1989] 3 C.M.L.R. 239 (1990). 
premise, nothing in Francovich prohibits national courts from imposing liability directly on responsible sub-national governments. ${ }^{579}$ Equally important, were liability instead imposed on Member State governments themselves, national governments should be free to seek indemnia ${ }^{\mathrm{a}}$ cation from the responsible regional entities, subject only to domestic limitations.

It is also necessary to consider the role of private third parties, though here, the nature of the directive in question is paramount. Advocate General Mischo anticipated this issue in his Francovich opinion, in which he questioned "whether, within the category of directives which do not give rise to direct effect, a distinction should be made between those whose purpose is to impose obligations on the State and those whose purpose is to impose obligations on private undertakings, there being no liability in the latter case.' As he observed, in the latter case:

[T]he state is being made responsible only for the failure to implement the directive and not for the circumstances which are the direct cause of the harm suffered by the citizen, such as the non-payment of wages, the insuf ${ }^{a}$ cient remuneration of a woman, or the defective nature of a product.

Conversely, where the directive imposes obligations on the State itself (or on an organization which must necessarily be identia ${ }^{a}$ ed with the State), its offence is two-fold: failure to $\mathrm{m}$ plement the directive and failure to comply with the obligations which the directive imposes..$^{580}$

Having proposed the distinction, the Advocate General quickly dismissed it, concluding that "any failure to implement a directive ipso facto constitutes an infringement" that "must be made good by the State where it has caused harm to an individual." 581 That opinion has been echoed by Malcolm Ross, who argues that because "Francovich is an express declaration of a Community law right for individuals," and "inherent" in the Treaty, it is inappropriate to dis-

579. See Coppinger v. Waterford County Council, No. 7109P (Ir. H. Ct. 1986) (LEXIS, Comcas Library, Allcas File) (holding local authority owning and operating truck involved in accident liable in damages for "actionable breach of a directive" that had not been properly implemented at time of accident); see also Noel Travers, The Liability of Local Authorities for Breaches of Community Directives by Member States, 22 Eur. L. Rev. 173 (1997) (discussing Coppinger). Another example may be Lubsen, supra note 535, in which the Dutch Court held not only that the Netherlands was liable for damages resulting from its failure to conform national law to the Equal Treatment Directive, but also that the city of Abcoude was jointly and severally responsible.

580. See Cases C-6/90 \& C-9/90, Francovich v. Italy, 1991 E.C.R. I-5357, II 67, [1993] 2 C.M.L.R. 66, II 67 (1991)

581. Id. at II 68 (emphasis added). 
allow a state liability claim just because an action may be pursued against a third party. 582

This seems unduly hasty. While a Member State may not be the direct cause of the harm in question, its failure to implement in the ${ }^{a}$ rst place and its relative ability to pay and spread losses make a compelling case for permitting suit against it. If one party must make good the wrong suffered by the individual, the Member State is certainly the best positioned. At the same time, a principle imposing dual responsibility on private parties and national governments seems entirely intelligible. ${ }^{583}$ The prospect of liability may encourage third parties to take precautions to diminish the risk of harm-such as, for example, avoiding economic risks, placing consumer deposits in jeopardy (as in Dillenkofer), or procuring wage insurance to address the possibility of insolvency (as in Francovich). It may also diminish the incentives for private parties to exercise political $i^{\circ}$ uence to forestall implementation of directives adversely affecting their interests. ${ }^{584}$ Further, Member States may be less willing to support Community legislation permitting internal delegation and self-regulation if their national governments will in any event bear the risk of liability. ${ }^{585}$

This is not to say, however, that Advocate General Mischo and the Court erred in failing to bifurcate Francovich. An attempt to distinguish directives imposing duties on third parties would almost certainly be hopeless. Given the possible regulatory alternatives offered by some directives, linedrawing prior to Member State election would be dif ${ }^{a}$ cult. For example, the directive at issue in Francovich permitted the state to elect whether to anance entirely the institutions responsible for guaranteeing wages. ${ }^{586}$ It would also

582. See Ross, supra note 25 , at 59 (discussing the potential tradeoff between health and safety-based state liability claims based on improper implementation and actions against employers based on indirect effect).

583. Indeed, it would not be unique to directives. Malcolm Ross describes the potential for dual liability in the case of dominant undertakings, where Member States may incur state liability based on a breach of Article 86(1) (ex art. 90) while the undertakings themselves are exposed to liability under Article 82 (ex art. 86). See Ross, supra note 25, at 62-64. Ross' objections to dual liability under these circumstances overlook its bene ${ }^{\mathrm{a}} \mathrm{ts}$, and are largely addressed by rules preventing double-recovery.

584. It is easy to imagine cases where the potential costs of implementation to private parties-potentially expressed through the political process-signiacantly outweigh the countervailing risk state liability poses to Member States. See, e.g., Case 128/78, Commission v. United Kingdom, 1979 E.C.R. 419, II 7, [1979] 2 C.M.L.R., II 7 (1979) (rejecting excuse by U.K. government that implementing regulation through compulsory measures would meet with active resistance and strikes in the transport sector that would "seriously damage the whole economy of the country"); cf. Anthony Arnull, The Direct Effect of Directives: Grasping the Nettle, 35 Int'l \& Comp. L.Q. 939, 944 \& n.22 (1986).

585. See Elies Steyger, European Community Law and the Self-Regulatory Capacity of Society, 31 J. Common Mkt. Stud. 171, 176 (1993).

586. See Francovich, 1991 E.C.R. I-5357 at IIII 24-26, [1993] 2 C.M.L.R. at III 24-26. 
be difacult to fashion a rule of liability without unsettling the Court's insistence on the absence of horizontal direct effect. One might imagine hybrid rules, in the form of a directive and a regulatory default, that would impose duties on third parties in the event of a Member State's failure to implement on a timely basis. ${ }^{587}$ That would, however, tend to undermine legislative subsidiarity and the primacy of directives. ${ }^{588}$ Alternatively, one might try to capture the distinction without providing for third party liability. For example, where a Member State is clearly the party responsible under the directive, a "serious" breach might be presumed. Such a rule would dovetail nicely with the recurring concerns about Member State self-interest. But it might also risk undermining subsidiarity's values by so complicating the jurisprudence as to disempower the mtional courts.

The most elegant solution would be to let Member States shift liability internally, so as to "pass on" liability (as a matter of national law) to responsible third parties. As critics of government liability note, governments may always pass on costs in the form of taxes. ${ }^{589}$

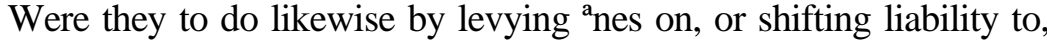
third parties that fail to take adequate precautions to prevent harms deriving from non-implementation, it is by no means clear that the Community could prevent them. As a matter of judicial subsidiarity it would seem inappropriate to interpret state liability or its bases in the Treaty as proscribing this choice. While passing on the costs diminishes a state's purely internal incentives to implement directives, it presumably increases the interests of interest groups in encouraging the implementation-if, indeed, the interest groups have been so ineffective as to permit the government to adopt a practice of liability-shifting. ${ }^{590}$ Absent evidence that such a policy is designed to frustrate, or has the effect of frustrating, a Member State's

587. Analogously, the U.S. Supreme Court has held that where Congress has the authority to regulate private activity under the Commerce Clause, it may, as part of a program of "cooperative federalism," offer States the choice of regulating that activity according to federal standards or having state law pre-empted by federal regulation. See New York v. United States, 505 U.S. 144, 167-68 (1992) (citing examples); Hodel v. Virginia Surface Mining \& Reclamation Ass'n, 452 U.S. 264, 288-89 (1981).

588. See Bermann, supra note 2, at 422 (noting, and rejecting as inconsistent with European subsidiarity, the "New York $v$. United States remedy of 'offer[ing] States the choice of regulating [an] activity according to federal standards or having state law pre-empted by federal regulation"' (alterations in original) (quoting New York v. United States, 505 U.S. at 173)).

589. See Cohen, supra note 453, at 258-60 (government liability fails to promote deterrence because the government can easily shift losses to the general public). Such an argument may have less force in the Community given the advent of EMU and its ${ }^{\text {a }}$ scal restrictions.

590. A further deterrent, presumably, would be the risk of causing the ${ }^{\text {ight }}$ of companies or individuals to Member States that do not adopt such a practice. 
responsibility under Article 249 (ex art. 189), the matter may be left to national law.

The Court took a step in this direction with its recent decision in Konle ${ }^{591}$ in which it held that Member States with federal systems (in that case, Austria) may, consistent with the Treaty, permit ecovery against the sub-national government responsible for the breach. The case concerned a right arising directly under the Treaty, and so the Court did not confront the issue of whether the same approach would be appropriate in a non-implementation case. Its relatively formalistic appraisal, on its face, could be easily transplanted. On the one hand, the Court reasoned, the mere fact that a Member State employs a federal structure does not absolve it from liability. On the other hand, Community law does not require Member States to change their allocation of governmental responsibility, so that in principle a Member State may maintain any procedures permitting the effective protection of Community rights by standards no less favorable than those provided for matters of national law. ${ }^{592}$

Without saying so, Konle evidently balances Member State autonomy and the interest in enforcing Community law rights-and thus cannot be explained in terms of the individual rights focus originally indicated in Francovich. One may safely assume that divided governmental responsibility will decrease, on average, the amenability of federal governments to suits by aggrieved parties, frustrating effective and uniform judicial protection. For reasons previously described, however, a focus on the institutional implic ations of state liability, together with the presumptions dictated by Article 5, may support the Court's conclusion. It is easier to speculate that the prospect of liability will suf ${ }^{a}$ ciently encourage lawful conduct by fragmented governments that cannot easily appropriate the beneats of disobedience, and encourage sub-national governments to in ${ }^{\circ}$ uence the substance of the federal state's conduct at the Community level. Even if that case is not borne out, evaluating the rule through the lens of judicial subsidiarity will at least make transparent an exercise in which the Court is already engaged.

\section{State Liability as Meta-Remedy?}

As previously noted, the Court's state liability jurisprudence $\mathfrak{x}$ commodates the traditional approach to national remedies in at least two different fashions. State liability is in some respects like any other express Community law principle, leaving national law to ${ }^{a} 1$

591. Case C-302/97, Konle v. Republic of Austria, 1999 ECJ CELEX LEXIS 1924 (Eur. Ct. Justice, June 1, 1999).

592. See id. at TII 61-63. 
in the interstices - subject to the usual effectiveness and nondiscrimination principles. ${ }^{593}$ At the same time, the Court indicated in Société Comateb and Sutton that state liability may sometimes provide a complementary remedy where other remedies, like restitution, fail. ${ }^{594}$ In this capacity, state liability is itself interstitial, at least so long as its conditions-including the anding of a serious breach-are satis ${ }^{\mathrm{a}}$ ed. Though primarily hypothetical at this point, each function deserves at least tentative consideration.

Opinions of Advocate General Jacobs illustrate two divergent reactions to the use of state liability as a complementary remedy. In Denkavit Internationaal, the Advocate General resisted an argument for subjecting claims based on Emmott's rule-under which national limitations periods cannot begin to run until a Member State implements the relevant directive - to the same conditions as state liability, and volunteered that the latter was an "exceptional and complementary" remedy that should not be used to circumvent time limits on other remedies against the government. ${ }^{595}$ Following Société Comateb and Sutton, the Advocate General drew on those decisions to explain why circumventing such limits was not so perilous. His opinion in Fantask stressed the different nature of a Iability claim, which was based not merely in "the unjust enrichment of the State resulting from simple error in the routine application of technical legislation," but instead in "a serious violation of individual rights, calling for a reappraisal of the balance between such rights and the collective interest in a measure of legal certainty for the State." 596

The argument presented in Fantask is appealing in many regards. The emphasis on individual rights is important and valid, through the reconciliation of these rights with the "collective interest" seems rather conclusory. ${ }^{597}$ The result may also seem to ${ }^{\circ} \mathrm{Ow}$ ine-

593. See Francovich, 1991 E.C.R. I-5357 at 9III 42-43, [1993] 2 C.M.L.R. at IIII 42-43; see, e.g., Case C-261/95, Palmisani v. INPS, 1997 E.C.R. I-4025, [1997] 3 C.M.L.R. 1356; Case C-373/95, Maso v. INPS, 1997 E.C.R. I-4051, [1997] 3 C.M.L.R. 1244 (1997).

594. See Case C-66/95, The Queen v. Secretary of State for Social Security, ex parte Sutton, 1997 E.C.R. I-2163, [1997] 2 C.M.L.R. 382 (1997) (social security entitlements); Joined Cases C-192 to 218/95, Société Comateb v. Directeur Général des Douanes et Droits Indirects, 1997 E.C.R. I-165, [1997] 2 C.M.L.R. 649 (1997) (trader levies).

595. Opinion of Advocate General Jacobs, Case C-2/94, Denkavit Internationaal v. Kamer van Koophandel en Fabrieken voor Midden-Gelderland, 1996 E.C.R. I-2827, I[80, [1996] 3 C.M.L.R. 504, If 80 (1996).

596. Opinion of Advocate General Jacobs, Case C-18/95, Fantask A/S v. Industriministeriet (Ehrverministeriet), 1997 E.C.R. I-6783, [1998] 1 C.M.L.R. 473, II 83 (1997).

597. For example, the Fantask opinion suggests that state liability will not give "unduly privileged treatment to rights under Community directives," presumably referring to the limits placed on liability by the requirement of a serious breach. Id. at If 84 . It is not entirely clear, however, what the Advocate General would consider undue treatment, or how he would begin to scrutinize the legitimacy of the Member State's claims to have been protecting the collective interest. Similarly, state liability is supposed to provide "comprehensive 
luctably from the nature of Francovich. Employing state liability as a gap- ${ }^{a}$ lling device does subvert national remedial preferences and procedural limitations: in Société Comateb, a rule limiting a trader's recovery of illegal charges to those it has actually borne; in Sutton, a rule permitting recovery of lost entitlements but not interest thereon; in Fantask, hypothetically, ${ }^{598}$ a rule imposing a limitations period on recovery claims. ${ }^{599}$ The intrusion, however, derives amost entirely from the creation of a state liability remedy where there was no such recourse under national law. If state liability is generally consistent with subsidiarity, other remedies, whatever their limitations, may be viewed simply as indications that the conduct was already wrongful under national law.

In fact, many of the arguments in the Fantask opinion translate quite well into the institutional case for state liability. First, a damages regime avoids setting aside national law, thus providing Member States with the option of preserving their entire domestic schemes, so long as they accept the possibility that they may be forced to provide full compensation for any Community rights unduly impaired. ${ }^{600}$ Second, state liability attaches only for suf ${ }^{\mathrm{a}}$ ciently serious breaches, seemingly setting a higher bar for Community intervention, and remains subject to national laws respecting such claims ${ }^{601}$ Finally, state liability provides "a substantial incentive to Member States to implement directives on time and to make every effort to do so properly," and also "encourage[s] them to repair without delay any inadequacies that become apparent, for example because of a ruling of the Court." 602

protection of individual rights within the existing framework of remedies and time limits," which is surely less than comprehensive-and, as noted above, not the existing framework that the Member State had in mind. Id.

598. In its judgment, the Court simply distinguished the Emmott decision without alluding to the possibility of state liability. See id. at III 50-52.

599. See Eeckhout, supra note 189, at 68 ("If the liability remedy could be used concurrently with other national remedies, then in many cases the balance between the rights of the individual and the general interest (and the right of Member States to strike that balance through the adoption of procedural rules) could be lost.").

600. See Opinion of Advocate General Jacobs, Fantask, 1997 E.C.R. at II 84, [1998] 1 C.M.L.R. at 984 (1997). Other supporters of this potential for state liability put the case slightly differently. Eeckhout, for example, notes approvingly that where suf ciently serious breach can be established, state liability may be available not only "to complement other remedies by compensating for damage which cannot be recovered through these remedies," but also "to set aside procedural limitations (such as time-limits) governing other remedies." Eeckhout, supra note 189, at 72. In context, his notion of "setting aside" procedural limits appears to mean precisely what Advocate General Jacobs meant by not setting aside such limits; that is, not literally enjoining or striking them down, but instead permitting compensation notwithstanding the limits germane to other remedies. See id. at 66-73.

601. Opinion of Advocate General Jacobs, Fantask, 1997 E.C.R. at II 84, [1998] 1 C.M.L.R. at II 84 (1997).

602. Id. 
But there are apparent drawbacks as well. The suggestion, for example, that state liability ${ }^{a}$ ts within the "existing framework of remedies and time limits" may be true in some sense, but the important fact is that it is not the framework of the Member State's choosing. Member States, after all, developed procedures for restitution claims, but Francovich would appear to require that they employ state liability rules, which may not have even existed prior to the Court's judgment. So broadening the aeld of state liability, moreover, will undoubtedly lead to additional pressure to harmonize Member State rules relating to its administration. ${ }^{603}$ For example, national rules prioritizing remedies (requiring, perhaps, that avenues for obtaining restitution be exhausted before state liability may be pursued), and rules allocating state liability claims to different courts than those deemed competent to hear other remedies, do not seem facially inconsistent with the deterrence justiacation for state liability, but may well be irresistible targets for integration. ${ }^{604}$

It is very dif ${ }^{a}$ cult to anticipate all implications of such an approach, in part because the questions it presents are so complex. For example, would a plaintiff have to show both that the original grievance constituted a sufaciently serious breach and that the rational law limitation on the basic right to receive damages is itself suf ciently serious to warrant damages? Would the standard for evaluating that latter question be the traditional nondiscrimination and effectiveness principles, or could they instead be invoked to disapply those or other national law limits? Would Member States be better off with disapplication under those principles, or instead embrace state liability as the new meta-remedy for the enforcement of Community law? ${ }^{005}$

Though resolving such questions may prove challenging, they remind us of the margins of judicial subsidiarity. The touchstone of

603. See Eeckhout, supra note 189, at 73 (arguing that potential comprehensiveness of state liability is an additional warrant for ensuring its uniformity).

604. See id . at 70-72 (querying whether the Court would accept exhaustion and jurisdictional rules). Eeckhout also refers to the duty to mitigate damages, considered in Brasserie $d u$ Pêcheur, and suggests that "through the duty to mitigate there is none the less a link between liability actions and other national remedies," such that "many questions may arise." Id. at 70-71. It is not wholly clear what questions those might be. Although he may be right that a duty-to-mitigate defense may also be invoked in relation to a restitution remedy, see id. at 71, notwithstanding the differences stressed by Advocate General Jacobs, see Opinion of Adv ocate General Jacobs, Fantask 1997 E.C.R. at II 82, [1998] 1 C.M.L.R. at 473 II 82, nothing in Brasserie du Pêcheur suggests that it is incumbent upon Member States to afford themselves such a defense against any remedy, state liability or otherwise. Whether the Court would accept a duty-to-mitigate defense in the context of a restitution remedy for the violation of Community law is a question that may be answered entirely independent of the state liability doctrine.

605. Cf. Ross, supra note 25 , at 66 (suggesting that "the failure of national courts to come up with adequate and sufacient remedies under national law for the protection of Community law rights would itself give rise to a claim under Francovich"). 
that inquiry is whether Community intervention is necessary or would demonstrably advance Community interests, particularly the collective interests of Member States. In the case at hand, the virtues are too tentative, or contingent upon the balance of national rules, to comfortably determine the outcome, particularly in light of the potential harm to national arrangements that would ow from recognizing the principle urged by the Advocate General. ${ }^{606}$ The better course at present, it would seem, is simply to permit one or more methods to develop unfettered in the national courts. If a Member State winds up substituting a damages remedy for other Community law remedies, or even for more fundamental standards for evaluating national remedies, Francovich may indeed be considered to have revolutionized European law.

\section{CONCLUSION}

Though Article 5 makes no such distinction, I have focused on the application of judicial subsidiarity in a fundamentally legislative setting - that is, state liability's function as it relates to the nonimplementation of directives. For a variety of reasons, testing judicial subsidiarity in that context is particularly illuminating, and perhaps fruitful as well. As articulated by the Amsterdam Protocol, subsidiarity is concerned with preserving and promoting use of drectives, and it seems appropriate to ensure that the judiciary's approach is not out of sync with Community legislative institutions. Wrestling with judicial subsidiarity in this area is also attractive because of the challenge it presents. Particularly in light of the U.S. norms against commandeering and in favor of state immunity, coupling liability to a legislative device like the directive might seem to add insult to injury, or at least take away discretion purportedly conferred. But liability may in fact help preserve the directive and prevent its conversion into a mere vehicle for commandeering, particularly if the Court heeds the principle of judicial subsidiarity while elaborating the Francovich doctrine.

How far judicial subsidiarity may be applied in other remedial contexts, or in still other areas, is a question for another day. But developing and applying that principle even in a limited fashion has broader virtues, and may provide badly needed proof that the Court can adapt to the Treaty's new paradigms. Once derided as an essentially self-satis ed "constitutional law without politics," ${ }^{607}$ European

606. See Amsterdam Protocol, supra note 16, at 106 II 7.

607. Martin Shapiro, Comparative Law and Comparative Politics, 53 S. Cal. L. Rev. 537, 538 (1980) (arguing that scholarship represented the Community "as a juristic idea; the written constitution as a sacred text; the professional commentary as a legal truth; the case law as the inevitable working out of the correct implications of the constitutional text; and the con- 
legal scholarship increasingly questions the Court's methods and objectives - both as overly integrationist and, from new stakeholders, insuf ${ }^{a}$ ciently protective of human rights - and even invokes subsidiarity to suggest metaphorically that the Court's certaine idée de l'Europe may be just one among many. ${ }^{608}$

Judicial subsidiarity provides the Court with a tool to de ect these diverse criticisms. Most obviously, where decisive, it permits the Court to demonstrate that closely contested cases do not invariably favor Community interests over localism, and to provide a more satisfying explanation than the notion that the Community is not yet ready to prevail. ${ }^{609}$ At the same time, judicial subsidiarity should cause the Court to hone its account of why it is occasionally obliged to craft Community law, and how doing so can bene at the national interests that ostensibly are penalized. If the Court can state its arguments with integrity, it may earn the right to review compliance with subsidiarity by the other Community institutions - and in so doing, go some way toward demonstrating that transparency is not invariably fatal to the exercise of judicial authority.

stitutional court as the disembodied voice of right reason and constitutional teleology"); see also Burley and Mattli, supra note 52, at 45-46 (describing mainstream views of "legalism").

608. See Shaw, supra note 379, at 253.

609. See Bermann, supra note 2, at 394 (noting that in general, "[t]reating subsidiarity as a justiciable principle, whether procedural or substantive, will ... require the Court of Justice to play a role to which it is not accustomed, namely restraining Community action in the interests of localism"). Other applications of judicial subsidiarity, such as to the question of Francovich liability for other Treaty violations, may also challenge the Court's general posture, even if for purely pragmatic reasons. Weiler recently noted, for example, the possibility that U.K. abortion providers could seek damages from Ireland for infringing the Treaty's freedom of movement and freedom of information principles through its restrictive laws on abortion services. See J.H.H. Weiler, Emerging Issues on Compliance and Effectiveness of Community Law, 20 Am. Soc'y Int'1 L., Proc. Ann. Meeting 174 (1997). 